\title{
Combining oxidative coupling and reforming of methane
}

\section{Vision or Utopia?}

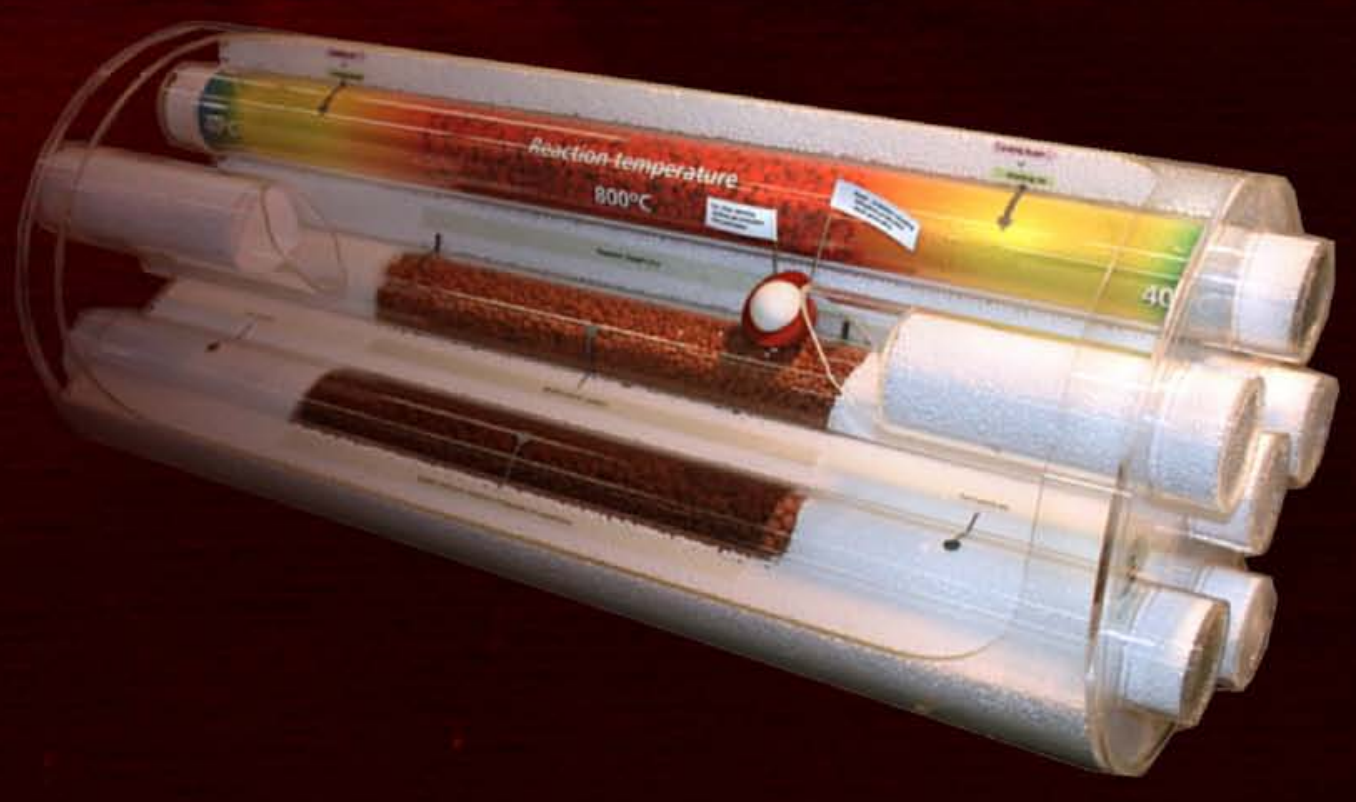

Patrick Graf
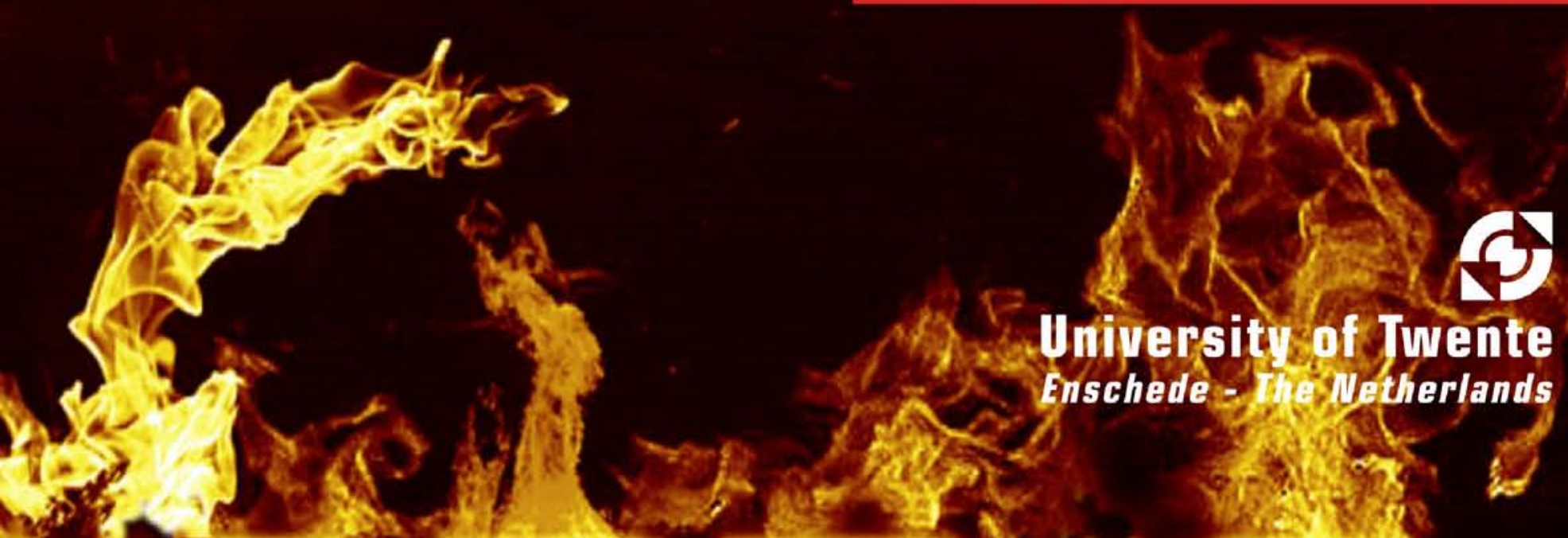
Unipersit sof Jwente Mschede 3 , 4 f therlands 


\title{
Combining oxidative coupling and reforming of methane
}

\author{
Vision or Utopia?
}

Patrick Graf 


\section{Promotie Commissie}

$\begin{array}{lll}\text { Voorzitter: } & \text { Prof.dr. G. van der Steenhoven } & \text { Universiteit Twente } \\ \text { Promotor: } & \text { Prof. dr. ir L. Lefferts } & \text { Universiteit Twente } \\ \text { Assistant promotor: } & \text { Dr. B. L. Mojet } & \text { Universiteit Twente } \\ & \text { Dr. J. G. van Ommen } & \text { Universiteit Twente } \\ \text { Lid: } & \text { Prof.dr.ir. J.A.M. Kuipers } & \text { Universiteit Twente } \\ & \text { Prof.dr.ir. A. Nijmeijer } & \text { Universiteit Twente } \\ & \text { Prof. J.R.H. Ross } & \text { University of Limerick } \\ & \text { Dr. D. van Oeffelen } & \text { Dow Benelux B.V. } \\ & \text { Prof.dr. F. Kapteijn } & \text { Technische Universiteit Delft } \\ & \text { Prof.dr.ir. H. van den Berg } & \text { Universiteit Twente }\end{array}$

The research described in this thesis was performed under the auspices of the Dutch Institute for Research in Catalysis (NIOK). Financial support ACTS-NWO Project No. 053.62.008 (ASPECT) is gratefully acknowledged.

Cover design: Ing. Bert Geerdink, Catalytic Processes and Materials (CPM), University of Twente, Enschede, The Netherlands.

ISBN 978-90-365-2778-1

Copyright (C) 2008 by Patrick Graf, Enschede, The Netherlands

Printed by Gildeprint, Enschede

No part of this book may be reproduced in any form of print, photo print, microfilm or any other means without permission from the author / publisher 


\title{
COMBINING OXIDATIVE COUPLING AND REFORMING OF METHANE
}

\author{
VISION OR UTOPIA?
}

\author{
PROEFSCHRIFT
}

ter verkrijging van

de graad van doctor aan de Universiteit Twente,

op gezag van de rector magnificus, prof. dr. H. Brinksma

volgens besluit van het College voor Promoties

in het openbaar te verdedigen

op vrijdag 23 januari 2009 om 16.45 uur

door

\section{Patrick Oliver Graf}

geboren op 19 augustus 1979

te Aachen 
Dit proefschrift is goedgekeurd door de promotor

\author{
Prof. dr. ir. L. Lefferts
}

En de assitant promotoren

Dr. B. L. Mojet

Dr. J.G. van Ommen 


\section{Contents \\ Inhoudsopgave}

Summary 1

Samenvatting 5

$\begin{array}{lll}\text { Chapter } 1 & 11\end{array}$

Chapter 2 Comparative study of steam reforming of methane, ethane 35 and ethylene on Pt, Rh and Pd supported on yttrium-stabilized zirconia

Chapter 3 Influence of potassium on the competition between methane and ethane in steam reforming over PtYSZ

Chapter 4 The effect of potassium addition to Pt supported on YSZ on

Chapter 5 Reactive separation of ethylene from the effluent gas of methane oxidative coupling via alkylation of benzene to ethylbenzene on ZSM-5

Chapter 6 New insights in the water gas shift mechanism on $\mathrm{Pt} / \mathrm{ZrO}_{2}$ : the role of hydroxyl groups elucidated

Chapter $7 \quad$ Conclusions

Dankwoord

Publications

Curriculum Vitae 



\section{Summary}

Methane, which is the principal component of natural gas reserves, is currently being used for home and industrial heating and for the generation of electrical power. In many aspects methane is an ideal fuel because of its availability in most populated centres, its ease of purification and the fact that is has the largest heat of combustion compared to the amount of $\mathrm{CO}_{2}$ formed, among all hydrocarbons. On the other hand, methane is an under-utilised resource for chemicals and liquid fuels. Known resources of natural gas are enormous and rival those of liquid petroleum. Moreover, the known reserves of methane are increasing more rapidly than those of liquid petroleum.

Large amounts of methane are found in regions that are located far away from industrial complexes and often methane is found off shore. This means its transportation is uneconomical or even impossible. Transportation problems and the increasing oil price have led to world-wide efforts for directly converting methane into easy transportable value added products, such as ethylene (feedstock for petrochemicals), aromatics and liquid hydrocarbon fuels. The main goal of the work described in this thesis was the development of an auto thermal process, combining the exothermic oxidative coupling of methane (1) and highly exothermic combustion (side)reactions (2) with the endothermic processes of methane steam reforming (3) and methane dry reforming (4). The desired products are ethylene and synthesis gas. 


$$
\begin{aligned}
& \mathrm{CH}_{4}+1 / 2 \mathrm{O}_{2} \rightarrow 1 / 2 \mathrm{C}_{2} \mathrm{H}_{4}+\mathrm{H}_{2} \mathrm{O} \quad \Delta \mathrm{H}^{\circ}{ }_{298} \quad=-140 \mathrm{~kJ} / \mathrm{mol} \\
& \mathrm{CH}_{4}+2 \mathrm{O}_{2} \rightarrow \mathrm{CO}_{2}+2 \mathrm{H}_{2} \mathrm{O} \quad \Delta \mathrm{H}^{\circ}{ }_{298}=-801 \mathrm{~kJ} / \mathrm{mol} \\
& \mathrm{CH}_{4}+\mathrm{H}_{2} \mathrm{O} \rightarrow 3 \mathrm{H}_{2}+\mathrm{CO} \quad \Delta \mathrm{H}^{\circ}{ }_{298}=206 \mathrm{~kJ} / \mathrm{mol} \\
& \mathrm{CH}_{4}+\mathrm{CO}_{2} \rightarrow 2 \mathrm{H}_{2}+2 \mathrm{CO} \quad \Delta \mathrm{H}^{\circ}{ }_{298}=247 \mathrm{~kJ} / \mathrm{mol}
\end{aligned}
$$

The research discussed in this thesis and the parallel work by Tymen Tiemersma evaluated the possibilities of combining the oxidative coupling and reforming of methane in one multifunctional reactor. Several aspects related to catalyst and reactor development were investigated and are described in the two $\mathrm{PhD}$ theses.

Chapter 2 discusses a comparative study of methane, ethane and ethylene steam reforming on $\mathrm{Pt}, \mathrm{Rh}$ and $\mathrm{Pd}$ on YSZ (yttrium-stabilized zirconia). The intention was to develop a methane selective steam reforming catalyst, showing low reactivity towards ethane and ethylene. Both reactivity and composition of products varied depending on the reforming catalyst. The order of activity of separate hydrocarbons on $\mathrm{Rh}$ was $\mathrm{C}_{2} \mathrm{H}_{6}$ $>\mathrm{C}_{2} \mathrm{H}_{4}>\mathrm{CH}_{4}$. On Pt, methane reacted faster than the $\mathrm{C} 2$ hydrocarbons: $\mathrm{CH}_{4}>\mathrm{C}_{2} \mathrm{H}_{6}$ $\approx \mathrm{C}_{2} \mathrm{H}_{4}$. Concerning the target process of methane coupling combined with reforming, $\mathrm{Pt}$ is considered the most promising metal because $\mathrm{C} 2$ hydrocarbons are converted less than methane. Additionally, Pt/YSZ was the most stable catalyst. On Pt/YSZ, the steam reforming reactions resulted in synthesis gas exclusively. It was shown that on $\mathrm{Rh} / \mathrm{YSZ}$, additionally to synthesis gas, methane was formed during steam reforming of ethane on Rh/YSZ. Hydrogenolysis of ethane occurred on this catalyst as a consecutive reaction, converting hydrogen produced in ethane steam reforming and unconverted ethane via hydrogenolysis to methane. This showed that effective steam reforming of higher hydrocarbons can only be achieved when the activity for hydrogenolysis is limited, avoiding production of methane.

Chapter 3 and 4 discuss the potassium modification of $\mathrm{Pt}$ supported on Yttrium stabilized zirconia. Reforming experiments with mixtures of methane/ethylene showed that preferential conversion of ethylene occurred on PtYSZ. It was also found that in methane/ethane mixtures, methane and ethane competed for active sites on Pt. It was found that ethane provides a high surface coverage of $\mathrm{C}_{\mathrm{x}} \mathrm{H}_{\mathrm{y}}$ fragments and that 
in mixtures of methane and ethane on PtYSZ, water activation is the rate limiting step. The addition of potassium to PtYSZ resulted in a weaker adsorption of methane and ethane on the Pt surface, indicated by weakened adsorption of CO in FT-IR TPD on Pt4K700. With potassium addition the hydrocarbon activation on Pt became rate determining for mixtures of methane and ethane, induced by low surface coverage of methane and ethane in this case. As a result, competition effects of methane and ethane were diminished on potassium modified PtYSZ, enabling simultaneous conversion of methane and ethane. Unfortunately, ethane conversion is not suppressed by the addition of potassium. A catalyst that clearly suppresses ethane conversion would be needed to make the overall concept of oxidative coupling combined with steam reforming applicable in one reactor compartment. In conclusion, it can be said that it is unlikely that a methane selective catalyst for the steam reforming process can be developed.

Chapter 5 discusses the separation of ethylene from the effluent gas of oxidative coupling, which has been a challenging issue for several years. Separation of ethylene is necessary between oxidative coupling and reforming processes to avoid ethylene conversion to synthesis gas in the steam reforming process. Reactive separation of ethylene, via alkylation of benzene to ethylbenzene (EB) is a promising option in comparison to earlier proposed concepts like cryogenic distillation. Ethylene was successfully converted to the useful chemical intermediate ethylbenzene using ZSM5. Yields of EB up to $90 \%$ were found at above $95 \%$ conversion and more than $90 \%$ selectivity at $360^{\circ} \mathrm{C}$. None of the additional components present in the effluent gas of oxidative coupling $\left(\mathrm{CO}, \mathrm{CO}_{2}, \mathrm{CH}_{4}, \mathrm{C}_{2} \mathrm{H}_{6}\right.$ and $\left.\mathrm{H}_{2} \mathrm{O}\right)$ influences activity or selectivity of the alkylation catalyst. Stability of ZSM-5 is also not influenced by the added components, with the exception of water, which even increases stability.

The activation of water on zirconia was investigated in Chapter 6, using water gas shift as a model reaction. The water gas shift reaction converts water and $\mathrm{CO}$ to $\mathrm{CO}_{2}$ and hydrogen. It was shown that water induces the presence of two types of hydroxyl groups on monoclinic zirconia: mono- and multi-coordinated hydroxyls. Both types are active in the water gas shift mechanism, but they have different functionalities, as demonstrated on a $\mathrm{PtZrO}_{2}$ catalyst. Mono coordinated hydroxyls are involved in reaction with $\mathrm{CO}$ to the intermediate formate, while multi coordinated hydroxyls play 
a role in formate decomposition. Platinum was not necessary for formate formation and is suggested only to play a role in formate decomposition/product formation. The reaction products, $\mathrm{CO}_{2}$ and $\mathrm{H}_{2}$ were formed on $\mathrm{Pt} / \mathrm{ZrO}_{2}$ when subjected to $\mathrm{CO}$, even in the absence of water. However, without water product formation was temporary. Subsequent treatment with water regenerated the hydroxyls on the $\mathrm{ZrO}_{2}$ support. Continuous production of $\mathrm{CO}_{2}$ and $\mathrm{H}_{2}$ was observed in presence of water. These observations led to the conclusion that the role of water in the process is to regenerate the catalyst and avoid depletion of hydroxyl groups. The mechanistic insights gained in this study provide new possibilities to improve water gas shift catalysts by optimizing the availability of mono- and multi-coordinated groups on the support.

In chapter 7 , results from previous chapters are summarized and translated into ideas for possible reactor concepts for the combined process of oxidative coupling and reforming of methane. Because of the high reforming activity of ethane and ethylene, contact between $\mathrm{C} 2$ hydrocarbons and the reforming catalyst should be avoided. This led to two proposed concepts for future research: The first concept combines oxidative coupling and reforming in structured spherical catalyst particles, consisting of an outer layer of oxidative coupling catalyst and a core of a reforming catalyst. Essential challenges in this concept are optimising the diffusion of methane and steam to the center of the particle and limiting the combustion of ethylene on the oxidative coupling catalyst in the last part of the reactor. The second concept combines oxidative coupling and reforming in different reactor compartments, still facilitating heat exchange between both processes. After oxidative coupling, reactive separation of ethylene by alkylation with benzene is performed. The remaining mixture is fed to the reforming compartment of the reactor, yielding synthesis gas. The total process will convert methane, oxygen and benzene to synthesis gas and ethylbenzene. Efficient heat exchange between reactant and product streams is needed to make this concept feasible. Experimental demonstration of both concepts offers a challenging task for future research. 


\section{Samenvatting}

Methaan, de hoofdcomponent in aardgas, wordt momenteel vooral gebruikt voor verwarming in particuliere en industriële toepassingen en voor het opwekken van elektriciteit. Methaan is een ideale brandstof door beschikbaarheid in dicht bevolkte gebieden, door de eenvoudige zuivering en de hoge verbrandingswaarde vergeleken bij de $\mathrm{CO}_{2}$ uitstoot. Methaan zou in de toekomst een belangrijke grondstof voor chemicaliën en vloeibare brandstoffen kunnen vormen. De beschikbare aardgasreserves zijn enorm en vergelijkbaar met de ruwe olie reserves. Sterker nog, steeds meer nieuwe aardgas voorraden worden ontdekt, terwijl voor ruwe olie de prijs stijgt en de beschikbaarheid niet toeneemt.

Grote hoeveelheden additioneel methaan zijn te vinden in ver afgelegen gebieden, op grote afstand van industriële complexen en vaak zelfs in zeegebieden. Dit betekent dat transport van aardgas vaak niet economisch rendabel of zelfs onmogelijk is. Deze transportproblemen hebben geleid tot wereldwijde onderzoeksinitiatieven om aardgas om te zetten naar hoogwaardige en efficiënt te vervoeren producten, bijvoorbeeld etheen, aromatische verbindingen en vloeibare brandstoffen. De doelstelling van het werk in dit proefschrift was de ontwikkeling van een autotherm en dus energie efficiënt proces, waarbij de exotherme oxidatieve koppeling van methaan (1) en de zeer exotherme verbrandingsreacties (2) gecombineerd worden met de endotherme steam (3) en dry (4) reforming van methaan. De gewenste producten hierbij zijn etheen en synthesegas $\left(\mathrm{H}_{2}+\mathrm{CO}\right)$. 


$$
\begin{array}{lll}
\mathrm{CH}_{4}+1 / 2 \mathrm{O}_{2} \rightarrow 1 / 2 \mathrm{C}_{2} \mathrm{H}_{4}+\mathrm{H}_{2} \mathrm{O} & \Delta \mathrm{H}^{\circ}{ }_{298} & =-140 \mathrm{~kJ} / \mathrm{mol} \\
\mathrm{CH}_{4}+2 \mathrm{O}_{2} \rightarrow \mathrm{CO}_{2}+2 \mathrm{H}_{2} \mathrm{O} & \Delta \mathrm{H}^{\circ}{ }_{298} & =-801 \mathrm{~kJ} / \mathrm{mol} \\
\mathrm{CH}_{4}+\mathrm{H}_{2} \mathrm{O} \rightarrow 3 \mathrm{H}_{2}+\mathrm{CO} & \Delta \mathrm{H}^{\circ}{ }_{298}=206 \mathrm{~kJ} / \mathrm{mol} \\
\mathrm{CH}_{4}+\mathrm{CO}_{2} \rightarrow 2 \mathrm{H}_{2}+2 \mathrm{CO} & \Delta \mathrm{H}^{\circ}{ }_{298}=247 \mathrm{~kJ} / \mathrm{mol}
\end{array}
$$

In samenwerking met Tymen Tiemersma zijn in dit project de mogelijkheden tot combinatie van oxidatieve koppeling en reforming van methaan in een multifunctionele reactor geëvalueerd. Hierbij stond de ontwikkeling van efficiënte katalysatoren voor beide processen en het ontwerpen van een geschikt reactorconcept centraal.

In hoofdstuk 2 wordt de reforming activiteit van methaan, ethaan en etheen op Pt, $\mathrm{Rh}$ en Pd katalysatoren vergeleken. Alle metalen werden op een drager van yttriumgestabiliseerd zirconia (YSZ) getest. De vraagstelling hierbij was of een katalysator gevonden kan worden die selectief methaan omzet en tegelijkertijd een lage reactiviteit t.o.v. ethaan en etheen vertoont. Afhankelijk van de gebruikte katalysator zijn grote verschillen tussen de metalen gevonden, zowel op het gebied van reactiviteit als wat betreft productsamenstelling. The activiteit van de separaat gevoede koolwaterstoffen in steam reforming op RhYSZ was $\mathrm{C}_{2} \mathrm{H}_{6}>\mathrm{C}_{2} \mathrm{H}_{4}>\mathrm{CH}_{4}$. Op PtYSZ reageerde methaan sneller dan de C2-koolwaterstoffen: $\mathrm{CH}_{4}>\mathrm{C}_{2} \mathrm{H}_{6} \approx \mathrm{C}_{2} \mathrm{H}_{4}$. Daarnaast was PtYSZ de meest stabiele katalysator in de testen. Om deze redenen werd Pt geselecteerd als meest geschikte metaal voor verder onderzoek. Opvallend was de vorming van methaan naast synthese gas op RhYSZ bij steam reforming van ethaan, terwijl op PtYSZ uitsluitend synthese gas geproduceerd werd. De methaanvorming op RhYSZ werd toegeschreven aan hydrogenolyse van ethaan, waarbij ethaan met in steam reforming geproduceerde waterstof wordt omgezet naar methaan. Dit laat zien dat de hydrogenolyse activiteit van een steam reforming katalysator beperkt moet worden om te voorkomen dat ethaan naar methaan kan terugreageren.

In hoofdstuk 3 en 4 wordt kalium modificatie van PtYSZ besproken. Op ongemodificeerd PtYSZ bleek in mengsels van etheen/methaan voornamelijk etheen 
omgezet te worden. In mengsels van ethaan/methaan werd competitieve conversie tussen ethaan en methaan gevonden. De toevoeging van kalium aan PtYSZ had een significant effect op de steam reforming van ethaan/methaan mengsels. De adsorptiesterkte van de koolwaterstoffen werd verzwakt. Door de resulterende lage bedekkingsgraden van methaan en ethaan werd het competitie-effect in steam reforming opgeheven. Hierdoor werd gelijktijdige omzetting van beide koolwaterstoffen mogelijk. De conversie van ethaan werd echter niet onderdrukt door de toevoeging van kalium aan de katalysator. Een katalysator met duidelijke onderdrukking van de ethaanconversie zou voor de toepassing van het totaalconcept van oxidatieve koppeling en steam reforming in een reactorbuis nodig zijn. Uit de uitgevoerde experimenten werd de conclusie getrokken dat het onwaarschijnlijk is dat een compleet methaan selectieve reforming katalysator ontwikkeld kan worden.

In hoofdstuk 5 wordt de scheiding van etheen uit het productmengsel van de oxidatieve koppeling onderzocht, welke al verschillende jaren een grote uitdaging vormt. Afscheiding van etheen is noodzakelijk tussen oxidatieve koppeling en reforming, om etheenomzetting naar synthesegas in het reforming proces te voorkomen. Voor deze scheiding is alkylering van benzeen met etheen naar ethylbenzeen een veelbelovende optie, vergeleken met bijvoorbeeld de eerder onderzochte cryogene destillatie. Experimenteel werd etheen over een ZSM-5 zeoliet omgezet naar ethylbenzeen met een opbrengst tot $90 \%$, waarbij de selectiviteit en conversie respectievelijk boven de $95 \%$ en $90 \%$ lagen. Methaan en ethaan in de voeding werden hierbij niet omgezet en kunnen voor steam reforming gebruikt worden in het totaalproces. Alle componenten in de productstroom van oxidatieve koppeling $\left(\mathrm{CO}_{2}, \mathrm{CO}\right.$ en water, ethaan en methaan) hadden geen invloed op de selectiviteit en activiteit van ZSM-5. De componenten hadden ook geen invloed op de stabiliteit, met uitzondering van water dat zelfs voor een verhoogde stabiliteit van de katalysator zorgde.

De activering van water op zirconia wordt in hoofdstuk 6 besproken aan de hand van de water gas shift reactie, die $\mathrm{CO}$ en water omzet naar waterstof en $\mathrm{CO}_{2}$. Water kan op zirconia twee types hydroxyl groepen vormen: mono en multi gecoordineerde hydroxylgroepen. Beide zijn actief in het water gas shift proces maar hebben verschillende functies in het mechanisme, zoals werd aangetoond op een $\mathrm{PtZrO}_{2}$ 
katalysator. De mono groepen op zirconia reageren met $\mathrm{CO}$ naar een formaatcomplex, dat als intermediair van de reactie beschouwd kan worden. Multi gecoördineerde hydroxylgroepen zijn betrokken bij de ontleding van het formaat complex. Er werd aangetoond dat Pt niet nodig is bij het vormen van het formaat maar wel een belangrijke rol speelt bij de formaatontleding naar de gasfase producten $\mathrm{H}_{2}$ en $\mathrm{CO}_{2}$. Op $\mathrm{PtZrO}_{2}$ kon door pulsen van $\mathrm{CO}$ de reactie tijdelijk plaatsvinden, zelfs in afwezigheid van water. De tijdelijke productie van waterstof en $\mathrm{CO}_{2}$ stopte met de uitputting van de hydroxyl groepen op het zirconia oppervlak. Omdat na waterbehandeling weer tijdelijke reactie mogelijk was en de reactie in aanwezigheid van water continu verliep, werd geconcludeerd dat de rol van het water in het mechanisme bestaat uit het regenereren van hydroxyl groepen. De nieuwe mechanistische inzichten leiden tot de conclusie dat het optimaliseren van de aanwezigheid van mono en multi gecoördineerde hydroxylgroepen essentieel is voor een goede water gas shift katalysator.

In hoofdstuk 7 worden de belangrijkste resultaten uit de vorige hoofdstukken samengevat en naar ideeën voor mogelijke reactorconcepten voor een gecombineerd proces van oxidatieve koppeling en reforming van methaan vertaald. Contact tussen ethaan en etheen met de reforming katalysator moet hierbij vermeden worden, gezien de hoge reforming activiteit van beide koolwaterstoffen. Uiteindelijk worden twee reactorconcepten gepresenteerd waarvaan de haalbaarheid in verder onderzoek in detail bekeken kan worden. Het eerste concept combineert oxidatieve koppeling en reforming in een multifunctioneel katalysatordeeltje. Het deeltje is opgebouwd uit een katalysatorlaag voor oxidatieve koppeling aan de buitenkant en een reforming katalysator in de kern van het bolvormige katalysatordeeltje. Een optimale diffusie van methaan en stoom naar de reforming kern van het deeltje en de beperking van de etheen en ethaan verbranding aan de buitenkant op de oxidatieve koppelingskatalysator in de het laatste deel van het katalysatorbed zijn de belangrijkste uitdagingen in dit concept. Het tweede concept combineert oxidatieve koppeling en reforming in verschillende reactor compartimenten, waarbij warmteuitwisseling tussen beide processen nog steeds voor een autotherm proces zorgt. $\mathrm{Na}$ de oxidatieve koppeling wordt etheen reactief uit de productstroom afgescheiden door alkylering van benzeen naar ethylbenzeen. Het resterende mengsel wordt vervolgens 
naar het reforming proces geleid en omgezet naar synthesegas. Uiteindelijk worden in dit proces methaan, benzeen en zuurstof naar synthesegas en ethylbenzeen omgezet. Efficiënte warmteoverdracht tussen reactant- en productstromen vormt de grootste uitdaging in het tweede concept. De experimentele demonstratie van beide concepten biedt interessante mogelijkheden voor toekomstig onderzoek. 



\section{Chapter 1}

\section{Introduction}

\subsection{Introduction}

Methane, which is the principal component of natural gas reserves, is currently being used for home and industrial heating and for the generation of electrical power. In many aspects methane is an ideal fuel because of the existence of distribution systems in most populated centres, its ease of purification and the fact that is has the largest heat of combustion compared to the amount of $\mathrm{CO}_{2}$ formed, among all hydrocarbons. On the other hand, methane is an under-utilised resource for chemicals and liquid fuels. Known resources of natural gas are enormous and rival those of liquid petroleum. Moreover, the known reserves of methane are increasing more rapidly than those of liquid petroleum and it is expected that this trend will extend into the $21^{\text {st }}$ century [1].

Large amounts of methane are found in regions that are located far away from industrial complexes and often methane is found off shore. This means its transportation is uneconomical or even impossible. Parts of the methane obtained, is re-injected, flared or vented at the moment, which is waste of hydrocarbon resource. Both methane and $\mathrm{CO}_{2}$ are greenhouse gases responsible for global warming and more strict regulations about letting out or flaring are expected in the future.

These transportation and environmental problems and the increasing oil price have led to world-wide efforts for directly converting methane into easy transportable value 
added products, such as ethylene (feedstock for petrochemicals), aromatics and liquid hydrocarbon fuels.

Direct and indirect methods are known for methane valorisation. The indirect routes are based on partial oxidation. The most used reaction is the highly energy consuming steam reforming to produce synthesis gas $\left(\mathrm{CO}\right.$ and $\left.\mathrm{H}_{2}\right)$. The synthesis gas is converted either to liquid fuels through Fischer Tropsch or to methanol and subsequently to olefins or gasoline. These two or three steps processes require high investments in production plants. Considerable efforts have been made for many years to develop direct conversion reactions producing partially oxidised compounds (mainly methanol) and products derived from oxidative coupling of methane (ethane and ethylene).

The main goal of the work described in this thesis is the development of an auto thermal process, combining the exothermic oxidative coupling of methane and highly exothermic combustion (side)reactions with the endothermic processes of methane steam reforming and methane dry reforming in a new multifunctional reactor. The intention is to convert the combustion products of the OCM reaction, e.g. $\mathrm{CO}_{2}$ and $\mathrm{H}_{2} \mathrm{O}$, to $\mathrm{CO}$ and hydrogen via reforming reactions with remaining methane. By integrated catalyst and reactor development the activity for the oxidative coupling and reforming will be optimised. In this first chapter a literature overview of oxidative coupling and reforming of methane and higher hydrocarbons will be given. Topics like catalysts formulations and process conditions will be discussed. 


\subsection{Oxidative coupling of methane}

\subsubsection{Introduction and challenges}

The major difficulty of oxidative coupling of methane (OCM) is to overcome the energy barrier of the strong first $\mathrm{C}-\mathrm{H}$ bond in methane $\left(435 \mathrm{~kJ} \mathrm{~mol}^{-1}\right)$. This implies that coupling reactions have to be carried out at high temperatures (more than $700^{\circ} \mathrm{C}$ ), leading to the following challenges $[2,3]$ :

- Occurrence of homogeneous gas phase reactions, giving a complex pattern of parallel reactions

- Kinetic stabilization of the products could be a problem, because of consecutive reactions. As ethylene is more reactive than methane high selectivity can only be obtained at low conversions

- Presence of mass transfer limitations can influence the catalytic reactions

- The process requires a catalyst with high thermal and hydrothermal stability. The evaporation of volatile/low melting catalytically active components or chemical interactions with the support may lead to catalyst deactivation.

- When a high $\mathrm{CH}_{4} / \mathrm{O}_{2}$ ratio is used in the process, the selectivity for $\mathrm{C}_{2}$-hydrocarbons is high but the methane conversion is low. At lower $\mathrm{CH}_{4} / \mathrm{O}_{2}$ ratios, a lower selectivity is obtained. This also leads to a more exothermic and hazardous process, due to occurrence of combustion reactions at a larger extent. Also the process is less efficient, due to low selectivity

- The low ethylene concentrations in the product stream lead to high separation cost. Cryogenic distillation has been considered for separation, operating around $-160^{\circ} \mathrm{C}[4,5]$. This implies a large temperature difference between oxidative coupling and separation.

- Due to low yield a large methane recycle will be required in the oxidative coupling process 


\subsubsection{Reaction mechanism}

In the OCM process the following reactions occur simultaneously [3]:

$$
\begin{aligned}
& 2 \mathrm{CH}_{4}+0.5 \mathrm{O}_{2} \rightarrow \mathrm{C}_{2} \mathrm{H}_{6}+\mathrm{H}_{2} \mathrm{O} \\
& \mathrm{C}_{2} \mathrm{H}_{6}+0.5 \mathrm{O}_{2} \rightarrow \mathrm{C}_{2} \mathrm{H}_{4}+\mathrm{H}_{2} \mathrm{O} \\
& \mathrm{C}_{2} \mathrm{H}_{6} \rightarrow \mathrm{C}_{2} \mathrm{H}_{4}+\mathrm{H}_{2} \\
& \mathrm{CH}_{4}+2 \mathrm{O}_{2} \rightarrow \mathrm{CO}_{2}+2 \mathrm{H}_{2} \mathrm{O} \\
& \mathrm{CH}_{4}+1.5 \mathrm{O}_{2} \rightarrow \mathrm{CO}+2 \mathrm{H}_{2} \mathrm{O} \\
& \mathrm{C}_{2} \mathrm{H}_{6}, \mathrm{C}_{2} \mathrm{H}_{4}, \mathrm{H}_{2}+\mathrm{O}_{2} \rightarrow \mathrm{CO}, \mathrm{CO}_{2} \text { and water }
\end{aligned}
$$

The reactions indicate that in a first step the coupling to ethane takes place (1). Ethylene can be produced by dehydrogenation of ethane (3). Oxidative dehydrogenation to ethylene is also possible (reaction 2), but occurs at a much slower rate [4]. Reactions (4) and (5) show the side combustion reactions of methane, while equation (6) indicates combustion reactions of the products. It should be noted that the oxidative coupling reactions (1) \& (2) are slightly exothermic and the combustion reactions (3), (4) \& (5) are highly exothermic, leading to excessive heat formation in the oxidative coupling process.

Even if the gas-phase reactions play an important role in the overall process, the presence of a catalyst is essential. According to different sources [2, 3, 6, 7] methane dehydrogenates on the catalyst surface and produces methyl radicals, which can react on the surface or in the gas phase. The abstraction of a hydrogen atom is caused by an oxygen ion present on the surface of the catalyst. Next to the efficient formation of methyl radicals, coupling of the radicals is also essential. It is generally accepted that coupling of $\mathrm{CH}_{3} \bullet$-radicals takes place in gas phase [3]. Several catalyst systems and reactor configurations have been used and a short overview will be given in the next paragraphs.

\subsubsection{Performance of various catalysts}

A large number of catalysts with or without support have been evaluated for their performance in the OCM process with the objective of developing a highly selective, active and stable catalyst $[1-3,6,8-26]$. Comparison of catalysts is not straight 
forward as different conditions and reactor configurations were used in the different studies presented. Among experimental conditions temperature, feed compositions and space velocity (contact time) were the main variables. Furthermore fixed bed reactors of different sizes (ranging from micro reactors to scale up tubes) and various other reactor types (different membrane reactors, solid electrolyte or gas recycle) were used. In Table 1.1 gives an overview of the best catalysts, concerning C2(+)-yield, selectivity, stability and experimental conditions:

The $\mathrm{Mn} / \mathrm{Na}_{2} \mathrm{WO}_{4} / \mathrm{SiO}_{2}$ system was an excellent catalyst in terms of both stability and activity. It was also called the most effective catalyst in a review by Lunsford [27]. Other systems that have approximately the same activity show stability problems or stability has not been investigated.

Table 1.1: Comparison of the best OCM catalysts: conditions, performance and stability

\begin{tabular}{|l|c|c|c|c|c|}
\hline catalyst & $\begin{array}{c}\text { Temp } \\
\left({ }^{\circ} \mathbf{C}\right)\end{array}$ & $\begin{array}{c}\text { Ratio } \\
\mathbf{C H}_{4}: \mathbf{O}_{2}: \mathbf{H e}\end{array}$ & $\begin{array}{c}\text { C2+-yield } \\
(\mathbf{\%})\end{array}$ & $\begin{array}{c}\text { Selectivity } \\
(\boldsymbol{\%})\end{array}$ & $\begin{array}{c}\text { Stability } \\
(\mathbf{h})\end{array}$ \\
\hline $\mathrm{Eu}_{2} \mathrm{O}_{3}[12]$ & 725 & $6.7: 1: 0$ & 17.7 & 72.4 & $?$ \\
\hline $\mathrm{Ce} / \mathrm{La}_{2} \mathrm{O}_{3}[12]$ & 775 & $4-5: 1: 0$ & 22.3 & 66.0 & $?$ \\
\hline $\mathrm{Li} / \mathrm{MgO}[3]$ & 750 & $4: 1: 0$ & $+/-19$ & 65 & up to 100 \\
\hline $\mathrm{La}-\mathrm{Ce} / \mathrm{MgO}[12]$ & 850 & $4-5: 1: 0$ & 16.1 & 72.4 & high* \\
\hline $\mathrm{Mn} / \mathrm{Na}_{2} \mathrm{WO}_{4} / \mathrm{SiO}_{2}[6,16,21-23]$ & $800 / 850$ & various & $20-26$ & 80 & $>100$ \\
\hline $\mathrm{Mn} / \mathrm{K}_{2} \mathrm{WO}_{4} / \mathrm{SiO}_{2}[16]$ & 800 & $3.2: 1: 0$ & 18.5 & 62.4 & $>5$ \\
\hline $\mathrm{Mn} / \mathrm{Na}_{2} \mathrm{WO}_{4} / \mathrm{MgO}[6,22]$ & 800 & $7.4: 1: 0$ & 20 & 75 & 40 \\
\hline $\mathrm{Na} / \mathrm{S} / \mathrm{P} / \mathrm{Zr} / \mathrm{Mn}[14,15]$ & 790 & $3: 1: 0$ & 27.8 & 73.5 & $>10$ \\
\hline
\end{tabular}

*stability was only reported for $\mathrm{La} / \mathrm{MgO}$ and $>100$ hours

The multi component system by Huang [13, 14] shows questionable stability as experiments were only carried out for about 10 hours. The maximum yield of $27.8 \%$ in single pass packed bed operation approaches the theoretical limit of $28 \%$ as calculated by San Su et al. [7]. They optimized the yield to ethylene in the oxidative coupling reaction by setting optimal parameters for an elementary step surface mechanism combined with gas phase rate constants and thermodynamic property data compiled by Mims [28]. However, the maximum yield of $28 \%$ has already been exceeded in a membrane reactor by Akin et al. $[8,9]$. 
A temperature of about $800^{\circ} \mathrm{C}$ is needed to reach the best results for most of the catalysts. Generally diluting the reaction mixture with an inert gas $(\mathrm{He})$ leads to better results as homogeneous gas phase reactions are reduced.

\subsubsection{Process improvements in oxidative coupling}

The results mentioned in the last paragraph were obtained with single-pass flow reactors. Next to the development of various catalyst systems the following process modifications have been made in order to overcome the limitations of OCM.

\section{Distribution of $\mathrm{O}_{2}$ feed}

Per-pass methane conversion and C2 yield are limited because of the limit for the $\mathrm{O}_{2}$ concentration in the feed, due to explosion limits of $\mathrm{CH}_{4} / \mathrm{O}_{2}$ mixture. A second point is that in general high oxygen partial pressure promotes over-oxidation. With increasing $\mathrm{O}_{2}$ concentration methane conversion increases but the selectivity to $\mathrm{C} 2$ hydrocarbons decreases, making the process more exothermic and hence more hazardous. Using a membrane to distribute the oxygen feed could provide low oxygen concentration over the entire reactor length and limit combustion reactions, leading to lower exothermicity and higher C2-yield of the oxidative coupling process.

Akin et al. [8, 9] used a catalytically active fluorite structured $\mathrm{Bi}_{1.5} \mathrm{Y}_{0.3} \mathrm{Sm}_{0.2} \mathrm{O}_{3-\delta}$ (BYS) membrane tube. In their reactor the oxygen is fed on one side of the membrane and methane on the other. Only oxygen can permeate through the membrane via ionic conductivity and reaction thus takes place on the surface exposed to methane. The main advantage of this membrane reactor is avoiding direct contact between the reactants, leading to minimization of gas-phase complete oxidation reactions. Also with an ion conducting membrane the expensive generation of pure oxygen could be avoided: only oxygen can be transported through the membrane and air can be used as oxygen source. With this concept, up to $30 \%$ C2-yield was accomplished at $900^{\circ} \mathrm{C}$, more than ever reported in any other single pass reactor. The selectivity and methane conversion were $60 \%$ and $50 \%$, respectively. This was almost twice as high as obtained in co-feed experiments in the same reactor. High yields were found especially at low methane partial pressures. The system showed stable activity for 5 days at $900^{\circ} \mathrm{C}$. 
Kao et al. [16] used porous ceramic membranes (alumina or zirconia) in their reactor. In this case a separate catalyst is used for the OCM reaction and the membrane only acts as oxygen supply. Kao et al. chose the $\mathrm{Li} / \mathrm{MgO}$ system as OCM catalyst. At $750^{\circ} \mathrm{C}$ a maximum yield of $30 \%$ was reached at $53 \% \mathrm{C} 2$ selectivity, compared to $20.7 \%$ yield and $52.5 \%$ selectivity in a fixed bed reactor under the same conditions. Both, use of atmospheric air and lowering the membrane permeability improved the performance, showing that a lower oxygen flux leads to higher yield and selectivity. Haag et al. [29] used ionic oxygen conducting membranes, demonstrating that oxygen supply rates of the membrane and consumption in oxidative coupling have to be balanced. It was also stated that more active catalysts for oxidative coupling have to be developed to reach the optimal potential of the ionic conducting membrane reactor.

\section{Alternative reactor concepts}

Makri et al. [19] investigated the OCM process, using a gas recycle reactor with $\mathrm{Mn} / \mathrm{Na}_{2} \mathrm{WO}_{4} / \mathrm{SiO}_{2}$ as catalyst. To separate ethylene, Linde $5 \mathrm{~A}$ molecular sieve pellets were placed after the reactor. This material was found to be effective in trapping of ethylene and only partially trapped ethane. Methane and CO were not trapped at all. The combustion products $\mathrm{CO}_{2}$ and $\mathrm{H}_{2} \mathrm{O}$ were also stored in the trap. Trapping takes place at room temperature and reactions at $770^{\circ} \mathrm{C}-850^{\circ} \mathrm{C}$, requiring a lot of cooling and heating. The products can be collected from the trap by heating to $250^{\circ} \mathrm{C}$. Continuous operation is possible by switching between two parallel traps. C2 yield values up to $53 \%$ were reached. Tonkovich et al. [30, 31] used a separative chemical reactor that simulated a countercurrent moving bed. High C2 selectivity (80\%) and methane conversion (65\%) could be obtained with a $\mathrm{Sm}_{2} \mathrm{O}_{3}$ catalyst at $725^{\circ} \mathrm{C}$, leading to around $50 \% \mathrm{C} 2$ yield.

\section{Coupling of exothermic and endothermic reactions}

A promising coupling concept of exothermic and endothermic reactions was presented by Czechowicz et al. [10]. In a serial process, oxidative coupling was carried out in the first part of the reactor over a $\mathrm{Li} / \mathrm{MgO}$-catalyst. After the catalyst bed naphtha was introduced. In the second part of the reactor (containing no catalyst) the endothermic pyrolysis of naphtha took place. It was demonstrated that such a 
process could be realized, always giving an increase in the $\mathrm{C}_{2} \mathrm{H}_{4}$ yield as compared to both single processes.

\section{Direct conversion of ethylene into less volatile products}

Choudhary et al. [3] reported two possible processes to overcome separation problems with ethylene by converting it to value-added products. Both options show only a low methane conversion and still recycling of methane is required.

- Two step process for methane to gasoline conversion. In a first step the catalytic OCM is performed. The second step consists of conversion of ethylene into LPG (C3-C4 hydrocarbons) and gasoline (C5-C10 hydrocarbons) with the use of a bifunctional pentasil zeolite catalyst. Up to $90 \%$ ethylene conversion and $80 \%$ aromatic selectivity were obtained with the diluted ethylene stream. The mixture produced in oxidative coupling can directly be used in the second step, avoiding separation steps between the two processes $[3,32]$.

- Multi-step process for methane to ethylene oxide conversion. First methane coupling to ethylene is carried out. Afterwards selective oxidation of carbon monoxide to carbon dioxide and separation of the traces of $\mathrm{CO}$ from the resulting gas stream is performed. In the last step, vapor phase oxidation of the ethylene present in the product stream of step 2 is carried out, producing ethylene oxide over a supported silver catalyst. This process was found to be technically feasible.

\subsubsection{Conclusions oxidative coupling}

Efficient production of ethylene through oxidative coupling requires a selective catalyst and optimal process operation and conditions. It was found that the $\mathrm{Mn} / \mathrm{Na}_{2} \mathrm{WO}_{4} / \mathrm{SiO}_{2}$ catalyst gives the highest yield for the coupling process. Application of a ceramic membrane reactor in combination with this catalyst seems a promising option, but a thorough comparison between membrane and co-feed with the $\mathrm{Mn} / \mathrm{Na}_{2} \mathrm{WO}_{4} / \mathrm{SiO}_{2}$ catalyst is needed. Tymen Tiemersma, a second $\mathrm{PhD}$ student involved in the current project, will investigate the oxidative coupling reaction in both co-feed and membrane operation. His results are described in his $\mathrm{PhD}$ thesis (Tymen Tiemersma, Fundamentals of Chemical Reaction Engineering, University of Twente). The most important results about the oxidative coupling process were also used in this 
thesis and the most relevant findings are included in the conclusions of this thesis in chapter 7. 


\subsection{Steam and dry reforming of methane}

\subsubsection{Introduction}

As mentioned in the previous paragraph, OCM is always accompanied by highly exothermic side combustion reactions producing $\mathrm{CO}_{2}$ and $\mathrm{H}_{2} \mathrm{O}$. The thermal energy and side products can be used for the endothermic steam and dry reforming reactions of methane $[33,34]$ :

$$
\begin{array}{ll}
\mathrm{CH}_{4}+\mathrm{H}_{2} \mathrm{O} \rightarrow \mathrm{CO}+3 \mathrm{H}_{2} & \text { (7) } \Delta \mathrm{H}_{298}^{0}=+206 \mathrm{~kJ} \mathrm{~mol}^{-1} \\
\mathrm{CH}_{4}+\mathrm{CO}_{2} \rightarrow 2 \mathrm{CO}+2 \mathrm{H}_{2} & \text { (8) } \Delta \mathrm{H}_{298}^{0}=+247 \mathrm{~kJ} \mathrm{~mol}^{-1}
\end{array}
$$

The steam reforming reaction (7) creates synthesis gas with a $\mathrm{H}_{2}: \mathrm{CO}$ ratio of $3: 1$ and in the dry reforming reaction (8) a $\mathrm{H}_{2}: \mathrm{CO}$ ratio of 1 is produced. Both reactions take place simultaneously and thus a $\mathrm{H}_{2}: \mathrm{CO}$ ratio between 1 and 3 will be achieved. Applications of synthesis gas include Fischer Tropsch, $\mathrm{CH}_{3} \mathrm{OH}, \mathrm{CH}_{3} \mathrm{COOH}$ or $\mathrm{NH}_{3}$ synthesis or iron ore reduction. Both steam reforming reactions are highly endothermic and are carried out typically above $700^{\circ} \mathrm{C}$, where the products are thermodynamically favored. Under reforming conditions the water gas shift reaction also occurs.

$$
\mathrm{CO}_{2}+\mathrm{H}_{2} \rightarrow \mathrm{CO}+\mathrm{H}_{2} \mathrm{O} \quad \text { (9) } \Delta \mathrm{H}^{0}{ }_{298}=+41 \mathrm{~kJ} \mathrm{~mol}^{-1}
$$

The products of steam reforming are dictated by thermodynamics of reaction (7), (8) and (9) [35]. In presence of oxygen the catalytic partial oxidation of methane is also possible (10):

$$
\mathrm{CH}_{4}+0.5 \mathrm{O}_{2} \rightarrow \mathrm{CO}+2 \mathrm{H}_{2} \quad \text { (10) } \Delta \mathrm{H}^{0}{ }_{298}=-36 \mathrm{~kJ} \mathrm{~mol}^{-1}
$$

In the next paragraphs, the reaction mechanism of the methane reforming process and the activity of several catalysts on various supports will be discussed. Furthermore catalyst deactivation and reforming activity for higher alkanes will be discussed.

\subsubsection{Reaction mechanism}

Wei et al. [36] presented a comprehensive reaction scheme for the reforming process with both $\mathrm{CO}_{2}$ and $\mathrm{H}_{2} \mathrm{O}$, that also includes water gas shift reaction. The mechanism is shown in Figure 1.1. It was stated that this mechanism is applicable to all metal 
catalysts. As also reported by Dicks [37], it is stated that the rate limiting step in the process is the formation of radicals from methane. This means that $\mathrm{CH}_{4}$ decomposes to chemisorbed carbon $\left(\mathrm{C}^{*}\right)$ via sequential elementary $\mathrm{H}$-abstraction steps. As abstraction of the first hydrogen atom seems to have the highest activation energy, the surface will be mainly occupied by $\mathrm{C}^{*}$ and have low $\mathrm{CH}_{\mathrm{x}}$ coverages. The chemisorbed carbon is then removed by reactions with $\mathrm{CO}_{2}$ and $\mathrm{H}_{2} \mathrm{O}$.

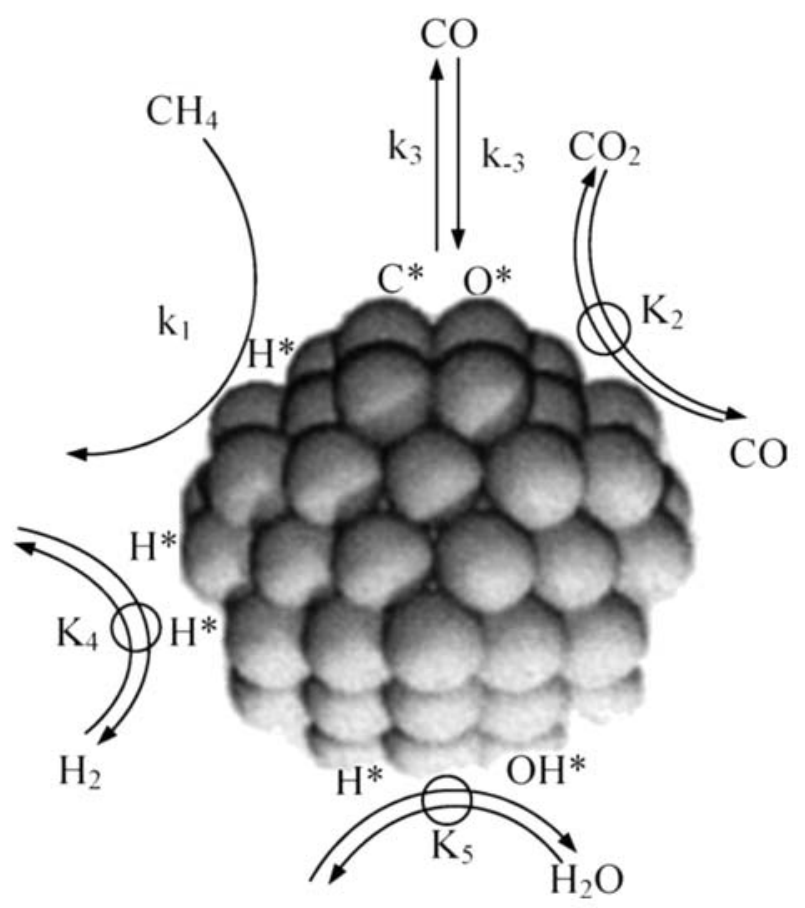

Figure 1.1: Reaction mechanism for Methane steam reforming, dry reforming and water gas shift reaction. Hydrogen, water and carbon dioxide steps are on equilibrium. Carbon monoxide dissociation is reversible and methane activation rate determining. [36]-Reproduced by permission of The Royal Society of Chemistry

In isotopic experiments with $\mathrm{D}_{2}$ instead of $\mathrm{H}_{2}$ and ${ }^{13} \mathrm{CH}_{4}$ instead of ${ }^{12} \mathrm{CH}_{4}$ it was shown that steps involving $\mathrm{H}_{2} \mathrm{O}$ and $\mathrm{CO}_{2}$ were much faster than kinetically relevant $\mathrm{C}-\mathrm{H}$ bond activation steps. For example dissociation of $\mathrm{CO}_{2}$ to $\mathrm{CO}$ and oxygen occurred in both directions many times during each $\mathrm{CH}_{4}$ chemical conversion turnover. The same was found for the $\mathrm{H}_{2} \mathrm{O}$ activation steps, meaning that the water gas shift reaction would always be equilibrated during reforming [35]. In the overall process reactions with water, carbon dioxide and hydrogen are at equilibrium. The 
dissociation of $\mathrm{CO}$ is determined by kinetics instead of thermodynamics and the hydrogen abstraction from methane determines the reaction progress.

\subsubsection{Catalysts used for reforming reactions}

Industrial practice in reforming reactions relies on $\mathrm{Ni}$-catalysts [38], because of cost and availability concerns about noble metals. Ni-catalysts however show a tendency to deactivate. Two potential causes of deactivation exist [39]: coke deposition and sintering of the metal particles.

The relative activities of different metals for steam and dry reforming have been compared by several authors [33, 40-43]. Hegarty et al. [33] compared 1wt\% of Co, $\mathrm{Cu}, \mathrm{Fe}, \mathrm{Ni}, \mathrm{Pd}$ and $\mathrm{Pt}$ supported on zirconia for steam reforming between $400^{\circ} \mathrm{C}$ and $800^{\circ} \mathrm{C}$. Ni showed much less activity compared to Pt or Pd. Low activity and significant deactivation due to carbon deposition was found on $\mathrm{Fe}, \mathrm{Cu}$ and $\mathrm{Co}$. $\mathrm{Pt} / \mathrm{ZrO}_{2}$ was not only the most active but also the most stable catalyst. Rostrup Nielsen [42] and Quin [40] found $\mathrm{Rh}$ and $\mathrm{Ru}$ as the most active metals in steam reforming. Some main group metals were also investigated as alternatives for $\mathrm{Ni}$ or noble metal catalysts [44-46], but all materials showed relatively low activity.

\subsubsection{Catalyst deactivation}

The most common deactivation of steam reforming catalysts occurs by carbon deposition. Coke originates mainly from two reactions: methane decomposition to $\mathrm{C}$ and $\mathrm{H}_{2}$ and carbon monoxide disproportionation via the Bouduard reaction (11). The former is endothermic and favored at high temperatures and low pressures, while the latter is exothermic and favored at low temperatures and high pressures. Noble metals however were found resistant to coking and appeared stable for long periods.

$$
2 \mathrm{CO} \rightarrow \mathrm{CO}_{2}+\mathrm{C}
$$

The role of the support was tested by Nagaoka et al. [39], O'Connor et al. [47] and Bitter et al. [48, 49]. Nagaoka compared $\mathrm{Pt}$ on $\mathrm{Al}_{2} \mathrm{O}_{3}$ and $\mathrm{Pt}$ on $\mathrm{ZrO}_{2}$ in methane dry reforming. $\mathrm{Pt} / \mathrm{ZrO}_{2}$ was found to be stable for more than 500 hours at $900 \mathrm{~K}$, while Pt on alumina deactivated rapidly under the same conditions. It was stated that the stability of Pt catalysts strongly depends on the nature of the support and its ability to form carbonates, leading to carbon deposition. The deactivation of Pt on alumina was 
mainly ascribed to coke formation. High temperature regeneration with $\mathrm{CO}_{2}$ was possible, ruling out sintering of $\mathrm{Pt}$ as the cause of deactivation. Coke can be removed by the reverse Bouduard reaction (11), as high temperature thermodynamically favors the CO-side.

It was stated that coke formation on Pt/alumina occurred on Pt and on Lewis acid sites of the support through decomposition of $\mathrm{CH}_{4}$, as also stated by Wei [36]. This coke can be removed with $\mathrm{CO}_{2}$ at high temperatures. Coke on Pt supported on $\mathrm{ZrO}_{2}$ was considered more reactive than on alumina. Additionally, $\mathrm{CH}_{4}$ decomposition during dry reforming was slower on the zirconia support than on alumina [39]. In case of zirconia, this leads to a balanced combination of carbon formation on $\mathrm{Pt}$ and its oxidation by activated $\mathrm{CO}_{2}$. Coke hardly accumulates on $\mathrm{Pt} / \mathrm{ZrO}_{2}$ and thus the material is a stable catalyst in $\mathrm{CO}_{2}$ reforming. O' Connor et al. [47] and Sauvet et al. [46] confirmed that noble metals deposited on $\mathrm{ZrO}_{2}$ had a much higher stability for both reforming reactions compared to silica or alumina supported noble metals.

In the combined process of OCM and steam and dry reforming, alkali poisoning might be relevant as OCM catalysts usually contain alkali components, for example $\mathrm{Na}$ in the $\mathrm{Mn} / \mathrm{Na}_{2} \mathrm{WO}_{4} / \mathrm{SiO}_{2}$-system. Often potassium is added as a promoter to steam reforming catalysts, which can also lead to poisoning effects in case of too high concentrations of potassium. Effects of potassium on Ni catalysts are well described, but the effects to noble metals, e.g. Pt, in steam reforming of methane and ethane have not been reported so far.

Two effects of alkali addition are described in literature. Addition of potassium and other alkali can limit carbon formation but can also reduce catalytic activity. It is claimed that $\mathrm{K}$ prevents carbon formation on Ni catalysts by blocking step sites which are believed to be the nucleation sites for graphite formation [50]. In addition, potassium on Ni catalysts enhances coke gasification [51]. It was reported by Dicks et al. [37] that small amounts of potassium reduce the risk of carbon deposition by decreasing the acidity of the catalyst support.

A decreasing activity of $\mathrm{Ni} / \mathrm{Al}_{2} \mathrm{O}_{3}$ [52] was reported in methane dry reforming with increasing potassium concentration in the catalyst. A reduction in catalytic activity by 
potassium was also confirmed by Trimm [53] and Rostrup-Nielsen [41]. The activity of $\mathrm{Ni} / \mathrm{MgO}-\mathrm{Al}_{2} \mathrm{O}_{3}$ for methane steam reforming was reported to decrease by $85 \%$ when $1.1 \mathrm{wt} \%$ of $\mathrm{K}$ was added [54]. Decreasing reforming activity by addition of potassium was also found on $\mathrm{Rh} / \mathrm{La}-\mathrm{Al}_{2} \mathrm{O}_{3}$ [55]. Alkali poisoning to reforming catalysts often occurs in molten carbonate fuel cells, as alkali may be transported to the reforming catalyst either by the vapor phase or by creep along the walls of the fuel cell. According to Rostrup-Nielsen [56] the poisoning effect of $\mathrm{K}_{2} \mathrm{CO}_{3}$ is much stronger than the effect of $\mathrm{Na}_{2} \mathrm{CO}_{3}$ and $\mathrm{Li}_{2} \mathrm{CO}_{3}$.

\subsubsection{Reforming of higher alkanes}

It is well known that higher hydrocarbons are also reactive in reforming. Trimm reports in a review that all kinds of hydrocarbons can be reformed, e.g. alkanes, olefins, aromatics and oxygenates [57]. Ethane and ethylene are produced in the OCM process and it is desired that these products are not converted to $\mathrm{CO}$ and $\mathrm{H}_{2}$. Only a few studies have compared reactivity of various hydrocarbnons.

Sutton et al. [58] investigated dry reforming of a gas stream containing mol percentages of $\mathrm{H}_{2}$ (42), $\mathrm{CO}$ (15.5), $\mathrm{CH}_{4}(5.1), \mathrm{CO}_{2}$ (19) and $\mathrm{C}_{3} \mathrm{H}_{8}$ (18.3) over $\mathrm{Ni} / \mathrm{Al}$ (co-precipitated), $\mathrm{Ru} / \mathrm{Al}_{2} \mathrm{O}_{3}$ and $\mathrm{Pt} / \mathrm{ZrO}_{2}$. A higher reactivity of propane was found compared to methane. Wang et al. [59] investigated steam reforming of methane, ethane, n-butane and some higher hydrocarbons on $\mathrm{Pd} /$ ceria for temperatures ranging from 620 to $770 \mathrm{~K}$. The production of $\mathrm{CO}_{\mathrm{x}}$ increased with carbon number, indicating higher reactivity for higher hydrocarbons.

Via thermochemical calculations, Sinev [35] determined that activation of light alkanes through formation of free radicals is energetically favored compared to other activation mechanisms like proton abstraction or molecular ionization. Among alkanes, methane had the highest activation energy, indicating lower reactivity compared to other alkanes.

\subsubsection{Conclusions reforming processes}

A few conclusions about the steam reforming reaction can be drawn, summarizing the data available in literature. $\mathrm{Ni}$ is often used but deactivation by carbon deposition is a problem. The deactivation through coke formation will be more pronounced when reforming of ethane and ethylene is included [53, 57]. Pt or Pd supported on zirconia 
are promising catalysts as they showed high activity and stability. In general, catalyst activity and stability are largely dependent on the support. In the combined process of methane coupling and reforming, alkali deactivation of the reforming catalyst, released from the oxidative coupling catalyst could be a problem. Alkali deactivation is not well investigated for Pt-systems and will be discussed in this thesis.

The major challenge in the steam reforming process is the reactivity of higher hydrocarbons; reforming of higher hydrocarbons produced in the oxidative coupling reaction should be avoided. At the same time high reactivity towards methane is desired in steam reforming. Higher alkanes were found to be more reactive than methane in reforming processes for the catalysts tested until now. A more detailed approach of comparing several catalysts in their reforming activity towards methane and C2-hydrocarbons will be part of this thesis. 


\subsection{Problem definition \& aspects of integration}

The main goal of the overall process of oxidative coupling and reforming of methane is to produce ethylene and synthesis gas $\left(\mathrm{CO}\right.$ and $\left.\mathrm{H}_{2}\right)$ in one multifunctional reactor. The possible reactions are shown in Scheme 1. Methane coupling takes place oxidatively, resulting in C2 hydrocarbons (ethane and ethylene) and water (1). The side combustion reactions of methane (2) and C2-hydrocarbons (3) produce water and $\mathrm{CO}_{2}$, which can react with the remaining methane through steam or dry reforming to $\mathrm{CO}$ and $\mathrm{H}_{2}$ (4). The main challenge in the reaction concept is to suppress steam/dry reforming of ethane and ethylene (5!) in order to avoid complete reaction to synthesis gas.

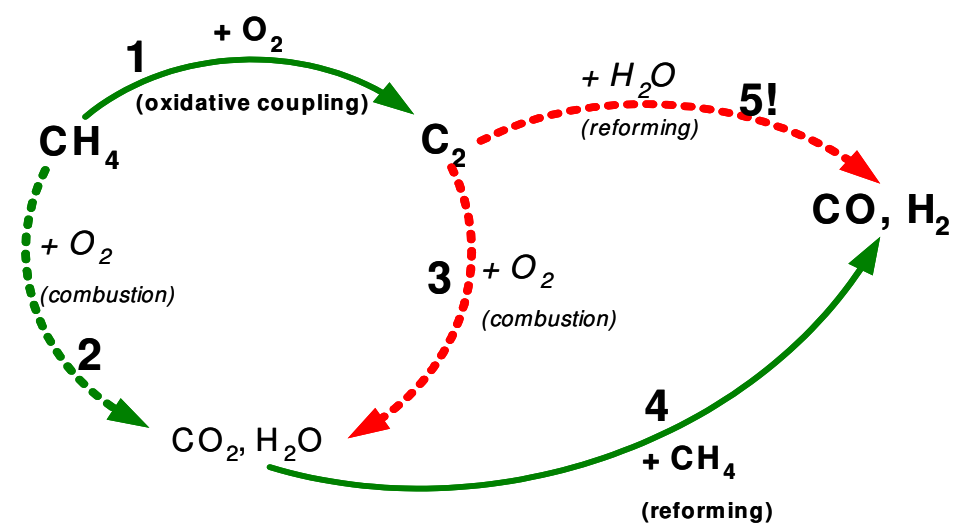

Scheme 1: Reactions occurring in combined process of methane coupling and steam reforming

The processes of oxidative coupling and reforming of methane can be integrated on several levels. Figure 1.2 shows several possibilities for the combination of both processes, ranging from integration on catalyst particle scale (Figure 1.2-I) to reactor scale (Figure 1.2-V). It should be noted that matching of reaction rates of oxidative coupling and reforming is required for autothermal operation. 
The type of concept that can be used strongly depends on the following issues.

1. Oxidation reactions of hydrocarbons on steam reforming catalyst should be prevented, e.g. by

- using a reforming catalyst that is not active in oxidation reactions

- preventing exposure of the reforming catalyst to oxygen

2. Reforming activity of ethane and ethylene can convert the complete mixture to synthesis gas and should be prevented as well, e.g. by

- limiting reforming activity of reforming catalyst towards ethane and ethylene

- avoiding contact of ethane and ethylene with the reforming catalyst

3. The overall process combines the highly exothermic coupling and combustion reactions with the endothermic reforming, requiring optimized heat transfer between both processes. This can be achieved by

- combining both processes in one catalyst particle or using one multifunctional catalyst and keep production and consumption of energy close to each other

- optimizing heat transfer in separate reaction zones or reactor compartments

4. High oxygen concentration leads to unselective oxidation reactions in the OCM section, producing $\mathrm{CO}_{2}$ and $\mathrm{H}_{2} \mathrm{O}$. To increase $\mathrm{C} 2$ yield and minimize combustion reactions a low oxygen partial pressure is needed in the OCM section. This can be achieved by distributed feeding of oxygen. 

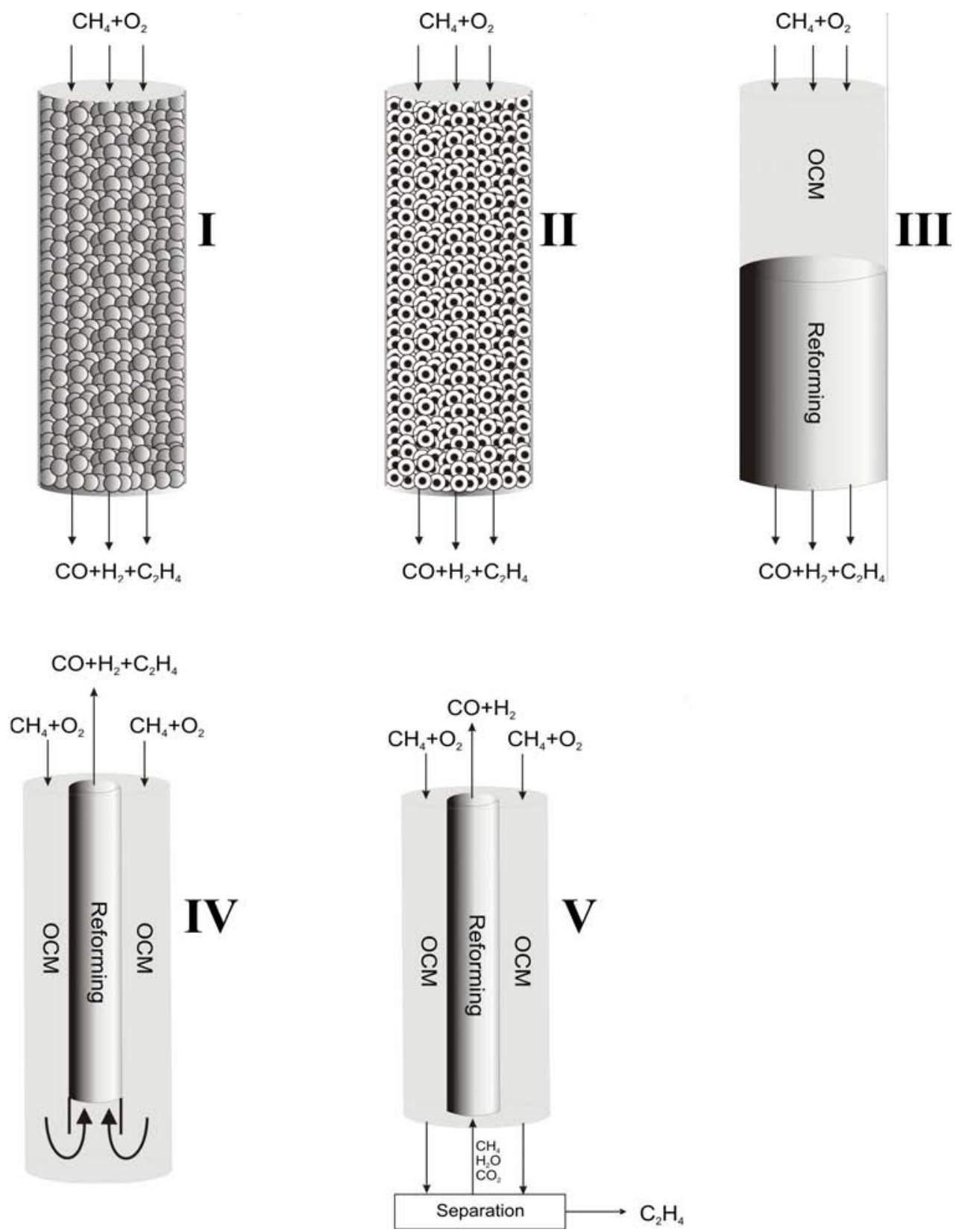

Figure 1.2: Different levels of integration of oxidative coupling and reforming of methane, ranging from particle scale (I) to reactor scale (V)

The reactor concepts shown in Figure 1.2 are shortly discussed below:

I. Combining the processes on particle scale, means in an ideal case combining both functions in one uniform multifunctional catalyst particle (Figure 1.2-I). In this concept, combustion activity for all hydrocarbons and reforming activity of the reforming catalyst towards ethane and ethylene need to be avoided. Heat exchange is very efficient in this concept. It should be noted that reducing the 
combustion activity of reforming catalysts is expected to be very difficult as reforming is performed on $\mathrm{Ni}$ or noble metal catalysts, that are very active in catalyzing combustion. Research in this thesis will not focus on this aspect. Therefore, reactor concepts that avoid contact between oxygen and the reforming catalyst are required.

II. An eggshell catalyst can be applied (Figure 1.2-II) to avoid contact between oxygen and the hydrocarbons on the reforming catalyst, eliminating combustions reactions on the reforming catalyst. The oxidative coupling catalyst is placed in the shell and the reforming function in the core of the catalyst. Oxygen present in the gas phase should be consumed in the outer layer of the particle to avoid diffusion to the core. In the core, a methane selective reforming catalyst is required to avoid reforming of ethane and ethylene. This shell and core system enable excellent heat exchange between the processes, requiring support materials with good conductivity.

III. Figure 1.2-III displays the combination of oxidative coupling and reforming in separate catalyst zones, within one reactor: a reforming zone in the center of the reactor can be combined with a catalyst zone for oxidative coupling on the outside of the reactor. Oxygen is consumed completely in the OCM section, avoiding combustion on the reforming catalyst. Reforming of ethane and ethylene still has to be avoided and efficient heat exchange between both processes is extremely difficult because of large exothermic and endothermic zones in the reactor, located far away from each other.

IV. Figure 1.2-IV also displays the combination of oxidative coupling and reforming placed in separate sections but now in a parallel configuration, improving heat transfer between the processes. Oxygen has to be exhausted after the OCM section, avoiding combustion on the reforming catalyst. A reforming catalyst that selectively reforms methane and does not convert ethane and ethylene is required for this concept. For efficient heat exchange between both processes it is important to limit the distance between exothermic and endothermic zones, e.g. using small reactor tubes or even micro reactor systems.

V. Figure $1.2-\mathrm{V}$ displays a concept of completely separate reactor compartments for oxidative coupling and reforming. In this case, reforming of ethane and 
ethylene and combustion of hydrocarbons on the reforming catalyst can be completely avoided by including separation steps between oxidative coupling and reforming. Efficient heat exchange between both processes can be achieved by limiting the distance between exothermic and endothermic zones, e.g. using small reactor tubes or micro reactor systems.

It should be noted that distributed feeding of oxygen (4) can be integrated in all presented concepts, to optimize operation of OCM reaction, increasing $\mathrm{C} 2$ yield by applying low oxygen concentration over the entire reactor length. As an example, concept 1-2-V is shown with distributed oxygen feeding in Figure 1.3.

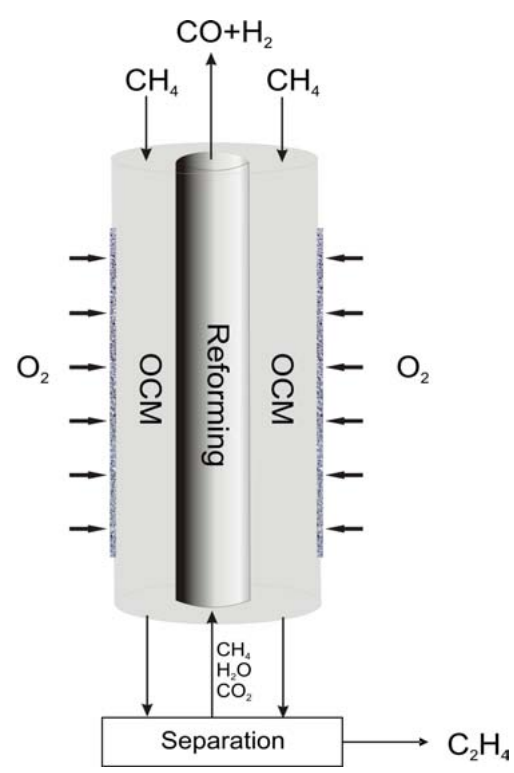

Figure 1.3: Reactor concept for combining oxidative coupling with distributed oxygen feeding with reforming; including separation of ethylene.

Research in this thesis and the parallel work by Tymen Tiemersma will focus on selection of a suitable reactor concept and catalysts for a combined process of oxidative coupling and reforming. This thesis will consist of a total of seven chapters, covering the following topics:

- Reforming competition between methane, ethane and ethylene will be the central topic of chapters 2, 3 and 4 of this thesis. The reforming of methane, ethane and ethylene on $\mathrm{Rh}, \mathrm{Pt}$ and $\mathrm{Pd}$ will be discussed in chapter 2. The influence of potassium modification of $\mathrm{Pt}$ supported on yttrium-stabilized 
zirconia (PtYSZ) on the steam reforming competition of methane and ethane will be described in chapter 3. The underlying mechanism of the effect of potassium to PtYSZ will be described in chapter 4 on the basis of XRD, FTIR CO spectroscopy and including CO TPD measurements.

- Chapter 5 discusses a reactive separation of ethylene to ethylbenzene in the mixture obtained in oxidative coupling.

- The activation of water on oxidic supports is a highly relevant process in steam reforming reactions and not well understood until now. In chapter 6 the activation of water on $\mathrm{ZrO}_{2}$ will be investigated, using water gas shift as a model reaction, With FT-IR characterization of hydroxyl groups, the activation of water and the role of these hydroxyl groups in water gas shift reaction on $\mathrm{Pt} / \mathrm{ZrO}_{2}$ will be investigated.

- Finally, chapter 7 will discuss and combine results of the earlier chapters, leading to possible reactor concepts and future possibilities for the combined process of oxidative coupling and reforming of methane. 


\subsection{References}

[1] J.H. Lunsford, Catalysis Today 63 (2000) 165.

[2] R. Spinicci, P. Marini, S. De Rossi, M. Faticanti, P. Porta, Journal of Molecular Catalysis A-Chemical 176 (2001) 253.

[3] T.V. Choudhary, D.W. Goodman, Catalysis Today 77 (2002) 65-78.

[4] L. Mleczko, M. Baerns, Fuel Processing Technology 42 (1995) 217-248.

[5] S.N. Vereshchagin, V.K. Gupalov, L.N. Ansimov, N.A. Terekhin, L.A. Kovrigin, N.P. Kirik, E.V. Kondratenko, A.G. Anshits, Catalysis Today 42 (1998) 361-365.

[6] S. Pak, P. Qiu, J.H. Lunsford, Journal of Catalysis 179 (1998) 222.

[7] Z.-Y. Ma, C. Yang, W. Wei, W.-H. Li, Y.-H. Sun, Journal of Molecular Catalysis A: Chemical 231 (2005) 75-81.

[8] F.T. Akin, Y.S. Lin, Catalysis Letters 78 (2002) 239.

[9] F.T. Akin, Y.S. Lin, Aiche Journal 48 (2002) 2298.

[10] D. Czechowicz, K. Skutil, A. Torz, M. Taniewski, Journal of Chemical Technology and Biotechnology 79 (2004) 182.

[11] A.G. Dedov, A.S. Loktev, I.I. Moiseev, A. Aboukais, J.F. Lamonier, I.N. Filimonov, Applied Catalysis A-General 245 (2003) 209.

[12] C. Hoogendam, 1996.

[13] K. Huang, F.Q. Chen, D.W. Lu, Applied Catalysis A-General 219 (2001) 61.

[14] K. Huang, X.L. Zhan, F.Q. Chen, D.W. Lu, Chemical Engineering Science 58 (2003) 81.

[15] S.F. Ji, T.C. Xiao, S.B. Li, L.J. Chou, B. Zhang, C.Z. Xu, R.L. Hou, A.P.E. York, M.L.H. Green, Journal of Catalysis 220 (2003) 47.

[16] Y.K. Kao, L. Lei, Y.S. Lin, Catalysis Today 82 (2003) 255.

[17] S. Kus, M. Otremba, M. Taniewski, Fuel 82 (2003) 1331.

[18] S. Kus, M. Otremba, A. Torz, M. Taniewski, Applied Catalysis A: General 230 (2002) 263.

[19] M. Makri, C.G. Vayenas, Applied Catalysis A-General 244 (2003) 301.

[20] A. Malekzadeh, M. Abedini, A.A. Khodadadi, M. Amini, H.K. Mishra, A.K. Dalai, Catalysis Letters 84 (2002) 45.

[21] S. Pak, J.H. Lunsford, Applied Catalysis A: General 168 (1998) 131.

[22] A. Palermo, J.P.H. Vazquez, A.F. Lee, M.S. Tikhov, R.M. Lambert, Journal of Catalysis 177 (1998) 259.

[23] S. Ramasamy, A.R. Mohamed, S. Bhatia, Reaction Kinetics and Catalysis Letters 75 (2002) 353.

[24] S. Takenaka, T. Kaburagi, I. Yamanaka, K. Otsuka, Catalysis Today 71 (2001) 31.

[25] J.E. Tenelshof, H.J.M. Bouwmeester, H. Verweij, Applied Catalysis A-General 130 (1995) 195.

[26] V.R. Choudhary, S.A.R. Mulla, B.S. Uphade, Fuel 78 (1999) 427.

[27] J.H. Lunsford, F.J.J.G. Janssen, R.A. Van Santen, in: G.J. Hutchings (Ed.), Environmental Catalysis, 2000, p. 87. 
[28] C.A. Mims, R. Mauti, A.M. Dean, K.D. Rose, J. Phys. Chem. 98 (1994) 1335713372.

[29] S. Haag, A.C. van Veen, C. Mirodatos, Catalysis Today 127 (2007) 157-164.

[30] A. Ray, A.L. Tonkovich, R. Aris, R.W. Carr, Chemical Engineering Science 45 (1990) 2431-2437.

[31] A.L. Tonkovich, R.W. Carr, R. Aris, Science 262 (1993) 221-223.

[32] V.R. Choudhary, S.A.R. Mulla, Industrial \& Engineering Chemistry Research 36 (1997) 3520-3527.

[33] M.E.S. Hegarty, A.M. O'Connor, J.R.H. Ross, Catalysis Today 42 (1998) 225.

[34] J.R.H. Ross, A.N.J. van Keulen, M.E.S. Hegarty, K. Seshan, Catalysis Today 30 (1996) 193.

[35] M.Y. Sinev, Journal of Catalysis 216 (2003) 468.

[36] J.M. Wei, E. Iglesia, Physical Chemistry Chemical Physics 6 (2004) 3754.

[37] A.L. Dicks, Journal of Power Sources 71 (1998) 111.

[38] K.H. Hou, R. Hughes, Chemical Engineering Journal 82 (2001) 311.

[39] K. Nagaoka, K. Seshan, K. Aika, J.A. Lercher, Journal of Catalysis 197 (2001) 34.

[40] D. Qin, J. Lapszewicz, Catalysis Today 21 (1994) 551-560.

[41] J.R. Rostrup-Nielsen, Journal of Catalysis 31 (1973) 173.

[42] J.R. Rostrup-Nielsen, J.H.B. Hansen, Journal of Catalysis 144 (1993) 38-49.

[43] K. Tomishige, M. Nurunnabi, K. Maruyama, K. Kunimori, Fuel Processing Technology 85 (2004) 1103.

[44] A.J. Brungs, A.P.E. York, J.B. Claridge, C. Marquez-Alvarez, M.L.H. Green, Catalysis Letters 70 (2000) 117.

[45] E. Ramirez-Cabrera, A. Atkinson, D. Chadwick, Applied Catalysis BEnvironmental 47 (2004) 127.

[46] A.L. Sauvet, J.T.S. Irvine, Solid State Ionics 167 (2004) 1.

[47] A.M. O'Connor, J.R.H. Ross, Catalysis Today 46 (1998) 203.

[48] J.H. Bitter, W. Hally, K. Seshan, J.G. van Ommen, J.A. Lercher, Catalysis Today 29 (1996) 349-353.

[49] J.H. Bitter, K. Seshan, J.A. Lercher, Journal of Catalysis 171 (1997) 279.

[50] J. Sehested, Catalysis Today 111 (2006) 103-110.

[51] J.W. Snoeck, G.F. Froment, M. Fowles, Industrial and Engineering Chemistry Research 41 (2002) 3548-3556.

[52] J. Juan-Juan, M.C. Roman-Martinez, M.J. Illan-Gomez, Applied Catalysis A: General 301 (2006) 9-15.

[53] D.L. Trimm, Catalysis Today 49 (1999) 3.

[54] M. Matsumura, C. Hirai, Journal of Chemical Engineering of Japan 31 (1998) 734.

[55] S.Y. Choung, M. Ferrandon, T. Krause, Catalysis Today 99 (2005) 257-262.

[56] J.R. Rostrup-Nielsen, L.J. Christiansen, Applied Catalysis A-General 126 (1995) 381.

[57] D.L. Trimm, Catalysis Today 37 (1997) 233.

[58] D. Sutton, S.M. Parle, J.R.H. Ross, Fuel Processing Technology 75 (2002) 45. 
[59] X. Wang, R.J. Gorte, Applied Catalysis A: General 247 (2003) 157-162. 


\title{
Chapter
}

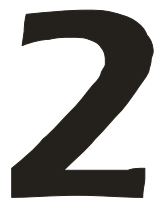

Comparative study of steam reforming of methane, ethane and ethylene on Pt, Rh and Pd supported on yttrium-stabilized zirconia

\begin{abstract}
Steam reforming of methane, ethane and ethylene was compared on $\mathrm{Pt}, \mathrm{Rh}$ and $\mathrm{Pd}$ supported on Yttrium stabilized zirconia (YSZ). Both, reactivity and product distribution changed with the use of different catalysts. The order of activity for the hydrocarbons on $\mathrm{Rh}$ was $\mathrm{C}_{2} \mathrm{H}_{6}>\mathrm{C}_{2} \mathrm{H}_{4}>\mathrm{CH}_{4}$. On Pt, methane reacted faster than the C2 hydrocarbons: $\mathrm{CH}_{4}>\mathrm{C}_{2} \mathrm{H}_{6}, \mathrm{C}_{2} \mathrm{H}_{4}$. The lowest coking tendency was observed on $\mathrm{Pt} / \mathrm{YSZ}$. Pd/YSZ showed a high tendency to coke formation and blocked the reactor. $\mathrm{Pt} / \mathrm{YSZ}$ produced synthesis gas $\left(\mathrm{CO}\right.$ and $\left.\mathrm{H}_{2}\right)$ only, for all hydrocarbons. However, more importantly, in this study all significant reactions during ethane steam reforming on $\mathrm{Rh} / \mathrm{YSZ}$ have been clarified. Methane formation additionally to synthesis gas production on this catalyst was assigned to hydrogenolysis of ethane by consecutive conversion of hydrogen produced in ethane steam reforming.
\end{abstract}




\subsection{Introduction}

With the depletion of mineral oil and simultaneous increase in known natural gas reserves, it is expected that methane will eventually become a major resource for chemicals and liquid fuels. Much of the methane is found in regions that are far removed from industrial complexes and often offshore, implying that transport is uneconomical or even impossible. This has led to worldwide efforts for directly converting methane into easy transportable value-added products.

Direct and indirect methods are known for methane valorisation. The indirect routes are mainly based on the steam reforming to produce synthesis gas $\left(\mathrm{CO}\right.$ and $\left.\mathrm{H}_{2}\right)$, which can then be converted to the desired liquid fuels. Since reforming is a highly energy consuming process, considerable efforts have been made for many years to develop direct conversion routes. One of the possibilities in this respect is the slightly exothermic oxidative coupling of methane that leads to ethylene (1).

$$
\mathrm{CH}_{4}+1 / 2 \mathrm{O}_{2} \rightarrow 1 / 2 \mathrm{C}_{2} \mathrm{H}_{4}+\mathrm{H}_{2} \mathrm{O} \quad \Delta \mathrm{H}^{\circ}{ }_{298} \quad=-140 \mathrm{~kJ} / \mathrm{mol}
$$

In the coupling process also ethane is formed. Next to reaction (1) the highly exothermic complete oxidation of methane is unavoidable (2).

$\mathrm{CH}_{4}+2 \mathrm{O}_{2} \rightarrow \mathrm{CO}_{2}+2 \mathrm{H}_{2} \mathrm{O} \quad \Delta \mathrm{H}^{\circ}{ }_{298} \quad=-801 \mathrm{~kJ} / \mathrm{mol}$

As a high selectivity to reaction (1) is always compromised with a low conversion, methane conversion will never be complete. Limitations of the reaction in a co-feed reactor of methane and oxygen have led to recent development of several alternatives. Makri et al used a gas recycle reactor [1], Choudhary proposed the use of a countercurrent moving bed [2]. Also research on plasma [3] and solid-state electrolyte reactors [4] has been carried out. Additionally combinations with other reactions have been proposed: catalytic oxidative coupling and gas phase partial oxidation [5], cogeneration of ethylene and electricity through oxidative coupling [6], oxidative coupling of methane and oxidative dehydrogenation [7] and oxidative coupling of methane and pyrolysis of naphtha [8]. All of the processes face difficulties with economic and/or technical feasibility. 
A closer look at equations 1 and 2 shows that the side products of the coupling process can also react with methane through the endothermic steam and dry reforming reactions (3) \& (4).

$$
\begin{array}{lll}
\mathrm{CH}_{4}+\mathrm{H}_{2} \mathrm{O} \rightarrow 3 \mathrm{H}_{2}+\mathrm{CO} & \Delta \mathrm{H}^{\circ}{ }_{298} & =206 \mathrm{~kJ} / \mathrm{mol} \\
\mathrm{CH}_{4}+\mathrm{CO}_{2} \rightarrow 2 \mathrm{H}_{2}+2 \mathrm{CO} & \Delta{\mathrm{H}^{\circ}}_{298} & =247 \mathrm{~kJ} / \mathrm{mol}
\end{array}
$$

The idea of the current research is creating an auto thermal process, combining the exothermic oxidative coupling of methane and highly exothermic combustion (side) reactions with the endothermic reactions of methane steam and dry reforming. The intention is to convert methane to ethylene and synthesis gas $\left(\mathrm{CO}\right.$ and $\left.\mathrm{H}_{2}\right)$ in one multifunctional reactor. Allowing the side combustion reactions next to oxidative coupling to increase the methane conversion, and auto thermal operation including energy consumption via steam and dry reforming of remaining methane are important issues in this concept.

Two side reactions are involved that can disturb the process. In the oxidative coupling reaction combustion of C2-hydrocarbons can also occur. This, however, can be minimized by avoiding the contact of oxygen and the coupling products.

The second challenge is the activity of ethane and ethylene in the reforming reactions [9]. As a result of the methane coupling reaction, a mixture of methane, ethane and ethylene is present (next to $\mathrm{CO}_{2}, \mathrm{H}_{2} \mathrm{O}$ and $\mathrm{CO}$ ). To avoid complete reaction to synthesis gas, steam/dry reforming of ethane and ethylene has to be limited. High temperature is required in the overall process. Under these conditions water gas shift reaction will convert most of the $\mathrm{CO}_{2}$ to $\mathrm{H}_{2} \mathrm{O}$ (5). Therefore main focus in this study is on steam reforming.

$\mathrm{CO}_{2}+\mathrm{H}_{2} \rightarrow \mathrm{H}_{2} \mathrm{O}+\mathrm{CO} \quad \Delta \mathrm{H}^{\circ}{ }_{298}=41 \mathrm{~kJ} / \mathrm{mol}$

Only few publications are available in the field of steam reforming of higher hydrocarbons than methane. Wang et al [10] measured steam reforming rates for methane, ethane, n-butane and some higher hydrocarbons on $\mathrm{Pd} /$ ceria for temperatures ranging from 620 to $770 \mathrm{~K}$. The production of $\mathrm{CO}_{\mathrm{x}}$ increased with carbon number, pointing out higher reactivity for higher hydrocarbons. The same tests 
were also carried out on $\mathrm{Pt} /$ ceria which had similar catalytic properties, leading to identical rates and selectivity for both catalysts.

Takeguchi et al [11] compared steam reforming of methane, ethane and ethylene on $\mathrm{Ni}$-YSZ cermets. C2-hydrocarbons were completely converted to $\mathrm{CO} / \mathrm{CO}_{2}$ at $800^{\circ} \mathrm{C}$ while methane conversion was about $85 \%$ under these conditions. Complete conversion of methane was found at temperatures higher than $850^{\circ} \mathrm{C}$.

While most researchers focused on separate reforming of hydrocarbons, Sutton et al [12] studied dry reforming of a gas mixture containing both $\mathrm{CH}_{4}$ and $\mathrm{C}_{3} \mathrm{H}_{8}$ over Ni/Al (co-precipitated), $\mathrm{Ru} / \mathrm{Al}_{2} \mathrm{O}_{3}$ and $\mathrm{Pt} / \mathrm{ZrO}_{2}$. At $800^{\circ} \mathrm{C}$ propane was completely consumed and $\mathrm{CH}_{4}$ partially remained unconverted, showing higher reactivity of the larger hydrocarbon.

Sperle et al [13] determined the coking tendency for steam reforming of methane in presence of minor amounts of $\mathrm{C} 2$ and $\mathrm{C} 3$ hydrocarbons. $\mathrm{A} \mathrm{Ni} / \mathrm{MgAl}_{2} \mathrm{O}_{4}$ catalyst was used between 480 and $550^{\circ} \mathrm{C}$. It was found that coking increased with carbon number and a dramatic increase was noted for olefins. Sidjabat and Trimm [14] also found higher deactivation rates for ethane and propane compared to methane in steam reforming on $\mathrm{Ni} / \mathrm{MgO}$ at $500^{\circ} \mathrm{C}$.

An ideal reforming catalyst in the combined process of oxidative coupling and reforming of methane would selectively react with methane in presence of ethane/ethylene at temperatures comparable to oxidative coupling conditions. Comparative studies between different metal catalysts have been limited to methane until now $[15,16]$. Attention is focused on low temperature measurements and highly dispersed catalysts. So far the relative reactivity in mixtures of methane, ethane and ethylene has not been published. Also a comparison of methane, ethane and ethylene separately on different metal catalysts is not available. The latter issue will be studied first, while behaviour in mixtures will be studied in future work.

Usually Ni or noble metals like $\mathrm{Ru}, \mathrm{Rh}, \mathrm{Pd}$, Ir and Pt are used as active metal in steam reforming catalysts. Compared to $\mathrm{Rh}$ and $\mathrm{Ir}$, Pt and Pd are well known for low reactivity in splitting the $\mathrm{C}-\mathrm{C}$ bond $[17,18]$ and were therefore considered promising in this study. Metals with even lower reactivity towards $\mathrm{C}-\mathrm{C}$ bonds, for example $\mathrm{Cu}$ 
and $\mathrm{Au}$, show hardly any activity in C-H splitting [19], which would be necessary to activate any alkane. Rh was also included in this study as it shows high steam reforming activity. In case of $\mathrm{C} 2$ reforming and especially ethylene, coking is an issue. This eliminated the use of Ni. In this study Yttrium stabilized zirconia (YSZ) was selected as catalyst support, as zirconia supported catalysts are well-known for high resistance to coking [20]. In this publication, results of a comparative study of steam reforming of methane, ethane and ethylene on $\mathrm{Rh}, \mathrm{Pd}$ and $\mathrm{Pt}$ supported on YSZ are discussed. 


\subsection{Experimental}

Catalysts were prepared by wet impregnation of Yttrium stabilized zirconia (YSZ) obtained from TOSOH (TZ-8Y). The precursors were $\mathrm{RhCl}_{3}, \mathrm{PdCl}_{2}$ and $\mathrm{H}_{2} \mathrm{PtCl}_{6}$ obtained from Alfa Aesar. Around $10 \mathrm{~g}$ of support was impregnated with a solution containing $0.01 \mathrm{~g} \mathrm{Rh}, \mathrm{Pt}$ or Pd per $\mathrm{ml}$ aqueous solution. Catalysts were calcined at $900^{\circ} \mathrm{C}$ in case of $\mathrm{Rh}$ and at $750^{\circ} \mathrm{C}$ for $\mathrm{Pt}$ and $\mathrm{Pd}$. Synthetic air (ml/min) was used during the $15 \mathrm{~h}$ calcination period $\left(\operatorname{ramp~} 5^{\circ} \mathrm{C} \min ^{-1}\right)$.

Activity tests were carried out in a micro reactor flow setup. The reactor consisted of a quartz tube with inner and outer diameter of respectively 4 and $6 \mathrm{~mm}$. 200mg of catalyst was loaded between quartz wool. Catalyst particles with a diameter between 0.3 and $0.6 \mathrm{~mm}$ were loaded in the reactor, resulting in a pressure drop around $0.1 \mathrm{bar}$.

Methane (Hoekloos 4.5), ethane (Indugas 4.0) and ethylene (Indugas 3.5) were fed separately on all three catalysts. To ensure constant water/carbon ratio, methane concentration was chosen twice as high as ethane and ethylene. The reaction mixtures had the following composition: 10vol.\% of methane or $5 \mathrm{vol} . \%$ of ethane or ethylene in $\mathrm{Ar}$ (Hoekloos 5.0). A total flow rate of $200 \mathrm{ml}^{\mathrm{min}} \mathrm{m}^{-1}$ was applied. Water was added through a double saturation step of the gas mixture. In a first saturator the gas stream was contacted with water at $65^{\circ} \mathrm{C}$, followed by condensation at $55^{\circ} \mathrm{C}$ in a second saturator. This led to a stable water concentration of $12 \mathrm{vol} \%$, resulting in a constant water/carbon ratio of 1.2 for all experiments. Before activity test the samples were heated to $500^{\circ} \mathrm{C}$ in argon and reduced in $2.5 \mathrm{vol} . \% \mathrm{H}_{2}$ (Indugas 5.0) / Ar for $1 \mathrm{~h}$ (flow rate: $200 \mathrm{ml} / \mathrm{min}$ ).

Conversion of hydrocarbons was measured between 500 and $800^{\circ} \mathrm{C}$ for $\mathrm{Rh} / \mathrm{YSZ}$ with intervals of $50^{\circ} \mathrm{C}$. To avoid extensive sintering of the $\mathrm{Pt}$ and $\mathrm{Pd}$ samples, the maximum temperature applied was $700^{\circ} \mathrm{C}$. The product and reactant gas composition was analysed by a Varian 3800 Gas Chromatograph equipped with two columns (Molsieve 5A and PoraPlotQ) and two TCD detectors. For all experiments the water gas shift constant was calculated by equation $5 \mathrm{a}$ :

$$
K=\frac{\left[\mathrm{H}_{2}\right]\left[\mathrm{CO}_{2}\right]}{\left[\mathrm{H}_{2} \mathrm{O}\right][\mathrm{CO}]}
$$


Values calculated based on the observations are compared to theoretical equilibrium values calculated using HSC chemistry 4.0 software. HSC Chemistry was also used to calculate equilibrium compositions of the reaction mixtures.

For all experiments $200 \mathrm{mg}$ of catalyst was used and total flow rate was $200 \mathrm{ml} / \mathrm{min}$. During water gas water gas shift measurements, 1vol.\% of CO in Argon with 12vol.\% of water was fed. A mixture of $\mathrm{CO}_{2}$ (10vol.\%), $\mathrm{H}_{2} \mathrm{O}(12 \mathrm{vol} . \%)$ and $\mathrm{H}_{2}(20 \mathrm{vol} . \%)$ in $\mathrm{Ar}$ was used for methanation on Rh/YSZ; hydrogenolysis was studied using a $\mathrm{H}_{2}$ (20vol.\%) / ethane (5vol.\%) mixture in Ar.

Metal dispersion was determined with $\mathrm{H}_{2}$-chemisorption on a Micromeritics ChemiSorb 2750 pulse chemisorption apparatus. Elemental composition of the samples was determined with XRF on a Philips PW 1480 x-ray spectrometer. A H/Me ratio of 1 was assumed. 


\subsection{Results}

\subsubsection{Catalyst characterization}

Table 2.1 displays the elemental analysis and results of the dispersion measurements for Pt/YSZ, Rh/YSZ and Pd/YSZ. The XRF results show that around $1 \mathrm{wt} \%$ of metal is present in all catalysts. As expected, metal dispersion values (Table 2.1) of Pt/YSZ and $\mathrm{Rh} / \mathrm{YSZ}$ were low because of high calcination temperatures and low surface area of the support material $\left(16 \mathrm{~m}^{2} / \mathrm{g}\right)$.

Table 2.1: Metal dispersion and elemental composition for Pt/YSZ, Rh/YSZ and Pd/YSZ

\begin{tabular}{|l|c|c|}
\hline Catalyst & Metal dispersion $^{1}$ & Metal content $^{2}$ \\
\hline $1 \mathrm{wt} \% \mathrm{Pt} / \mathrm{YSZ}$ & $1.5 \%$ & $1.04 \mathrm{wt} \% \mathrm{Pt}$ \\
\hline $1 \mathrm{wt} \% \mathrm{Rh} / \mathrm{YSZ}$ & $6.3 \%$ & $0.99 \mathrm{wt} \% \mathrm{Rh}$ \\
\hline $1 \mathrm{wt} \% \mathrm{Pd} / \mathrm{YSZ}$ & n.d. & $0.99 \mathrm{wt} \% \mathrm{Pd}$ \\
\hline
\end{tabular}

${ }^{1}$ Determined by $\mathrm{H}_{2}$ chemisorption, $\mathrm{H} / \mathrm{Me}$ ratio of 1

${ }^{2}$ Determined by XRF

\subsubsection{Rh/YSZ}

Steam reforming of methane, ethane and ethylene was tested on Rh/YSZ in separate experiments. The initial conversions of methane, ethane and ethylene as a function of temperature are shown in Figure 2.1. It can be seen that the reactivity of ethylene and ethane is much higher than of methane, complete conversion of C2-hydrocarbons already occurs at temperatures around $600^{\circ} \mathrm{C}$. In case of ethylene reforming, $\mathrm{Rh} / \mathrm{YSZ}$ deactivated at $500^{\circ} \mathrm{C}$ and $550^{\circ} \mathrm{C}$ (not shown). The conversion of ethylene decreased by $10 \%$ within the first hour of reaction at $500^{\circ} \mathrm{C}$, whereas the decrease was limited to $2 \%$ in the first hour at $550^{\circ} \mathrm{C}$. Thermodynamic calculations confirmed that carbon formation can be a factor under these conditions, as the equilibrium leads to carbon next to synthesis gas. Oxidation at $850^{\circ} \mathrm{C}$ reactivated the catalyst. Experiments at temperatures above $600^{\circ} \mathrm{C}$ with ethylene as well as all experiments with ethane and methane showed stable conversion with time on-stream. The carbon mass balances was closed within $5 \%$ for all experiments. 


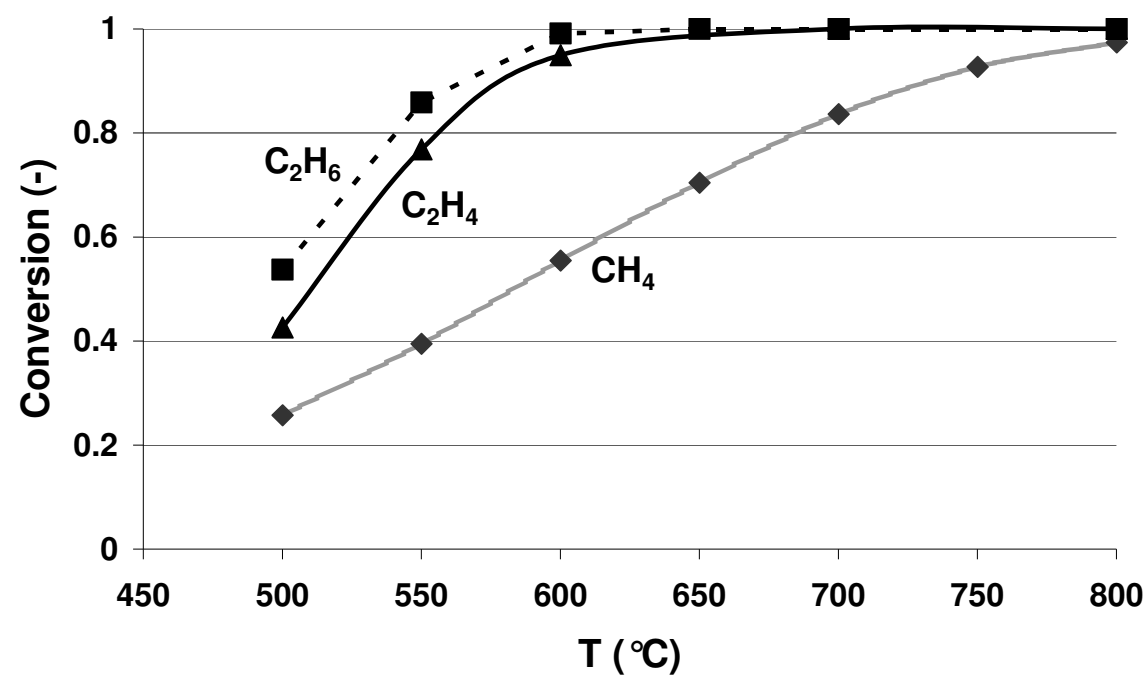

Figure 2.1: Conversion of methane (10vol.\%), ethane (5vol.\%) and ethylene (5vol.\%) when fed separately in steam reforming on $\mathrm{Rh} / \mathrm{YSZ}$ between $500^{\circ} \mathrm{C}$ and $800^{\circ} \mathrm{C}$

Methane reforming produces mainly $\mathrm{H}_{2}$ and $\mathrm{CO}_{2}$ at temperatures up to $500^{\circ} \mathrm{C}$. $\mathrm{CO}$ formation becomes notable at $550^{\circ} \mathrm{C}$. Relatively more $\mathrm{CO}$ is formed at higher temperatures. In Figure 2.2 the WGS constant, calculated from the experimental product concentrations, is compared to the theoretical equilibrium value as a function of temperature for all three experiments. For methane, equilibrium is achieved during

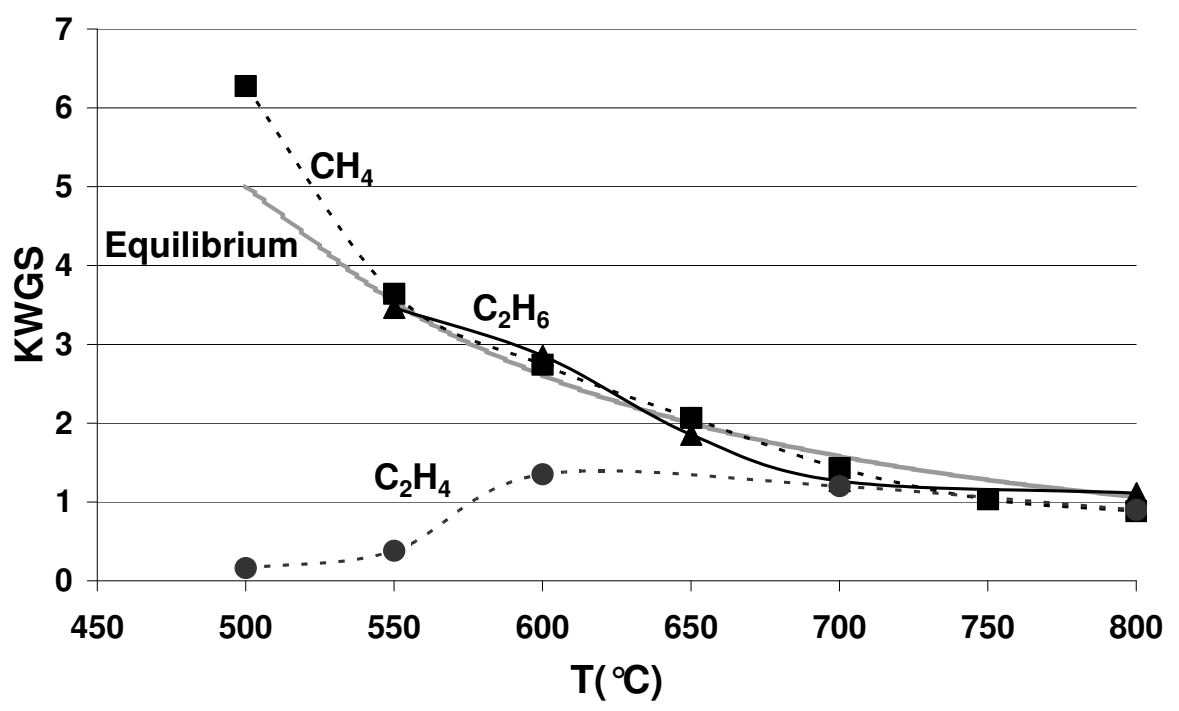

Figure 2.2: WGS equilibrium values between $500^{\circ} \mathrm{C}$ and $800^{\circ} \mathrm{C}$ compared to calculated WGS constants for steam reforming of methane, ethane and ethylene on Rh/YSZ 
steam reforming at all temperatures (Figure 2.2). For reforming of ethane, the water gas shift reaction is also equilibrated. Clearly, WGS equilibrium is not reached in ethylene reforming. $\mathrm{CO}$ was the main product besides hydrogen under all conditions, while only minor amounts of $\mathrm{CO}_{2}$ were formed.

The conversion of ethane is slightly higher than that of ethylene (Figure 2.1), while ethylene is generally considered more reactive. Therefore, a closer look is taken at the difference in product composition in both experiments. In case of ethane reforming (Figure 2.3a), interestingly, methane is one of the products next to the expected CO, $\mathrm{CO}_{2}$ and $\mathrm{H}_{2}$ mixture. The highest methane yield, almost $30 \%$, is observed at $600^{\circ} \mathrm{C}$. Higher temperatures increase selectivity to synthesis gas. The product composition in case of ethylene reforming is shown in Figure 2.3b. Under all conditions measured, the main product is a mixture of $\mathrm{CO}, \mathrm{CO}_{2}$ and $\mathrm{H}_{2}$. Only minor amounts of methane and ethane were formed
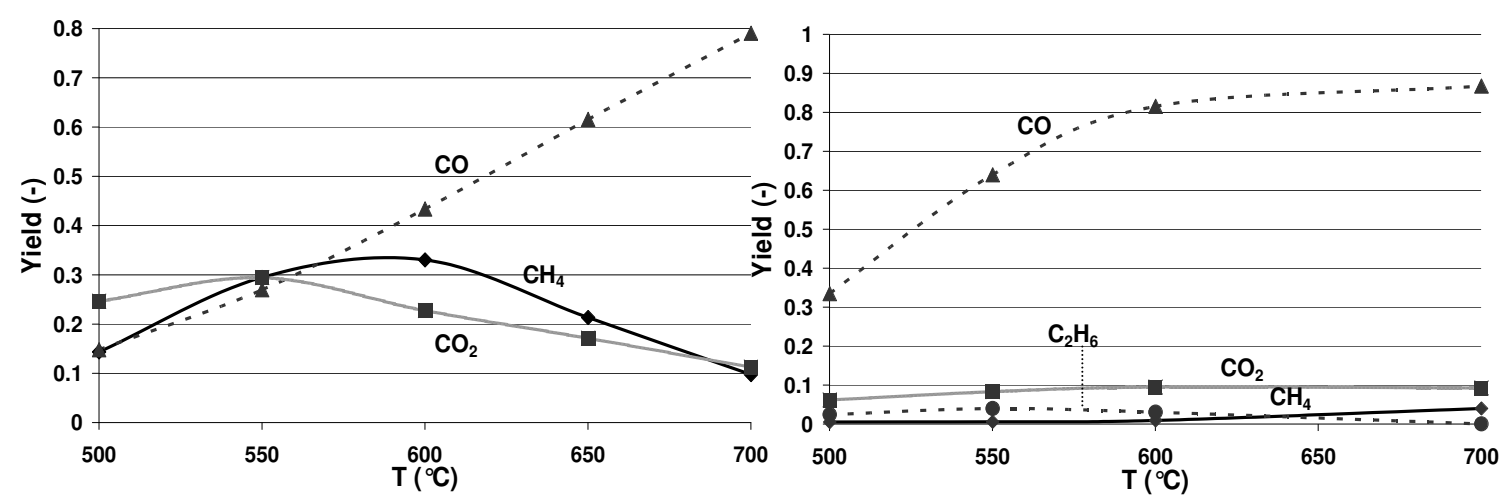

Figure 2.3: Yield of carbon containing products in ethane (left) and ethylene (right) steam reforming on $\mathrm{Rh} / \mathrm{YSZ}$ as a function of temperature

Related reactions were investigated to determine the reason for the production of methane in the ethane reforming experiment. Tests for methanation eq. (6+7) and hydrogenolysis eq. (8) reactions were carried out at $600^{\circ} \mathrm{C}$, since at this temperature the highest methane selectivity was obtained during steam reforming of ethane.

$$
\begin{aligned}
& \mathrm{CO}+3 \mathrm{H}_{2} \rightarrow \mathrm{CH}_{4}+\mathrm{H}_{2} \mathrm{O} \\
& \mathrm{CO}_{2}+4 \mathrm{H}_{2} \rightarrow \mathrm{CH}_{4}+2 \mathrm{H}_{2} \mathrm{O} \\
& \mathrm{C}_{2} \mathrm{H}_{6}+\mathrm{H}_{2} \rightarrow 2 \mathrm{CH}_{4}
\end{aligned}
$$


To investigate methanation on $\mathrm{Rh} / \mathrm{YSZ}$ a mixture of $\mathrm{CO}_{2}$ (10vol.\%), $\mathrm{H}_{2} \mathrm{O}$ (12vol.\%) and $\mathrm{H}_{2}(20 \mathrm{vol} . \%)$ was fed. Hardly any methane was formed in this case, as shown in Figure 2.4 in the left bar. Only $1 \%$ yield was obtained. The main product was 3 vol.\% of $\mathrm{CO}$, with still $17 \mathrm{vol} \%$ of hydrogen remaining (not shown). Thermodynamic calculations showed an equilibrium yield of methane of $1.7 \%$ under the present conditions.

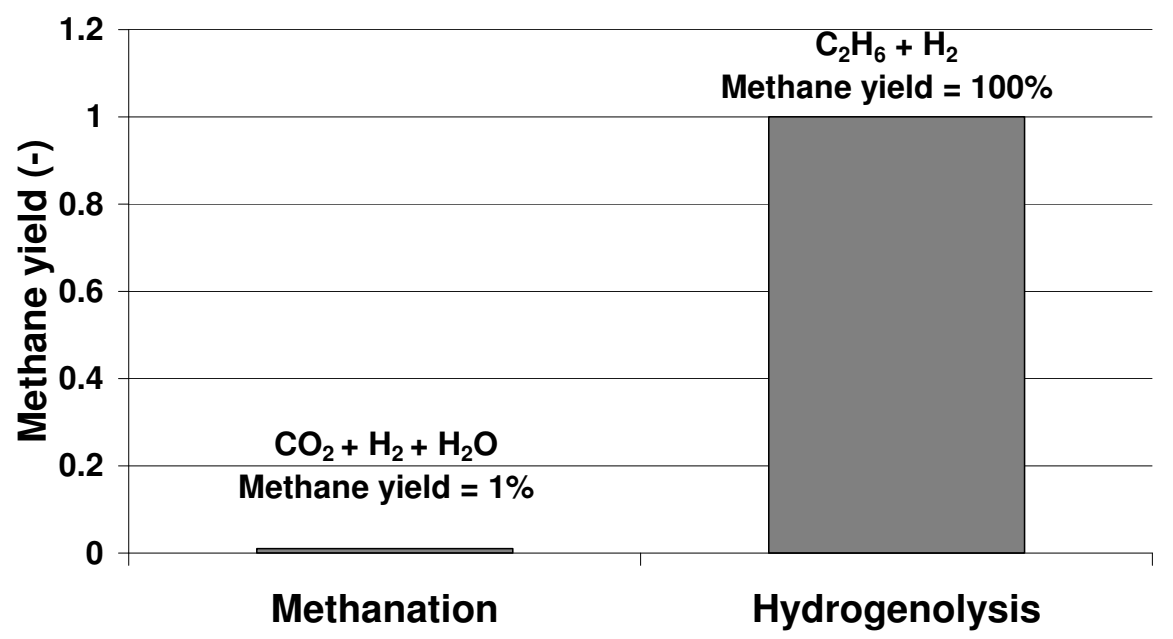

Figure 2.4: Comparison of methane yield in methanation and ethane hydrogenolysis tests at $\mathrm{600}^{\circ} \mathrm{C}$ on $\mathrm{Rh} / \mathrm{YSZ}$ at initial stage

During steam reforming reactions initially no hydrogen is present. Testing of hydrogenolysis reaction is however relevant as steam reforming of ethane will lead to hydrogen and $\mathrm{CO}_{\mathrm{x}}$, possibly enabling hydrogenolysis of ethane with hydrogen as a consecutive reaction. Moreover Rh-catalysts are well known to catalyze hydrogenolysis of ethane at temperatures around $300^{\circ} \mathrm{C}[21] ; \mathrm{Rh} / \mathrm{YSZ}$ is tested here at $600^{\circ} \mathrm{C}$.

Hydrogenolysis activity of Rh/YSZ was determined by feeding a $\mathrm{H}_{2}$ (20vol.\%) / ethane (5vol.\%) mixture. At $600^{\circ} \mathrm{C}$ complete conversion of ethane to methane was observed (right bar in Figure 2.4) initially. After a short period of complete conversion, fast deactivation occurred and within two hours $\mathrm{CH}_{4}$-yield dropped to $68 \%$ (not shown). This deactivation can be ascribed to coke formation on the catalyst, 
as regeneration of the catalyst was possible by heating the catalyst to $850^{\circ} \mathrm{C}$ in a 20vol.\% $\mathrm{O}_{2} /$ Ar-mixture (not shown).

Also the influence of hydrogenolysis under reforming reaction conditions was studied. Therefore a combined steam reforming/hydrogenolysis experiment was carried out. $5 \mathrm{vol} . \%$ of ethane, $20 \mathrm{vol} . \%$ of $\mathrm{H}_{2}$ and 12 vol. $\%$ of $\mathrm{H}_{2} \mathrm{O}$ in $\mathrm{Ar}$ were fed at $600^{\circ} \mathrm{C}$. The results of this experiment are shown in Figure 2.5 (left bars). The experiment initially shows a methane yield of $54 \%$ while $\mathrm{CO}_{\mathrm{x}}$ yield was $44 \%$. For comparison, $\mathrm{CO}_{\mathrm{x}}$ and methane yields in the normal reforming experiment (no addition of $\mathrm{H}_{2}$, as shown in Figure 2.1) are included in Figure 2.5 (right bar). It shows that adding hydrogen clearly increases the methane production at the expense of the synthesis gas yield.

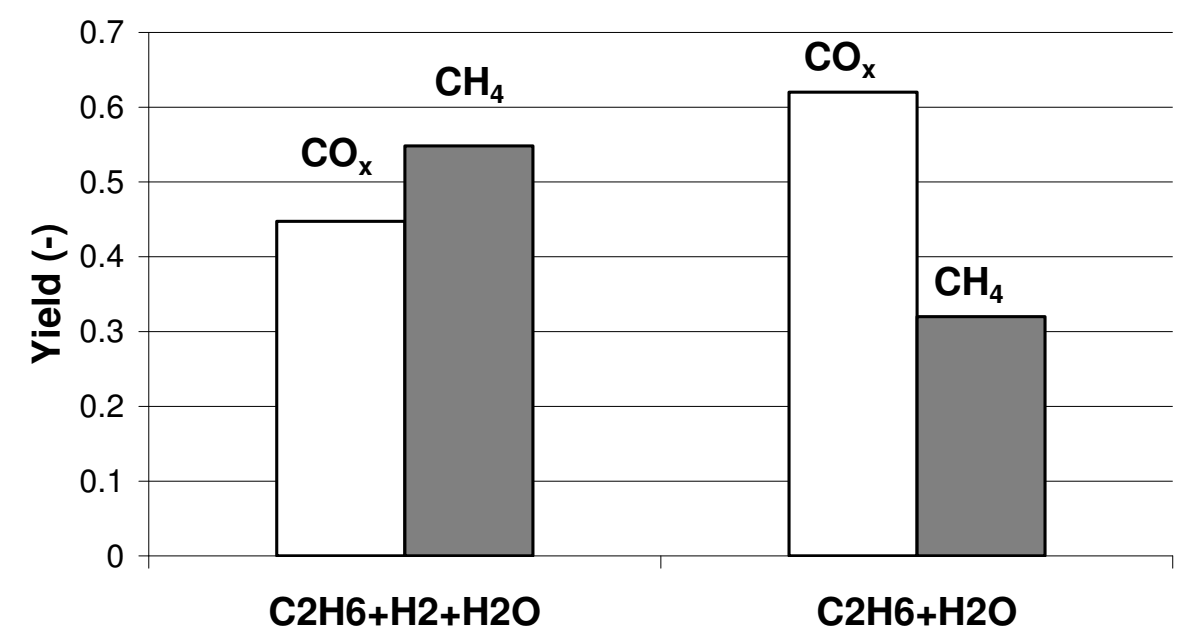

Figure 2.5: Yield of $\mathrm{CO}_{\mathrm{x}} /$ methane in a combined ethane steam reforming/ethane hydrogenolysis experiment at $600^{\circ} \mathrm{C}$ (left side), yield of $\mathrm{CO}_{\mathrm{x}} /$ methane in ethane steam reforming at $600^{\circ} \mathrm{C}$ (right side)

In addition, stability of the combined hydrogenolysis next to steam reforming of ethane was tested for 20 hours (not shown). Only a slight deactivation is observed for hydrogenolysis, as $\mathrm{CH}_{4}$ yield decreased from $54 \%$ to $51 \%$. During the entire reaction period the $\mathrm{CO}_{\mathrm{x}}$ yield remains constant at $44 \%$. This shows that ethane reforming and hydrogenolysis are stable processes under these conditions. 


\section{Comparative study of reforming of methane, ethane and ethylene}

\subsubsection{Pt/YSZ}

$\mathrm{Pt} / \mathrm{YSZ}$ was tested for steam reforming of methane, ethane and ethylene. The results are shown in Figure 2.6. On this catalyst methane shows the highest conversion under all conditions measured. Ethane and ethylene show similar conversions between $500^{\circ} \mathrm{C}$ and $600^{\circ} \mathrm{C}$, while ethylene conversion is slightly lower at higher temperatures. It should be noted that this catalyst showed no deactivation for all three hydrocarbons over the entire temperature range. In all reactions tested on $\mathrm{Pt} / \mathrm{YSZ}$ only $\mathrm{CO}, \mathrm{H}_{2}$ and $\mathrm{CO}_{2}$ were produced; no methane or ethane was formed.

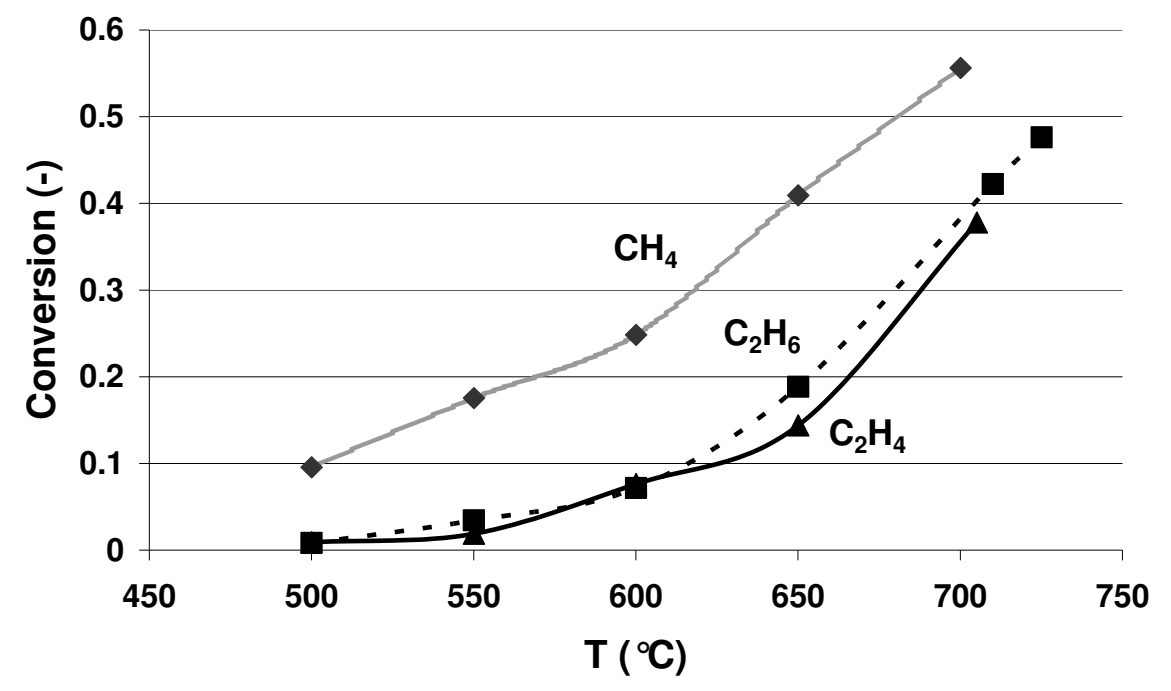

Figure 2.6: Conversion of methane (10vol.\%), ethane (5vol.\%) and ethylene (5vol.\%) when fed separately in steam reforming on Pt/YSZ as a function of temperature 
The water gas shift equilibrium was calculated and compared to the theoretical value for all experiments with Pt/YSZ (Figure 2.7). On the WGS reaction, it can be

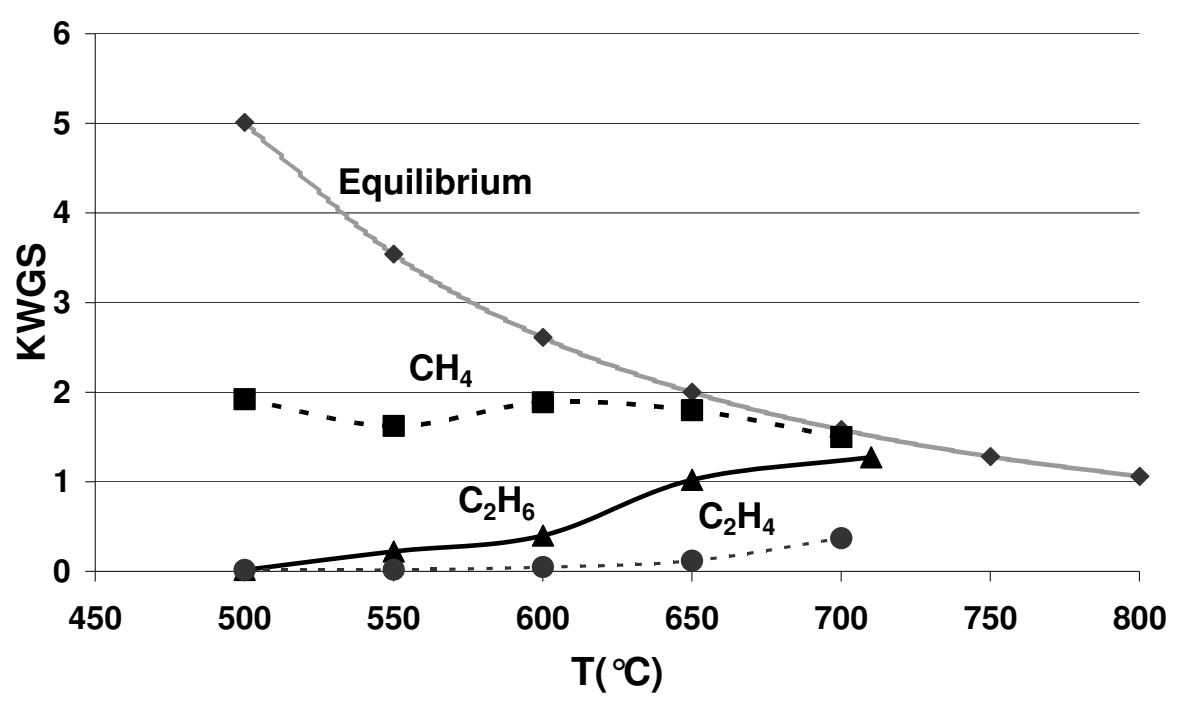

Figure 2.7: WGS equilibrium values between $500^{\circ} \mathrm{C}$ and $800^{\circ} \mathrm{C}$ compared to calculated WGS constants for steam reforming of methane, ethane and ethylene on Pt/YSZ. Conditions: 1vol.\% $\mathrm{CO}$ in Ar, 12 vol.\% of $\mathrm{H}_{2} \mathrm{O}$

concluded that equilibrium is only reached at temperatures above $650^{\circ} \mathrm{C}$ during methane reforming. In the case of ethane reforming, the amount of $\mathrm{CO}$ is higher than expected based on the WGS equilibrium, as indicated by a lower value for $\mathrm{K}$ compared to the equilibrium value. In the case of ethylene, almost only $\mathrm{CO}$ is formed, leading to K-values far from the equilibrium.

In addition, water gas shift experiments were performed to clarify the role of the hydrocarbons in the limitation to reach WGS equilibrium. A mixture of $\mathrm{CO}$ and $\mathrm{H}_{2} \mathrm{O}$ in $\mathrm{Ar}$ was used to determine activity for WGS between $500^{\circ} \mathrm{C}$ and $700^{\circ} \mathrm{C}$. The water gas shift constants calculated from experimental concentrations as compared to theoretical equilibrium constants are displayed in Figure 2.8a. Equilibrium was obviously reached between $500^{\circ} \mathrm{C}$ and $700^{\circ} \mathrm{C}$. To test the influence of ethylene, 5 vol.\% of ethylene was added to the $\mathrm{CO} / \mathrm{H}_{2} \mathrm{O}$ mixture at $700^{\circ} \mathrm{C}$. Immediately the conversion of $\mathrm{CO}$ to $\mathrm{CO}_{2}$ decreased significantly, suggesting that ethylene prevents equilibration of the WGS reaction (Figure 2.8b). Going back to the initial conditions (switching off ethylene) led to recovery of WGS activity and equilibrium was again achieved. 

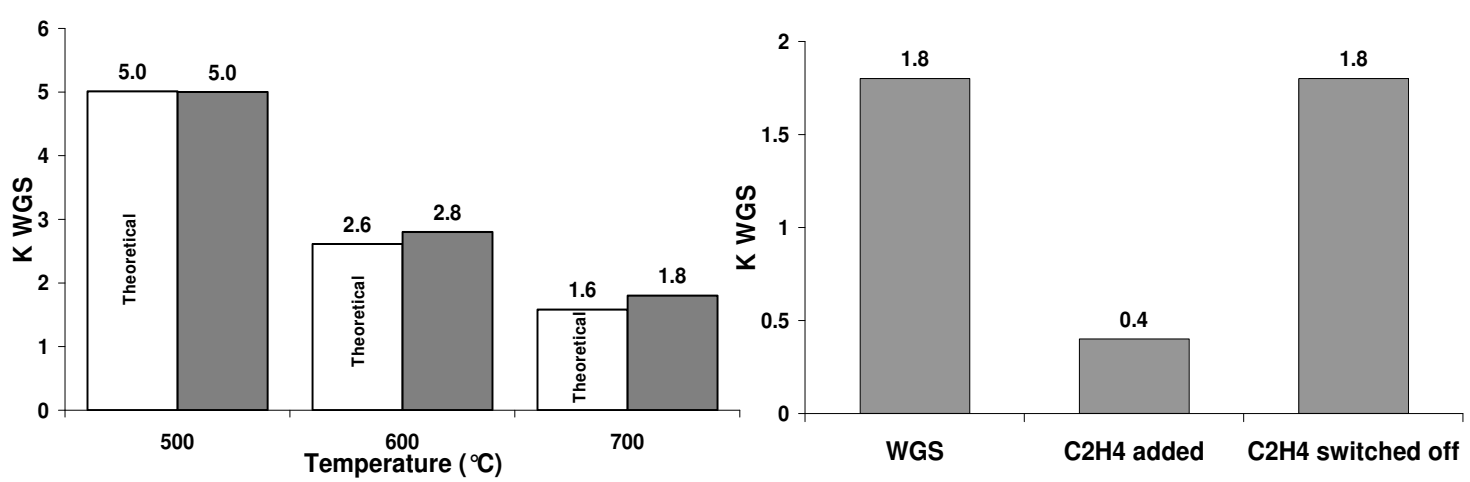

Figure 2.8 Left side (a): WGS equilibrium values (white bars) between $500^{\circ} \mathrm{C}$ and $7^{\circ} 0^{\circ} \mathrm{C}$ compared to calculated WGS constants for WGS experiments on Pt/YSZ (grey bars). Right side (b): effect of ethylene addition to WGS constant calculated from experimental data at $700^{\circ} \mathrm{C}$

Next to behaviour of separate components as described above reactivity of hydrocarbons in mixtures was investigated. Steam reforming of a mixture of methane (5vol.\%) and ethylene (2.5vol.\%) was tested on PtYSZ to test competition effects of both hydrocarbons. The conversions of methane and ethylene are shown in Figure 2.9. It can be observed that ethylene strongly affects conversion of methane on PtYSZ: conversion of methane is limited to less than $10 \%$ in presence of ethylene under all conditions.

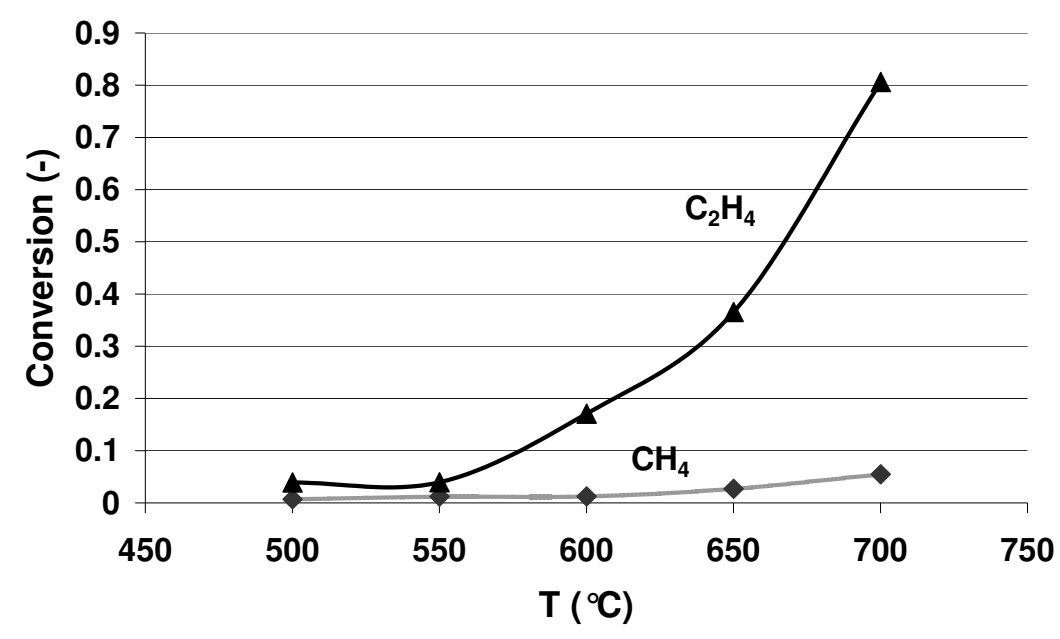

Figure 2.9: Conversions of methane (5vol.\%) and ethylene (2.5vol.\%) in mxture in steam reforming on PtYSZ 


\subsubsection{Pd/YSZ}

Ethane reforming was carried out on $\mathrm{Pd} / \mathrm{YSZ}$. Immediate deactivation occurred when operating at $5 \mathrm{vol} \%$ ethane at $600^{\circ} \mathrm{C}$. In Figure 2.10, the ethane conversion is shown as a function of time on-stream. Conversion of ethane dropped from $38 \%$ to around $11 \%$ during the first three hours. The pressure drop over the reactor increased from 0.1 to 0.35 bar and the catalyst appeared strongly coked. In experiments with methane, $\mathrm{Pd} / \mathrm{YSZ}$ showed stable conversion at temperatures from $500^{\circ} \mathrm{C}$ to $700^{\circ} \mathrm{C}$ (not shown).

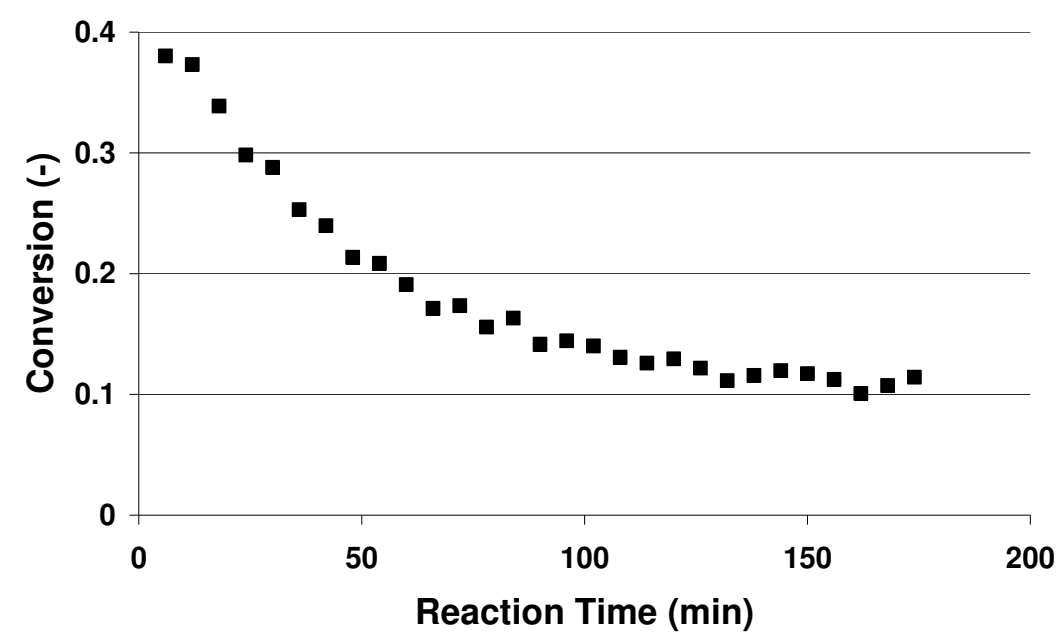

Figure 2.10: Conversion of ethane (5vol.\%) in steam reforming on $\mathrm{Pd} / \mathrm{YSZ}$ at $600^{\circ} \mathrm{C}$

Reforming of ethane on Pd/YSZ led to complete blocking of the reactor. The same observation was made by Hegarty et al [22] after reforming of methane for 30 hours with higher water/carbon ratio. As ethane causes coking, experiments with ethylene would not make sense as ethylene usually leads to even faster formation of coke [9]. The high coking tendency eliminates Pd as reforming catalyst for combined methane coupling/steam reforming process. No further experiments were carried out on this catalyst. 


\subsection{Discussion}

\subsubsection{Activity of hydrocarbons on Pt and Rh}

The comparative study of methane, ethane and ethylene steam reforming on $\mathrm{Pt}, \mathrm{Rh}$ and Pd on YSZ shows large differences in both reactivity as well as product slate. The order of activity of $\mathrm{Pt} / \mathrm{YSZ}$ was $\mathrm{CH}_{4}>\mathrm{C}_{2} \mathrm{H}_{6} \approx \mathrm{C}_{2} \mathrm{H}_{4}$ (Figure 2.6). Interestingly, on $\mathrm{Rh} / \mathrm{YSZ}$ the order of activity was completely different: $\mathrm{C}_{2} \mathrm{H}_{6}>\mathrm{C}_{2} \mathrm{H}_{4}>\mathrm{CH}_{4}$ (Figure 2.1). Figure 2.10a illustrates that $\mathrm{Rh} / \mathrm{YSZ}$ is much more active for ethylene reforming as compared to Pt/YSZ; for ethane a similar result is obtained (not shown). The conversion of methane on both $\mathrm{Pt} / \mathrm{YSZ}$ and $\mathrm{Rh} / \mathrm{YSZ}$ catalysts is shown in Figure $2.11 \mathrm{~b}$. The difference in conversion of methane on both catalysts is much smaller than in case of ethylene or ethane
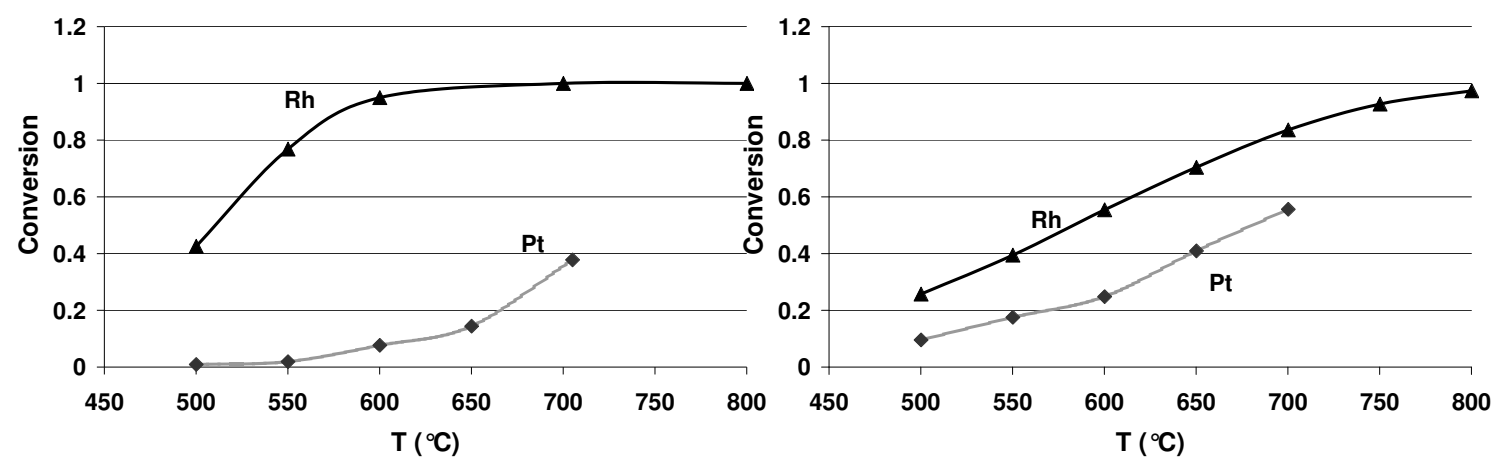

Figure 2.11: Comparison of conversion of ethylene (5vol.\%) (a) and conversion of methane (10vol.\%) (b) in steam reforming on Pt/YSZ and Rh/YSZ

The C2-hydrocarbons were converted much easier on $\mathrm{Rh}$ as complete conversion was observed already at $600^{\circ} \mathrm{C}$ (Figure 2.1). It is obvious that the differences between both metals cannot be explained by difference in metal dispersion (Table 2.1), since for both catalysts the metal particles are large, ruling out an ensemble effect. The high reactivity of $\mathrm{Rh}$ towards $\mathrm{C} 2$ hydrocarbons relates to findings in literature. $\mathrm{Rh}$ shows a higher binding strength towards carbon atoms than Pt, indicating a higher reactivity in C-C scission reactions [17].

Van Broekhoven and Ponec [19] related the reactivity of several metals towards higher hydrocarbons to the tendency to form multiple bonds between one carbon atom and the metal. It is stated that easy formation of multiple metal carbon bonds can be 
correlated to higher activity in C-C splitting reactions. While rhodium is one of the better metals in this respect, $\mathrm{Pt}$ is inactive. This explains the observations in the present research, that $\mathrm{Rh}$ is more active than $\mathrm{Pt}$ in ethane and ethylene reforming. $\mathrm{Pt} / \mathrm{YSZ}$ was the most stable catalyst. Pd/YSZ suffered from severe deactivation because of coking, while Rh/YSZ showed deactivation by coking only during ethylene reforming at temperatures below $600^{\circ} \mathrm{C}$.

For the purpose of developing steam reforming catalysts which are able to convert selectively methane in hydrocarbon mixtures with ethane and ethylene, further research will be focused on Pt-catalysts. It was shown in Figure 2.9 that presence of ethylene can limit conversion of methane significantly. Similar to the water gas shift reaction (section 4.2), a blocking effect was noticed in this case. The strong adsorption of ethylene leads to low surface coverage of methane and low reaction rates of methane. Methane conversion was limited to less than $10 \%$ indicating that almost no methane adsorption on the catalyst is possible. In chapter 3 of this thesis, potassium will be added to Pt steam reforming catalysts and the effects to conversions of the hydrocarbons when fed in mixtures will be studied.

\subsubsection{WGS equilibrium}

The water gas shift equilibrium is achieved on $\mathrm{Rh} / \mathrm{YSZ}$ during reforming of methane and ethane (Figure 2.2). This agrees with the results reported by Wei et al. [23], claiming that WGS is equilibrated during steam reforming of methane on supported metal catalysts. In the present study, too much $\mathrm{CO}$ was formed compared to $\mathrm{CO}_{2}$ in case of ethylene, suggesting partial hindering of WGS during reforming of ethylene. On Pt/YSZ the equilibrium is only reached for methane at temperatures higher than $650^{\circ} \mathrm{C}$ (Figure 2.7). In reforming of C2-hydrocarbons and especially ethylene, the amount of $\mathrm{CO}$ is much too high as compared to the water gas shift equilibrium. Probably, CO adsorption on the metal surface is surpressed, as water activation is obviously still taking place because steam reforming and WGS both need activation of water. Possibly, adsorption of CO is hindered by strongly adsorbed ethylene and ethane fragments. This indicates that carbon deposits can be involved during steam reforming. 
The WGS reaction achieved equilibrium on $\mathrm{Pt}$ between $500^{\circ} \mathrm{C}$ and $700^{\circ} \mathrm{C}$ (Figure 2.8a) in the absence of hydrocarbons, while this was not the case during steam reforming experiments. The fact that water gas shift reaction equilibrated immediately when ethylene was switched off (Figure 2.8b) demonstrates that blocking by ethylene is fully reversible at $700^{\circ} \mathrm{C}$. It can be concluded that ethylene blocks sites on the metal surface and that the responsible (hydro-)carbon fragments are easily removed.

\subsubsection{Mechanism of steam reforming of ethane on $\mathrm{Rh}$}

The results on Rh/YSZ provide new insights in the mechanisms involved during steam reforming of ethane. While on Pt/YSZ only reforming reactions occurred, surprisingly methane was one of the major products in case of ethane reforming on $\mathrm{Rh} / \mathrm{YSZ}$. In literature, it is assumed that the methane formation in reforming of higher hydrocarbons occurs through methanation reactions [24, 25]. In this study, however, tests of methanation reactions on $\mathrm{Rh} / \mathrm{YSZ}$ show that essentially only the WGS reaction occurs; $\mathrm{CO}_{2}$ and hydrogen are converted into $\mathrm{H}_{2} \mathrm{O}$ and $\mathrm{CO}$. Only a small amount of $\mathrm{CH}_{4}\left(1 \%\right.$ as shown in Figure 2.4) was detected at $600^{\circ} \mathrm{C}$. This result excludes $\mathrm{CO}_{2}$ methanation (equation (7)) as a source of methane during reforming. In addition, the final product composition, containing 3 vol. $\% \mathrm{CO}$ and $17 \mathrm{vol} \% \mathrm{H}_{2}$, also proves that methanation with $\mathrm{CO}$ (equation (6)) is not significantly contributing under these conditions. Consequently, it can be concluded that neither methanation of $\mathrm{CO}_{2}$ nor $\mathrm{CO}$ is responsible for methane formation during ethane reforming, where methane yields up to $30 \%$ were found.

However, hydrogenolysis tests at $600^{\circ} \mathrm{C}$ showed that ethane and hydrogen (under conditions comparable to reforming) were converted to methane completely (Figure 2.4). This is a strong indication that methane formation is due to hydrogenolysis during ethane steam reforming. Nevertheless, fast deactivation of $\mathrm{Rh} / \mathrm{YSZ}$ was observed during ethane hydrogenolysis, while methane formation was constant with time on stream during ethane steam reforming experiments on the same catalyst. The combined hydrogenolysis/reforming experiment (Figure 2.5) indicates that the deactivation of the catalyst is much slower in presence of water and that high methane concentrations can be detected for several hours. From this, it is proposed that the presence of water limits coke formation on the $\mathrm{Rh}$ surface and a stable conversion 
level of ethane to methane is obtained. Generally, it is well a known [9] that presence of steam is favorable to avoid coke formation.

Addition of hydrogen in the combined experiment increased the methane yield as compared to the standard ethane reforming experiment (Figure 2.5). Hydrogenolysis can occur throughout the reactor when hydrogen is added to the feed. During ethane reforming however, hydrogenolysis is only possible after hydrogen is produced from ethane and water. Therefore, addition of hydrogen to the feed significantly increases the methane yield. Furthermore, it can be concluded that ethane hydrogenolysis contributes as a consecutive reaction during ethane steam reforming on $\mathrm{Rh} / \mathrm{YSZ}$ as schematically shown in scheme 2.1. Methanation does not significantly contribute to the production of methane (Figure 2.4), in contrast to propositions in literature [24, 25]. The conclusions on the reaction network based on experimental evidence are in full agreement with thermodynamics. Ethane and hydrogen can be completely converted to methane between $300^{\circ} \mathrm{C}$ and $800^{\circ} \mathrm{C}$. In contrast, equilibrium yield of methanation is only $1.7 \%$ at $600^{\circ} \mathrm{C}$, confirming that methanation is not significantly contributing.

\section{Steam reforming}

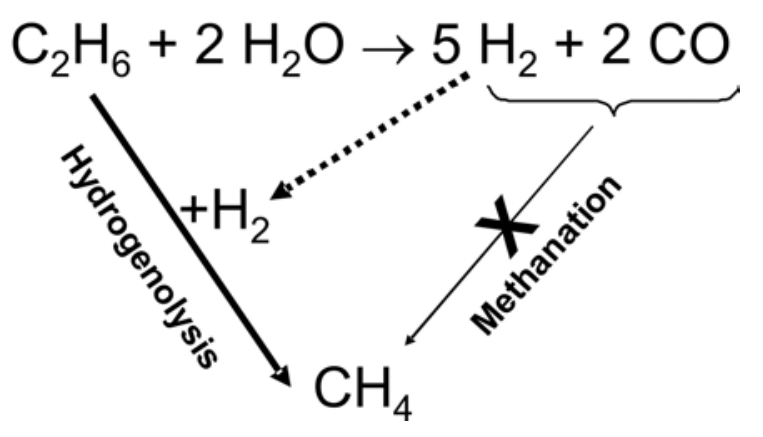

Scheme 2.1: Reactions taking place during ethane steam reforming on Rh/YSZ 


\subsection{Conclusion}

This comparative study of methane, ethane and ethylene steam reforming on $\mathrm{Pt}, \mathrm{Rh}$ and Pd on YSZ shows substantial differences between the catalytic properties of the metals. Both reactivity and composition of products vary. The order of activity on Rh was $\mathrm{C}_{2} \mathrm{H}_{6}>\mathrm{C}_{2} \mathrm{H}_{4}>\mathrm{CH}_{4}$. On $\mathrm{Pt}$, methane reacted faster than the $\mathrm{C} 2$ hydrocarbons: $\mathrm{CH}_{4}>\mathrm{C}_{2} \mathrm{H}_{6} \approx \mathrm{C}_{2} \mathrm{H}_{4}$. Concerning the target process of methane coupling combined with reforming, $\mathrm{Pt}$ is considered the most promising metal because $\mathrm{C} 2$ hydrocarbons are converted less then methane. Additionally, Pt/YSZ is the most stable catalyst. When fed in mixture with ethylene methane conversion was limited on PtYSZ.

On Pt/YSZ, the steam reforming reactions resulted in synthesis gas exclusively. However, more importantly, in this study all the occurring reactions during ethane steam reforming on Rh/YSZ have been elucidated. Additionally to synthesis gas, methane was formed during steam reforming of ethane on Rh/YSZ. It was shown that hydrogenolysis of ethane occurred on this catalyst as a consecutive reaction, converting hydrogen produced in ethane steam reforming via hydrogenolysis of unconverted ethane. This shows that effective steam reforming of higher hydrocarbons can only be achieved when the activity for hydrogenolysis is also considered to avoid production of methane. 


\subsection{References}

[1] M. Makri, C.G. Vayenas, Applied Catalysis A-General 244 (2003) 301.

[2] V.R. Choudhary, B.S. Uphade, Catalysis Surveys from Asia 8 (2004) 15.

[3] Istadi, N.A.S. Amin, Fuel 85 (2006) 577-592.

[4] N. Lapena-Rey, P.H. Middleton, Applied Catalysis A-General 240 (2003) 207.

[5] H. Zhang, J. Wu, B. Xu, C. Hu, Catalysis Letters 106 (2006) 161.

[6] J.A. Hugill, F.W.A. Tillemans, J.W. Dijkstra, S. Spoelstra, Applied Thermal Engineering 25 (2005) 1259.

[7] A. Machocki, A. Denis, Chemical Engineering Journal 90 (2002) 165.

[8] D. Czechowicz, K. Skutil, A. Torz, M. Taniewski, Journal of Chemical Technology and Biotechnology 79 (2004) 182.

[9] D.L. Trimm, Catalysis Today 37 (1997) 233.

[10] X. Wang, R.J. Gorte, Applied Catalysis A-General 224 (2002) 209.

[11] T. Takeguchi, Y. Kani, T. Yano, R. Kikuchi, K. Eguchi, K. Tsujimoto, Y. Uchida, A. Ueno, K. Omoshiki, M. Aizawa, Journal of Power Sources 112 (2002) 588.

[12] D. Sutton, S.M. Parle, J.R.H. Ross, Fuel Processing Technology 75 (2002) 45.

[13] T. Sperle, D. Chen, R. Lodeng, A. Holmen, Applied Catalysis A-General 282 (2005) 195.

[14] O. Sidjabat, D.L. Trimm, Topics in Catalysis 11 (2000) 279.

[15] J.R. Rostrup-Nielsen, J.H.B. Hansen, Journal of Catalysis 144 (1993) 38-49.

[16] J.M. Wei, E. Iglesia, Journal of Physical Chemistry B 108 (2004) 4094.

[17] A.V. Zeigarnik, R.E. Valdes-Perez, O.N. Myatkovskaya, Journal of Physical Chemistry B 104 (2000) 10578.

[18] A.V. Zeigarnik, O.N. Myatkovskaya, Kinetics and Catalysis 42 (2001) 418.

[19] E.H.v. Broekhoven, V. Ponec, Progress in Surface Science 19 (1985) 351.

[20] K. Nagaoka, K. Seshan, K. Aika, J.A. Lercher, Journal of Catalysis 197 (2001) 34.

[21] L.D. Schmidt, K.R. Krause, Catalysis Today 12 (1992) 269.

[22] M.E.S. Hegarty, A.M. O'Connor, J.R.H. Ross, Catalysis Today 42 (1998) 225.

[23] J.M. Wei, E. Iglesia, Physical Chemistry Chemical Physics 6 (2004) 3754.

[24] G. Kolb, R. Zapf, V. Hessel, H. Lowe, Applied Catalysis A-General 277 (2004) 155.

[25] C. Resini, M.C.H. Delgado, L. Arrighi, L.J. Alemany, R. Marazza, G. Busca, Catalysis Communications 6 (2005) 441. 


\title{
Chapter 3
}

\section{Influence of potassium on the competition between methane and ethane in steam reforming over Pt supported on yttrium-stabilized zirconia}

\begin{abstract}
The effect of addition of potassium to Pt supported on yttrium-stabilized-zirconia (PtYSZ) catalyst for steam reforming of methane, ethane and methane/ethane mixtures was explored. Addition of potassium has a positive effect on preferential steam reforming of methane in mixtures of methane and ethane over PtYSZ catalysts. The activity of potassium modified catalysts increased with time-on-stream during steam reforming of mixtures of methane and ethane, while the ratio of reaction rates of methane and ethane remained constant. Most importantly, it was demonstrated that the presence of potassium prevents competition between methane and ethane during steam reforming. The reaction rate ratio in methane/ethane mixtures is changed from preferential ethane reforming on PtYSZ towards preferential methane conversion as a result of addition of potassium.
\end{abstract}




\subsection{Introduction}

Natural gas, mainly consisting of methane, is available in large quantities and is becoming one of the major resources for energy and chemicals. A new concept for utilization of methane is proposed in this study, as discussed in detail in earlier work [1]. Shortly, the intention is to combine oxidative coupling and inevitable combustion with reforming reactions of methane (equations (1) to (4)) in one multifunctional auto thermal reactor. This should lead to production of ethylene and synthesis gas in one auto thermal process, in which the energy released in reactions (1) and (2) is used to reform methane through reactions (3) and (4).

$$
\begin{aligned}
& \mathrm{CH}_{4}+1 / 2 \mathrm{O}_{2} \rightarrow 1 / 2 \mathrm{C}_{2} \mathrm{H}_{4}+\mathrm{H}_{2} \mathrm{O} \quad \Delta \mathrm{H}^{\circ}{ }_{298} \quad=-140 \mathrm{~kJ} / \mathrm{mol} \\
& \mathrm{CH}_{4}+2 \mathrm{O}_{2} \rightarrow \mathrm{CO}_{2}+2 \mathrm{H}_{2} \mathrm{O} \quad \Delta \mathrm{H}^{\circ}{ }_{298}=-801 \mathrm{~kJ} / \mathrm{mol} \\
& \mathrm{CH}_{4}+\mathrm{H}_{2} \mathrm{O} \rightarrow 3 \mathrm{H}_{2}+\mathrm{CO} \quad \Delta \mathrm{H}^{\circ}{ }_{298}=206 \mathrm{~kJ} / \mathrm{mol} \\
& \mathrm{CH}_{4}+\mathrm{CO}_{2} \rightarrow 2 \mathrm{H}_{2}+2 \mathrm{CO} \quad \Delta \mathrm{H}^{\circ}{ }_{298}=247 \mathrm{~kJ} / \mathrm{mol}
\end{aligned}
$$

For the complete process, two catalysts are needed, one for oxidative coupling and one for the reforming reaction. The main focus in the current work is on the reforming steps $(3+4)$ of the mixture produced in the oxidative coupling. In addition to ethylene, also ethane is produced during oxidative methane coupling. The oxidative coupling reaction thus leads to a mixture of unreacted methane and produced ethane and ethylene, plus $\mathrm{CO}, \mathrm{CO}_{2}$ and $\mathrm{H}_{2} \mathrm{O}$ from the combustion reaction.

Due to the high temperature necessary for oxidative coupling $\left(700^{\circ} \mathrm{C}\right)$, most of the $\mathrm{CO}_{2}$ reacts to $\mathrm{CO}$ through the reversed water gas shift reaction, producing water next to $\mathrm{CO}$. Therefore, the $\mathrm{H}_{2} \mathrm{O}$ concentration will be much higher than the $\mathrm{CO}_{2}$ concentration, making the steam reforming reaction (3) more relevant than the dry reforming reaction (4).

Steam reforming of the product stream from oxidative coupling leads to competition between methane, ethane and ethylene. All these hydrocarbons can be easily steamreformed [2]. The main challenge in this project is, therefore, to prevent or limit the steam reforming of ethane and ethylene, while methane should be effectively 
converted. The relevant temperature window is between $700^{\circ} \mathrm{C}$ and $800^{\circ} \mathrm{C}$, because of the integrated operation of oxidative coupling.

Pt supported on zirconia proved to be a stable catalyst in steam and dry reforming of methane [3-6]. In earlier research [1], Pt supported on yttrium stabilized zirconia (YSZ) was found to be the most suitable metal catalyst for steam reforming of single reactants. Compared to $\mathrm{Rh}$ and $\mathrm{Pd}$, PtYSZ showed the highest relative activity towards methane, for separate reforming of methane, ethane and ethylene. The relatively low reactivity of $\mathrm{Pt}$ towards ethane was in agreement with earlier results by Sinfelt et al. [7-9], reporting low activity of Pt in ethane hydrogenolysis, as compared to $\mathrm{Rh}$. It was also found that methane hardly reacted in steam reforming when mixed with ethylene, which was attributed to strongly adsorbed ethylene fragments blocking the active Pt sites. Also carbon formation is an issue in steam reforming of ethylene $[1,2]$.

In literature, it is claimed that $\mathrm{K}$ prevents carbon formation on $\mathrm{Ni}$ catalysts by blocking step sites which are believed to be the nucleation sites for graphite formation [10]. In addition, potassium present on $\mathrm{Ni}$ catalysts enhances coke gasification [11]. For $\mathrm{Ni} / \mathrm{Al}_{2} \mathrm{O}_{3}$, Juan-Juan et al [12] found decreasing activity in methane dry reforming with increasing potassium concentration in the catalyst. A reduction in catalytic activity by potassium was also confirmed by Trimm [13] and Rostrup-Nielsen [14]. The activity of $\mathrm{Ni} / \mathrm{MgO}-\mathrm{Al}_{2} \mathrm{O}_{3}$ for methane steam reforming was reported to decrease by $85 \%$ when $1.1 \mathrm{wt} \%$ of $\mathrm{K}$ was added [15]. In short, addition of $\mathrm{K}$ to $\mathrm{Ni}$ catalyst decreases steam reforming activity and limits carbon formation and deactivation. Decreasing reforming activity by addition of potassium was also found on $\mathrm{Rh} / \mathrm{La}-\mathrm{Al}_{2} \mathrm{O}_{3}[16]$.

However, the effect of potassium on Pt catalysts on steam reforming of methane and ethane has not been reported so far. This study explores the effect of $\mathrm{K}$ addition to PtYSZ on catalyst activity and stability, for steam reforming of both ethane and methane as well as ethane/methane mixtures. 


\subsection{Experimental}

Yttrium stabilized zirconia (YSZ), obtained from TOSOH (TZ-8Y) was used as support and was modified with 2 and 4wt.\% potassium. 15g of YSZ was impregnated with $15 \mathrm{ml}$ of an aqueous $\mathrm{K}_{2} \mathrm{CO}_{3}$ solution, containing resp. 0.5 or $1 \mathrm{~g}$ of $\mathrm{K}_{2} \mathrm{CO}_{3}$ and calcined in synthetic air $\left(30 \mathrm{ml} / \mathrm{min}\right.$ ) for 4 hours at $600^{\circ} \mathrm{C}$ (temperature ramp $\left.5^{\circ} \mathrm{C} \min ^{-1}\right)$.

Subsequently, $1 \mathrm{wt} \%$ of $\mathrm{Pt}$ was impregnated on $10 \mathrm{~g}$ of support with a $\mathrm{H}_{2} \mathrm{PtCl}_{6}$ (Alfa Aesar) solution containing $0.01 \mathrm{~g}$ Pt per ml aqueous solution. PtYSZ was calcined at $750^{\circ} \mathrm{C}$. The potassium modified samples were calcined at two different temperatures, $700^{\circ} \mathrm{C}$ and $750^{\circ} \mathrm{C}$ respectively. Catalysts were calcined in synthetic air $(30 \mathrm{ml} / \mathrm{min})$ during $15 \mathrm{~h}$ (ramp $5^{\circ} \mathrm{C} \mathrm{min}^{-1}$ ). Next to PtYSZ, four potassium modified catalysts were prepared, designated by initial potassium content (wt.\%) and calcination temperature: Pt2K700, Pt2K750, Pt4K700 and Pt4K750.

Activity tests were carried out in a micro reactor flow setup. The reactor consisted of a quartz tube with inner and outer diameter of respectively 4 and $6 \mathrm{~mm}$. 200mg of catalyst was loaded between quartz wool plugs. Catalyst particles with a diameter between 0.3 and $0.6 \mathrm{~mm}$ were used, resulting in a pressure drop around 0.1 bar. The samples were heated to $500^{\circ} \mathrm{C}$ in argon and reduced in $2.5 \mathrm{vol} . \% \mathrm{H}_{2}$ (Indugas 5.0) / $\mathrm{Ar}$ for $1 \mathrm{~h}$ (flow rate: $200 \mathrm{ml} / \mathrm{min}$ ) before measuring the catalytic performance. No significant activity for steam reforming of methane and ethane was found for the support material $\mathrm{YSZ}$ at $700^{\circ} \mathrm{C}$. Also the occurrence of gas phase reactions could be excluded based on experiments with quartz particles of 0.3 to $0.6 \mathrm{~mm}$.

Methane (Hoekloos 4.5) and ethane (Indugas 4.0) were mixed with argon (Hoekloos 5.0) to a total flow rate of $200 \mathrm{ml} \cdot \mathrm{min}^{-1}$, to ensure a constant space velocity In the first series of experiments $2.2 \mathrm{vol} \%$ of ethane and $5 \mathrm{vol} . \%$ of methane were used at a reaction temperature of $700^{\circ} \mathrm{C}$. For comparison, identical concentrations were also applied separately in additional experiments with a single hydrocarbon. In the second series of experiments, methane and ethane concentrations and ratios were varied.

Water was added to the gas mixtures via a double saturation step: the gas stream was bubbled through water at $65^{\circ} \mathrm{C}$ in the first saturator, followed by condensation at $55^{\circ} \mathrm{C}$ 
in a second saturator. This led to a stable water concentration of $12 \mathrm{vol} . \%$, resulting in a water/carbon ratio above 1 for all experiments. The product and reactant gas composition was analyzed with a Varian 3800 Gas Chromatograph equipped with two columns (Molsieve 5A and PoraPlotQ) and two TCD detectors. Water was analyzed in the PoraPlotQ column; the molsieve column was protected against water by a PoraPlotQ pre-column and a backflush system.

Elemental composition of the catalysts was determined with XRF on a Philips PW 1480 X-ray spectrometer. 


\subsection{Results}

\subsubsection{Catalyst characterisation}

Table 3.1 shows the platinum and potassium contents of the samples as determined with XRF. The Pt content is similar for all catalysts and remained unchanged during reaction. The potassium content is shown for both fresh catalysts and after $20 \mathrm{~h}$ and $85 \mathrm{~h}$ time-on-stream (TOS). The initial content varies with calcination temperature: calcination at $700^{\circ} \mathrm{C}$ results in a higher potassium content than calcination at $750^{\circ} \mathrm{C}$. All catalysts lost potassium during reaction. However, analysis of Pt4K700 after 85 hours of testing showed that the potassium content remained stable after 20 hours TOS.

Table 3.1: Platinum and potassium contents of the applied catalysts as determined with XRF.

\begin{tabular}{|c|c|c|c|c|}
\hline Catalyst & Wt.\% Pt & $\begin{array}{c}\text { Wt.\% K } \\
\text { (initial) }\end{array}$ & $\begin{array}{c}\text { Wt.\% K } \\
(20 \mathrm{~h})\end{array}$ & $\begin{array}{c}\text { Wt.\% K } \\
(85 \mathrm{~h})\end{array}$ \\
\hline PtYSZ & $1.04 \pm 0.03$ & - & - & - \\
\hline Pt2K700 & $1.05 \pm 0.03$ & $1.05 \pm 0.03$ & $0.45 \pm 0.01$ & - \\
\hline Pt2K750 & $0.96 \pm 0.03$ & $0.77 \pm 0.02$ & $0.35 \pm 0.01$ & - \\
\hline Pt4K700 & $1.03 \pm 0.03$ & $2.05 \pm 0.06$ & $0.90 \pm 0.03$ & $0.90 \pm 0.03$ \\
\hline Pt4K750 & $1.01 \pm 0.03$ & $1.60 \pm 0.05$ & $0.85 \pm 0.03$ & - \\
\hline
\end{tabular}

\subsubsection{Activity testing}

The steam reforming activity was measured with a mixture of methane (5vol.\%) and ethane $(2.2 \mathrm{vol} . \%)$. The reaction rates for both methane and ethane for a 20 hour period TOS are shown in Figure 3.1. Figure 3.1A shows the results for the unmodified Pt supported on yttrium stabilised zirconia (YSZ). The maximum reaction rate for ethane and methane was found during the initial stage of the experiment and the catalyst deactivated with about $30 \%$ in $20 \mathrm{~h}$ for both reactants. The conversion at the initial stage was $70 \%$ for ethane and $28 \%$ for methane. The ratio between methane and ethane reaction rate remained constant at 0.81 . 

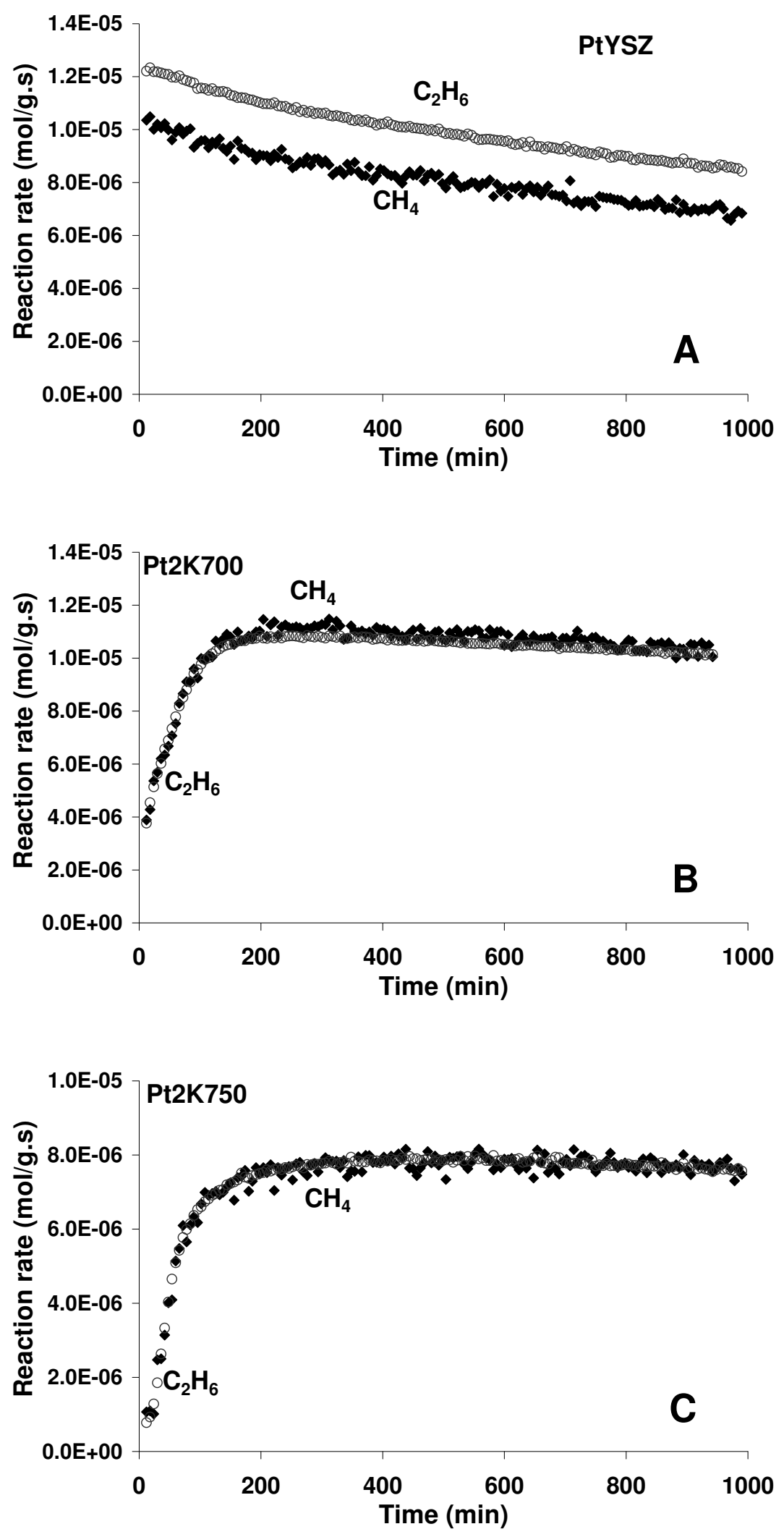

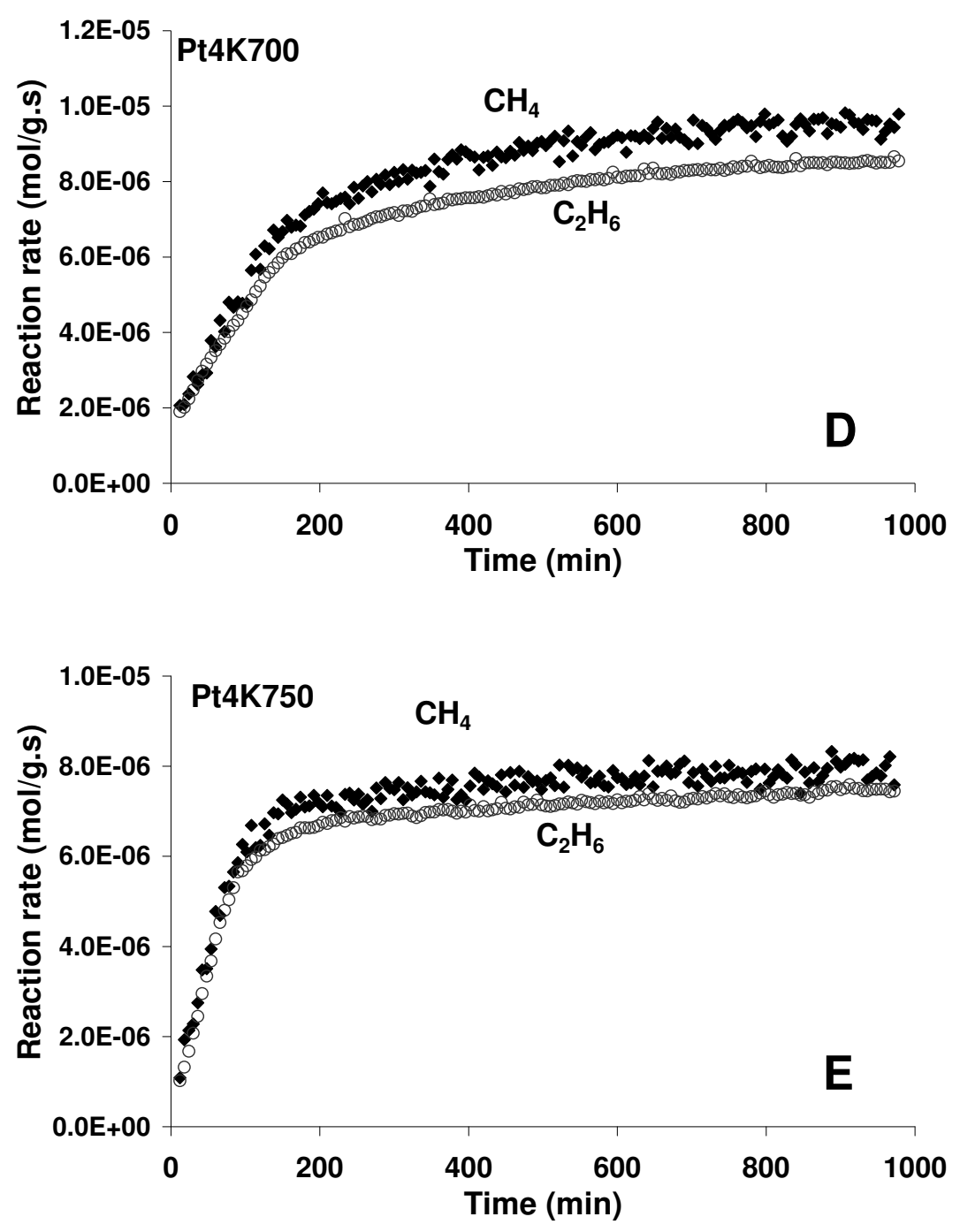

Figure 3.1: Reaction rates of a mixture of methane (४, 5vol.\%) and ethane $(\circ, 2.2 \mathrm{vol.} \%)$ in steam reforming on PtYSZ (A), Pt2K700 (B), Pt2K750 (C), Pt4K700 (D) and Pt4K750 (E)

Figure 3.1B to Figure 3.1E show the results of the steam reforming experiments with the methane/ethane mixture on the potassium-modified catalysts. These four catalysts showed a low initial activity for both reactants, but activity significantly increased during several hours. This phenomenon will be referred to as "activation" in the remainder of this paper.

The samples with the lower potassium amounts, namely Pt2K700 and Pt2K750 (Figure 3.1B and Figure 3.1C), activated within 200 minutes. After activation, methane and ethane reaction rates were fairly constant. A $10 \%$ decrease in the reaction rate in the final 800 minutes was noticed in the case of $\mathrm{Pt} 2 \mathrm{~K} 700$ (Figure 3.1B), while Pt2K750 (Figure 3.1C) showed a stable activity. The reaction rates 
measured on Pt4K700 and Pt4K750 are shown in Figure 3.1D and Figure 3.1E. The activation for these two catalysts took longer, especially in case of Pt4K700, observing increasing activity during 1000 minutes. Continuation of the experiment for another 600 minutes showed no further changes in reaction rates (not shown). No deactivation was observed for both Pt4K700 and Pt4K750. The conversions of methane and ethane at maximum activity for Pt4K700 were $24 \%$ and $48 \%$, respectively.

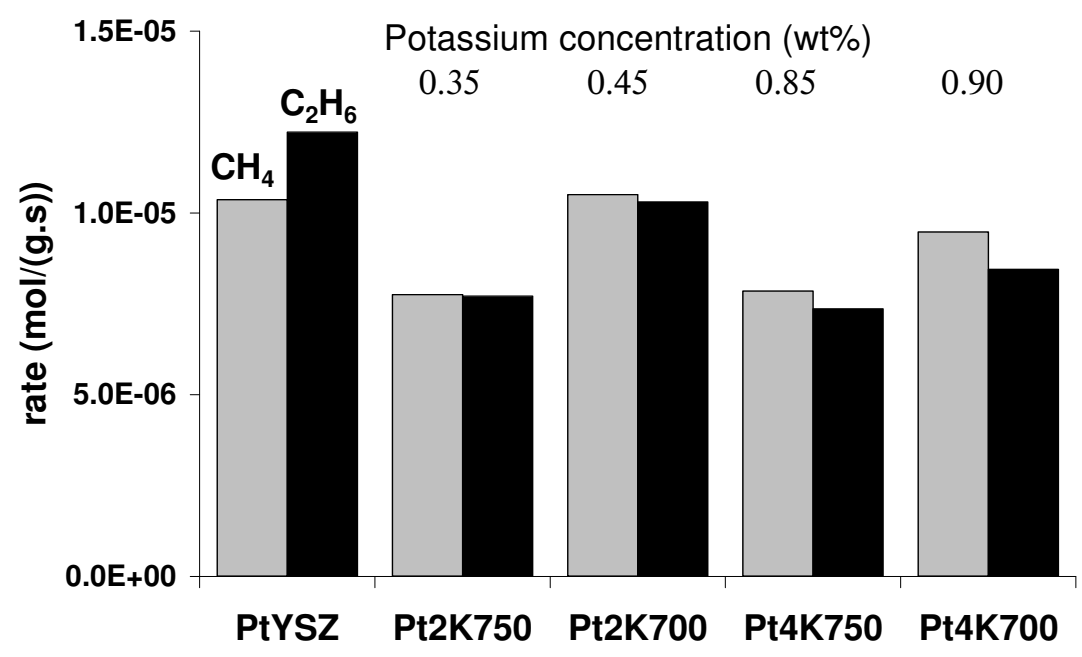

Figure 3.2: Overview of steam reforming reaction rates after stabilization in a mixture of methane (5vol.\%) and ethane (2.2vol.\%) for the catalysts shown in Figure 3.1

Figure 3.2 presents a comparison of the maximal reaction rates for both methane and ethane for all catalysts. The unmodified PtYSZ showed the highest activity expressed in mol per gram of catalyst per second. Both initial and final potassium content increases from left to right in Figure 3.2, and there is no obvious relation between the potassium content and the maximum rates. The maximum activity for the samples calcined at $700^{\circ} \mathrm{C}(\mathrm{Pt} 4 \mathrm{~K} 700$ and $\mathrm{Pt} 2 \mathrm{~K} 700)$ is 1.25 times higher than for the equivalent catalysts calcined at $750^{\circ} \mathrm{C}(\mathrm{Pt} 4 \mathrm{~K} 750$ and $\mathrm{Pt} 2 \mathrm{~K} 750)$. Interestingly, the relative reactivity of methane and ethane in the mixture is clearly influenced by the presence of potassium. As shown in Table 3.2, increasing the $\mathrm{K}$ concentration causes the ratio of reaction rates between methane and ethane (rate $\mathrm{CH}_{4} /$ rate $\mathrm{C}_{2} \mathrm{H}_{6}$ ) to increase. 
Table 3.2: Ratio of methane and ethane reaction rate on unmodified PtYSZ and potassium modified catalysts $\left(5\right.$ vol. \% $\mathrm{CH}_{4} / 2.2$ vol. \% $\left.\mathrm{C}_{2} \mathrm{H}_{6}\right)$.

\begin{tabular}{|c|c|}
\hline Catalyst & Ratio $\mathrm{CH}_{4} / \mathrm{C}_{2} \mathrm{H}_{6}$ converted \\
\hline PtYSZ & $0.81 \pm 0.01$ \\
\hline Pt2KYSZ750 & $1.00 \pm 0.02$ \\
\hline Pt2KYSZ700 & $1.02 \pm 0.02$ \\
\hline Pt4KYSZ750 & $1.07 \pm 0.02$ \\
\hline Pt4KYSZ700 & $1.12 \pm 0.02$ \\
\hline
\end{tabular}

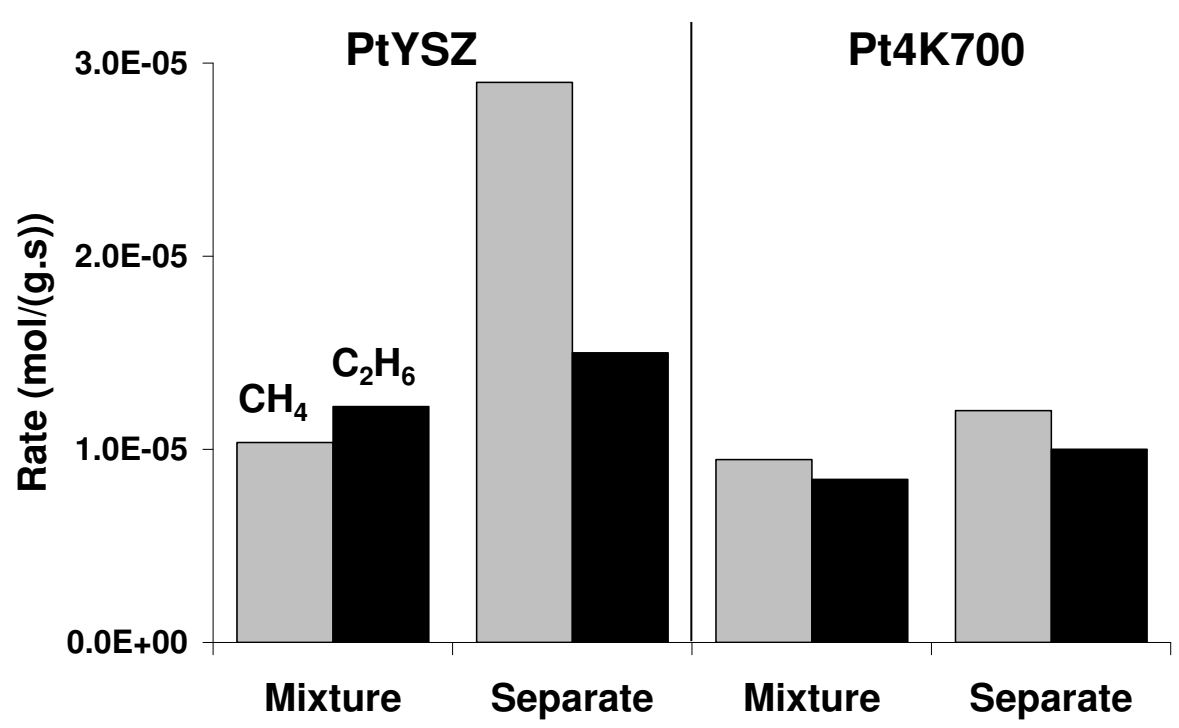

Figure 3.3: Reaction rates of methane (5vol.\%) and ethane (2.2vol.\%), when fed as a mixture versus fed separately on PtYSZ (left) and Pt4K700 (right).

In Figure 3.3, the reaction rates obtained with methane/ethane mixtures are compared with the reaction rates measured when feeding separately $5 \mathrm{vol} \%$ of methane or 2.2vol.\% ethane for PtYSZ and Pt4K700. These experiments were performed with fully activated Pt4K700 and with fresh PtYSZ, respectively. The results clearly show that, operating with methane only, PtYSZ is almost 3 times as active for methane reforming as compared to feeding a mixture of methane and ethane. Interestingly on Pt4K700, the same effect is much smaller (factor 1.25). Moreover, while using the mixture both catalysts show similar methane and ethane conversion rates, Pt4K700 is about 2.5 times less active than PtYSZ for methane reforming when methane only is fed. For ethane the differences between operating with a mixture and separate feed are 
smaller: the reaction rate of ethane fed separately is 1.23 times higher for PtYSZ and 1.18 times higher for Pt4K700 compared to the ethane conversion rate in the mixture.

Since the observed reaction rates of methane and ethane strongly depend on feed composition, a more detailed comparison of the effect of the composition of the mixtures on the performance of both catalysts is presented below.

Both catalysts were tested with varying ethane concentrations ( $0.74 \mathrm{vol} . \%$ to $2.2 \mathrm{vol} . \%)$ while keeping the methane concentration constant $(7.7 \mathrm{vol} . \%)$. The choice for these concentrations was based on keeping the carbon to $\mathrm{H}_{2} \mathrm{O}$ ratio as close as possible to 1 . In fact, it varies from 1.2 to 1.0 . Pt4K700 was tested after activation and stabilization. To avoid influences of catalyst deactivation on PtYSZ, a water/Ar mixture was fed at reaction conditions for 15 minutes between measurements. This treatment was sufficient to fully reactivate the catalysts. Data were measured in random order and initial activities are reported for PtYSZ. The reaction rates and conversion for methane and ethane at $700^{\circ} \mathrm{C}$ are shown in Figure 3.5A (PtYSZ) and Figure 3.5B (Pt4K700).

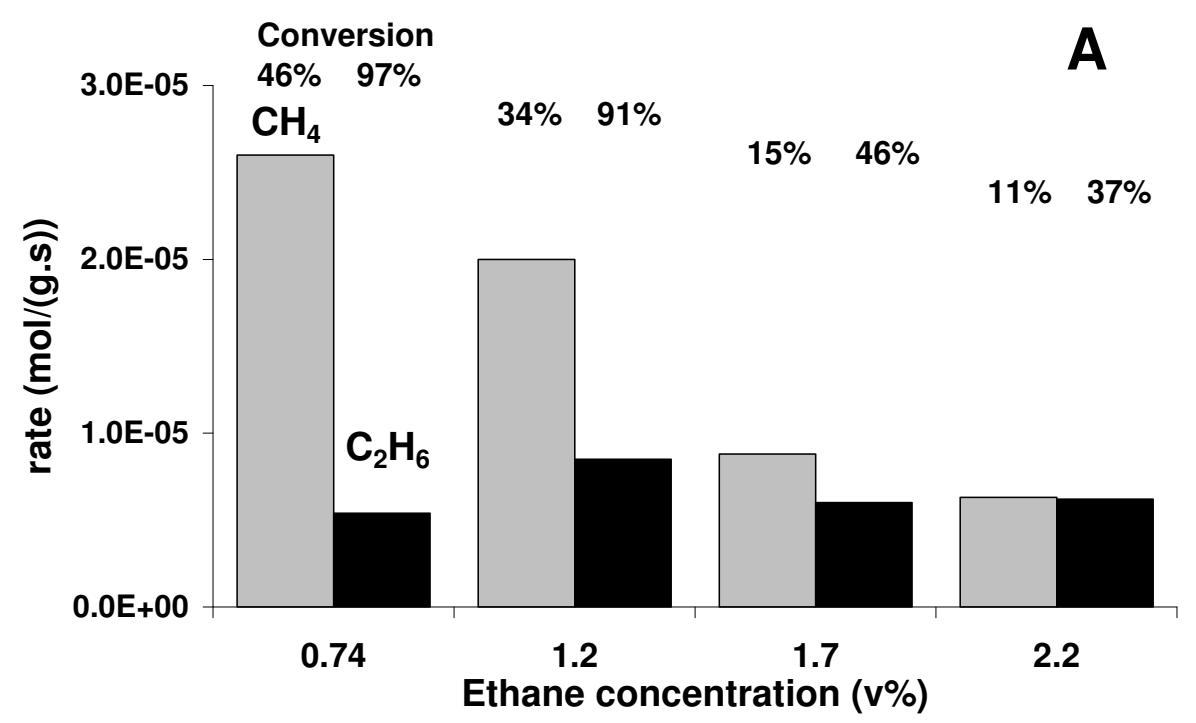

Figure 3.4A: Reaction rates and conversions for methane and ethane reforming on PtYSZ (A) in mixtures with constant methane concentration $(7.7 \mathrm{vol} . \%)$, varying the ethane concentration (0.74-2.2vol.\%) 


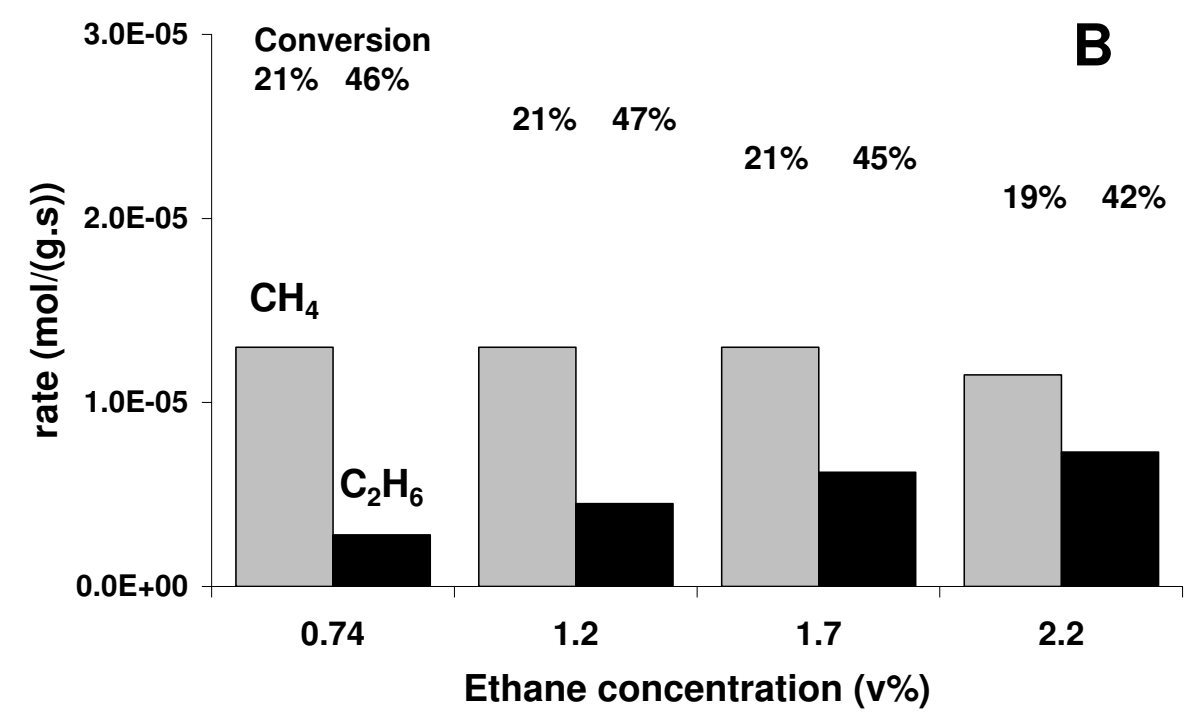

Figure 3.5B: Reaction rates and conversions for methane and ethane reforming on Pt4K700 (B) in mixtures with constant methane concentration $(\mathbf{7 . 7 v o l} \%)$, varying the ethane concentration (0.74- 2.2vol.\%)

For PtYSZ a high reaction rate for methane was observed at low ethane concentration (left side Figure 3.5A). The methane reaction rate reduced dramatically by a factor 4 when the ethane concentration was increased from 0.74 to $2.2 \mathrm{vol} . \%$. The methane conversion decreased from $46 \%$ to $11 \%$ in this range. No trend was observed in the ethane reaction rate and conversion. At low concentrations (0.74 and 1.2vol.\%), ethane conversion was above 90\%. Ethane conversion decreased to around $37 \%$, when increasing the ethane concentration to $2.2 \mathrm{vol} . \%$. Further, the total number of hydrocarbon molecules converted per time over PtYSZ decreases with increasing carbon concentration in the feed.

On Pt4K700, the methane reaction rate was almost unaffected by increasing ethane concentration (Figure 3.5B), in contrast to PtYSZ. Only at the highest ethane concentration $(2.2 \mathrm{vol} . \%)$, methane reaction rate decreased by $10 \%$. This almost constant reaction rate of methane also induces a constant conversion of $21 \%$ for the three lower concentrations of ethane, decreasing slightly to $19 \%$ when increasing ethane concentration to $2.2 \mathrm{vol} . \%$. The ethane reaction rate showed a linear increase with increasing concentration. Ethane conversion was constant around 45\%. This indicates apparent first order behaviour of ethane reforming when fed together with 
methane. Finally, in contrast to PtYSZ, the total number of molecules converted per time increased with increasing carbon concentration on Pt4K700.

The reaction rate of methane was higher than that of ethane on Pt4K700 for all conditions used in this series of experiments. Thus, Pt4K700 converts more methane than ethane when methane is present in excess. To investigate the behaviour of this catalyst with similar methane and ethane concentrations, methane concentrations were varied between 2.4 to $7.7 \mathrm{vol} \%$, keeping the ethane concentration constant at 2.2vol.\%. The results are shown in Figure 3.6. Other experiments (not shown here) demonstrated that changing the water to carbon ratio in this range did not influence reaction rates found on $\mathrm{Pt} 4 \mathrm{~K} 700$.

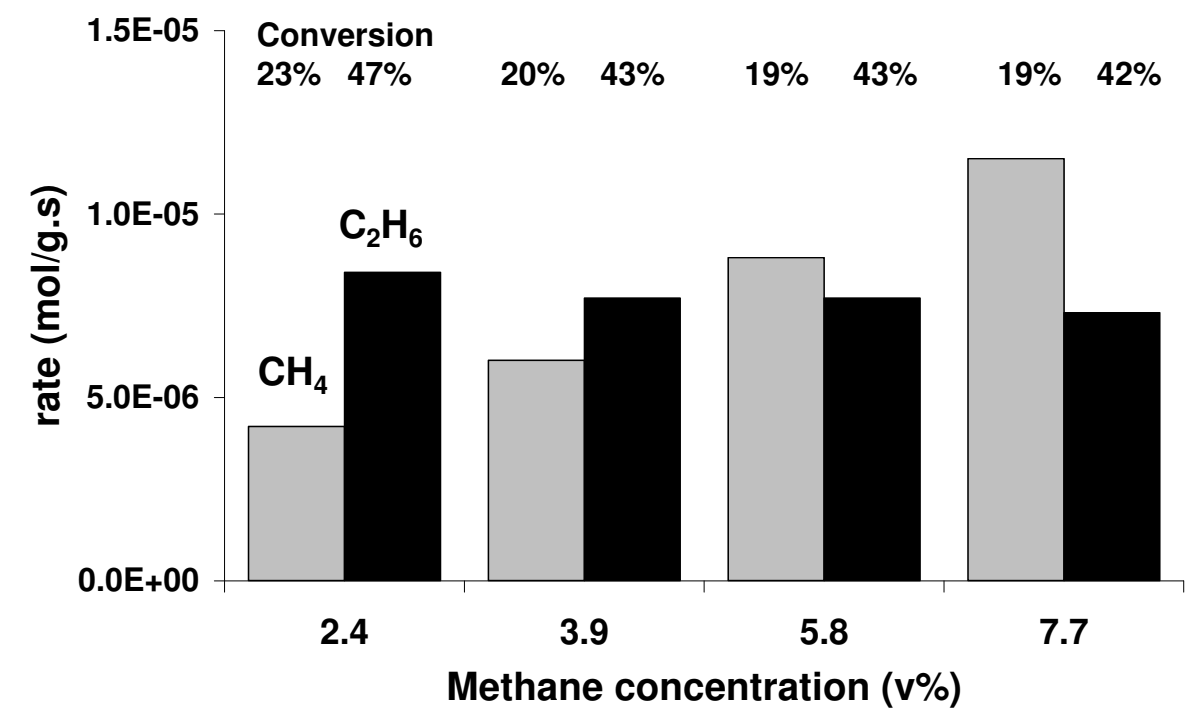

Figure 3.6: Reaction rates and conversion for methane and ethane on Pt4K700 in mixtures with constant ethane concentration ( $2.2 \mathrm{vol} . \%)$ and variable methane concentration $(2.4-7.7 \mathrm{vol} . \%)$

In the experiments shown in Figure 3.6, clearly the ethane reaction rate was hardly affected when increasing the methane concentration. Thus, the conversion of ethane was almost constant, only decreasing from $46 \%$ to $42 \%$ with increasing methane concentration from 2.4 to $7.7 \mathrm{vol} . \%$. Further, the reaction rate of methane increased linearly with methane concentration, indicating apparent first order in methane. Again, the total number of molecules converted increased with increasing hydrocarbon concentration. 
Figure 3.7 shows the ratio of methane to ethane rates of conversion for PtYSZ and Pt4K700 as a function of the inlet $\mathrm{CH}_{4} / \mathrm{C}_{2} \mathrm{H}_{6}$ ratio from experiments, varying both $\mathrm{CH}_{4}$ and $\mathrm{C}_{2} \mathrm{H}_{6}$ concentrations. Only at very high methane/ethane inlet ratio (10.4), PtYSZ converts more methane than Pt4K700. In agreement, reforming of methane only (Figure 3.3) shows a higher reaction rate on the unmodified catalyst. For all other conditions, Pt4K700 showed an improved methane to ethane ratio.

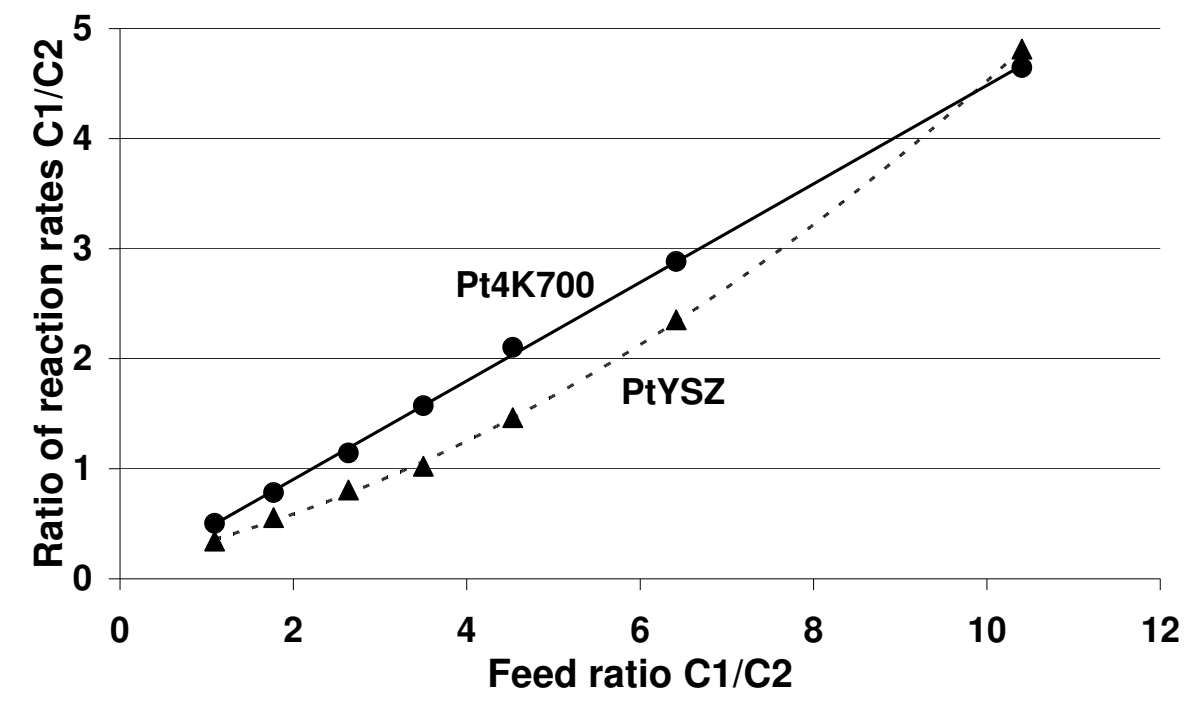

Figure 3.7: Ratio of reaction rates of methane/ethane as a function of methane/ethane feed ratio in steam reforming on PtYSZ and Pt4K700 


\subsection{Discussion}

The addition of potassium to Pt supported on yttrium stabilised zirconia (YSZ) showed several effects on the catalytic performance in steam reforming of ethane and methane: 1. activation with TOS was observed, 2. maximum catalyst activity decreased, 3. the ratio between methane and ethane reaction rates changed and 4 . the competition between hydrocarbons decreased. Each of these phenomena will be discussed below.

\subsubsection{Activation behaviour of potassium modified catalysts}

Clearly, the activity of the potassium modified catalysts increased with TOS, (Figure 3.1B to Figure 3.1E), while the unmodified catalyst deactivated during the whole experiment (Figure 3.1A). The time needed for activation is determined by the initial potassium content: with more potassium added, the time needed to reach steady state increased. Catalysts calcined at $700^{\circ} \mathrm{C}$ had a higher initial potassium content than the catalysts calcined at $750^{\circ} \mathrm{C}$ (Table 3.1) and consequently showed a longer activation period, ranging from 200 to 800 minutes. It was also found that potassium was removed during the activation process (Table 3.1). This can be explained by evaporation of $\mathrm{K}$ via the formation of volatile hydroxides at temperatures around $700^{\circ} \mathrm{C}$ [17]. It should be noted that after the activation period no further potassium evaporation between 20 and 85 hours of reaction (Table 3.1) was detected for Pt4K700. Although the concentration of K stabilized, very slow removal of K cannot be excluded, as the maximal time-on-stream was limited to 85 hours in this study.

It was noticed that the unmodified PtYSZ deactivated with TOS, whereas potassium addition led to a stable performance after an initial activation period (Figure 3.1A to Figure 3.1E). It is well known that potassium promotes the activation of water [18, 19], which helps to remove hydrocarbon fragments from the surface. This could explain stable performance over a longer period of time, in agreement with the observation that PtYSZ could be easily regenerated in a stream of $12 \mathrm{vol} . \%$ water in Argon for 15 minutes at $700^{\circ} \mathrm{C}$.

\subsubsection{Activity of the catalysts}

Figure 3.3 clearly shows a lower activity for the stabilized potassium modified catalysts during steam reforming of the single hydrocarbons ethane and methane as 
compared to the unmodified PtYSZ catalyst. Potassium addition decreased the activity for methane decreased by $60 \%$, while for ethane the effect was somewhat less, about $33 \%$. In ethane/methane mixtures, the effect of added potassium is only visible at relative low ethane/methane ratios (Figure 3.5). The decreased activity is in agreement with results of Trimm and Rostrup-Nielsen [13, 14], who reported lower reactivity by more than one order of magnitude when adding potassium to $\mathrm{Ni}$ catalysts on several supports.

\subsubsection{Influence of potassium on reaction ratio of $\mathrm{CH}_{4} / \mathrm{C}_{2} \mathrm{H}_{6}$}

The relative reactivity of methane and ethane is also influenced by potassium as shown in Figure 3.1A to Figure 3.1E and Table 3.2. It appears that the unmodified catalyst converted more ethane than methane (Figure 3.1A). The reaction rate of methane was close to the ethane reaction rate for low potassium amounts (Figure 3.1B and Figure 3.1C). For higher potassium amounts, the methane reaction rate is even higher than the ethane reaction rate (Figure 3.1D and Figure 3.1E). Interestingly, for all catalysts, a constant ratio of reaction rates of methane and ethane was found during the experiments. In addition, Figure 3.7 shows that the actual ratio of methane/ethane rates of conversion depends on the inlet methane/ethane ratio. Pt4K700 converts more methane than PtYSZ, when the methane/ethane inlet ratio is below 10. However, PtYSZ is more active for methane than Pt4K700 in case of high excess of methane. This agrees with Figure 3.3 showing higher methane reaction rates on PtYSZ when no ethane is present.

In Figure 3.8, the ratio of methane and ethane reaction rates from Table 3.2 is related to the potassium content for all catalysts in the activated state (Table 3.1). A linear relationship was found between the ratio of reaction rates of methane and ethane and the potassium content in the activated state. Moreover, the additional potassium present in the fresh catalyst, which evaporates during activation, does not influence the ratio between methane and ethane reaction rate, since this was constant during activation (Figure 3.1B to Figure 3.1E). 


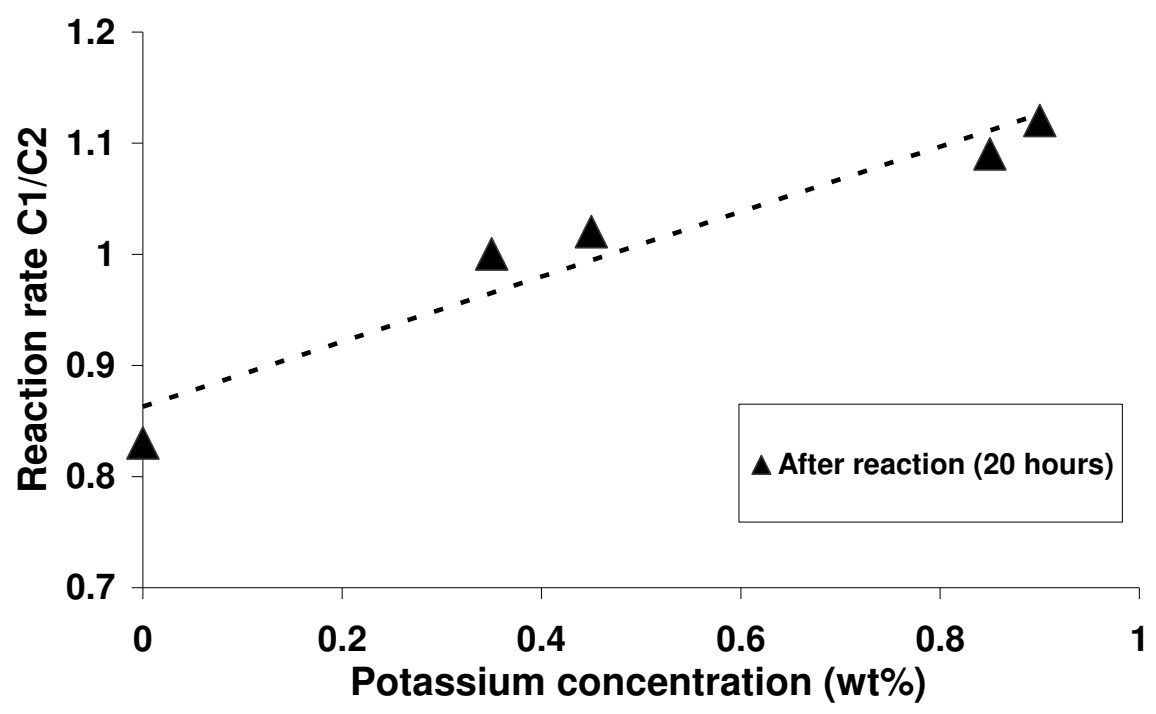

Figure 3.8: Ratio of methane reaction rate and ethane reaction rate, related to PtYSZ and potassium modified catalysts in activated state

\subsubsection{Competition effects in hydrocarbon mixtures}

Finally, addition of ethane had a drastic effect on the conversion of methane on PtYSZ (Figure 3.3, Figure 3.5A). Ethane and methane obviously compete for the same reactive Pt-sites and limit each others conversion: conversions of both components decreased. Consequently, high conversion of methane on Pt/YSZ is only possible in the absence of ethane and at low ethane concentrations (Figure 3.3, Figure $3.5 \mathrm{~A})$.

On Pt4K700, this behaviour was not observed. Methane and ethane seem to react independently and both showed first order behaviour when mixed (Figure 3.5B, Figure 3.6). Within the applied concentration range, increasing the concentration of one component hardly affected the other component's reaction rate. Further, Figure 3.3 shows that the reaction rates of methane or ethane separately on an activated potassium catalyst are similar to the rates in the mixture.

The initial aim of this study was to find a catalyst in which methane is effectively converted while the steam reforming of ethane is limited. The present results show that indeed the ratio of methane reaction rate to ethane reaction rate is improved when adding potassium to PtYSZ, via suppression of competition effects between the two reactants. As a result methane conversion is boosted compared to ethane. 
Unfortunately, ethane conversion is hardly suppressed by the addition of potassium. A catalyst that clearly suppresses ethane conversion would be needed to make the overall concept of oxidative coupling combined with steam reforming applicable.

Nevertheless, the results show an unexpected effect of potassium on the catalytic behaviour of supported platinum catalysts. The most important conclusion in this respect is that potassium is able to prevent competitive behaviour between methane and ethane. The origin of this intriguing effect is currently investigated by characterization with FT-IR spectroscopy and will be the scope of a future publication.

\subsection{Conclusion}

The addition of potassium has a significant effect on the steam reforming of methane and ethane. Similar to results on $\mathrm{Ni}$ catalysts reported in literature, potassium improves catalyst stability at the expense of decreasing catalyst activity. The potassium modified catalysts activated with TOS which was attributed to partial potassium evaporation during steam reforming. Importantly, this study shows that the steam reforming rates of methane and ethane are affected quite differently by the presence of potassium. Potassium prevents inhibition of methane steam reforming by the presence of ethane. The reaction rate ratio in methane/ethane mixtures is changed from preferential ethane reforming on PtYSZ towards preferential methane conversion as a result of addition of potassium. 


\subsection{References}

[1] P.O. Graf, B.L. Mojet, J.G. van Ommen, L. Lefferts, Applied Catalysis A: General 332 (2007) 310-317.

[2] D.L. Trimm, Catalysis Today 37 (1997) 233.

[3] J.H. Bitter, W. Hally, K. Seshan, J.G. van Ommen, J.A. Lercher, Catalysis Today 29 (1996) 349-353.

[4] J.H. Bitter, K. Seshan, J.A. Lercher, Journal of Catalysis 171 (1997) 279.

[5] M.E.S. Hegarty, A.M. O'Connor, J.R.H. Ross, Catalysis Today 42 (1998) 225.

[6] A.M. O'Connor, J.R.H. Ross, Catalysis Today 46 (1998) 203.

[7] J.H. Sinfelt, Journal of Catalysis 27 (1972) 468-\&.

[8] J.H. Sinfelt, D.J.C. Yates, Journal of Catalysis 10 (1968) 362-\&.

[9] J.H. Sinfelt, D.J.C. Yates, Journal of Catalysis 8 (1967) 82-\&.

[10] J. Sehested, Catalysis Today 111 (2006) 103-110.

[11] J.W. Snoeck, G.F. Froment, M. Fowles, Industrial and Engineering Chemistry Research 41 (2002) 3548-3556.

[12] J. Juan-Juan, M.C. Roman-Martinez, M.J. Illan-Gomez, Applied Catalysis A: General 301 (2006) 9-15.

[13] D.L. Trimm, Catalysis Today 49 (1999) 3.

[14] J.R. Rostrup-Nielsen, Journal of Catalysis 31 (1973) 173.

[15] M. Matsumura, C. Hirai, Journal of Chemical Engineering of Japan 31 (1998) 734.

[16] M. Ferrandon, J. Mawdsley, T. Krause, Applied Catalysis A: General In Press, Corrected Proof.

[17] R.J. Berger, E.B.M. Doesburg, J.G. van Ommen, Journal of the Electrochemical Society 143 (1996) 3186-3191.

[18] F. Frusteri, S. Freni, V. Chiodo, L. Spadaro, O. Di Blasi, G. Bonura, S. Cavallaro, Applied Catalysis A: General 270 (2004) 1-7.

[19] D. Sutton, B. Kelleher, J.R.H. Ross, Fuel Processing Technology 73 (2001) 155173. 



\title{
Chapter 4
}

\section{The effect of potassium addition to Pt supported on YSZ on steam reforming of mixtures of methane and ethane}

\begin{abstract}
The influence of potassium addition on Pt supported on yttrium-stabilized zirconia (YSZ) was studied with FT-IR CO adsorption and CO FT-IR TPD, in order to understand the effect of potassium on the performance of the catalyst in reforming of mixtures of methane and ethane. Potassium modification of PtYSZ strongly influenced the conversion and rate determining steps in methane and ethane in steam reforming. Water activation is the rate determining step on PtYSZ, resulting in high surface coverage of hydrocarbon fragments during steam reforming of mixtures of methane and ethane. This led to blocking of active sites by ethane fragments and consequently low conversion of methane. If potassium is added to the catalyst, hydrocarbon activation on $\mathrm{Pt}$ is rate determining, resulting in low surface coverage of methane and ethane. As a result, competition effects of methane and ethane diminished on potassium modified PtYSZ, enabling simultaneous conversion of methane and ethane. The weakening of the interaction of the hydrocarbons with the $\mathrm{Pt}$ surface as a result of potassium addition is supported by the fact that the interaction with CO is weakened, as observed with FT-IR TPD.
\end{abstract}




\subsection{Introduction}

Natural gas, mainly consisting of methane, is available in large quantities and is becoming one of the major resources for energy and chemicals. A new concept for utilization of methane has been proposed by us, as discussed in detail in earlier work $[1,2]$. Shortly, the intention is to combine oxidative coupling and inevitable combustion with reforming reactions of methane (equations (1) to (4)) in one multifunctional auto thermal reactor. This should lead to production of ethylene and synthesis gas in one auto thermal process, in which the energy released in reactions (1) and (2) is used to reform methane through reactions (3) and (4).

$$
\begin{array}{lll}
\mathrm{CH}_{4}+1 / 2 \mathrm{O}_{2} \rightarrow 1 / 2 \mathrm{C}_{2} \mathrm{H}_{4}+\mathrm{H}_{2} \mathrm{O} & \Delta \mathrm{H}^{\circ}{ }_{298} & =-140 \mathrm{~kJ} / \mathrm{mol} \\
\mathrm{CH}_{4}+2 \mathrm{O}_{2} \rightarrow \mathrm{CO}_{2}+2 \mathrm{H}_{2} \mathrm{O} & \Delta \mathrm{H}^{\circ}{ }_{298} & =-801 \mathrm{~kJ} / \mathrm{mol} \\
\mathrm{CH}_{4}+\mathrm{H}_{2} \mathrm{O} \rightarrow 3 \mathrm{H}_{2}+\mathrm{CO} & \Delta \mathrm{H}^{\circ}{ }_{298}=206 \mathrm{~kJ} / \mathrm{mol} \\
\mathrm{CH}_{4}+\mathrm{CO}_{2} \rightarrow 2 \mathrm{H}_{2}+2 \mathrm{CO} & \Delta \mathrm{H}^{\circ}{ }_{298}=247 \mathrm{~kJ} / \mathrm{mol}
\end{array}
$$

For the complete process, two catalysts are needed, one for oxidative coupling and one for the reforming reaction. This paper reports about the steam reforming step (3) of the mixture produced in the oxidative coupling, containing methane, ethane and ethylene. All these hydrocarbons are reactive in steam-reforming [3]. The main challenge in this project is to prevent or limit the steam reforming of ethane and ethylene, while methane should be effectively converted.

Pt supported on zirconia proved to be a stable catalyst in steam and dry reforming of methane [4-7]. In earlier research [2], Pt supported on yttrium stabilized zirconia (YSZ) was found to be the most suitable metal catalyst for steam reforming of single reactants. However, in mixtures of hydrocarbons methane conversion was suppressed by presence of ethane or ethylene [1]. It also was demonstrated that the presence of potassium on PtYSZ (Pt4K700) prevents competition between methane and ethane during steam reforming and relatively more methane can be converted [1]. In accordance with literature [8-12], potassium modified catalysts initially showed low activity. Potassium modified catalysts activated with TOS (Time On Stream), which 
was attributed to partial evaporation of potassium during steam reforming. In the present paper, the characterization of the catalysts is discussed.

An easily accessible technique to study the surface properties of supported platinum catalysts is the adsorption of $\mathrm{CO}$ [13-15] (and references therein). The addition of potassium to noble metal catalysts is known to influence the electronic structure of the surface atoms via modification of the metal particle potential [16-20]. In turn, the electronic properties of the metal particle have been related to their catalytic properties in hydrogenolysis, hydrogenation and oxidation reactions [13-15, 21]. Usually characterization studies are performed on small metal particles (few nanometers). However, in the present study, the relevant temperature window for steam reforming is between $700^{\circ} \mathrm{C}$ and $800^{\circ} \mathrm{C}$, because of the integrated operation of reforming and oxidative coupling. This means that $\mathrm{Pt}$ particles are relatively large (10$100 \mathrm{~nm}$ ); with the lower number of surface sites characterization becomes a challenging issue.

In this paper, reactivity of methane and ethane in steam reforming on PtYSZ and potassium modified PtYSZ is investigated and the catalysts are characterized with FTIR spectroscopy. TPD of CO on unmodified PtYSZ and potassium modified PtYSZ is used to estimate trends in the adsorption strength of methane and ethane. Also reaction kinetics of steam reforming of mixtures of methane and ethane on PtYSZ and Pt4K700 are investigated and related to the characterization data, resulting in an explanation why potassium is preventing reactant competition between methane and ethane. 


\subsection{Experimental}

Yttrium stabilized zirconia (YSZ), obtained from TOSOH (TZ-8Y) was used as support and was modified with $4 \mathrm{wt}$.\% potassium. About 15g of YSZ was impregnated with $15 \mathrm{ml}$ of an aqueous $\mathrm{K}_{2} \mathrm{CO}_{3}$ solution, containing $1 \mathrm{~g}$ of $\mathrm{K}_{2} \mathrm{CO}_{3}$ and calcined in synthetic air (30ml/min) for 4 hours at $600^{\circ} \mathrm{C}$ (temperature ramp $5^{\circ} \mathrm{C} \mathrm{min}^{-1}$ ).

Subsequently, $1 \mathrm{wt} \%$ of $\mathrm{Pt}$ was impregnated on $10 \mathrm{~g}$ of support with a $\mathrm{H}_{2} \mathrm{PtCl}_{6}$ (Alfa Aesar) solution containing 0.01g Pt per ml aqueous solution. PtYSZ was calcined at $750^{\circ} \mathrm{C}$. The potassium modified samples were calcined at two different temperatures, $700^{\circ} \mathrm{C}$ and $750^{\circ} \mathrm{C}$ respectively. Catalysts were calcined in synthetic air $(30 \mathrm{ml} / \mathrm{min})$ during $15 \mathrm{~h}\left(\operatorname{ramp} 5^{\circ} \mathrm{C} \min ^{-1}\right.$ ). Next to PtYSZ, two potassium modified catalysts were used, designated by initial potassium content (wt.\%) and calcination temperature: Pt4K700 and Pt4K750.

Activity tests were carried out in a micro reactor flow setup. The reactor consisted of a quartz tube with inner and outer diameter of respectively 4 and $6 \mathrm{~mm}$. Catalyst particles with a diameter between 0.3 and $0.6 \mathrm{~mm}$ were used, resulting in a pressure drop around $0.1 \mathrm{bar}$, when $200 \mathrm{mg}$ of catalyst was loaded between quartz wool plugs. The samples were heated to $500^{\circ} \mathrm{C}$ in argon and reduced in $2.5 \mathrm{vol} . \% \mathrm{H}_{2}$ (Indugas 5.0) / Ar for $1 \mathrm{~h}$ (flow rate: $200 \mathrm{ml} / \mathrm{min}$ ) before measuring the catalytic performance. No significant activity for steam reforming of methane and ethane was found for the support material $\mathrm{YSZ}$ at $700^{\circ} \mathrm{C}$. Also the occurrence of gas phase reactions could be excluded based on experiments with quartz particles of 0.3 to $0.6 \mathrm{~mm}$.

Methane (Hoekloos 4.5) and ethane (Indugas 4.0) were mixed with argon (Hoekloos 5.0) to a total flow rate of $200 \mathrm{ml} \cdot \mathrm{min}^{-1}$. Measurements were performed at $700^{\circ} \mathrm{C}$. Water was added to the gas mixtures with a Bronkhorst controlled evaporator mixer (CEM) in combination with a Liquiflow controller. To ensure constant space velocity, Ar flow was adjusted when water concentrations were changed. A 15 minute treatment of 11 vol.\% water in Argon was applied between the separate experiments on PtYSZ to regenerate the catalyst. The product and reactant gas composition was analyzed with a Varian 3800 Gas Chromatograph equipped with two columns (Molsieve 5A and PoraPlotQ) and two TCD detectors. Water was analyzed in the PoraPlotQ column; the Molsieve column was protected against water by a PoraPlotQ 
pre-column and a backflush system. Argon was used as internal standard to correct for volume changes during reaction.

Elemental composition of the catalysts was determined with XRF on a Philips PW $1480 \mathrm{X}$-ray spectrometer. The structure of the catalysts was studied with X-ray diffraction with a Philips PW1830 diffractometer using $\mathrm{Cu} \mathrm{K \alpha}$ radiation, $\lambda=0.1544 \mathrm{~nm}$. XRD was performed in reflection geometry in the $2 \theta$ range between $20^{\circ}$ and $70^{\circ}$. Average Pt particle size was estimated using the Scherrer equation [22]. Before XRD analysis of spent catalysts, samples were cooled to room temperature in He and exposed to air.

The transmission FT-IR CO adsorption measurements were carried out on a Bruker Vector 22 with MCT detector. A self supporting pellet was pressed, using $15 \mathrm{mg}$ of the catalyst. Before measurements the samples were reduced in 5 vol. $\% \mathrm{H}_{2}$ at $400^{\circ} \mathrm{C}$ and subsequently cooled to room temperature in He. CO (Linde Gas 4.7) was absorbed at room temperature and subsequently desorbed with a heating rate of $2{ }^{\circ} \mathrm{C} / \mathrm{min}$. 


\subsection{Results}

\subsubsection{Catalyst characterization}

It was reported in an earlier paper [1] that potassium modified catalysts activated with time on stream during reforming of methane and ethane mixtures. The reaction rates initially increased and stabilized after 200 to 800 minutes of reforming of the methane and ethane mixture (a longer activation period was required with higher initial potassium content of the catalysts). The initial period of increasing activity will be referred to as "activation" in this paper. Potassium modified catalysts tested or characterized after activation are indicated with "act". Catalysts indicated with "fresh" were tested or characterized directly after calcination. The unmodified PtYSZ was tested and characterized in fresh state. PtYSZ showed initially the highest activity and slowly deactivated as a result of carbon formation [1]. After measuring the performance of PtYSZ for one specific set of experimental conditions, the catalyst was regenerated following the procedure described in [1], before the next experiment was performed.

Table 4.1 shows the Pt particle size for all catalysts, measured by XRD-Line Broadening. All catalysts show Pt particles between 30 and $40 \mathrm{~nm}$. Calcination of potassium modified PtYSZ at $700^{\circ} \mathrm{C}$ results in smaller Pt particles than calcination at $750^{\circ} \mathrm{C}$ (Table 4.1). It is also shown in Table 4.1 that $\mathrm{Pt}$ particle size remained unchanged during activation for both Pt4K700 and Pt4K750.

Potassium contents of fresh and used catalysts, as measured with XRF before and after steam reforming reaction, are given in Table 4.1. The potassium samples were initially impregnated with $4 \mathrm{wt} . \%$ of potassium, and it was observed that calcination temperature influences the remaining potassium content. Calcination at $700^{\circ} \mathrm{C}$ leads to $2.05 \mathrm{wt} . \%$ of potassium, Calcination at $750^{\circ} \mathrm{C}$ results in only $1.6 \mathrm{wt} . \%$ remaining. About $50 \%$ of the potassium is lost on Pt4K700 and Pt4K750 during activation. 
Table 4.1: Pt particle size determined by XRD and potassium content determined by XRF for PtYSZ, Pt4K700act, Pt4K700fresh, Pt4K700act and Pt4K750initial

\begin{tabular}{|l|c|c|c|}
\hline \multicolumn{1}{|c|}{ Catalyst } & Pt content wt.\% & $\begin{array}{c}\text { Average Pt particle } \\
\text { size }\end{array}$ & Potassium content wt.\% \\
\hline PtYSZ* & $1.04 \pm 0.03$ & $32 \pm 1 \mathrm{~nm}$ & - \\
\hline Pt4K700act & $1.03 \pm 0.03$ & $30 \pm 2 \mathrm{~nm}$ & $0.90 \pm 0.03$ \\
\hline Pt4K700fresh & $1.03 \pm 0.03$ & $31 \pm 3 \mathrm{~nm}$ & $2.05 \pm 0.06$ \\
\hline Pt4K750act & $1.01 \pm 0.03$ & $38 \pm 3 \mathrm{~nm}$ & $0.85 \pm 0.03$ \\
\hline Pt4K750fresh & $1.01 \pm 0.03$ & $38 \pm 3 \mathrm{~nm}$ & $1.60 \pm 0.05$ \\
\hline
\end{tabular}

$*$ calcined at $750^{\circ} \mathrm{C}$

The FT-IR spectra of adsorbed CO to characterize the accessible Pt surface are shown in Figure 4.1. Results of potassium modified samples are shown here for Pt4K700. For all samples $15 \mathrm{mg}$ of catalyst was used.

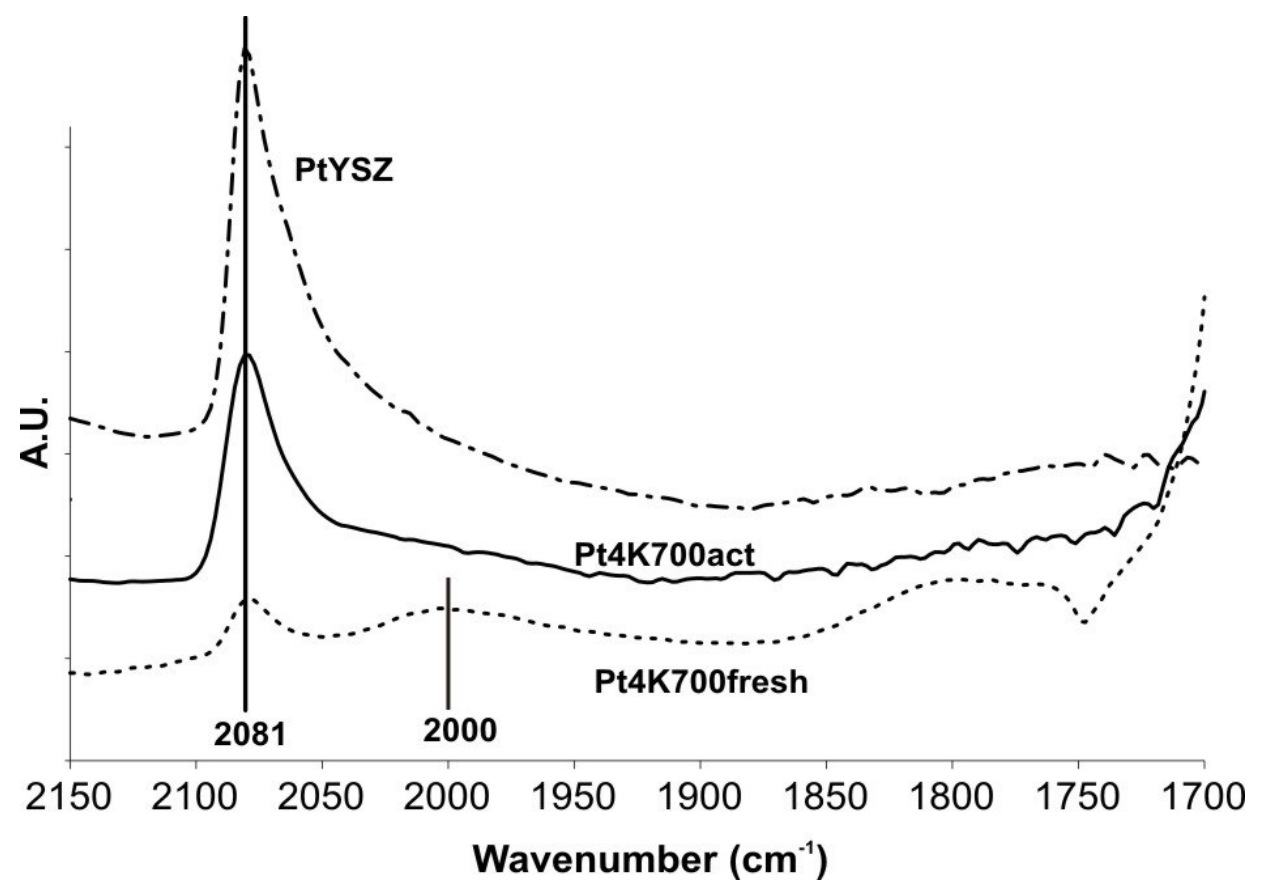

Figure 4.1 FT-IR CO adsorption spectra at room temperature for PtYSZ, Pt4K700fresh and Pt4K700act

PtYSZ, Pt4K700act and Pt4K700fresh all showed a band at $2081 \mathrm{~cm}^{-1}$, attributed to CO linearly adsorbed on Pt [23]. This band had a low intensity on Pt4K700fresh. Further, a broad band around $2000 \mathrm{~cm}^{-1}$ was found on Pt4K700fresh, which was assigned previously to a direct ion-dipole interaction between $\mathrm{K}^{+}$and linear $\mathrm{CO}[24,25]$. Also, a broad band around $1800 \mathrm{~cm}^{-1}$ was found on Pt4K700fresh, ascribed to CO coordinated in bridged position. Pt4K700act shows a larger peak at $2081 \mathrm{~cm}^{-1}$ 
compared to Pt4K700fresh, while the bands at $2000 \mathrm{~cm}^{-1}$ and $1800 \mathrm{~cm}^{-1}$ were absent. The total integrated intensities for the different peaks are given in Table 4.2. It should be noted that the area of the peak around $1800 \mathrm{~cm}^{-1}$ on Pt4K700 fresh is less accurate, as the large peak around $1700 \mathrm{~cm}^{-1}$ might partially contribute to its intensity. Clearly, on Pt4K700act, the peak at $2081 \mathrm{~cm}^{-1}$ increased by a factor 5 compared to Pt4K700fresh. The total peak area of Pt4K700act is still significantly smaller than of PtYSZ.

Table 4.2: Peak area between $2100 \mathrm{~cm}^{-1}$ and $1900 \mathrm{~cm}^{-1}$ of FT-IR CO spectra of PtYSZ, Pt4K700act and Pt4K700fresh as shown in Figure 4.1 (Integration interval between brackets).

\begin{tabular}{|l|c|c|c|}
\hline Catalyst & Band 2081 cm & $\begin{array}{c}\text { Band 2000cm } \\
\mathbf{( 2 0 3 0 - 1 9 5 0 )}\end{array}$ & $\begin{array}{c}\text { Band 1800cm }^{-1} \\
\mathbf{( 1 8 8 0 - 1 7 5 0})\end{array}$ \\
\hline PtYSZ & $\mathbf{0 . 4 9}(2100-2000)$ & - & - \\
\hline Pt4K700act & $\mathbf{0 . 3 2}(2100-2000)$ & - & - \\
\hline Pt4K700fresh & $\mathbf{0 . 0 6}(2090-2050)$ & $\mathbf{0 . 0 7}$ & $\mathbf{0 . 2 8}$ \\
\hline
\end{tabular}

\subsubsection{CO desorption}

Figure 4.2a shows IR spectra of linearly adsorbed CO in a TPD experiment on PtYSZ. The first spectrum was taken at $35^{\circ} \mathrm{C}$ (used in Figure 4.1). The peak shifted to lower wave numbers with increasing temperature. This can be explained by reduced dipoledipole coupling, as a result of lower surface coverage of $\mathrm{CO}$ [26]. At $99^{\circ} \mathrm{C}$ the peak maximum was observed at $2070 \mathrm{~cm}^{-1}$. More pronounced loss of intensity was observed when heating above $99^{\circ} \mathrm{C}$ and $\mathrm{CO}$ desorption is completed at $219^{\circ} \mathrm{C}$.

Figure 4.2b shows IR spectra of linearly adsorbed CO on Pt4K700act as a function of temperature. The first spectrum was taken at $25^{\circ} \mathrm{C}$ and shows linear Pt-CO adsorption at $2081 \mathrm{~cm}^{-1}$. The peak was shifted to $2073 \mathrm{~cm}^{-1}$ when increasing temperature to $73^{\circ} \mathrm{C}$, while the peak reduced around $10 \%$ in intensity. More pronounced desorption starts already at $73^{\circ} \mathrm{C}$ and is complete at $89^{\circ} \mathrm{C}$. 


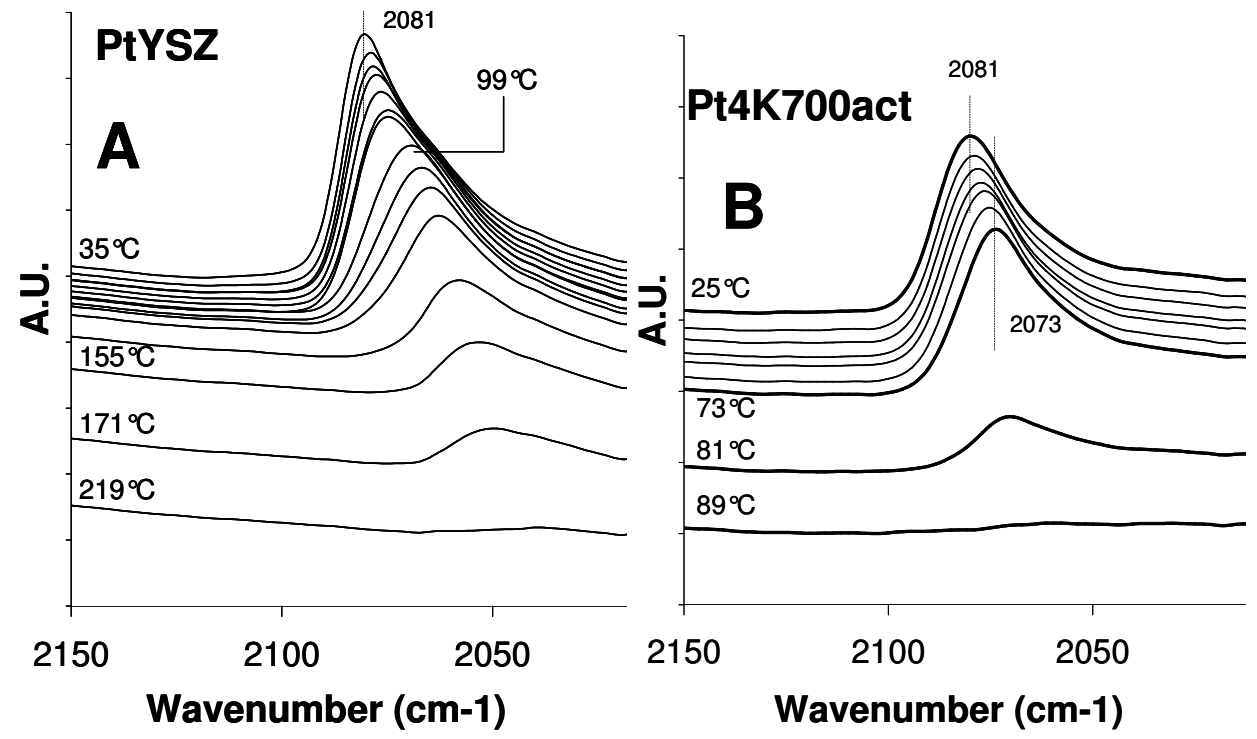

Figure 4.2: CO desorption on PtYSZ (A) and Pt4K700act (B) versus temperature, monitored by Transmission FT-IR spectroscopy. Heating rate was $2^{\circ} \mathrm{C} / \mathrm{min}$ and spectra are shown every $8^{\circ} \mathrm{C}$, unless indicated otherwise in Figure A.

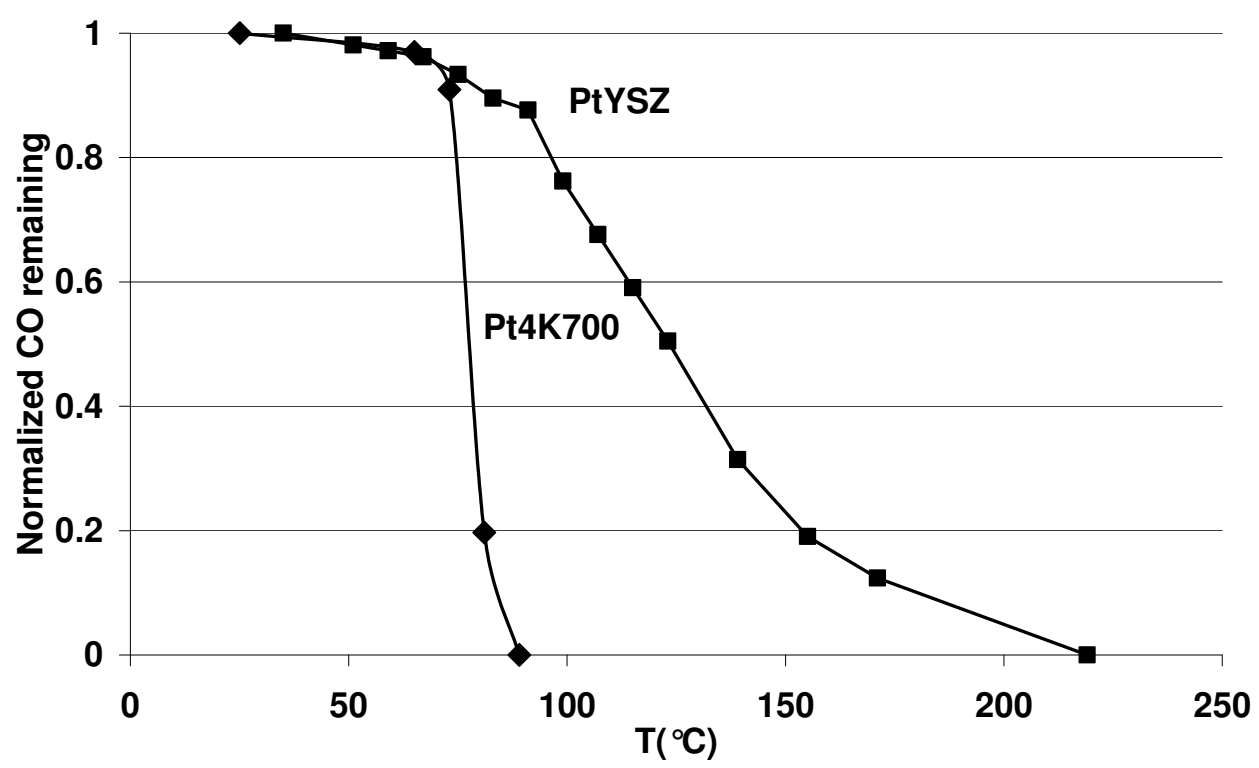

Figure 4.3: Remaining normalized CO on PtYSZ and Pt4K700 as a function of temperature.

Figure 4.3 shows the remaining $\mathrm{CO}$ fraction as a function of temperature obtained by integrating the peak area of the spectra shown in Figures $4.2 \mathrm{a}$ and $4.2 \mathrm{~b}$, defining the initial surface coverage as 1 . On Pt4K700 CO desorption started approximately $25^{\circ} \mathrm{C}$ lower in temperature than on PtYSZ. Desorption of Pt4K700 is completed at $90^{\circ} \mathrm{C}$, 
while on PtYSZ more than $200^{\circ} \mathrm{C}$ is needed to achieve total desorption. Separate TPD experiments in a dedicated TPD apparatus equipped with a mass spectrometer confirmed the difference in temperatures necessary to desorb CO from PtYSZ and Pt4K700 (not shown).

\subsubsection{Catalyst performance}

Table 4.3 shows the reaction rates for methane and ethane as obtained in steam reforming experiments of a mixture of methane $(5 \mathrm{vol} . \%)$ and ethane $(2.2 \mathrm{vol} . \%)$ in argon. The corresponding figures and more detailed results have been published earlier [1] and are reported here for clarity reasons. As shown in Table 4.3, reaction rates for both methane and ethane are increasing on potassium modified catalysts with time on stream. It was also demonstrated that, depending on initial potassium content of the catalysts, stabilization of the rates was reached after 200 to 800 minutes of reforming of the methane and ethane mixture [1]. The experiments reported in this paper are performed on Pt4K700 after the initial activation, thus in stabilized state.

Table 4.3: Reaction rates in mixture of methane (5vol.\%) and ethane (2.2vol.\%) for PtYSZ, Pt4K700act, Pt4K700fresh, Pt4K750act and Pt4K750fresh. Conditions: $200 \mathrm{mg}$ catalyst, 200 $\mathrm{ml} / \mathrm{min}$ total flow, $7^{\circ} \mathrm{C}$, water concentration $12 \mathrm{vol} . \%$

\begin{tabular}{|l|c|c|c|}
\hline Catalyst & $\begin{array}{c}\text { Reaction rate } \mathbf{C H}_{\mathbf{4}} \\
* \mathbf{1 0}^{-\mathbf{6}} \mathbf{( \mathbf { m o l } / \mathbf { g . s } )}\end{array}$ & $\begin{array}{c}\text { Reaction rate } \mathbf{C}_{\mathbf{2}} \mathbf{H}_{\mathbf{6}} \\
* \mathbf{1 0}^{-\mathbf{6}} \mathbf{( \mathbf { m o l } / \mathbf { g . s } )}\end{array}$ & $\begin{array}{c}\text { Ratio of reaction } \\
\text { rates }\left(\mathbf{C H}_{\mathbf{4}} / \mathbf{C}_{\mathbf{2}} \mathbf{H}_{\mathbf{6}}\right)\end{array}$ \\
\hline PtYSZ & 10 & 12 & 0.83 \\
\hline Pt4K700act & 9.4 & 8.5 & 1.11 \\
\hline Pt4K700fresh & 2.1 & 1.9 & 1.11 \\
\hline Pt4K750act & 7.8 & 7.2 & 1.08 \\
\hline Pt4K750fresh & 1. & 1.0 & 1.10 \\
\hline
\end{tabular}

The influence of varying the water concentration on the reaction rates of methane and ethane in the feed was compared on Pt4K700act and PtYSZ. The results for PtYSZ with a mixture of methane (4.5vol.\%) and ethane (1.7vol.\%) are shown in Figure 4.4. 


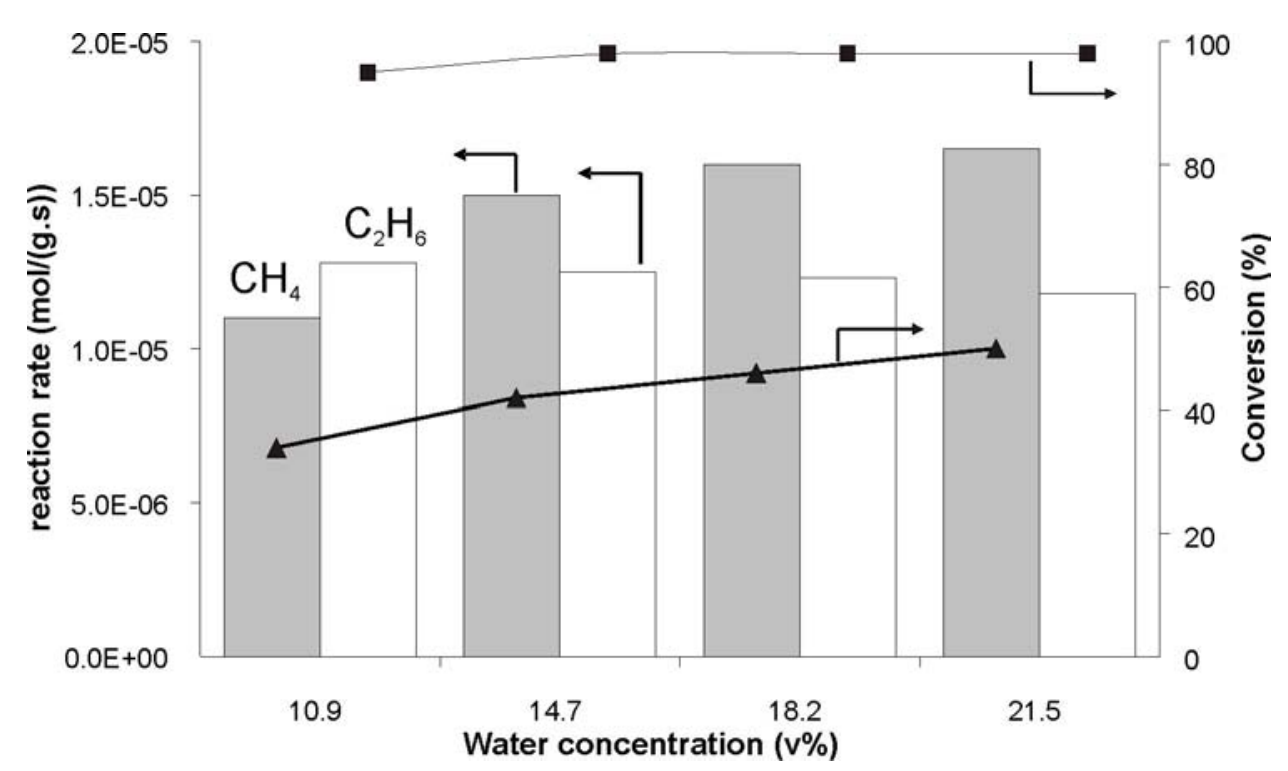

Figure 4.4: Reaction rates (bars) and conversions (markers) in steam reforming of a mixture of methane ( $\triangle, 4.5 \mathrm{vol} . \%)$ and ethane $(\backsim, 1.7 \mathrm{vol} . \%)$ on PtYSZ versus water concentration

It can be seen that the reaction rate of methane is increasing with increasing water concentration. Methane conversion increases from 34 to $50 \%$ when increasing the water concentration from 10.9 to $21.5 \mathrm{vol} . \%$. Ethane conversion was almost complete for water concentrations of $14.7 \mathrm{vol} . \%$ and higher.

It should be noted that by changing the water concentration at identical hydrocarbon concentration, the water to carbon ratio changes, which could influence the reaction rates as well. For this reason, additional experiments were performed to separate effects of ethane concentration and the water to carbon ratio. In the experiments shown in Figure 4.5, water concentration was changed from 12 to $20 \mathrm{vol} \%$, while water/carbon ratio was kept constant at 1.8 by adjusting the ethane concentration. 


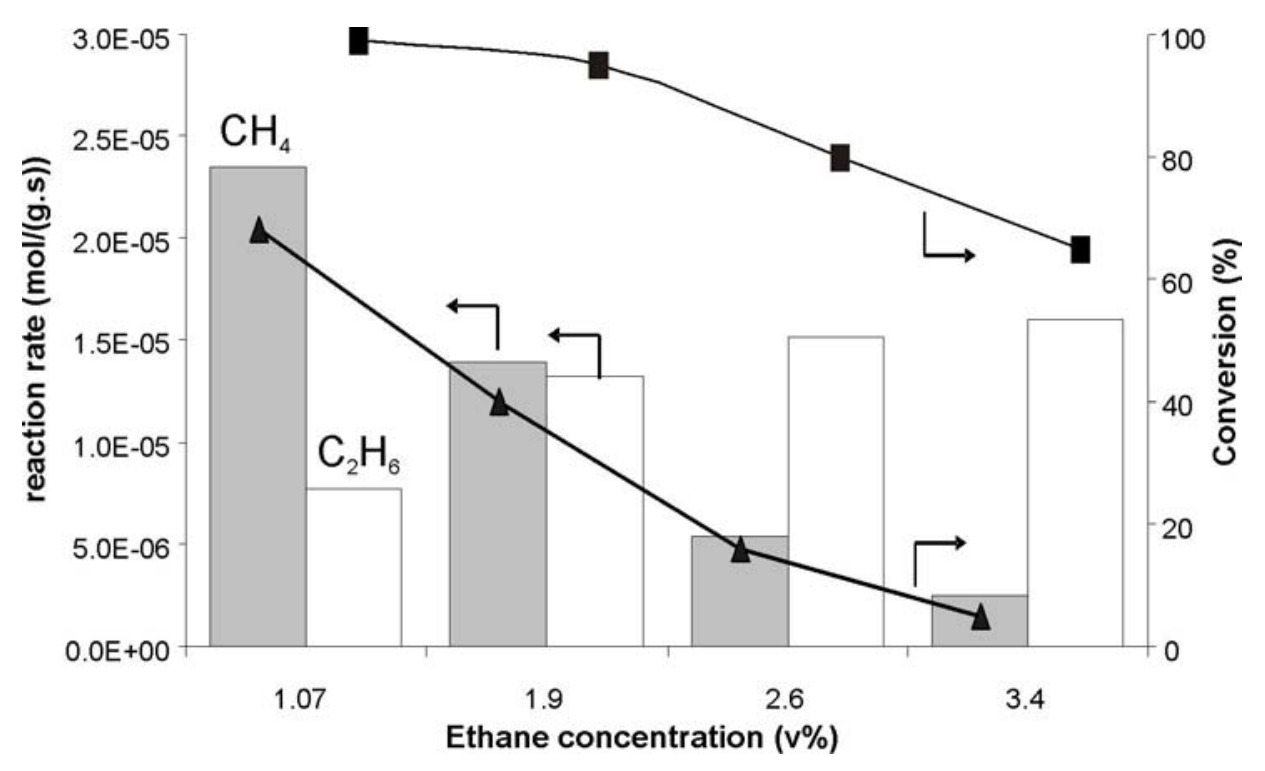

Figure 4.5: Reaction rates (bars) and conversions (markers) in steam reforming of a mixture of methane ( $\triangle, 4.5 \mathrm{vol} . \%)$ and ethane (, 1.07 to 3.4 vol.\%) on PtYSZ. Water/carbon ratio 1.8 and water concentration increased from left to right: $12,15,18$ and 20 vol.\%.

Methane concentration was kept constant at $4.5 \mathrm{vol} . \%$ and ethane was varied between 1.07 and $3.4 \mathrm{vol} . \%$. This means that the methane/ethane feed ratio was changed from 4.3 to 1.3 . At an ethane concentration of $1.07 \mathrm{vol} \%$, a methane reaction rate of 2.3.10 $\mathrm{mol} / \mathrm{g} . \mathrm{s}$ was found, corresponding to a conversion of $68 \%$. Methane conversion was decreasing down to $5 \%$ when ethane concentration was increased to 3.4 vol.\%. It should be noted that the methane concentration was not changed. Ethane conversion level decreased from $98 \%$ at 1.07 vol. $\%$ to $65 \%$ at 3.4 vol. $\%$.

A second series of experiments with constant water concentration (18vol.\%) and constant water to carbon ratio (1.8) was also carried out (not shown). The ratio of methane to ethane feed was changed from 1.1 to 5.7 , keeping the total carbon concentration constant. It was found that the total carbon conversion (calculated in moles of $\mathrm{C}$ converted) increased with increasing methane to ethane ratio (not shown). 


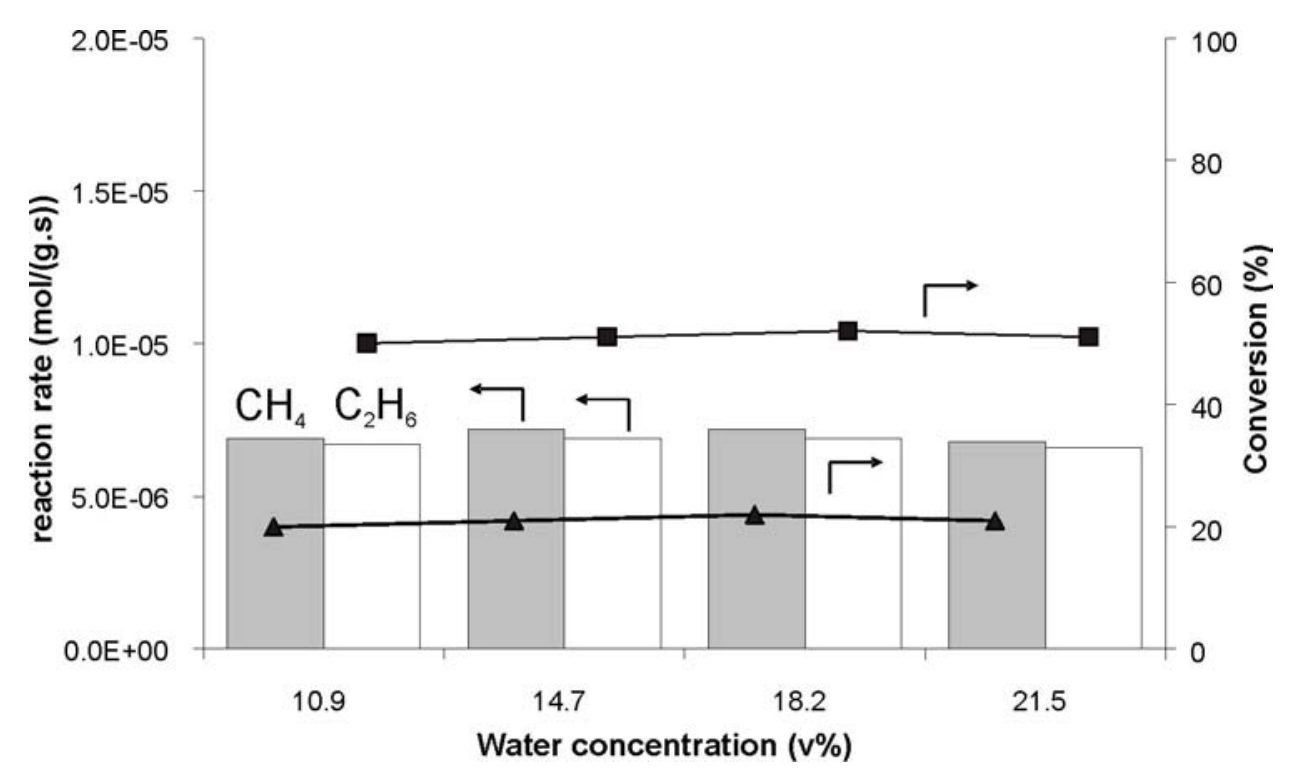

Figure 4.6: Reaction rates (bars) and conversions (markers) in steam reforming of a mixture of methane ( $\square, 4.5$ vol.\%) and ethane $(\triangle, 1.7$ vol.\%) on Pt4K700act versus water concentration

Figure 4.6 shows the influence of varying water concentration in steam reforming of a methane (4.5 vol.\%) and ethane (1.7 vol.\%) mixture on Pt4K700act. Water concentration was varied between 10.9 and $21.5 \mathrm{vol} \%$. In this series of experiments reaction rates of methane and ethane were independent of the water concentration and thus conversions were constant, respectively $49 \%$ for ethane and $22 \%$ for methane. 


\subsection{Discussion}

Potassium modified and unmodified PtYSZ show significant differences in both catalytic performance and characterization with XRD and FT-IR CO adsorption. The implications of the obtained results for steam reforming of methane and ethane will be discussed in the upcoming section.

\subsubsection{Catalyst characterization}

Table 4.1 showed a Pt particle size of $30-40 \mathrm{~nm}$ for all catalysts. The similar particle size of PtYSZ and the potassium modified sample indicates no direct influence of potassium on Pt particle sizes. A similar effect was observed by Juan-Juan on $\mathrm{Ni} / \mathrm{Al}_{2} \mathrm{O}_{3}$ [8]: addition of potassium did not cause any change in Ni-particle size. Further, Table 4.1 shows larger Pt particle size at higher calcination temperature. In general, the calcination temperature affects the size of supported metal particles. High calcination temperatures result in larger metal particles due to increased surface mobility and agglomeration of particles. The difference in Pt particle size between Pt4K700act (30nm) and Pt4K750act (38nm) (Table 4.1) can explain the slightly higher reaction rates for Pt4K700act compared to Pt4K750act (Table 4.3). The activity per Pt surface area unit is identical within 5\% for Pt4K750act and Pt4K700act, assuming hemispherical Pt particles of 38nm and 30nm, respectively. Furthermore, the rates of conversion of ethane and methane are in the same order of magnitude for PtYSZ and potassium modified catalysts under the applied conditions. However, it was observed that methane reaction rate is only 6\% higher on PtYSZ than on Pt4K700act, while ethane reaction rate is $40 \%$ higher on PtYSZ (Table 4.3).

Methane and ethane reaction rates increased over 4 times with time on stream on both potassium modified Pt catalysts, as reported in previous work [1] and summarized in Table 1. It is shown in Table 4.1 that Pt particle size remains unchanged during time on stream for both Pt4K700 and Pt4K750. This clearly shows that activation phenomena do not relate to a change in Pt-particle size and that redistribution of platinum can be excluded. It was further found that the potassium content significantly decreased during activation (shown in Table 4.1), indicating that potassium content and catalyst activity are related. 
FT-IR characterization (Figure 4.1) showed that three different $\mathrm{CO}$ adsorption bands were found in Pt4K700fresh: linear coordinated $\mathrm{CO}$ at $2081 \mathrm{~cm}^{-1}$, a band around $2000 \mathrm{~cm}^{-1}$ due to a direct ion-dipole interaction between $\mathrm{K}^{+}$and linear CO [24, 25], and $\mathrm{CO}$ coordinated in bridged position at $1800 \mathrm{~cm}^{-1}[16]$. Generally, the addition of potassium can lead to an electronic modification of (small) supported metal particles, resulting in a preferred bridge coordination of CO. Interestingly, in this study the average Pt particle size is approximately $30 \mathrm{~nm}$ (Table 4.1), and still an effect of potassium on the CO FT-IR spectra is observed. Because of the large Pt-particles the effect of potassium on adsorbed CO must be localized. Furthermore, potassium loss during the activation period (Table 4.1) led to increased intensity of $\mathrm{CO}$ adsorption at $2081 \mathrm{~cm}^{-1}$ and absence of the bands at 1800 and $2000 \mathrm{~cm}^{-1}$ for Pt4K700act. In addition, linear adsorbed CO on PtYSZ and Pt4K700act are at the same peak position $\left(2081 \mathrm{~cm}^{-1}\right)$, but on PtYSZ this band was 1.5 times more intense than on Pt4K700act. Table 4.1 already showed that Pt particle sizes are around $30 \mathrm{~nm}$ for PtYSZ, Pt4K700fresh and Pt4K700act. All these observations lead to the conclusion that on Pt4K700fresh, the platinum surface is partly covered by potassium, which evaporates during the activation period. As a result the infrared bands at 1800 and $2000 \mathrm{~cm}^{-1}$ disappeared and the intensity at $2081 \mathrm{~cm}^{-1}$ significantly increased. Nevertheless, the lower amount of accessible surface sites on Pt4K700act compared to PtYSZ (Table 4.2) indicates that after activation still parts of Pt surface in Pt4K700act are covered with potassium.

In addition to the potassium loss, a large increase in reaction rates of methane and ethane (Table 4.3) was observed during TOS. The higher reaction rates combined with the increase in accessible metal surface as determined with FTIR, suggest that on $\mathrm{Pt} 4$ K700act hydrocarbon activation on $\mathrm{Pt}$ is rate determining under the present reaction conditions. Moreover, the ratio of reaction rates between methane and ethane clearly increased after potassium addition and remained constant during the activation period on Pt4K700 and Pt4K750 (Table 4.3). For this reason, we propose that initially two types of potassium are present on the potassium modified catalysts. Type I only blocks active Pt sites and is gradually evaporating during activation, as indicated by the increased number of active sites after reaction and absence of the direct $\mathrm{Pt} \mathrm{K}^{+} \mathrm{CO}$ adsorption band at $2000 \mathrm{~cm}^{-1}$ and bridged $\mathrm{CO}$ band at $1800 \mathrm{~cm}^{-1}$ in Pt4K700act. 
Type II is proposed to influence the ratio of reaction rates of methane and ethane. This type of potassium proved to be more stable, as the potassium content did not change during reaction between 20 and 85 hours of time on stream, after activation had taken place [1]. The fact that potassium of type II is not lost, suggests a stronger interaction with either the YSZ support material or with Pt.

\subsubsection{CO desorption in FT-IR TPD}

$\mathrm{CO}$ temperature programmed desorption has been widely studied [27] and used in investigation of catalytic systems [28, 29]. TPD studies in IR spectroscopy have been used earlier by Visser et al. [15]. The intention of their experiments was to relate observations of $\mathrm{CO}$ adsorption strength to reactivity of hydrocarbons found in kinetic experiments, as reported earlier in literature on hydrogenolysis, hydrogenation and oxidation reactions $[13-15,21]$.

Here, it was found in FT-IR and $\mathrm{CO}$ desorption experiments that $\mathrm{CO}$ release from the Pt-surface occurred at lower temperature when potassium was added (Figures 4.2 and 4.3). It was also observed that $\mathrm{CO}$ desorption was completed at lower temperature on Pt4K700 compared to PtYSZ (Figure 4.3). The data convincingly show weaker CO bonding as a result of the addition of potassium.

Kuriyama et al. [17, 30] and Derrouiche et al. [16, 31] also investigated interaction of $\mathrm{CO}$ on potassium modified $\mathrm{Pt} / \mathrm{Al}_{2} \mathrm{O}_{3}$ with FT-IR. Derrouiche reported IR bands on 2.9wt.\% Pt/10wt.\% K/Al ${ }_{2} \mathrm{O}_{3}$ located at $2074 \mathrm{~cm}^{-1}, 1990 \mathrm{~cm}^{-1}$ and $1795 \mathrm{~cm}^{-1}$, comparable to our results in Figure 4.1. The intensity of the peak of linear $\mathrm{CO}$ on $\mathrm{Pt}$ decreased significantly as a result of potassium addition, in agreement with our results in Figure 4.1. TPD experiments by Kuriyama showed complete $\mathrm{CO}$ desorption at about $150^{\circ} \mathrm{C}$ lower temperature on potassium modified $\mathrm{K}-10 \mathrm{wt} . \% / 2 \mathrm{wt} . \% \mathrm{Pt} / \mathrm{Al}_{2} \mathrm{O}_{3}$ as compared to $\mathrm{Pt} / \mathrm{Al}_{2} \mathrm{O}_{3}$, clearly showing weaker adsorption of $\mathrm{CO}$. This is in agreement with our results in Figure 4.3, showing a similar difference of $130^{\circ} \mathrm{C}$ in temperature is needed to achieve complete desorption on Pt4K700 versus PtYSZ.

Derrouiche et al. determined the heat of adsorption with the Adsorption Equilibrium Infrared method (AEIR) on $2.9 \mathrm{wt} . \% \mathrm{Pt} / 10 \mathrm{wt} . \% \mathrm{~K} / \mathrm{Al}_{2} \mathrm{O}_{3}$ [16] and reported a significant decrease in heat of adsorption of linear CO species and a strong increase in heat of adsorption for bridged $\mathrm{CO}$ species as a result of potassium addition to $\mathrm{Pt}$. This 
completely agrees with our results in Figure 4.3, showing a weaker interaction for linear CO species at $2081 \mathrm{~cm}^{-1}$ on Pt4K700act, which had only linear CO species present on the surface (Figure 4.1). Obviously, the C-O stretch frequency, which is identical for PtYSZ and Pt4K700act, does not reflect the Pt-CO bond strength.

Bengaard et al. [32] observed weaker adsorption of hydrocarbons on Ni catalysts after adding potassium: a strong decrease in methane adsorption was found when potassium was added, resulting in slow hydrogen-deuterium exchange for methane compared to the unmodified catalyst Ni-catalyst. Cassuto et al. found more loosely bonded ethylene on potassium modified platinum surfaces [33]. Summarizing the results in literature, it is claimed that hydrocarbon adsorption on $\mathrm{Pt}$ can be weakened by addition of potassium to $\mathrm{Pt}$ or $\mathrm{Ni}$ catalysts. We propose, based on our results on $\mathrm{CO}$ desorption, that weakening of hydrocarbon adsorption occurs when modifying PtYSZ with potassium. The effects on kinetics on PtYSZ and Pt4K700 will be discussed below.

\subsubsection{Steam reforming reaction mechanism on PtYSZ}

For methane reforming, Wei et al $[34,35]$ proposed dissociative adsorption as the rate determining step in methane activation: $\mathrm{CH}_{4}$, gas $\rightarrow \mathrm{CH}_{3(\mathrm{ads})}+\mathrm{H}_{(\text {ads) }}$. This means that the hydrocarbon surface coverage is low and reaction proceeds rapidly after dissociation of methane. Reaction to $\mathrm{CO}$ occurs as soon as the carbon atom is completely dehydrogenated. In literature, debate exists about the activation of water on Pt catalysts in steam reforming at high temperature: several sources claim a bi-functional mechanism for reforming reactions on $\mathrm{Pt}$, proposing hydrocarbon activation on the $\mathrm{Pt}$ atoms and water activation on the support [36-38]. On the other hand, Wei and Iglesia [34, 39, 40] argued that water activation is a relatively fast step, implying that the question on which sites water is activated is not relevant for reaction kinetics.

To the best of our knowledge no detailed mechanism has been reported for steam reforming of ethane, but ethane hydrogenolysis has been investigated in detail on $\mathrm{Pt}$ and Ni catalysts. [41-43]. It was reported that activity trends in steam reforming and ethane hydrogenolysis are comparable on supported Ni-catalysts [9], suggesting similar mechanisms for ethane activation in both reactions. In hydrogenolysis, 
activation of ethane on $\mathrm{Pt}$ or $\mathrm{Ni}$ takes place through dissociative adsorption on the surface (1), creating adsorbed ethylidyne and an hydrogen atom [41-43]:

$\begin{array}{lllll}\mathrm{C}_{2} \mathrm{H}_{6} & \rightarrow & \mathrm{CH}_{3} \mathrm{CH}_{2(\mathrm{ads})} & + & \mathrm{H}_{(\mathrm{ads})} \\ \mathrm{CH}_{3} \mathrm{CH}_{2(\text { ads })} & \rightarrow & \mathrm{CH}_{2(\text { ads })} & + & \mathrm{CH}_{3(\mathrm{ads})} \\ \mathrm{CH}_{3} \mathrm{CH}_{2(\text { ads })} & \rightarrow & \mathrm{CH}_{2} \mathrm{CH}_{2(\mathrm{ads})} & + & \mathrm{H}_{(\mathrm{ads})} \\ \mathrm{CH}_{3} \mathrm{CH}_{2(\text { ads })} & \rightarrow & \mathrm{CH}_{3} \mathrm{CH}_{(\mathrm{ads})} & + & \mathrm{H}_{(\mathrm{ads})} \\ \mathrm{CH}_{3} \mathrm{CH}_{(\text {ads })} & \rightarrow & \mathrm{CH}_{3} \mathrm{C}_{(\text {ads })} & + & \mathrm{H}_{(\mathrm{ads})}\end{array}$

Two pathways are possible after formation of the $\mathrm{CH}_{3} \mathrm{CH}_{2}$ fragment: (i) the $\mathrm{CH}_{3} \mathrm{CH}_{2}$ fragment can either split into a $\mathrm{CH}_{3}$ and a $\mathrm{CH}_{2}$ fragment after adsorption (2) or (ii) further abstraction of hydrogen atoms can occur $(3 a+3 b+3 c)[41,42]$. Both processes require additional empty surface sites. The $\mathrm{C}-\mathrm{C}$ splitting is favored for the $\mathrm{CH}_{3} \mathrm{CH}_{2}$ fragment on Pt [41, 42]. After C-C splitting, further dehydrogenation of $\mathrm{CH}_{\mathrm{x}}$ can occur, similar to the mechanism for methane, and subsequent conversion to $\mathrm{CO}$ is possible as explained above.

If further abstraction of hydrogen atoms on $\mathrm{CH}_{3} \mathrm{CH}_{2}$ fragments occurs $(3 \mathrm{a}+3 \mathrm{~b}+3 \mathrm{c})$, much less reactive surface intermediates are formed, occupying the Pt sites. It is claimed that $\mathrm{CCH}_{3}$-fragments on the Pt surface are the most stable species that block the Pt surface sites [41, 42]. Very low reactivity of the $\mathrm{CCH}_{3}$-species on the surface was also reported by Anderson et al. [44] in ethylene dehydrogenation on platinum.

Our study focused on steam reforming of methane/ethane mixtures, requiring activation of both hydrocarbons on PtYSZ. Competition between methane and ethane in steam reforming was observed on PtYSZ (Figure 4.5). This leads to the proposition that methane and ethane are indeed activated on the same Pt-sites. The water concentration was also found to influence reaction rates in ethane/methane mixtures on PtYSZ as shown in Figure 4: higher reaction rates with increasing water concentration show that water activation on this catalyst is a limiting factor. This suggests that the Pt surface is highly covered with fragments originating from dissociative adsorption of methane and/or ethane. 
The results in Figure 4.5 show that the relative increase of the reaction rates with higher water concentration is smaller than the decreasing effects caused by the increasing ethane concentration. This is confirmed by the total molar carbon conversion in the experiments of Figure 4.5, as shown in Table 4.4 (reaction of methane counts for one carbon atom converted, while ethane counts for two atoms). With higher ethane concentration in the feed, the percentage of carbon converted is decreasing, even when the water concentration is increased proportionally. Figure 4.5 thus shows that the methane reaction rate strongly decreased if more ethane is present, and that high methane conversions are only possible if ethane is converted completely, confirming competition between methane and ethane on the platinum surface.

Table 4.4: Total number of carbon atoms converted in the experiments shown in Figure 4.5, $\mathrm{CH}_{4}$ (4.5vol.\%), $\mathrm{H}_{2} \mathrm{O} / \mathrm{C}$ ratio 1.8:

\begin{tabular}{|l|c|c|c|c|}
\hline Water (vol.\%) & 12 & 15 & 18 & 20 \\
\hline Ethane (vol.\%) & 1.07 & 1.9 & 2.6 & 3.4 \\
\hline Total C conversion $\left(.10^{-5} \mathrm{~mol} / \mathrm{g} . \mathrm{s}\right)$ & 3.1 & 4.0 & 3.6 & 3.5 \\
\hline Carbon converted $(\%)$ & 46.7 & 48.2 & 37.1 & 31.0 \\
\hline
\end{tabular}

Furthermore, in Figure 4.5, ethane conversion decreased from 98\% at 1.07 vol.\% to $65 \%$ at $3.4 \mathrm{vol} . \%$, implying that the apparent reaction order in ethane is smaller than 1. This indicates a self poisoning effect due to blocking of active sites by ethane fragments. The creation of stable $\mathrm{C}_{2}$ intermediates as reported by Cortright $[41,42]$ on the Pt-surface could be a reason for limited adsorption and activation of methane at higher ethane concentrations (Figure 4.5). Higher ethane concentrations create more stable $\mathrm{C}_{2}$-fragments on the Pt-surface, leaving a lower percentage of the active sites open for methane dissociation and reaction to $\mathrm{CO}$ and $\mathrm{H}_{2}$. It is concluded that ethane induces a high surface coverage of $\mathrm{C}_{2} \mathrm{H}_{\mathrm{y}}$ fragments and water activation becomes the rate limiting step in mixtures of methane and ethane on PtYSZ. 


\subsubsection{Steam reforming reaction mechanism on Pt4K700}

The addition of potassium could affect the reaction rates of methane and ethane in steam reforming in two ways: potassium either influences the activation of water or modifies the activation of the hydrocarbons, methane and ethane. In literature it is stated that potassium can indeed enhance water activation on the support [45, 46], but as indicated earlier, there is no agreement in literature on the kinetic relevance of water activation on the support on steam reforming [34-38, 40].

In our experiments with Pt4K700, it was observed that a changing water concentration had no influence on reaction rates for both methane and ethane (Figure 4.6), in contrast to PtYSZ (Figure 4.4). With the addition of potassium to PtYSZ, the competition between ethane and methane was diminished, as reported in an earlier paper [1]. First order kinetics in methane and ethane were reported, indicating low surface coverage of both hydrocarbons, even in mixtures of methane and ethane. The apparent first order in both methane and ethane suggests that hydrocarbon activation on $\mathrm{Pt}$ is the limiting step on Pt4K700 and activation of water is not kinetically relevant, as observed in Figure 4.6. The conclusion that hydrocarbon activation is rate limiting on Pt4K700 is also in agreement with the observation that increasing the number of accessible Pt sites with TOS (Figure 4.1) is accompanied by an increase in catalytic activity.

In an earlier paper [1], a lower activity was reported for the potassium modified catalysts during steam reforming of the single hydrocarbons ethane and methane, as compared to the unmodified PtYSZ catalyst. For methane the activity decreased by $60 \%$, while for ethane reaction rate decreased by $33 \%$. The IR experiments in this work indicate that potassium weakens the interaction with methane and ethane, leading to lower surface coverages of methane and ethane. The lower surface coverages can explain the observed lower reaction rates of methane and ethane on Pt4K700 as compared to PtYSZ.

Interestingly, contrary to the rate limiting step found for PtYSZ, the rate limiting step of hydrocarbon activation on Pt4K700 is well in agreement with the mechanism proposed by Wei and Iglesia [34, 35, 40]; competition effects as observed on PtYSZ, leading to high surface coverage, were eliminated on potassium modified catalysts. In 
conclusion, our results show that adsorption for both ethane and methane was reduced on potassium modified PtYSZ. Blocking effects by ethane as observed on PtYSZ could be eliminated by reducing the alkane adsorption strength. However, this also resulted in reduced adsorption of methane, leading to lower reactivity for both hydrocarbons. 


\subsection{Conclusion}

Potassium modification of PtYSZ strongly influenced the conversion and rate determining steps in methane and ethane in steam reforming. Water activation is the rate determining step on PtYSZ, resulting in high surface coverage of hydrocarbon fragments during steam reforming of mixtures of methane and ethane. This led to blocking of active sites by ethane fragments and consequently low conversion of methane. If potassium is added to the catalyst, hydrocarbon activation on $\mathrm{Pt}$ is rate determining, resulting in low surface coverage of methane and ethane. As a result, competition effects of methane and ethane diminished on potassium modified PtYSZ, enabling simultaneous conversion of methane and ethane. The weaker interaction of the hydrocarbons with the Pt surface due to potassium addition is also reflected in the lower adsorption strength of $\mathrm{CO}$ as found with CO FT-IR TPD. 


\subsection{References}

[1] P.O. Graf, B.L. Mojet, L. Lefferts, Applied Catalysis A: General In Press, Accepted Manuscript.

[2] P.O. Graf, B.L. Mojet, J.G. van Ommen, L. Lefferts, Applied Catalysis A: General 332 (2007) 310-317.

[3] D.L. Trimm, Catalysis Today 37 (1997) 233.

[4] J.H. Bitter, W. Hally, K. Seshan, J.G. van Ommen, J.A. Lercher, Catalysis Today 29 (1996) 349-353.

[5] J.H. Bitter, K. Seshan, J.A. Lercher, Journal of Catalysis 171 (1997) 279.

[6] M.E.S. Hegarty, A.M. O'Connor, J.R.H. Ross, Catalysis Today 42 (1998) 225.

[7] A.M. O'Connor, J.R.H. Ross, Catalysis Today 46 (1998) 203.

[8] J. Juan-Juan, M.C. Roman-Martinez, M.J. Illan-Gomez, Applied Catalysis A: General 301 (2006) 9-15.

[9] J.R. Rostrup-Nielsen, Journal of Catalysis 31 (1973) 173.

[10] J. Sehested, Catalysis Today 111 (2006) 103-110.

[11] J.W. Snoeck, G.F. Froment, M. Fowles, Industrial and Engineering Chemistry Research 41 (2002) 3548-3556.

[12] D.L. Trimm, Catalysis Today 49 (1999) 3.

[13] B.L. Mojet, J.T. Miller, D.E. Ramaker, D.C. Koningsberger, Journal of Catalysis 186 (1999) 373-386.

[14] M.K. Oudenhuijzen, J.A. Van Bokhoven, D.E. Ramaker, D.C. Koningsberger, Journal of Physical Chemistry B 108 (2004) 20247-20254.

[15] T. Visser, T.A. Nijhuis, A.M.J. Van Der Eerden, K. Jenken, Y. Ji, W. Bras, S. Nikitenko, Y. Ikeda, M. Lepage, B.M. Weckhuysen, Journal of Physical Chemistry B 109 (2005) 3822-3831.

[16] S. Derrouiche, P. Gravejat, B. Bassou, D. Bianchi, Applied Surface Science 253 (2007) 5894-5898.

[17] M. Kuriyama, H. Tanaka, S.-i. Ito, T. Kubota, T. Miyao, S. Naito, K. Tomishige, K. Kunimori, Journal of Catalysis 252 (2007) 39-48.

[18] E.L. Garfunkel, J.E. Crowell, G.A. Somorjai, Journal of Physical Chemistry 86 (1982) 310-313.

[19] P.A.J.M. Angevaare, H.A.C.M. Hendrickx, V. Ponec, Journal of Catalysis 110 (1988) 11-17.

[20] H.P. Bonzel, Surface Science Reports 8 (1988) 43-125.

[21] A.Y. Stakheev, Y. Zhang, A.V. Ivanov, G.N. Baeva, D.E. Ramaker, D.C. Koningsberger, Journal of Physical Chemistry C 111 (2007) 3938-3948.

[22] H. Borchert, E.V. Shevchenko, A. Robert, I. Mekis, A. Kornowski, G. Grubel, H. Weller, Langmuir 21 (2005) 1931-1936.

[23] S.D. Jackson, B.M. Glanville, J. Willis, G.D. McLellan, G. Webb, R.B. Moyes, S. Simpson, P.B. Wells, R. Whyman, Journal of Catalysis 139 (1993) 221-233.

[24] M.J. Kappers, J.T. Miller, D.C. Koningsberger, J. Phys. Chem. 100 (1996) 3227-3236.

[25] A.Y. Stakheev, E.S. Shpiro, N.I. Jaeger, G. Schulz-Ekloff, Catalysis Letters 32 (1995) 147-158.

[26] P. Hollins, J. Pritchard, Progress in Surface Science 19 (1985) 275-349.

[27] D.A. King, 1 ed., Utrecht, Netherlands, 1975, Surf. Sci. (Netherlands) Vol.47, pp. 384-402. 
[28] A.M. de Jong, J.W. Niemantsverdriet, Vacuum 41 (1990) 232-233.

[29] D.L.S. Nieskens, A.P. Van Bavel, J.W. Niemantsverdriet, Surface Science 546 (2003) 159-169.

[30] Y. Minemura, M. Kuriyama, S.-i. Ito, K. Tomishige, K. Kunimori, Catalysis Communications 7 (2006) 623-626.

[31] P. Pillonel, S. Derrouiche, A. Bourane, F. Gaillard, P. Vernoux, D. Bianchi, Applied Catalysis A: General 278 (2005) 223-231.

[32] H.S. Bengaard, J.K. Norskov, J. Sehested, B.S. Clausen, L.P. Nielsen, A.M. Molenbroek, J.R. Rostrup-Nielsen, Journal of Catalysis 209 (2002) 365-384.

[33] A. Cassuto, S. Schmidt, M. Mane, Surface Science 284 (1993) 273-280.

[34] J.M. Wei, E. Iglesia, Journal of Catalysis 225 (2004) 116.

[35] J.M. Wei, E. Iglesia, Journal of Physical Chemistry B 108 (2004) 4094.

[36] K. Nagaoka, K. Seshan, K. Aika, J.A. Lercher, Journal of Catalysis 197 (2001) 34.

[37] K. Takanabe, K.-i. Aika, K. Inazu, T. Baba, K. Seshan, L. Lefferts, Journal of Catalysis 243 (2006) 263-269.

[38] B. Matas Guell, I. Babich, K. Seshan, L. Lefferts, Journal of Catalysis 257 (2008) 229-231.

[39] J. Wei, E. Iglesia, Journal of Physical Chemistry B 108 (2004) 4094-4103.

[40] J.M. Wei, E. Iglesia, Physical Chemistry Chemical Physics 6 (2004) 3754.

[41] R.D. Cortright, R.M. Watwe, J.A. Dumesic, Journal of Molecular Catalysis, A: Chemical 163 (2000) 91-103.

[42] R.D. Cortright, R.M. Watwe, B.E. Spiewak, J.A. Dumesic, Catalysis Today 53 (1999) 395.

[43] M.C. McMaster, R.J. Madix, Surface Science 275 (1992) 265-280.

[44] A.B. Anderson, S.J. Choe, Journal of Physical Chemistry 93 (1989) 6145-6149.

[45] F. Frusteri, S. Freni, V. Chiodo, L. Spadaro, O. Di Blasi, G. Bonura, S. Cavallaro, Applied Catalysis A: General 270 (2004) 1-7.

[46] D. Sutton, B. Kelleher, J.R.H. Ross, Fuel Processing Technology 73 (2001) 155173. 


\title{
Chapter
}

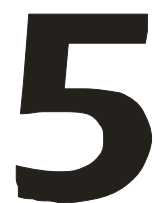

\section{Reactive separation of ethylene from the effluent gas of methane oxidative coupling via alkylation of benzene to ethylbenzene on ZSM-5}

\begin{abstract}
Separation of ethylene from the effluent gas of oxidative coupling has been a challenging issue for several years. In a combined process of oxidative coupling and reforming of methane, reactive separation of ethylene via alkylation of benzene to ethylbenzene (EB) is a promising option. Ethylene was successfully converted to the useful chemical intermediate ethylbenzene using ZSM-5. Yields of EB up to $90 \%$ were found at $95 \%$ conversion and $90 \%$ selectivity at $360^{\circ} \mathrm{C}$. Methane and ethane present in the feed were not converted and can be used for steam reforming in the proposed reaction concept. None of the additional components present in the effluent gas of oxidative coupling $\left(\mathrm{CO}, \mathrm{CO}_{2}, \mathrm{CH}_{4}, \mathrm{C}_{2} \mathrm{H}_{6}\right.$ and $\left.\mathrm{H}_{2} \mathrm{O}\right)$ influences activity or selectivity of the alkylation catalyst. Stability of ZSM-5 is also not influenced by the added components, with the exception of water, which even increases stability.
\end{abstract}




\subsection{Introduction}

With the depletion of petroleum, it is expected that methane will eventually become a major resource for chemicals and liquid fuels. Much of the methane is found in regions that are far removed from industrial complexes and often located offshore, implying that transport is uneconomical or even impossible. This has led to worldwide efforts for directly converting methane into easy transportable value-added products. An interesting option is the slightly exothermic oxidative coupling of methane (1), with the highly exothermic complete oxidation to $\mathrm{CO}_{2}$ and $\mathrm{H}_{2} \mathrm{O}$ as side reaction (2), as reviewed by Choudhary et al [1].

$$
\begin{array}{lll}
\mathrm{CH}_{4}+1 / 2 \mathrm{O}_{2} \rightarrow 1 / 2 \mathrm{C}_{2} \mathrm{H}_{4}+\mathrm{H}_{2} \mathrm{O} & \Delta \mathrm{H}^{\circ}{ }_{298} & =-140 \mathrm{~kJ} / \mathrm{mol} \\
\mathrm{CH}_{4}+2 \mathrm{O}_{2} \rightarrow \mathrm{CO}_{2}+2 \mathrm{H}_{2} \mathrm{O} & \Delta \mathrm{H}^{\circ}{ }_{298} & =-801 \mathrm{~kJ} / \mathrm{mol}
\end{array}
$$

A high selectivity to reaction (1) is always compromised with a low methane conversion. This means that the product stream after oxidative coupling will be a complex gas mixture consisting of the main product ethylene, combined with $\mathrm{C}_{2} \mathrm{H}_{6}$, $\mathrm{CH}_{4}, \mathrm{CO}, \mathrm{CO}_{2}, \mathrm{H}_{2} \mathrm{O}$ and small amounts $\mathrm{H}_{2}$. Efficient separation of ethylene or creative ideas in process operation are needed to make the oxidative coupling commercially feasible.

The limitations of the oxidative coupling have led to development of several alternatives. Makri et al. used a gas recycle reactor [2], Choudhary proposed the use of a countercurrent moving bed [1]. Also research on plasma [3] and solid-state electrolyte reactors [4] has been carried out. Additionally combinations with other reactions have been proposed: catalytic oxidative coupling and gas phase partial oxidation [5], co-generation of ethylene and electricity through oxidative coupling [6], oxidative coupling of methane and oxidative dehydrogenation [7] and oxidative coupling of methane and pyrolysis of naphtha [8]. All of the processes face difficulties with economic and/or technical feasibility. Operation of oxidative coupling can be optimized by distributed feeding of oxygen $[9,10]$.

The objective of the current research is to create an autothermal process, combining the exothermic oxidative coupling of methane (1) and side combustion reactions (2) with the endothermic methane steam and dry reforming $(3+4)$. The intention is to 
convert methane to ethylene and synthesis gas $\left(\mathrm{CO}\right.$ and $\left.\mathrm{H}_{2}\right)$ in one multifunctional reactor. The essential advantage of this proposition as compared to the options listed above is the elimination of the methane recycle, because methane left unconverted in oxidative coupling is now converted via reforming.

$$
\begin{array}{lll}
\mathrm{CH}_{4}+\mathrm{H}_{2} \mathrm{O} \rightarrow 3 \mathrm{H}_{2}+\mathrm{CO} & \Delta \mathrm{H}^{\circ}{ }_{298} & =206 \mathrm{~kJ} / \mathrm{mol} \\
\mathrm{CH}_{4}+\mathrm{CO}_{2} \rightarrow 2 \mathrm{H}_{2}+2 \mathrm{CO} & \Delta{\mathrm{H}^{\circ}}_{298}=247 \mathrm{~kJ} / \mathrm{mol}
\end{array}
$$

Direct methane steam reforming of the product mixture of oxidative coupling (containing $\mathrm{C}_{2} \mathrm{H}_{4}, \mathrm{C}_{2} \mathrm{H}_{6}, \mathrm{CH}_{4}, \mathrm{CO}, \mathrm{CO}_{2} \mathrm{H}_{2} \mathrm{O}$ and $\mathrm{H}_{2}$ ) resulted in a loss of $\mathrm{C}_{2} \mathrm{H}_{4}$ and $\mathrm{C}_{2} \mathrm{H}_{6}$, as those components are also converted in steam reforming [11, 12]. Ethylene is the desired product and conversion to synthesis gas should therefore be avoided.

A process combining oxidative coupling and reforming of methane can still be valuable in terms of heat integration of the reactions, provided that ethylene is separated before steam reforming of the mixture produced in oxidative coupling. Cryogenic distillation has been considered for separation: the process takes place at around $-160^{\circ} \mathrm{C}$ [13] and a flow sheet of OCM separation was demonstrated by Vereshchagin et al. [14]. A major drawback is the enormous temperature difference between oxidative coupling and this separation technique. An alternative separation technique is selective adsorption of ethylene on molecular sieves [2] or active charcoal [15]. However, disadvantages of this option are trapping of $\mathrm{H}_{2} \mathrm{O}$ and $\mathrm{CO}_{2}$ and the fact that desorption of ethylene requires a carrier gas, resulting in an inert carrier with only $1 \% \mathrm{C} 2$ content. Additionally, the adsorption process takes place at room temperature, which implies a large temperature difference with the oxidative coupling conditions.

A novel approach presented in this paper could be a reactive separation of ethylene, combining separation of ethylene and production of a useful product. The separation of ethylene by reaction with benzene to ethylbenzene (EB) could be promising as ethylbenzene is an important intermediate in styrene production. Benzene alkylation has been reported in vapor and liquid phase on various zeolite catalysts mostly under high pressure [16-24]. In our case it is important to operate benzene alkylation at 
conditions similar to the conditions of oxidative coupling, i.e. $700^{\circ} \mathrm{C}$ and close to atmospheric pressure implying operation in gas phase.

In a review by Perego et al., several catalysts for benzene alkylation are compared [25]. ZSM-5 based catalysts are frequently used in vapor phase alkylation and offer low coking tendency and therefore long life cycles between regeneration are possible [26]. Excess benzene is applied to ensure high conversion of ethylene and selectivity to ethylbenzene, limiting di- or tri-alkylation [25, 27, 28]. Also toluene is reported as a byproduct [28].

The goal of this research paper is to demonstrate reactive separation of ethylene from the mixture produced in oxidative coupling, via alkylation of benzene. Yield of ethylbenzene, conversion of hydrocarbons (i.e. methane, ethane and ethylene) and selectivity to ethylbenzene will be reported for temperatures between $320^{\circ} \mathrm{C}$ and $440^{\circ} \mathrm{C}$. Furthermore, the effects of byproducts of oxidative coupling $\left(\mathrm{CO}, \mathrm{CO}_{2}\right.$ and $\mathrm{H}_{2} \mathrm{O}$ ) on benzene alkylation will be investigated, as $\mathrm{CO}_{2}$ and $\mathrm{H}_{2} \mathrm{O}$ are claimed to affect stability of alkylation of benzene [29]. 


\subsection{Experimental}

ZSM-5 with Si/Al ratio of 28 containing $\mathrm{NH}_{4}{ }^{+}$cations was used (Exxon). Before activity test, ZSM-5 was heated to $400^{\circ} \mathrm{C}$ in argon and calcined for 5 hours in 20 vol.\% $\mathrm{O}_{2}$ (Linde Gas 5.0) / Ar (Linde Gas 5.0, flow rate: 200ml/min). Activity tests were carried out in a micro reactor flow setup with $200 \mathrm{mg}$ of catalyst. The reactor consisted of a quartz tube with inner and outer diameter of respectively 4 and $6 \mathrm{~mm}$. About 200mg catalyst was loaded in the reactor, held between quartz wool plugs. Catalyst particles with a diameter between 0.3 and $0.6 \mathrm{~mm}$ were used, resulting in a pressure drop around 0.1 bar.

Methane (Hoekloos 4.5), ethane (Indugas 4.0) and ethylene (Indugas 3.5) were used as hydrocarbon feedstock. Benzene (pro analysi, Alfa-Aesar 99.7\%) was fed with a Bronkhorst controlled evaporator mixer (CEM) in combination with a Liquiflow controller. The reaction mixtures had the following composition: $4.3 \mathrm{vol} \% \mathrm{C}_{2} \mathrm{H}_{4}$, 3 vol. $\% \mathrm{C}_{2} \mathrm{H}_{6}, 5 \mathrm{vol} . \% \mathrm{CH}_{4}, 30 \mathrm{vol} . \% \mathrm{C}_{6} \mathrm{H}_{6}$ in Ar. A total flow rate of $70 \mathrm{ml}^{-\mathrm{min}^{-1}}$ was applied. $\mathrm{H}_{2} \mathrm{O}$, $\mathrm{CO}$ (Linde Gas 4.7) and $\mathrm{CO}_{2}$ (Linde Gas 4.0) were added to this mixture. Water was added through a double saturation step of the gas mixture. In a first saturator the gas stream was contacted with water at $60^{\circ} \mathrm{C}$, followed by condensation at $50^{\circ} \mathrm{C}$ in a second saturator. This led to a stable water concentration of 6vol.\%.

The product and reactant gas composition was analyzed with a Varian 3800 Gas Chromatograph equipped with two columns (Molsieve 5A and PoraPlotQ) and two TCD detectors. 1,2 di-ethylbenzene and 1,4 di-ethylbenzene could be separated and analyzed in the PoraPlotQ column. A Balzers QMS 200 F mass spectrometer was used to check for higher alkylated benzenes or other by products. Conversion (X), selectivity $\left(\mathrm{S}_{\mathrm{i}}\right)$ and yield $\left(\mathrm{Y}_{\mathrm{i}}\right)$ were determined based on ethylene conversion, ethylbenzene (EB) and di-ethylbenzene (DEB) concentrations. Concentrations were corrected for volume changes of the reaction mixture, using Ar as internal standard. The calculations shown below are carried out with the amounts of reactants and products expressed in mole/sec. 


$$
\begin{aligned}
& X=1-\frac{C_{2} H_{4} \text { out }}{C_{2} H_{4} i n} \\
& S_{E B}=\frac{E B}{E B+1,4 D E B+1,2 D E B}, \quad S_{D E B}=\frac{1,4 D E B+1,2 D E B}{E B+1,4 D E B+1,2 D E B} \\
& Y_{i}=S_{i} * X
\end{aligned}
$$

HSC Chemistry 4.0 software was used to calculate equilibrium compositions of the reaction mixtures including di-ethylbenzenes. 


\subsection{Results}

\subsubsection{Conversion of $\mathrm{C}_{2} \mathrm{H}_{4}$, selectivity and yield to EB}

Figure 5.1 shows the results of benzene alkylation experiments with a feed composition of 30vol.\% $\mathrm{C}_{6} \mathrm{H}_{6}, 4.3 \mathrm{vol} . \% \mathrm{C}_{2} \mathrm{H}_{4}, 3 \mathrm{vol} . \% \mathrm{C}_{2} \mathrm{H}_{6}$ and 5vol.\% $\mathrm{CH}_{4}$ in $\mathrm{Ar}$. The total flow rate was $70 \mathrm{ml} \cdot \mathrm{min}^{-1}$. The data points were obtained in random order. The catalyst was regenerated by exposure to $20 \mathrm{vol} . \% \mathrm{O}_{2}$ during $15 \mathrm{~min}$ at $400^{\circ} \mathrm{C}$ just before acquiring the data points at every temperature, in order to compensate for any deactivation (as will be discussed in Figure 5.3). The initial performance is reported in Figure 5.1.

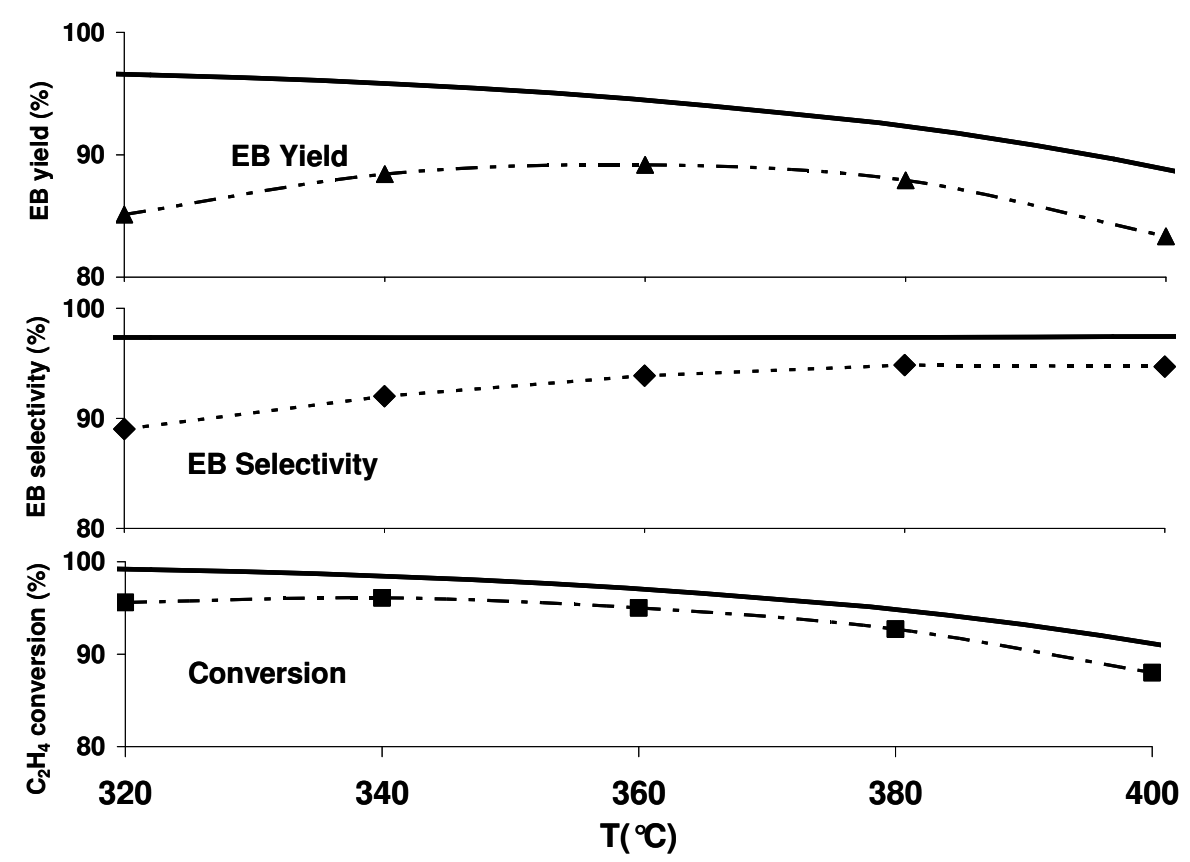

Figure 5.1: Comparison of experimental ethylene conversion (below), Ethylbenzene (EB) selectivity (middle) and EB yield (above) and thermodynamic equilibrium (solid line) in alkylation of benzene as a function of temperature. Concentrations: $30 \mathrm{vol} . \% \mathrm{C}_{6} \mathrm{H}_{6}, 4.3 \mathrm{vol} . \%$ $\mathrm{C}_{2} \mathrm{H}_{4}, 3 \mathrm{vol} . \% \mathrm{C}_{2} \mathrm{H}_{6}$ and 5 vol\% $\mathrm{CH}_{4}$ in $\mathrm{Ar}$ (total flow rate 70ml.min ${ }^{-1}$ ).

In all experiments in this work, no significant conversion of methane and ethane was observed (concentration changes in these components were smaller than 1\%). Around $96 \%$ initial ethylene conversion was found at $320^{\circ} \mathrm{C}$ and $340^{\circ} \mathrm{C}$, decreasing to $90 \%$ at $400^{\circ} \mathrm{C}$. Thermodynamic equilibrium predicts $99 \%$ conversion at $320^{\circ} \mathrm{C}$, decreasing at higher temperature. The experimental ethylene conversion was close to equilibrium for all temperatures. 
Experimental selectivity to ethylbenzene increased with temperature from $89 \%$ at $320^{\circ} \mathrm{C}$ to $95 \%$ at $400^{\circ} \mathrm{C}$. Equilibrium selectivity is approximately $97 \%$, independent of temperature. The experimental results indicate a lower selectivity at lower temperature, resulting in a maximum experimental yield of $\mathrm{EB}$ at $360^{\circ} \mathrm{C}$. Below $360^{\circ} \mathrm{C}$ the yield is limited because of lower selectivity while above $360^{\circ} \mathrm{C}$ conversion of ethylene is limited by thermodynamic constraints.

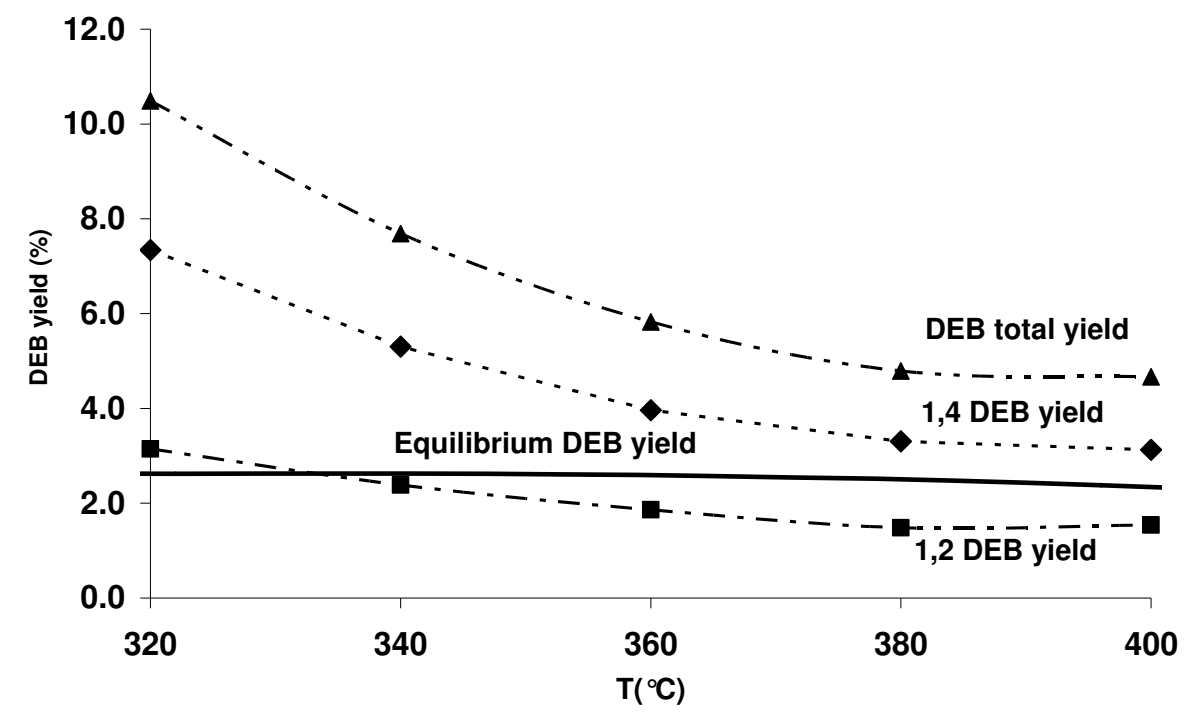

Figure 5.2: Equilibrium diethylbenzene yield in benzene alkylation as a function of temperature, total experimental DEB yield ( $\triangle$ ), experimental 1,4 DEB yield ( $\downarrow)$ and experimental 1,2 DEB yield (๘).

The experimental and equilibrium selectivity to diethylbenzene are shown in Figure 5.2. Other side products like tri-alkylated benzene could not be detected with mass spectrometry. Experimentally a DEB yield of slightly more than $10 \%$ was found at $320^{\circ} \mathrm{C}$. With increasing temperature the yield of DEB reduced to $5 \%$. The thermodynamic equilibrium predicts a constant DEB yield of just under 3\%, which is clearly lower than the experimental results. The ratio between the yields of 1,4 DEB and 1,2 DEB varied experimentally between 0.65:0.35 and 0.7:0.3, in reasonable agreement with thermodynamic calculations, resulting in a 0.6:0.4 ratio (not shown).

\subsubsection{Stability}

Figure 5.3 shows the results of stability tests for alkylation of benzene with ethylene at $340^{\circ} \mathrm{C}, 360^{\circ} \mathrm{C}$ and $400^{\circ} \mathrm{C}$. The conditions were identical to the experiment shown in Figure 5.1. All initial conversions were close to equilibrium, $98 \%\left(340^{\circ} \mathrm{C}\right), 97 \%$ 
$\left(360^{\circ} \mathrm{C}\right)$ and $91 \%\left(400^{\circ} \mathrm{C}\right)$ respectively. Conversion decreased with time on stream, observing the most pronounced deactivation at $400^{\circ} \mathrm{C}$ : conversion decreased to $75 \%$ after 20 hours at $400^{\circ} \mathrm{C}$. It should be noted that selectivity to ethylbenzene remained unchanged at $95 \%$ during deactivation of the catalyst (not shown). At 340 and $360^{\circ} \mathrm{C}$ more stable conversions were observed. The highest stability was found at $360^{\circ} \mathrm{C}$ : conversion only decreases from 96 to $94 \%$ in 20 hours.

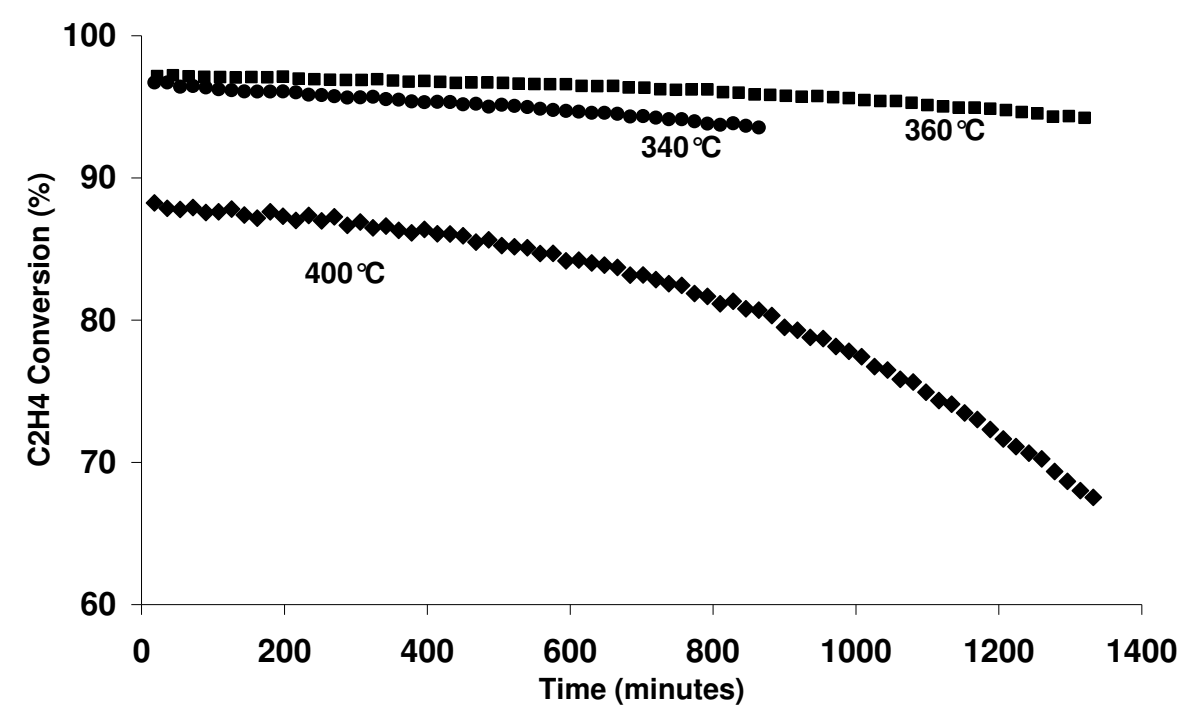

Figure 5.3: Stability of ethylene conversion in benzene alkylation at $340^{\circ} \mathrm{C}(\bullet), 360^{\circ} \mathrm{C}(\bullet)$, and $400^{\circ} \mathrm{C}(\diamond)$. Feed composition 30vol.\% $\mathrm{C}_{6} \mathrm{H}_{6}, 4.3 \mathrm{vol} . \% \mathrm{C}_{2} \mathrm{H}_{4}, 3 \mathrm{vol} . \% \mathrm{C}_{2} \mathrm{H}_{6}$ and $5 \mathrm{vol} . \% \mathrm{CH}_{4}$ in $\mathrm{Ar}$ (total flow rate $70 \mathrm{ml} \cdot \mathrm{min}^{-1}$ ).

The best stability (Figure 5.3) and the maximum yield (Figure 5.1) were both found at $360^{\circ} \mathrm{C}$ and therefore this temperature was selected for further stability tests under addition of $\mathrm{CO}, \mathrm{CO}_{2}$ and water (by-products of oxidative coupling) in the next paragraph.

\subsubsection{Effect of by-products of oxidative coupling at $360^{\circ} \mathrm{C}$}

Figure 5.4 shows the relative conversion (measured conversion divided by initial conversion) of ethylene in 4 separate experiments at $360^{\circ} \mathrm{C}$. The solid line in Figure 5.4 represents relative stability in the basic experiment at $360^{\circ} \mathrm{C}$ without any $\mathrm{H}_{2} \mathrm{O}, \mathrm{CO}$ or $\mathrm{CO}_{2}$. Water, $\mathrm{CO}$ and $\mathrm{CO}_{2}$ were added separately to check effects on catalyst stability and conversion. 


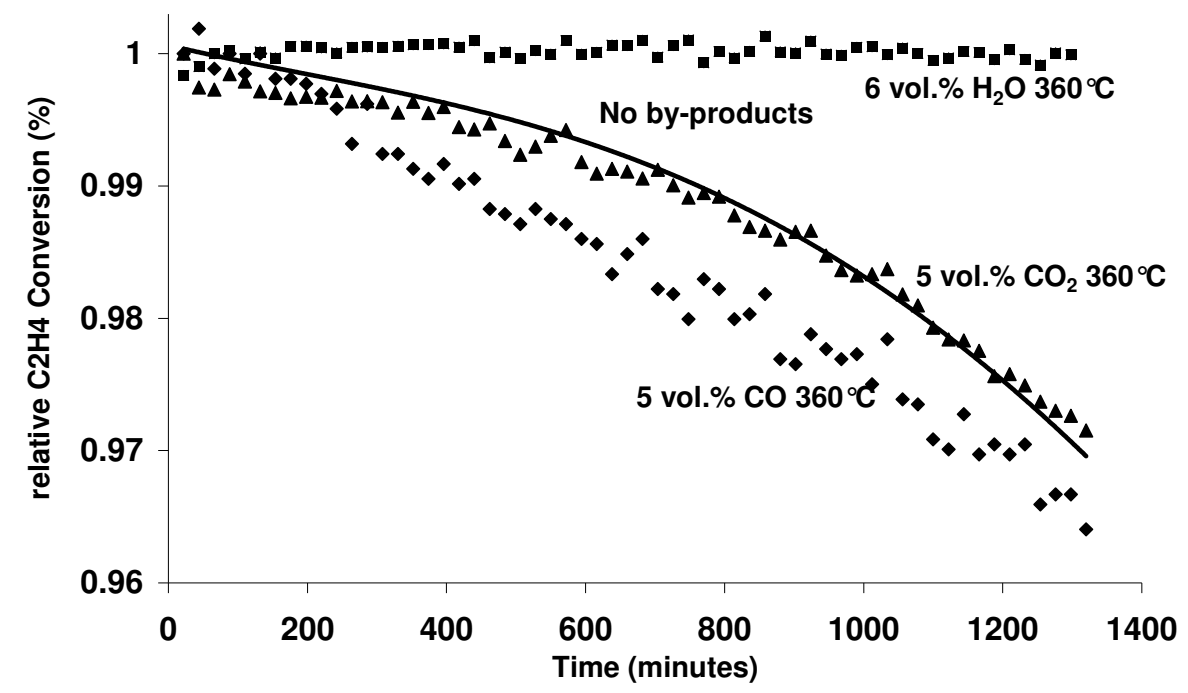

Figure 5.4: Stability of ethylene conversion in benzene alkylation at $360^{\circ} \mathrm{C}$ without adding by products (solid line) compared to stability in case of addition of $6 \mathrm{vol.} \% \mathrm{H}_{2} \mathrm{O}(-), 5$ vol.\% $\mathrm{CO}_{2}$ ( $\triangle$ ) or 5 vol.\% CO (४), respectively. Feed composition: 30vol.\% $\mathrm{C}_{6} \mathrm{H}_{6}, 4.3 \mathrm{vol} . \% \mathrm{C}_{2} \mathrm{H}_{4}, 3$ vol.\% $\mathrm{C}_{2} \mathrm{H}_{6}$ and 5 vol. $\% \mathrm{CH}_{4}$ in Ar, total flow rate $70 \mathrm{ml}^{.} \mathrm{min}^{-1}$

None of these additional reactants was converted. The initial ethylene conversion was about $98 \%$ (water), $97 \%\left(\mathrm{CO}_{2}\right.$ and basic experiment) and 95\% (CO), respectively. No significant effect of $5 \mathrm{vol} . \% \mathrm{CO}_{2}$ and only a small negative effect of $5 \mathrm{vol} . \% \mathrm{CO}$ on stability was observed: in both cases stability was comparable to the experiment at $360^{\circ} \mathrm{C}$ without addition of oxidative coupling products. Addition of water had a highly positive effect on stability, showing no deactivation during in 1400 minutes.

A gas mixture containing 4vol.\% $\mathrm{C}_{2} \mathrm{H}_{4}, 3$ vol. $\% \mathrm{C}_{2} \mathrm{H}_{6}, 5$ vol\% $\mathrm{CH}_{4}, 30$ vol.\% $\mathrm{C}_{6} \mathrm{H}_{6}$, $5 \mathrm{vol} . \% \mathrm{CO}, 5 \mathrm{vol} . \% \mathrm{CO}_{2}, 6 \mathrm{vol} . \% \mathrm{H}_{2} \mathrm{O}$ in $\mathrm{Ar}$ was fed to simulate benzene alkylation in the effluent stream of oxidative coupling. Conversion of ethylene, EB selectivity and EB yield as a function of temperature are compared in Figure 5.5. Thermodynamic equilibrium was calculated assuming that $\mathrm{CO}, \mathrm{CO}_{2}$ and water behave inert. 


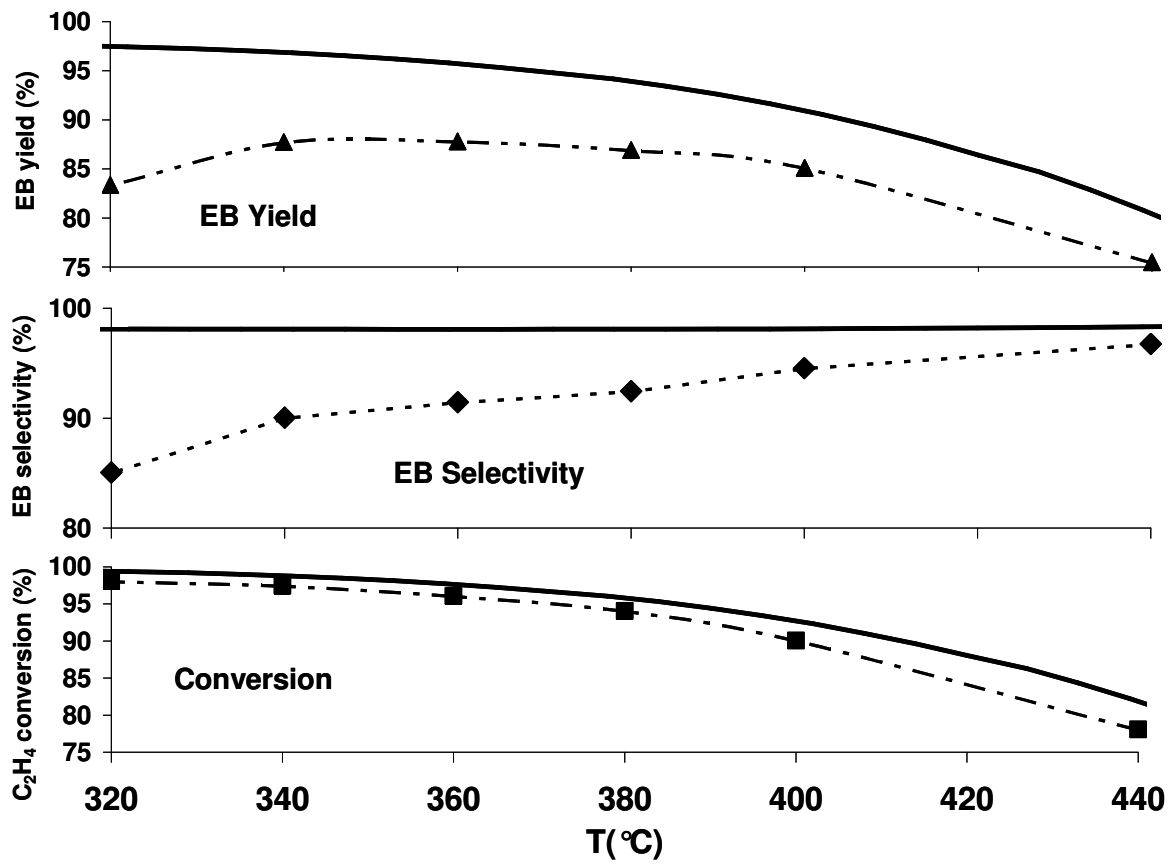

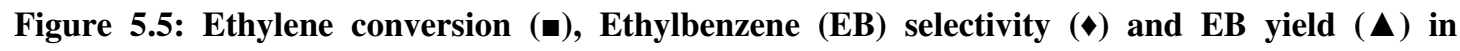
alkylation of benzene in mixture containing 5vol.\% $\mathrm{CO}, 5 \mathrm{vol} . \% \mathrm{CO}_{2}$ and 6 vol.\% $\mathrm{H}_{2} \mathrm{O}$ as a function of temperature, compared to thermodynamic equilibrium (solid lines)

Conversion is close to equilibrium under all conditions and a decreased selectivity is found at low temperature. High ethylbenzene yield is possible between $340^{\circ} \mathrm{C}$ and $380^{\circ} \mathrm{C}$ in the complete mixture containing water, $\mathrm{CO}$ and $\mathrm{CO}_{2}$. The yield of DEB (not shown) did not differ significantly from the results in Figure 5.2. Above $400^{\circ} \mathrm{C}$, EB yield decreases because of thermodynamic constraints.

Stable operation was found at all temperatures tested; as an example the results of a duration test at $360^{\circ} \mathrm{C}$ are shown in Figure 5.6. Constant ethylene conversion of $96 \%$ was combined with more than $90 \%$ selectivity to EB. This leads to a stable EB yield of $88 \%$ during 20 hours. 


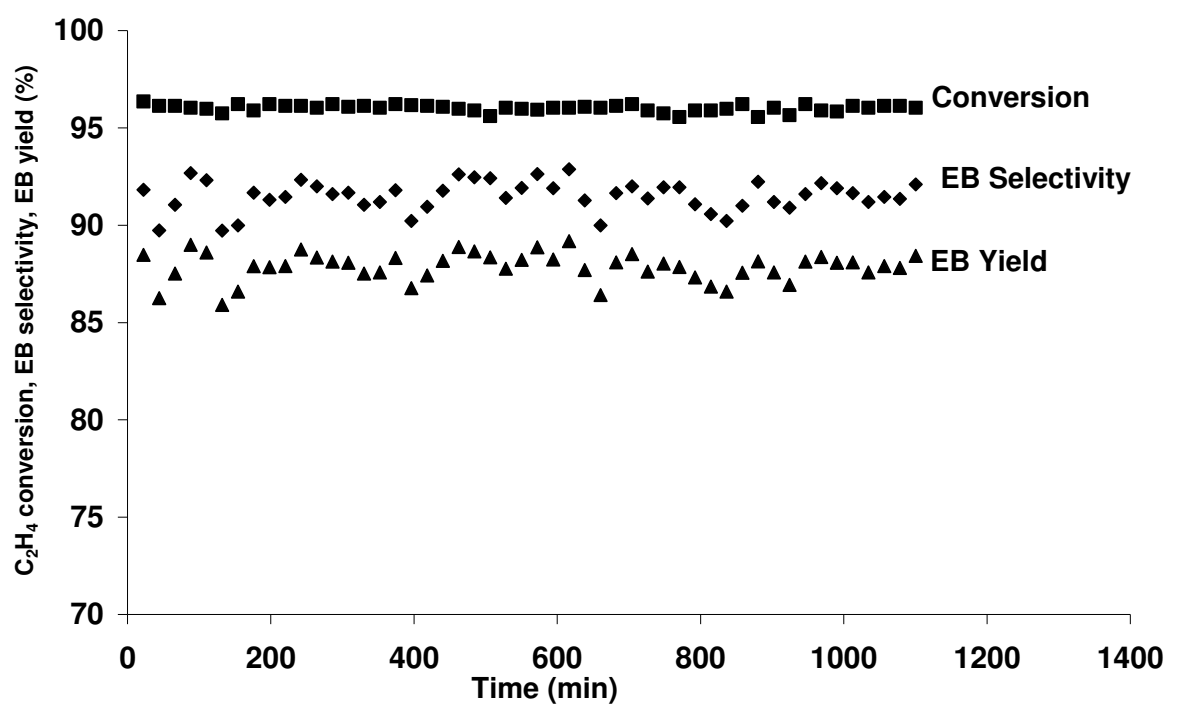

Figure 5.6: Stability of ethylene conversion (ø), Ethylbenzene (EB) selectivity (४) and EB yield $(\triangle)$ in alkylation of benzene as a function of temperature. Feed composition $4 \mathrm{vol} . \% \mathrm{C}_{2} \mathrm{H}_{4}$, 3vol.\% $\mathrm{C}_{2} \mathrm{H}_{6}, 5$ vol.\% $\mathrm{CH}_{4}, 30 v o l . \% \mathrm{C}_{6} \mathrm{H}_{6}, 5$ vol.\% $\mathrm{CO}, 5$ vol.\% $\mathrm{CO}_{2}, 6$ vol.\% $\mathrm{H}_{2} \mathrm{O}$ in Ar, flow rate $70 \mathrm{ml} / \mathrm{min}$ 


\subsection{Discussion}

\subsubsection{Conversion and selectivity}

Reaction of ethylene with benzene to ethylbenzene was investigated, with the intention to separate ethylene from the gas mixture produced in oxidative coupling. This gas mixture consists of $\mathrm{CH}_{4}, \mathrm{C}_{2} \mathrm{H}_{6}$ and $\mathrm{C}_{2} \mathrm{H}_{4}$, together with the side products of oxidative coupling $\mathrm{CO}_{2}, \mathrm{H}_{2} \mathrm{O}$ and $\mathrm{CO}$. In a first approach methane, ethane and ethylene were fed together with excess benzene over ZSM-5. Ethylene is the only reactive hydrocarbon, as no conversion of methane and ethane was detected. This was the case also in all other experiments shown, which means that the proposed concept is, in principle, suitable for reactive separation of ethylene from methane and ethane.

Figure 5.1 shows that ethylene conversion, ethylbenzene (EB) selectivity and ethylbenzene yield were close to thermodynamic equilibrium at $400^{\circ} \mathrm{C}$. Decreasing temperature led to increased ethylene conversion, in agreement with the estimation of the equilibrium based on thermodynamics (Figure 5.1). The selectivity to ethylbenzene decreased with decreasing temperature, in contrast with what was expected based on thermodynamics, predicting constant selectivity.

Thermodynamic calculations predict a constant DEB selectivity of $2.7 \%$ between 300 and $440^{\circ} \mathrm{C}$. However, the experimental yield of DEB was higher: $4.7 \%$ DEB yield was found at $400^{\circ} \mathrm{C}$ and increased further with decreasing temperature, reaching $10.5 \%$ at $320^{\circ} \mathrm{C}$ (Figure 5.2). Apparently, the conversions and product distribution are not determined by thermodynamics. Thus, the reactions are kinetically controlled according to Scheme 5.1 and selectivity is determined by the ratio of the rates of reactions 1 and 2 .

$$
\mathrm{B} \underset{1}{\stackrel{+\mathrm{E}}{\longrightarrow}} \mathrm{EB} \underset{2}{\stackrel{+\mathrm{E}}{\longrightarrow}} \mathrm{DEB}
$$

\section{Scheme 5.1: Schematic reaction pathway in alkylation of benzene}

As stated by Qi et al. [28], the primary product ethylbenzene is more reactive in alkylation than benzene and thus a high benzene to ethylene ratio is required to reach reasonable selectivity to EB. Our results described in this paper are in agreement with 
results of several other researchers $[17,20,25,30]$, who also reported higher DEB yields than predicted by thermodynamics. Selectivities of benzene ethylation obtained with different catalysts were compared in a review by Perego. In line with our results, selectivities to DEB of $8 \%$ were reported on zeolite $\mathrm{Y}$ and Beta, exceeding equilibrium yield to DEB by a factor 3. Christensen et al. [17] showed that use of a mesoporous ZSM-5 can enhance selectivity to EB and reduce DEB production, compared to conventional ZSM-5. In agreement with Scheme 5.1, this was explained by enhanced diffusion of EB out of the ZSM-5, resulting in lower concentration of EB in the zeolite pores and consequently less secondary alkylation than in normal ZSM-5.

\subsubsection{Catalyst deactivation \& effect of adding $\mathrm{CO}_{2}, \mathrm{H}_{2} \mathrm{O}$ and $\mathrm{CO}$}

The strongest deactivation of ZSM-5 was found at $400^{\circ} \mathrm{C}$ (Figure 5.3), while lower temperatures led to more stable operation. Regeneration with oxygen treatment was possible. Deactivation through coking on various zeolites has been widely studied and causes of deactivation are summarized in a review by Venuto [31]. Coking can range from simple olefin monomers chemisorbed at acid sites of the zeolite, to formation of highly aromatic hydrogen-deficient carbonaceous deposits. Both blocking of pores and deactivation of active sites were observed as cause of deactivation. It was found that deactivation of zeolites was most prominent at temperature above $375^{\circ} \mathrm{C}$, leading to aromatic carbon deposits. Small amounts of coke, mainly consisting of easily removable oligomeric products can be formed at temperatures around $300^{\circ} \mathrm{C}$ [31].

Experimentally, maximum yield and highest catalyst stability were observed at $360^{\circ} \mathrm{C}$ (Figures 5.1 and 5.4). This temperature was selected for addition of $\mathrm{CO}_{2}, \mathrm{CO}$ and $\mathrm{H}_{2} \mathrm{O} . \mathrm{CO}_{2}$ had no effect and $\mathrm{CO}$ had a slightly negative effect on catalyst stability. The decrease in conversion as a function of time is similar to the base case without any additions (Figure 5.4). Water clearly improves catalyst stability, as the conversion was constant throughout the 1200 minute experiment (Figure 5.4). It should be noted that the conversion of ethylene is close to equilibrium under these conditions, which may imply that only part of the catalyst bed contributes. This may hide any possible deactivation effect. However, deactivation was clearly observed, in absence of water (Figure 5.4), in contrast to the performance in presence of water (Figures 5.4 and 5.6). The stabilizing effect of water is also reported in steam reforming reactions [32] as well as dehydrogenation reactions, e.g. alkanes and ethylbenzene to styrene [33]. The 
increased stability of the catalysts was ascribed to coke gasification by steam, avoiding accumulation of carbon deposits.

Comparison of Figure 5.5 and Figure 5.1 shows that the selectivity pattern of reactions is not influenced by addition of the by-products of oxidative coupling. High conversions of ethylene to ethylbenzene are possible and yield of ethylbenzene is not affected by the addition of $\mathrm{CO}, \mathrm{CO}_{2}$ and $\mathrm{H}_{2} \mathrm{O}$.

Increasing the temperature to conditions closer to oxidative coupling operating conditions is unfortunately not feasible. When temperature is increased to above $400^{\circ} \mathrm{C}$, conversion of ethylene reduces due to thermodynamic limitations (Figure 5.5). Optimum operating conditions were again found at $360^{\circ} \mathrm{C}$ with an EB-yield of $88 \%$. It can be concluded from this study, that reactive separation of ethylene to ethylbenzene after oxidative coupling is a promising option. Operation of the alkylation reaction at atmospheric pressure between $320^{\circ} \mathrm{C}$ and $400^{\circ} \mathrm{C}$ was demonstrated and resulted in a high EB-yield. However, conditions as well as catalysts are not optimized here: increasing the pressure may further increase yield of EB [28].

\subsubsection{Process scheme}

A possible process scheme of oxidative coupling and reforming of methane combined with separation of ethylene via ethylbenzene production is shown in Figure 5.7. The exothermic oxidative coupling of methane takes place between $700^{\circ} \mathrm{C}$ and $800^{\circ} \mathrm{C}$ $\mathrm{C}_{2} \mathrm{H}_{4}$ and $\mathrm{C}_{2} \mathrm{H}_{6}$ are produced in this reaction (1). A high selectivity to ethylene is desired as ethane cannot react with benzene and is thus converted to synthesis gas in the reforming step (4). Distributed feeding of oxygen can be used in oxidative coupling to optimize ethylene yield $[9,10]$. Next to C2-products, the product mixture after oxidative coupling also contains remaining $\mathrm{CH}_{4}$ and byproducts $\mathrm{CO}, \mathrm{CO}_{2}, \mathrm{H}_{2} \mathrm{O}$ as well as small amounts of $\mathrm{H}_{2}$. Excess benzene is added to this stream, in order to react with ethylene to ethylbenzene at around $360^{\circ} \mathrm{C}(2)$. 


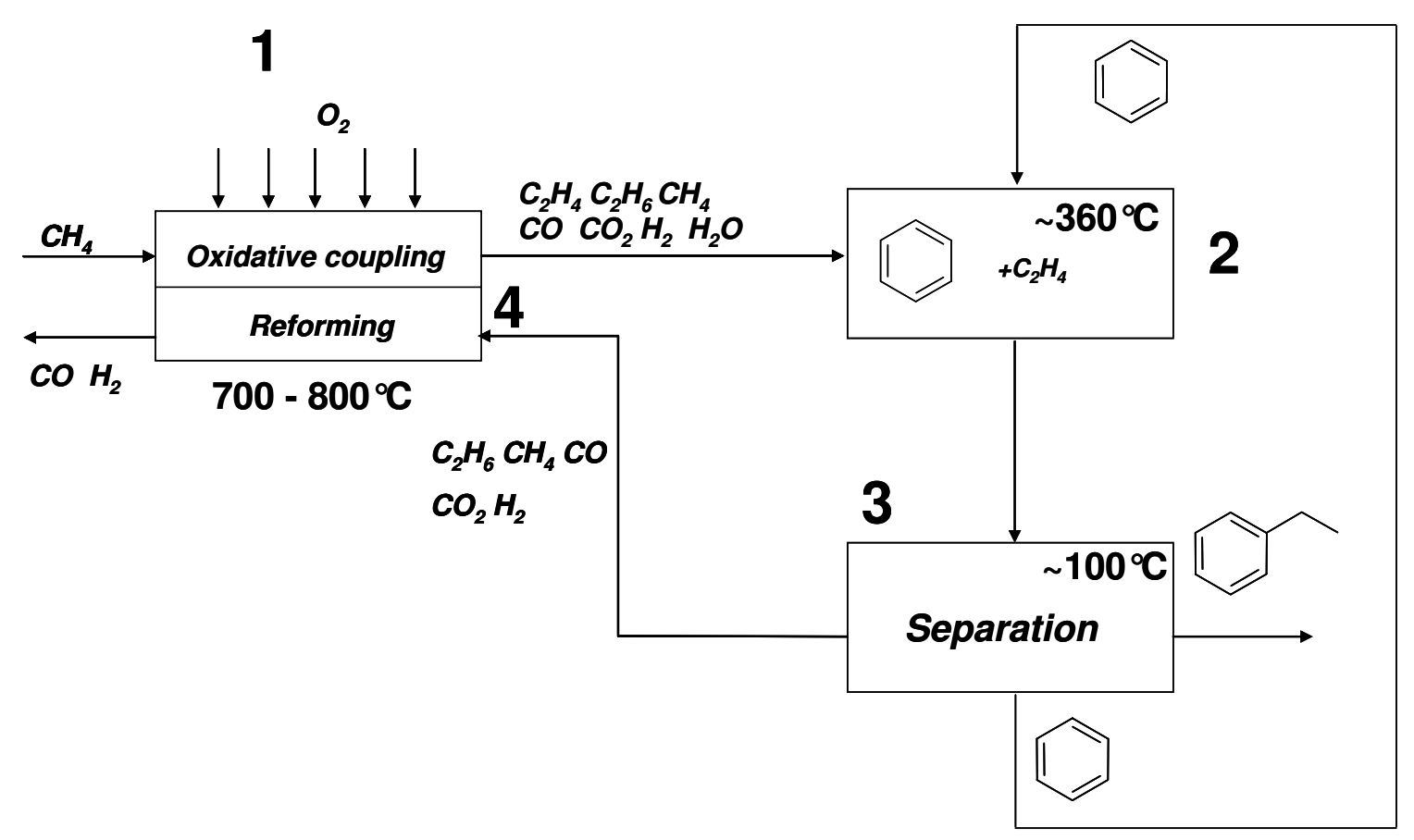

Figure 5.7: Possible process scheme of combined oxidative coupling and reforming of methane with ethylene reactive ethylene separation via alkylation of benzene

After alkylation, a separation step is required (3). The boiling points of ethylbenzene, benzene and di-ethylbenzene are $136^{\circ} \mathrm{C}, 80^{\circ} \mathrm{C}$ and $184^{\circ} \mathrm{C}$, respectively, which provides sufficient difference for separation via a distillation process of the several components, as described by Faessler [34]. The approximate temperature in the separation would be about $100^{\circ} \mathrm{C}$, depending on pressure. After separation, benzene has to be evaporated and heated to $360^{\circ} \mathrm{C}$, before recycling to reactor (2). The remaining stream is fed to the reforming reactor (4). Water is also removed during the separation step, so additional steam has to be added in the steam reforming reactor.

The oxidative coupling and reforming reactor are combined to use excess heat generated in the coupling process, to drive the endothermic steam reforming reaction. The total process will convert methane and oxygen to synthesis gas and ethylbenzene. Efficient heat exchange is needed to make this concept feasible. Another aspect to consider is the impact of the energy cost of benzene recycling and evaporation. 


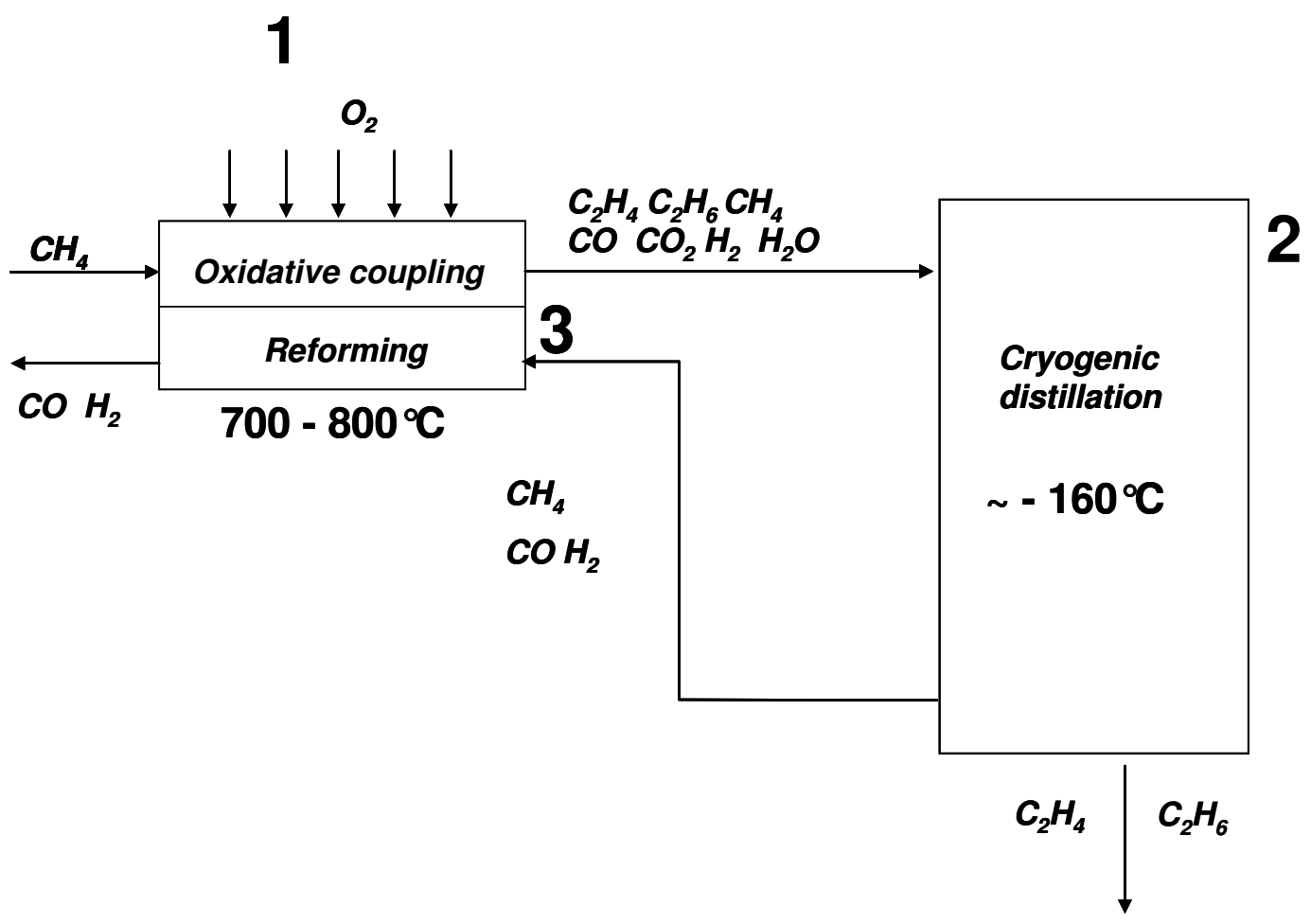

Figure 5.8: Possible process scheme of combined oxidative coupling and reforming of methane with included ethylene separation via cryogenic distillation

Figure 5.8 shows an alternative scheme with ethylene separation through cryogenic distillation (2) [13]. The oxidative coupling (1) and steam reforming part (3) of the process are identical to the scheme in Figure 5.7. The separation of ethylene needs rather extreme conditions, e.g. $-160^{\circ} \mathrm{C}$. With similar boiling points of ethane and ethylene, separation with cryogenic distillation is difficult and thus obtaining pure fractions of the desired product ethylene requires large and expensive columns. Parts of ethane and methane are lost during separation. This means additional loss of carbon source for production of synthesis gas in step 3. Also, water and $\mathrm{CO}_{2}$ have to be removed before distillation, implying additional equipment costs. A major issue is the huge temperature difference of around $900^{\circ} \mathrm{C}$ between step 1 and 2, leading to high cost for heat exchange equipment.

The essential advantage of reactive separation to ethylbenzene (Figure 5.7) is easier and more selective separation of ethylene compared to cryogenic distillation. Further, the temperature differences between reaction and separation could be reduced by 
$250^{\circ} \mathrm{C}$. In addition, the conversion of ethylene to the useful intermediate ethylbenzene is already included in the proposed scheme.

\subsection{Conclusions}

In a combined process of oxidative coupling and reforming of methane, reactive separation of ethylene via alkylation of benzene to ethylbenzene (EB) is a promising option to separate ethylene from the effluent gas of oxidative coupling. Ethylene was successfully converted to the useful chemical intermediate ethylbenzene using ZSM5. Yields of EB up to $90 \%$ were found at $95 \%$ conversion and $90 \%$ selectivity at $360^{\circ} \mathrm{C}$. None of the additional components present in the effluent gas of oxidative coupling $\left(\mathrm{CO}, \mathrm{CO}_{2}, \mathrm{CH}_{4}, \mathrm{C}_{2} \mathrm{H}_{6}\right.$ and $\left.\mathrm{H}_{2} \mathrm{O}\right)$ influences activity or selectivity of the alkylation catalyst. Stability of ZSM-5 is not influenced by the added components, with the exception of water, which even increases stability. It was concluded that reactive separation of ethylene to ethylbenzene is a promising option compared to cryogenic distillation, with the essential advantage of reduced temperature differences between oxidative coupling and ethylene separation. 


\subsection{References}

[1] V.R. Choudhary, B.S. Uphade, Catalysis Surveys from Asia 8 (2004) 15.

[2] M. Makri, C.G. Vayenas, Applied Catalysis A-General 244 (2003) 301.

[3] Istadi, N.A.S. Amin, Fuel 85 (2006) 577-592.

[4] N. Lapena-Rey, P.H. Middleton, Applied Catalysis A-General 240 (2003) 207.

[5] H. Zhang, J. Wu, B. Xu, C. Hu, Catalysis Letters 106 (2006) 161.

[6] J.A. Hugill, F.W.A. Tillemans, J.W. Dijkstra, S. Spoelstra, Applied Thermal Engineering 25 (2005) 1259.

[7] A. Machocki, A. Denis, Chemical Engineering Journal 90 (2002) 165.

[8] D. Czechowicz, K. Skutil, A. Torz, M. Taniewski, Journal of Chemical Technology and Biotechnology 79 (2004) 182.

[9] F.T. Akin, Y.S. Lin, Catalysis Letters 78 (2002) 239.

[10] F.T. Akin, Y.S. Lin, Aiche Journal 48 (2002) 2298.

[11] P.O. Graf, B.L. Mojet, L. Lefferts, Applied Catalysis A: General In Press, Accepted Manuscript.

[12] P.O. Graf, B.L. Mojet, J.G. van Ommen, L. Lefferts, Applied Catalysis A: General 332 (2007) 310-317.

[13] L. Mleczko, M. Baerns, Fuel Processing Technology 42 (1995) 217-248.

[14] S.N. Vereshchagin, V.K. Gupalov, L.N. Ansimov, N.A. Terekhin, L.A. Kovrigin, N.P. Kirik, E.V. Kondratenko, A.G. Anshits, Catalysis Today 42 (1998) 361-365.

[15] N.A.S. Amin, S.E. Pheng, Chemical Engineering Journal 116 (2006) 187-195.

[16] C.H. Christensen, K. Johannsen, E. Törnqvist, I. Schmidt, H. Topsøe, C.H. Christensen, Catalysis Today 128 (2007) 117-122.

[17] C.H. Christensen, K. Johannsen, I. Schmidt, C.H. Christensen, J. Am. Chem. Soc. 125 (2003) 13370-13371.

[18] J.L. Goncalves de Almeida, M. Dufaux, Y.B. Taarit, C. Naccache, Applied Catalysis A:General 114 (1994) 141-159.

[19] Y. Du, H. Wang, S. Chen, Journal of Molecular Catalysis A: Chemical 179 (2002) 253-261.

[20] X. Sun, Q. Wang, L. Xu, S. Liu, Catalysis Letters 94 (2004) 75-79.

[21] K.S.N. Reddy, B.S. Rao, V.P. Shiralkar, Applied Catalysis A:General 95 (1993) 53-63.

[22] M. Han, S. Lin, E. Roduner, Applied Catalysis A: General 243 (2003) 175-184.

[23] Y. Zhang, H. Xing, P. Yang, P. Wu, M. Jia, J. Sun, T. Wu, Reaction Kinetics and Catalysis Letters 90 (2007) 45-52.

[24] H. You, W. Long, Y. Pan, Petroleum Science and Technology 24 (2006) 10791088.

[25] C. Perego, P. Ingallina, Catalysis Today 73 (2002) 3-22.

[26] N.Y. Chen, W.E. Garwood, Catalysis Reviews - Science and Engineering 28 (1986) 185-264.

[27] X. Chen, S. Huang, D. Cao, W. Wang, Fluid Phase Equilibria 260 (2007) 146152.

[28] Z. Qi, R. Zhang, Industrial and Engineering Chemistry Research 43 (2004) 4105-4111.

[29] Y. Song, S. Liu, Q. Wang, L. Xu, Y. Zhai, Fuel Processing Technology 87 (2006) 297-302. 
[30] G. Bellussi, G. Pazzuconi, C. Perego, G. Girotti, G. Terzoni, Journal of Catalysis 157 (1995) 227-234.

[31] P.B. Venuto, Microporous Materials 2 (1994) 297-411.

[32] D.L. Trimm, Catalysis Today 37 (1997) 233.

[33] G.R. Meima, P.G. Menon, Applied Catalysis A: General 212 (2001) 239-245.

[34] P.W. Faessler, K. Kolmetz, W.K. Ng, K. Senthil, T.Y. Lim, DISTILLATION 2005 Spring AIChE Meeting (2005). 


\title{
Chapter
}

\section{New insights in the water gas shift mechanism on $\mathrm{PtZrO}_{2}$ : the role of hydroxyl groups elucidated}

\begin{abstract}
The reactivity of mono- and multi-coordinated hydroxyl groups on $\mathrm{Pt} / \mathrm{ZrO}_{2}$ with $\mathrm{CO}$ was investigated with in-situ Transmission FT-IR. It was found that monocoordinated hydroxyl groups on the $\mathrm{ZrO}_{2}$ support reacted with $\mathrm{CO}$ to formate. Multicoordinated hydroxyl groups were needed for formate decomposition, producing $\mathrm{H}_{2}$ and $\mathrm{CO}_{2}$, taking place exclusively in the presence of Pt. The observed differences in reactivity of different types of $\mathrm{OH}$ groups are relevant for the WGS mechanism, assuming that formate is a reactive intermediate under the conditions used in this study $\left(300-400^{\circ} \mathrm{C}\right)$. The fact that $\mathrm{Pt}$ is needed for decomposition of formate indicates that the reactivity of formate depends on the position on the $\mathrm{ZrO}_{2}$ surface, i.e. in close vicinity or remote from metal particles. Our results show that reduction of the support was limited to structural defective zirconia sites at edges and kinks, hosting the monocoordinated hydroxyl groups. These sites can be re-oxidized with water, reestablishing the hydroxyl groups.
\end{abstract}




\subsection{Introduction}

Environmental issues and the depletion of crude oil stimulate the search for alternative energy carriers. Hydrogen based fuel cells were widely investigated as replacement for conventional combustion engines and showed to be very promising [2-5]. The expected increase in hydrogen demand has led to extensive research to optimize hydrogen production. At the moment, natural gas is the biggest source for hydrogen. Synthesis gas $\left(\mathrm{CO}+\mathrm{H}_{2}\right)$ can be produced from natural gas via steam reforming, $\mathrm{CO}_{2}$ reforming, catalytic partial oxidation and auto thermal reforming. Steam methane reforming (SMR) is the most common process for hydrogen production (1):

$$
\mathrm{CH}_{4}+\mathrm{H}_{2} \mathrm{O} \longrightarrow 3 \mathrm{H}_{2}+\mathrm{CO} \quad\left(\Delta \mathrm{H}_{298}^{0}=206 \mathrm{~kJ} / \mathrm{mol}\right)
$$

Carbon monoxide is also formed in addition to hydrogen and the mixture is used directly in numerous industrial applications [6]. If direct use of the hydrogen is desired, $\mathrm{CO}$ has to be removed from the synthesis gas mixture. Water gas shift (WGS) (2) is an interesting reaction for reducing CO concentrations, additionally producing more $\mathrm{H}_{2}$. As fuel cell applications require $\mathrm{CO}$-free hydrogen, further purification by selective oxidation of $\mathrm{CO}$ or methanation is necessary after water gas shift reaction [7-9].

$$
\mathrm{CO}+\mathrm{H}_{2} \mathrm{O} \quad \rightleftarrows \quad \mathrm{H}_{2}+\mathrm{CO}_{2} \quad\left(\Delta \mathrm{H}^{0}{ }_{298}=-40.6 \mathrm{~kJ} / \mathrm{mol}\right)
$$

$\mathrm{PtZrO}_{2}$ was studied as a promising catalyst for water gas shift reaction $[1,10,11]$. The reaction mechanism on noble metals is generally considered bifunctional, with essential roles for both the active metal and the support [12-15]. It has been reported that $\mathrm{Pt}$ cannot activate water under water gas shift reaction conditions [16], and therefore activation of water has to take place on the support. Two mechanisms for WGS are indicated in literature: the formate associative mechanism [1, 17-19] and regenerative redox mechanism $[12,15,20]$. The regenerative redox mechanism requires a reducible support like $\mathrm{CeO}_{2}$ or $\mathrm{TiO}_{2}$.

A hydrid mechanism, so called "the associative mechanism with redox regeneration" was proposed for $\mathrm{PtZrO}_{2}$ [1]. In this mechanism, hydroxyls on the zirconia surface react with $\mathrm{CO}$ to form intermediate formate which can react/decompose into $\mathrm{H}_{2}$ and 
$\mathrm{CO}_{2}$. Afterwards the hydroxyl groups on zirconia are regenerated by water. Formate formation between $\mathrm{CO}$ and hydroxyl groups was also proposed earlier by $\mathrm{Ma}$ et al. [21]. Formate decomposition was suggested to be facilitated by water [10]. Azzam et al. [1] showed that $\mathrm{CO}_{2}$ and $\mathrm{H}_{2}$ could also be formed when $\mathrm{CO}$ was pulsed over $\mathrm{PtZrO}_{2}$ in the absence of water, using hydroxyl groups of the zirconia support and consequently removing oxygen from the zirconia support. Consequently the zirconia needs to be reactivated by decomposing water, thus filling the oxygen vacancy as well as generating $\mathrm{OH}$ groups. However, after regeneration of zirconia with $\mathrm{N}_{2} \mathrm{O}$ instead of $\mathrm{H}_{2} \mathrm{O}$, resulting in the absence of $\mathrm{OH}$-groups, $\mathrm{CO}$ is able to remove oxygen as well by forming $\mathrm{CO}_{2}$. This confirms the ability of zirconia to provide oxygen under WGS conditions $\left(300^{\circ} \mathrm{C}\right)$, even in absence of $\mathrm{OH}$ groups. However, clear evidence exists that the formate mechanism is not relevant for $\mathrm{Pt} / \mathrm{ZrO}_{2}$ when operating at mild temperature $\left(200^{\circ} \mathrm{C}\right)$, based on DRIFT experiments in combination with isotopic transient experiments by Tibiletti et al [11]. Nevertheless, the formate mechanism continues to be a valid hypothesis for higher temperatures of operation $\left(300-400^{\circ} \mathrm{C}\right)$.

Until now, the exact role of the hydroxyl groups in WGS has not been reported, while the presence of differently coordinated hydroxyl groups on the zirconia surface was already demonstrated with FT-IR in 1973 by Tsyganenko et al. [22]. In the following years, more studies were devoted to hydroxyl characterization on zirconia. Two different hydroxyl coordinations located at $3760 \mathrm{~cm}^{-1}$ and $3660 \mathrm{~cm}^{-1}$ in the FT-IR spectrum [23-26], respectively, were found on the surface of monoclinic zirconia. Mono-coordinated hydroxyls were assigned to IR signals at about $3760 \mathrm{~cm}^{-1}$ [26]. With increasing hydroxyl coordination number, the signal in FT-IR of the respective hydroxyl group shifts to lower wave number [22]. However, no consensus exists about the exact coordination of the hydroxyl peak located around $3660 \mathrm{~cm}^{-1}$. Quintard et al. [26] assigned this peak to bi-coordinated hydroxyl groups, while others assigned it to tri-coordinated hydroxyl groups [22, 27]. Korhonen et al. [28] concluded the presence of hydroxyl groups of mono, bi- and tri coordination on monoclinic zirconia from a combined study by DFT and FT-IR spectroscopy. In this study the more general term multi-coordinated hydroxyl groups will be used for the peak located around $3660 \mathrm{~cm}^{-1}$. 
In this article, we report the reactivity of differently coordinated hydroxyl groups with CO. In situ transmission FT-IR was used to characterize hydroxyl groups on both monoclinic $\mathrm{ZrO}_{2}$ and $\mathrm{Pt} / \mathrm{ZrO}_{2} . \mathrm{ZrO}_{2}$ supported catalysts were selected because of the relative simplicity, as compared to $\mathrm{TiO}_{2}$ and $\mathrm{CeO}_{2}$, of both the $\mathrm{OH}$ band region in the IR spectrum as well as minimal reducibility of the oxide. Additionally, the respective reactivity of the $\mathrm{OH}$ groups with $\mathrm{CO}$ was studied at different temperatures (240$\left.400^{\circ} \mathrm{C}\right)$. Gaseous product formation $\left(\mathrm{CO}_{2}\right.$ and $\left.\mathrm{H}_{2}\right)$ during exposure to $\mathrm{CO}$ was monitored in a micro reactor flow setup. The results provide mechanistic information on the water gas shift reaction on $\mathrm{Pt} / \mathrm{ZrO}_{2}$, under the assumption that the associative formate mechanism is operative under conditions used here, i.e. high temperature.

\subsection{Experimental}

Monoclinic $\mathrm{ZrO}_{2}$ obtained from Gimex Technical Ceramics (RC-100) was used as catalyst and as support for Pt. Zirconia, with particle sizes between 300 and $600 \mu \mathrm{m}$, was treated at $600^{\circ} \mathrm{C}$ for $24 \mathrm{~h}$ under a helium flow. The structure of the zirconia was not changed by this pre-treatment and remained monoclinic, as detected by XRD. 0.5 wt.\% $\mathrm{PtZrO}_{2}$ was prepared by wet impregnation of $10 \mathrm{~g}$ of $\mathrm{ZrO}_{2}$ with aqueous solution, obtained by dissolving $\mathrm{H}_{2} \mathrm{PtCl}_{6}$ (Alfa Aesar) in $25 \mathrm{ml}$ of water. $\mathrm{PtZrO}_{2}$ was calcined at $600^{\circ} \mathrm{C}$ in synthetic air $(30 \mathrm{ml} / \mathrm{min})$ for $24 \mathrm{~h}\left(\operatorname{ramp~} 5^{\circ} \mathrm{C} \mathrm{min}^{-1}\right)$.

Platinum loadings on zirconia and the exact composition of the zirconia support were determined using a Philips X-ray fluorescence spectrometer (PW 1480). Platinum dispersion was determined with pulse $\mathrm{H}_{2}$ chemisorption at room temperature on $0.3 \mathrm{~g}$ of catalyst using a Micromeritics Chemisorb 2750, assuming a $\mathrm{H} / \mathrm{Pt}$ ratio of 1 . Before pulsing hydrogen, the catalyst was reduced in $\mathrm{H}_{2}$ at $400^{\circ} \mathrm{C}$ for 15 minutes and cooled in He to room temperature subsequently.

The transmission FT-IR measurements were recorded with a Bruker Vector 22 with MCT detector. A self supporting wafer was pressed of $15 \mathrm{mg}$ of the sample and placed into a home made gold coated cell. Before measurements the samples were reduced in 5 vol.\% $\mathrm{H}_{2}$ for 30 minutes (Linde Gas 5.0) at $400^{\circ} \mathrm{C}$ (heating rate $10^{\circ} \mathrm{C} / \mathrm{min}$, $40 \mathrm{ml} / \mathrm{min}$ ) and subsequently cooled to reaction temperature in He. 
$\mathrm{ZrO}_{2}$ was studied with FT-IR at $400^{\circ} \mathrm{C}$ under $\mathrm{He}$ (Linde Gas 5.0) to investigate the different hydroxyl groups in the IR spectrum. Helium was dried with a Varian Chromopack CP17971 Gas Clean Moisture Filter. The resolution was $4 \mathrm{~cm}^{-1}$ and 256 scans were taken. The reactivity of hydroxyl groups on $\mathrm{ZrO}_{2}$ and $\mathrm{PtZrO}_{2}$ towards $\mathrm{CO}$ was investigated by subjecting the catalysts to different $\mathrm{CO}$ (Hoekloos 4.7) concentrations in $\mathrm{He}$ (total flow $40 \mathrm{ml} / \mathrm{min}$ ). No water was present during these experiments.

A micro reactor flow setup was used in combination with a Balzers QMS $200 \mathrm{~F}$ mass spectrometer to study transient gaseous product formation during exposure to $\mathrm{CO}$ at different temperatures. The IR measurements were mimicked in the flow setup, as gas phase products in IR were not detectable because of too low concentrations. A detailed description of the micro reactor flow setup is given in an earlier publication [29]. About $250 \mathrm{mg}$ of $0.5 \mathrm{wt} . \% \mathrm{PtZrO}_{2}(0.3-0.6 \mathrm{~mm})$ was inserted in a quartz micro reactor with inner and outer diameter of respectively 4 and $6 \mathrm{~mm}$, reduced with $5 \mathrm{vol} . \%$ $\mathrm{H}_{2}$ in Ar for 15 minutes at $400^{\circ} \mathrm{C}\left(\left(\right.\right.$ heating rate $\left.10^{\circ} \mathrm{C} / \mathrm{min}, 100 \mathrm{ml} / \mathrm{min}\right)$ and flushed with Ar subsequently. $\mathrm{CO}$ (concentration: 8vol.\% ) in $\operatorname{Ar}(100 \mathrm{ml} / \mathrm{min}$ ) was fed to the reactor at different temperatures $\left(240^{\circ} \mathrm{C}, 300^{\circ} \mathrm{C}\right.$ and $\left.400^{\circ} \mathrm{C}\right)$ and formation of gaseous products (i.e. $\mathrm{CO}_{2}$ and $\mathrm{H}_{2}$ ) was measured with $\mathrm{MS}$ detecting $\mathrm{M} / \mathrm{z}=44$ and $\mathrm{M} / \mathrm{z}=2$. The catalyst was treated with $6 \mathrm{vol} . \%$ of water in Ar between experiments to regenerate hydroxyl groups. 


\subsection{Results}

\subsubsection{Characterization}

The composition of the zirconia as determined with XRF is given in Table 6.1. The Pt content of $\mathrm{PtZrO}_{2}$ was $0.58 \pm 0.01$ wt.\%. Pt dispersion was $50 \%$ as determined with $\mathrm{H}_{2}$ chemisorption, assuming a $\mathrm{H} / \mathrm{Pt}$ ratio of 1 .

Table 6.1: Catalyst composition

\begin{tabular}{|c|c|}
\hline Zirconia Composition & Weight \% \\
\hline $\mathrm{ZrO}_{2}$ & 98.1 \\
\hline $\mathrm{HfO}_{2}$ & 1.7 \\
\hline $\mathrm{TiO}_{2}$ & 0.1 \\
\hline $\mathrm{Y}_{2} \mathrm{O}_{3}$ & 0.1 \\
\hline $\mathrm{Pt}$ content $\mathrm{PtZrO}_{2}$ & 0.58 \\
\hline
\end{tabular}

Hydroxyl groups on $\mathrm{ZrO}_{2}$ and $\mathrm{PtZrO}_{2}$ were studied under helium with Transmission FT-IR. Figure 6.1 shows the hydroxyl region $\left(3900-3500 \mathrm{~cm}^{-1}\right)$ of the spectra obtained at $240^{\circ} \mathrm{C}, 300^{\circ} \mathrm{C}$ and $400^{\circ} \mathrm{C}$. Multiple peaks are found in the region between $3800 \mathrm{~cm}^{-1}$ and $3600 \mathrm{~cm}^{-1}$ with maxima at about $3745 \mathrm{~cm}^{-1}$ and $3658 \mathrm{~cm}^{-1}$. Peaks in the $3800-3700 \mathrm{~cm}^{-1}$ region can be assigned to mono-coordinated hydroxyl groups, while the $3700-3600 \mathrm{~cm}^{-1}$ can be assigned to multi-coordinated hydroxyl groups [22]. Multiple smaller peaks are observed in addition to the maxima in both regions indicating hydroxyl groups with different interactions with zirconia. Stabilization of hydroxyl groups by hydrogen interactions between neighbouring hydroxyl groups can induce a small shift to lower wavelengths, explaining the occurrence of multiple peaks [30].

Higher intensity of mono hydroxyls around $3760 \mathrm{~cm}^{-1}$ was found on $\mathrm{PtZrO}_{2}$ as compared to $\mathrm{ZrO}_{2}$ at $240^{\circ} \mathrm{C}$. The intensities of mono hydroxyl groups on both materials are similar at $300^{\circ} \mathrm{C}$ and $400^{\circ} \mathrm{C}$ and are hardly affected by temperature increase above $300^{\circ} \mathrm{C}$. In contrast, the intensity of multi-coordinated hydroxyl groups clearly decreases with increasing temperature on both $\mathrm{ZrO}_{2}$ and $\mathrm{PtZrO}_{2}$. The multicoordinated hydroxyls show similar intensities under all conditions on both. In general, the intensities of the hydroxyl groups on $\mathrm{ZrO}_{2}$ and $\mathrm{PtZrO}_{2}$ are quite similar. 

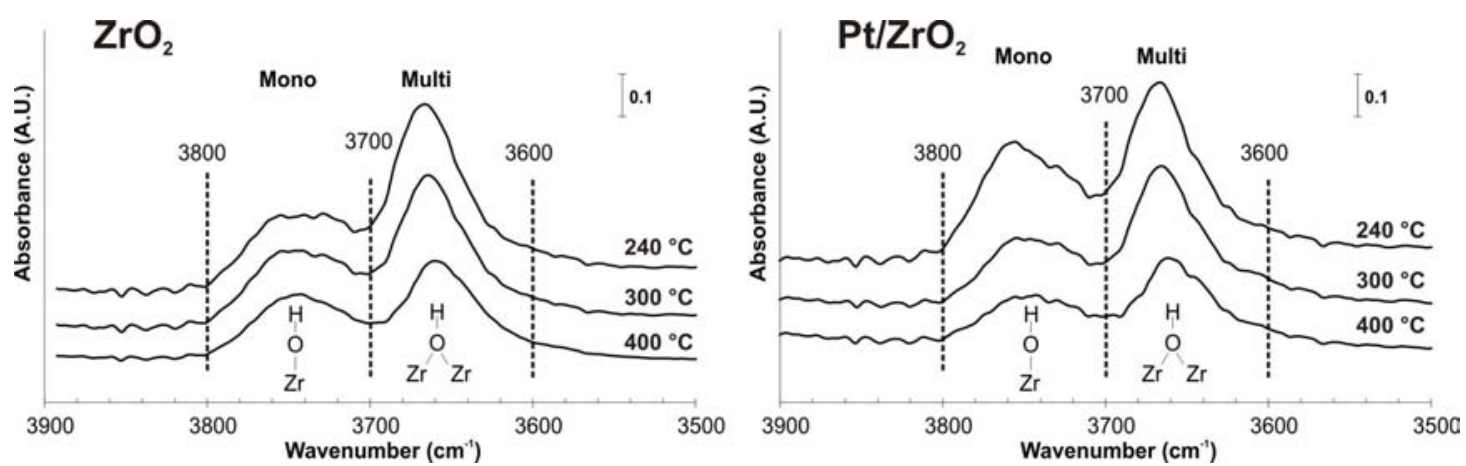

Figure 6.1: IR spectrum of $\mathrm{ZrO}_{2}$ (left) and $\mathrm{PtZrO}_{2}$ (right) at $400^{\circ} \mathrm{C}$ under $\mathrm{He}$

\subsubsection{Reactivity of hydroxyl groups with $\mathrm{CO}$ on $\mathrm{ZrO}_{2}$}

Figure 6.2 shows close up spectra of the hydroxyl region $\left(3900-3500 \mathrm{~cm}^{-1}\right)$ and $\mathrm{C}-\mathrm{H}$ and $\mathrm{O}-\mathrm{C}=\mathrm{O}$ formate regions $\left(3000-2850 \mathrm{~cm}^{-1}\right) /\left(1700-1200 \mathrm{~cm}^{-1}\right)$ when $\mathrm{ZrO} 2$ was subjected to $\mathrm{CO}$ at $400^{\circ} \mathrm{C}$. The dotted lines represent the spectrum under helium, used as a reference. Addition of $\mathrm{CO}$ resulted in a decrease of the intensity of monocoordinated hydroxyl peak $\left(3800-3700 \mathrm{~cm}^{-1}\right)$, while the multi-coordinated hydroxyl peak (3700-3600 $\mathrm{cm}^{-1}$ region) was hardly influenced.
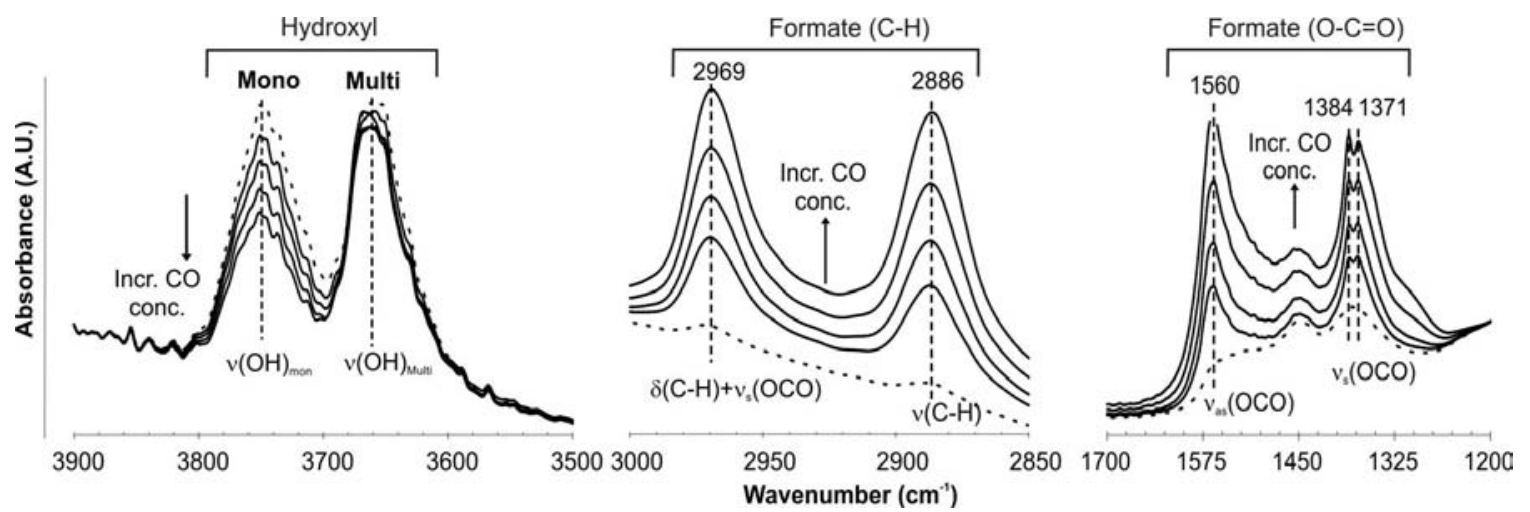

Figure 6.2: FT-IR spectra of addition of $\mathrm{CO}$ concentrations of $0,8,15,37,65 \mathrm{vol} . \%$ on $\mathrm{ZrO}_{2}$ at $400^{\circ} \mathrm{C}$. Hydroxyl region $\left(3900-3500 \mathrm{~cm}^{-1}\right)$, formate region $\left(3000-2850 \mathrm{~cm}^{-1}\right)$ and $\left(1700-1200 \mathrm{~cm}^{-1}\right)$. Reference spectrum taken in He (dotted line).

As a result of $\mathrm{CO}$ addition new peaks appeared on $\mathrm{ZrO}_{2}$ at $2969 \mathrm{~cm}^{-1}, 2886 \mathrm{~cm}^{-1}$, $1560 \mathrm{~cm}^{-1}, 1384 \mathrm{~cm}^{-1}$ and $1371 \mathrm{~cm}^{-1}$. The peaks in the $3000-2850 \mathrm{~cm}^{-1}$ and $1700-1200 \mathrm{~cm}^{-1}$ region can be assigned to $\mathrm{C}-\mathrm{H}$ bending and $\mathrm{O}-\mathrm{C}=\mathrm{O}$ stretching vibrations respectively and are representing surface formate [10]. 
Figure 6.3 shows the integrated intensities of FT-IR signals of the mono-coordinated and the formate representing $\mathrm{C}-\mathrm{H}$ region $\left(3000-2850 \mathrm{~cm}^{-1}\right)$ as a function of $\mathrm{CO}$ concentration. It is shown that the intensity of the formate peak increased steadily with increasing $\mathrm{CO}$ concentration, accompanied by increased consumption of monocoordinated hydroxyl groups. The experiments presented here were mimicked experimentally in the micro reactor flow setup to check the formate decomposition to $\mathrm{CO}_{2}$ and $\mathrm{H}_{2}$. However, no gas phase products were detected with mass spectrometry when exposing $\mathrm{ZrO}_{2}$ to $\mathrm{CO}$ between $240^{\circ} \mathrm{C}$ and $400^{\circ} \mathrm{C}$.

It was found that formate formation was completely reversible: reducing $\mathrm{CO}$ concentration led to a decrease of surface formate and a simultaneous increase of mono-coordinated hydroxyl groups. Complete removal of $\mathrm{CO}$ led to the disappearance of surface formate and complete recovery of mono-coordinated hydroxyl groups (not shown).

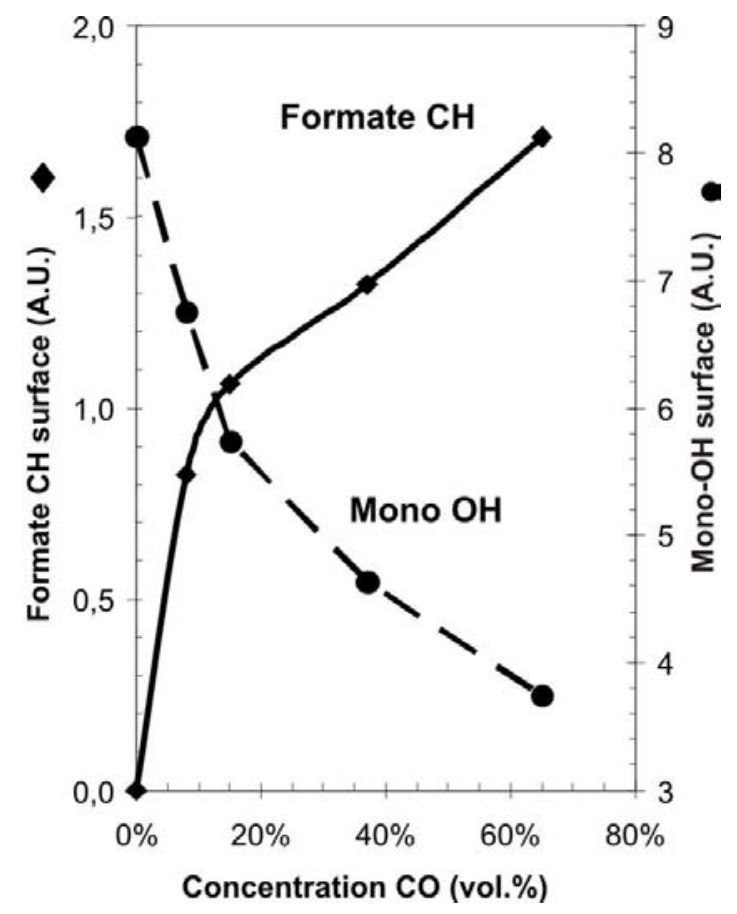

Figure 6.3: Integrated FT-IR regions of mono-coordinated hydroxyls $(\bullet)\left(3745 \mathrm{~cm}^{-1}\right)$ and formate $(\diamond)\left(2886 \mathrm{~cm}^{-1}\right)$ as a function of $\mathrm{CO}$ concentration at $400^{\circ} \mathrm{C}$.

The effect of temperature to formate formation on zirconia is shown in Figure 6.4, showing the FT-IR spectra of $\mathrm{ZrO}_{2}$ of the hydroxyl region $\left(3850-3550 \mathrm{~cm}^{-1}\right)$ and formate region $\left(3025-2825 \mathrm{~cm}^{-1} / 1750-1150 \mathrm{~cm}^{-1}\right)$ at $240^{\circ} \mathrm{C}, 300^{\circ} \mathrm{C}$ and $400^{\circ} \mathrm{C}$ after 
exposure to $8 \mathrm{vol} . \% \mathrm{CO}$ (solid line). Temperature was increased under continuous presences of $\mathrm{CO}$. The dashed lines in Figure 6.4 represent the spectra under He at the respective temperature (as shown in Figure 6.1). Two well defined hydroxyl peaks were observed at $240^{\circ} \mathrm{C}$ under helium (dashed) with maxima around $3745 \mathrm{~cm}^{-1}$ (monocoordinated hydroxyls) and $3658 \mathrm{~cm}^{-1}$ (multi-coordinated hydroxyls). The monocoordinated hydroxyl peak $\left(3745 \mathrm{~cm}^{-1}\right)$ at $240^{\circ} \mathrm{C}$ decreased instantaneously when $\mathrm{ZrO}_{2}$ was treated with 8vol.\% CO (Figure 6.4A-I solid line). Simultaneously, large quantities of formate were formed (Figure 6.4B-I and 4C-I, solid line).

The amount of adsorbed formate decreased when the temperature was increased to $300^{\circ} \mathrm{C}$ (Figures 6.4B-II and 6.4C-II, solid line) and mono-coordinated hydroxyls $\left(3700-3800 \mathrm{~cm}^{-1}\right)$ partly recovered (Figure 6.4A-II, solid line). Further increase of temperature to $400^{\circ} \mathrm{C}$ caused the amount of formate to decrease even more (Figures 6.4B-III and 6.4C-III, solid line). Simultaneously, the intensity of monocoordinated hydroxyl groups increased further, becoming similar to the level obtained in helium at $400^{\circ} \mathrm{C}$ in the absence of $\mathrm{CO}$ (Figure 6.4A-III, solid line).
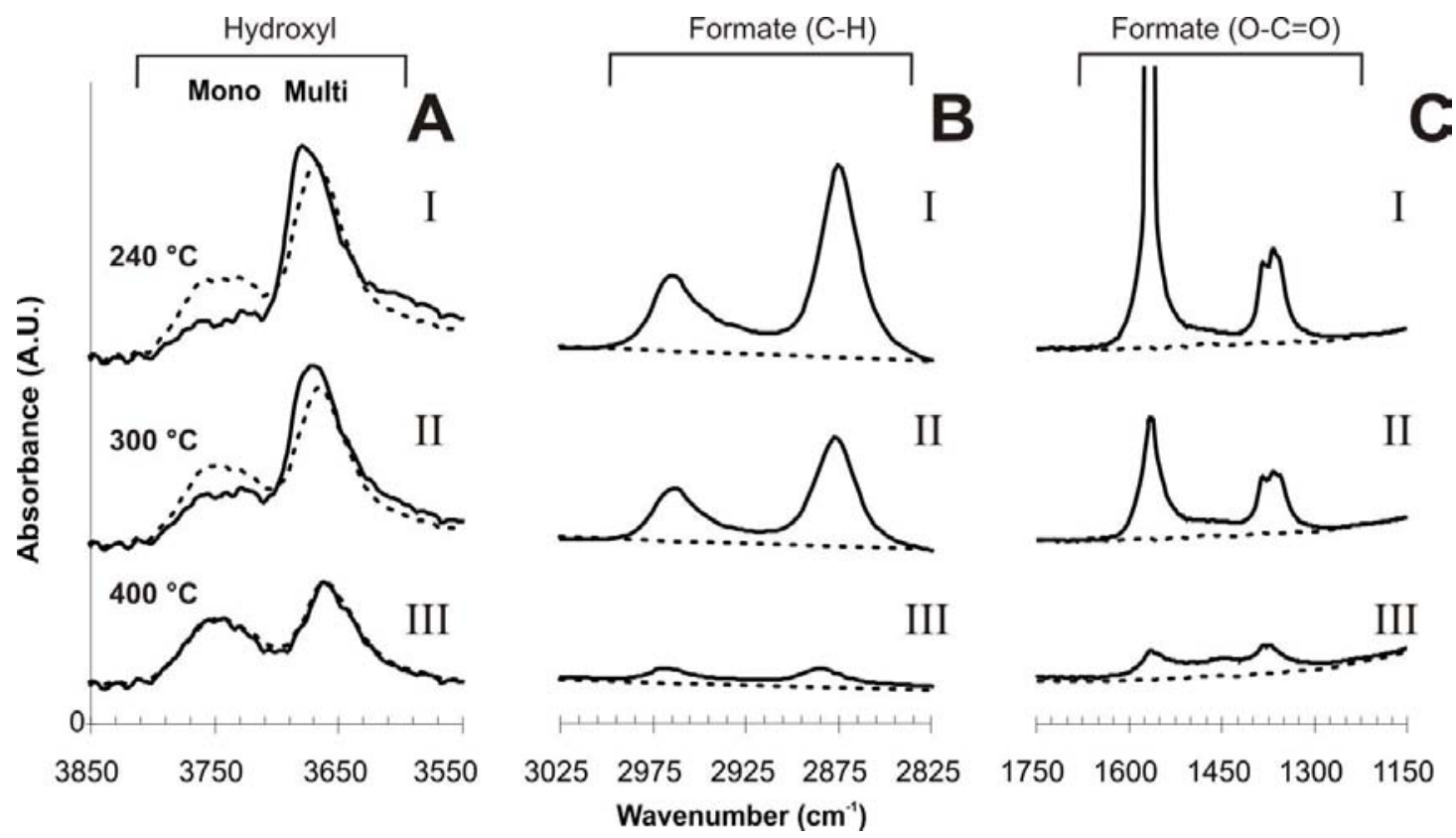

Figure 6.4: FT-IR spectra of $\mathrm{ZrO}_{2}$ subjected to 8vol.\% $\mathrm{CO}$ (solid lines) at $240^{\circ} \mathrm{C}$ (I), $300^{\circ} \mathrm{C}$ (II) and $400^{\circ} \mathrm{C}$ (III). Hydroxyl region $\left(3850-3550 \mathrm{~cm}^{-1}\right)(\mathrm{A})$, Formate region $\left(\mathrm{C}-\mathrm{H} 3025-2825 \mathrm{~cm}^{-1}\right.$ (C), $O-C=O$ 1750-1150 $\left.\mathrm{cm}^{-1}(C)\right)$. Reference spectra under helium (dashed lines) 
The intensities of multi-coordinated hydroxyl groups did not change as a result of CO addition during the experiments on $\mathrm{ZrO}_{2}$, as similar intensities of multi $\mathrm{OH}$ groups were found in presence and absence of $\mathrm{CO}$ between $240^{\circ} \mathrm{C}$ and $400^{\circ} \mathrm{C}$. No gaseous products were detected on $\mathrm{ZrO}_{2}$ between 240 and $400^{\circ} \mathrm{C}$ when this experiment was mimicked in experiments in the micro reactor flow setup.

\subsubsection{Reactivity of hydroxyl groups with $\mathrm{CO}$ on $\mathrm{PtZrO}_{2}$}

Figure 6.5 shows Transmission FT-IR spectra, obtained by treating $\mathrm{PtZrO}_{2}$ with $8 \%$ $\mathrm{CO}$ (solid lines) at $240^{\circ} \mathrm{C}, 300^{\circ} \mathrm{C}$ and $400^{\circ} \mathrm{C}$, compared to reference spectra under helium (dashed lines, identical with results in Figure 6.1). Complete consumption of mono-coordinated hydroxyls was observed at $240^{\circ} \mathrm{C}$ (Figure 6.5A-I, solid line). Only marginal changes in the amount of multi-coordinated hydroxyls were observed at $240^{\circ}$ C. Simultaneously, formate was formed (Figures 6.5B-I and 6.5C-I, solid line). The formate formation is still reversible: removal of CO leads to disappearance of formate species (not shown). A decrease of multi-coordinated hydroxyls was observed when the temperature was increased to $300^{\circ} \mathrm{C}$. Also, the amount of formate on $\mathrm{PtZrO}_{2}$ decreased as compared to the amount of formate observed at $240^{\circ} \mathrm{C}$.

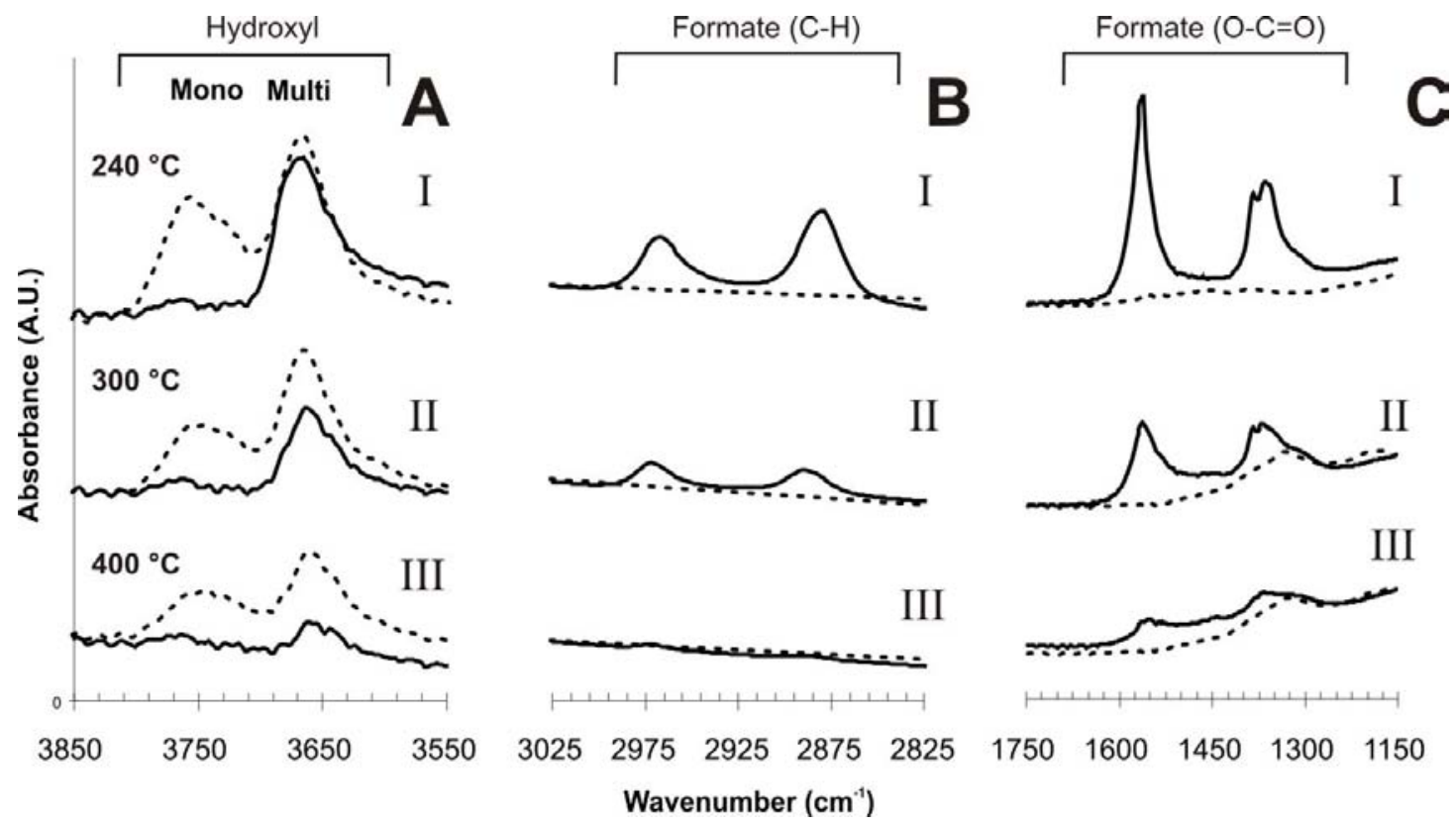

Figure 6.5: FT-IR spectra of $0.5 w \mathrm{wt} \% \mathrm{PtZrO}_{2}$ subjected to $8 \% \mathrm{CO}$ (solid lines) at $240^{\circ} \mathrm{C}(\mathrm{I}), 300^{\circ} \mathrm{C}$ (II) and $400^{\circ} \mathrm{C}$ (III). Hydroxyl region $\left(3850-3550 \mathrm{~cm}^{-1}\right)(\mathrm{A})$, Formate region $\left(\mathrm{C}-\mathrm{H} 3025-2825 \mathrm{~cm}^{-1}\right.$ (C), O-C =O 1750-1150 $\mathrm{cm}^{-1}(\mathrm{C})$ ). Reference spectra under helium (dashed lines). 
When temperature is increased to $400^{\circ} \mathrm{C}$, most multi-coordinated hydroxyls on $\mathrm{PtZrO}_{2}$ were consumed and formate almost disappeared. In contrast to $\mathrm{ZrO}_{2}$, monocoordinated hydroxyls on $\mathrm{PtZrO}_{2}$ did not reappear. Titration experiments of $\mathrm{PtZrO}_{2}$ with $\mathrm{CO}$ in the micro reactor flow setup with $\mathrm{MS}$ analysis revealed formation of $\mathrm{CO}_{2}$ and $\mathrm{H}_{2}$ at $300^{\circ} \mathrm{C}$ and $400^{\circ} \mathrm{C}$. Exposure of $\mathrm{PtZrO}_{2}$ to $\mathrm{CO}$ at $240^{\circ} \mathrm{C}$, however, did not result in any formation of $\mathrm{CO}_{2}$ and $\mathrm{H}_{2}$. The formation of $\mathrm{CO}_{2}$ and $\mathrm{H}_{2}$ at $300^{\circ} \mathrm{C}$ and $400^{\circ} \mathrm{C}$ stopped after a few seconds, indicating that surface hydroxyl groups were exhausted (as shown in Figures 6.5A-II and 6.5A-III). Treating $\mathrm{PtZrO}_{2}$ with water restored the activity, regenerating hydroxyl groups (not shown).

\subsubsection{CO adsorption on platinum}

$\mathrm{CO}$ adsorption on platinum was studied on $\mathrm{PtZrO}_{2}$ during the treatments with $\mathrm{CO}$. Figure 6.6 shows Transmission FT-IR spectra between $2100 \mathrm{~cm}^{-1}$ and $2000 \mathrm{~cm}^{-1}$ of 0.5 wt. $\% \mathrm{PtZrO}_{2}$ when subjected to $8 \mathrm{vol} . \% \mathrm{CO}$ in a temperature range of 240 to $400{ }^{0} \mathrm{C}$. At $240^{\circ} \mathrm{C}$, two peaks with a maximum at $2061 \mathrm{~cm}^{-1}$ and a shoulder at $2075 \mathrm{~cm}^{-1}$ are observed in the FT-IR spectrum and can be assigned to CO linearly adsorbed on platinum [31]. The intensity of both peaks was independent of temperature up to $280^{\circ} \mathrm{C}$. A further increase to $300{ }^{0} \mathrm{C}$ decreased the amount of adsorbed $\mathrm{CO}$. At $400^{\circ} \mathrm{C}, \mathrm{CO}$ adsorption on Pt reduced significantly.

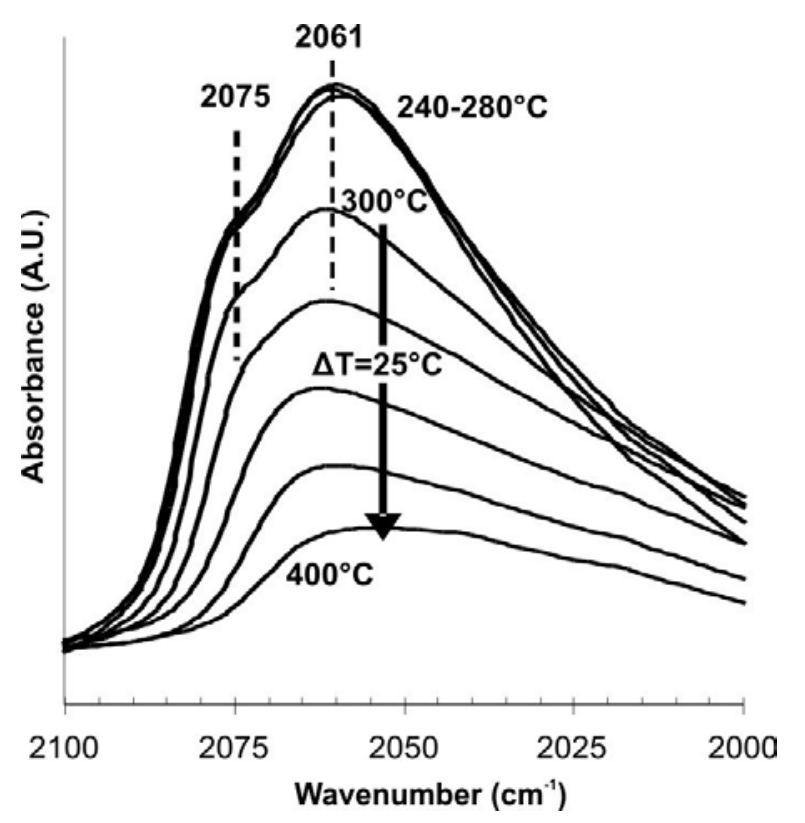

Figure 6.6: FT-IR spectra of $\mathrm{CO}$ adsorption on $\mathrm{PtZrO}_{2}$ at different temperatures. 


\subsection{Discussion}

\subsubsection{Characterization of $\mathrm{ZrO}_{2}$ and $\mathrm{PtZrO}_{2}$}

Transmission FT-IR characterization of monoclinic zirconia and $\mathrm{PtZrO}_{2}$ revealed two peaks that can be assigned to mono and multi-coordinated hydroxyl groups respectively (Figure 6.1) in agreement with literature [23-26]. Only marginal differences in intensities of mono- and multi-coordinated hydroxyl groups were observed between $\mathrm{ZrO}_{2}$ and $\mathrm{PtZrO}_{2}$ above $300^{\circ} \mathrm{C}$ under He. Thus, the differences observed in reactivity of hydroxyl groups are not due to differences in the initial amount of $\mathrm{OH}$ groups, and must be must be due to the presence of Pt as discussed below.

\subsubsection{Hydroxyl reactivity on $\mathrm{ZrO}_{2}$ towards $\mathrm{CO}$}

It was demonstrated in Figure 6.2 that mono-coordinated hydroxyls on $\mathrm{ZrO}_{2}$ reacted with $\mathrm{CO}$, resulting in formation of surface formate on $\mathrm{ZrO}_{2}$. Formate formation as a result of CO addition can be concluded based on the appearance of peaks at $2969 \mathrm{~cm}^{-1}$, $2886 \mathrm{~cm}^{-1}, 1560 \mathrm{~cm}^{-1}, 1384 \mathrm{~cm}^{-1}$ and $1371 \mathrm{~cm}^{-1}$. The peaks at $1560 \mathrm{~cm}^{-1}, 1384 \mathrm{~cm}^{-1}$ and $1371 \mathrm{~cm}^{-1}$ can be assigned to symmetric and asymmetric stretching vibrations of O-C$\mathrm{O}$ species. The presence of $\mathrm{O}-\mathrm{C}-\mathrm{O}$ is an indication for surface formate, but also surface carbonate could be responsible for O-C-O peaks [10]. However, the presence of C-H species is clear from the peaks at $2969 \mathrm{~cm}^{-1}$ and $2886 \mathrm{~cm}^{-1}$. The combined presence of $\mathrm{C}-\mathrm{H}$ and $\mathrm{O}-\mathrm{C}-\mathrm{O}$ vibrations indicate formate formation [10]. However, additional presence of surface carbonate cannot be ruled out. Several studies in literature claim the involvement of $\mathrm{CO}$ adsorbed on $\mathrm{Pt}$ in the formation of formate $[1,10]$. However, formate was also formed on zirconia without any $\mathrm{Pt}$ in our experiments, demonstrating that $\mathrm{Pt}$ is not necessary on the present catalyst. This view is supported by Ma et al. [21], who also reported formate formation between hydroxyls on $\mathrm{ZrO}_{2}$ and $\mathrm{CO}$ in the absence of platinum. In exact agreement with our results, formate formation in absence of $\mathrm{Pt}$ between $\mathrm{CO}$ and mono-coordinated hydroxyl groups on monoclinic zirconia was also reported in a recent paper by Korhonen et al. [32].

It was observed that increasing $\mathrm{CO}$ concentration resulted in increased consumption of mono-coordinated hydroxyls as well as formation of larger amounts of formate 
(Figure 6.2). This formate did not decompose into gaseous products. Formate formation proved to be reversible as removal of $\mathrm{CO}$ resulted in total recovery of mono-coordinated hydroxyl groups and disappearance of formate species on $\mathrm{ZrO}_{2}$ (Figure 6.3). Large amounts of formate were observed at $240^{\circ} \mathrm{C}$ but the amount decreased upon increasing the temperature to $400^{\circ} \mathrm{C}$, also accompanied by recovery of mono-coordinated hydroxyls (Figure 6.4). This shows that formate is thermodynamically favoured at low temperature. At higher temperatures the equilibrium is shifted to gas phase $\mathrm{CO}$ and mono-coordinated hydroxyl groups, obviously because of high entropy of CO in gas phase. Multi-coordinated hydroxyls on $\mathrm{ZrO}_{2}$ were not reactive towards $\mathrm{CO}$. From these observations, we conclude that formate can be formed on $\mathrm{ZrO}_{2}$ through an equilibrium reaction between $\mathrm{CO}$ and mono-coordinated hydroxyl groups as shown in Scheme 6.1 (step 1).

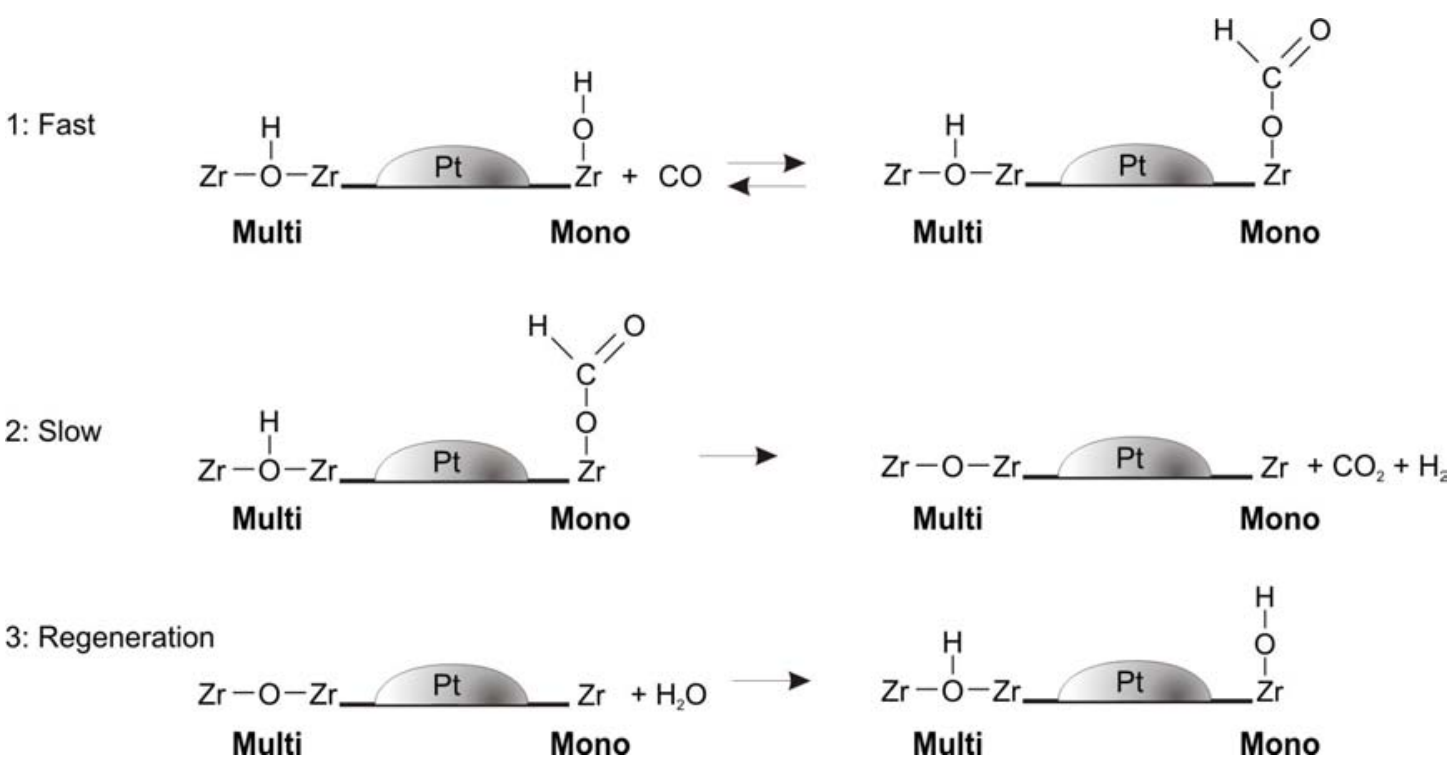

Scheme 6.1: Water gas shift reaction mechanism for $\mathrm{PtZrO}_{2}$. 1: Formate formation through reaction between $\mathrm{CO}$ and mono-coordinated hydroxyls 2: Formate decomposition involving Pt and multi-coordinated hydroxyls 3: Hydroxyl regeneration with water

\subsubsection{Hydroxyl reactivity on $\mathrm{PtZrO}_{2}$ towards $\mathrm{CO}$}

Identical to $\mathrm{ZrO}_{2}$, formation of formate through mono-coordinated hydroxyls was also observed on $\mathrm{PtZrO}_{2}$ at $240^{\circ} \mathrm{C}$ (Figure 6.5A). The formate peaks were located at the same wavenumbers on $\mathrm{PtZrO}_{2}$, indicating that the formate species on $\mathrm{ZrO}_{2}$ and $\mathrm{PtZrO}_{2}$ are identical. Apparently formate species on $\mathrm{PtZrO}_{2}$ do not interact 


\section{Chapter 6}

significantly with the Pt particles. $\mathrm{No}_{2}$ and $\mathrm{CO}_{2}$ formation occurred at $240^{\circ} \mathrm{C}$ on $\mathrm{PtZrO}_{2}$. This demonstrates that step 1 in Scheme 6.1 is also valid in case of $\mathrm{PtZrO}_{2}$.

Increasing the temperature to $300^{\circ} \mathrm{C}$ resulted in a decrease of surface formate and multi-coordinated hydroxyl groups on $\mathrm{PtZrO}_{2}$ (Figure 6.5). At $400^{\circ} \mathrm{C}$ hardly any multi-coordinated hydroxyls and surface formate were present on $\mathrm{PtZrO}_{2}$ (Figure 6.5). On $\mathrm{PtZrO}_{2}$ mono-coordinated hydroxyl groups were not recovered at temperatures above $300^{\circ} \mathrm{C}$ in contrast to $\mathrm{ZrO}_{2}$, which excludes formate decomposition to $\mathrm{CO}$ and mono-coordinated $\mathrm{OH}$ groups i.e. the reverse reaction 1 in Scheme 6.1 (comparing Figures 6.5A-I and 6.5A-III). Production of gas phase products $\left(\mathrm{CO}_{2}\right.$ and $\left.\mathrm{H}_{2}\right)$ on $\mathrm{PtZrO}_{2}$ was observed, starting at $300^{\circ} \mathrm{C}$. This shows that formate on $\mathrm{PtZrO}_{2}$ decomposes to $\mathrm{CO}_{2}$ and $\mathrm{H}_{2}$ at temperatures above $300^{\circ} \mathrm{C}$.

It was found that next to $\mathrm{H}_{2}$ and $\mathrm{CO}_{2}$ formation, simultaneous decrease of both surface formate and especially multi-coordinated hydroxyl groups occurred above $300^{\circ} \mathrm{C}$ on $\mathrm{PtZrO}_{2}$ (Figure 6.5). This suggests that multi-coordinated hydroxyl groups on $\mathrm{PtZrO}_{2}$ are involved in formate decomposition to $\mathrm{H}_{2}$ and $\mathrm{CO}_{2}$. Furthermore, this study showed that formate decomposition to gas phase products only occurs in the presence of Pt. Step 2 in Scheme 6.1 schematically depicts formate decomposition into $\mathrm{H}_{2}$ and $\mathrm{CO}_{2}$ by consumption of multi-coordinated hydroxyl groups in the presence of $\mathrm{Pt}$.

The relevance of these observations for the mechanism of WGS will now be discussed, assuming that formate is the relevant intermediate species at the relatively high temperatures used in this study. Formate formation proved to be an equilibrium reaction depending on the gas phase concentration of $\mathrm{CO}$ (Figure 6.2) and temperature (Figures 6.4 and 6.5). It was demonstrated that formate was already formed at $240^{\circ} \mathrm{C}$. As higher temperatures were required for formate decomposition, it seems likely that the decomposition is rate determining. This is in agreement with Pigos et al. who identified $\mathrm{C}-\mathrm{H}$ bond breaking in formate as the rate determining step in WGS mechanism [10]. Pigos et al. [10] proposed that platinum assists in abstracting $\mathrm{H}$ from the formate $\mathrm{C}-\mathrm{H}$ bond to enable the complex to dissociate into $\mathrm{H}_{2}$ and $\mathrm{CO}_{2}$, based on hydrogen-deuterium exchange experiments in formate over $\mathrm{ZrO}_{2}$ and $\mathrm{PtZrO}$. H-D exchange in formate hardly occurred without Pt, whereas Pt increased the exchange rate significantly. Our results confirm that $\mathrm{Pt}$ is required for the formate 
decomposition and additionally demonstrate the involvement of multi-coordinated hydroxyl groups in the decomposition of formate. However, hydrogen abstraction from formate and subsequent recombination of this hydrogen atom adsorbed on $\mathrm{Pt}$ with a hydrogen atom of a multi-coordinated hydroxyl group seems not very likely, as the $\mathrm{O}-\mathrm{H}$ bond is very strong. Therefore, we suggest that a concerted mechanism occurs in formate decomposition. The multi-coordinated $\mathrm{OH}$ group and the $\mathrm{Pt}$ surface both interact with the formate complex simultaneously, breaking the $\mathrm{C}-\mathrm{H}$ bond in the formate and the $\mathrm{O}-\mathrm{H}$ bond in the multi-coordinated $\mathrm{OH}$ group, forming $\mathrm{CO}_{2}$ and $\mathrm{H}_{2}$ in one concerted step.

The experimental observation that decomposition of formate to $\mathrm{CO}_{2}$ and $\mathrm{H}_{2}$ takes place exclusively in the presence of platinum, would suggest that formate species located close to a metal particle decompose faster than a formate species positioned remotely from metal particles. This would seriously complicate the interpretation of the experimental result reported by Tibiletti et al. [11], showing a much slower response of the formate IR signals when feeding labeled CO in DRIFT measurements as compared to the kinetics of the reaction. Based on this, it was concluded that formate is not involved in the rate determining step and is a spectator instead in water gas shift reaction at $200^{\circ} \mathrm{C}$. However, a slow response of formate species can also be explained by assuming that part of the formate species are located far away from $\mathrm{Pt}$ particles and surface diffusion is required for formate decomposition at the $\mathrm{Pt}$ particles. Relatively slow surface diffusion of formate could well result in slow response of the formate IR signals to the isotopic step change. It should be noted that mono-coordinated hydroxyl groups were almost completely converted (figure 5), when treating $\mathrm{Pt} / \mathrm{ZrO}_{2}$ with $\mathrm{CO}$ above $300^{\circ} \mathrm{C}$. This demonstrates the mobility of both formate species as well as bridged $\mathrm{OH}$ groups in order to interact with $\mathrm{Pt}$ on the zirconia surface, eventually resulting in consumption of all available monocoordinated surface OH-groups. Unfortunately, our experiments did not allow accurate determination of the dynamics of those events.

It should be noted that the conclusions drawn so far were obtained in experiments with surface hydroxyl groups, without any gas phase water present. Two possible roles for water in the reaction mechanism are proposed in literature [9]. The role of water is either decomposition of formate (and simultaneous reoxidation of zirconia 


\section{Chapter 6}

and regeneration of hydroxyl groups) or regeneration of the zirconia support exclusively. It was demonstrated in transient experiments that $\mathrm{CO}_{2}$ and $\mathrm{H}_{2}$ could be formed on hydroxylated $\mathrm{PtZrO}_{2}$ during titration studies with $\mathrm{CO}$, in the absence of water. As described extensively in earlier work by our group [1], product formation of $\mathrm{PtZrO}_{2}$ stopped when the hydroxyl groups were exhausted. After pulsing water to the "exhausted" catalyst, complete regeneration of hydroxyl groups on $\mathrm{PtZrO}_{2}$ was accomplished, demonstrated by complete recovery of the reactivity of the catalyst in reaction with $\mathrm{CO}$ to $\mathrm{CO}_{2}$. We therefore conclude that the exclusive role of water is regeneration of the hydroxyl groups and simultaneous re-oxidation of the support.

DFT calculations $[28,33]$ showed that the dissociation of water involves adsorption of water on a zirconium ion, resulting in the formation of one mono-coordinated and one multi-coordinated hydroxyl group. We showed that one mono-coordinated and one multi-coordinated hydroxyl group are consumed during water gas shift reaction of one $\mathrm{CO}$ molecule. Regeneration of both hydroxyl groups with one water molecule leads to a stoichiometrically balanced reaction for water gas shift.

Our current experiments with continuous presence of $\mathrm{CO}$ and earlier results in $\mathrm{CO}$ pulsing experiments by Azzam et al. [1] demonstrated that oxygen of the support was consumed during reaction with $\mathrm{CO}$ and thus partial reduction of the zirconia takes place. It was shown by Azzam et al. that after regeneration of an "exhausted" zirconia surface with $\mathrm{N}_{2} \mathrm{O}$, also reaction of $\mathrm{CO}$ to $\mathrm{CO}_{2}$ was possible. It was found by Zhu [34] that activation of $\mathrm{N}_{2} \mathrm{O}$ on zirconia takes place at structural defect sites (i.e. low coordinated $\mathrm{Zr}$-cations located edges and corners). Zhu also showed that the structural defects did not react with $\mathrm{O}_{2}$. Based on the fact that the amount of $\mathrm{CO}_{2}$ formed during exposure to $\mathrm{CO}$ is similar after re-oxidation with $\mathrm{H}_{2} \mathrm{O}$ compared to $\mathrm{N}_{2} \mathrm{O}$ [1], it follows that reduction of zirconia under WGS reaction conditions is limited to the structural defect sites. Scheme 6.2 illustrates the regeneration step with water on a defective $\mathrm{Zr}^{3+}$-cation. Water dissociation creates a mono-coordinated $\mathrm{OH}$-group on the structural defect site and a multi-coordinated $\mathrm{OH}$-group on a neighbouring oxygen atom. It is proposed that in case of regeneration with water, the formed monocoordinated $\mathrm{OH}$-group on the defect site can react with $\mathrm{CO}$ to form formate. The surface formate can be converted with use of the multi $\mathrm{OH}$ group to $\mathrm{H}_{2}$ and $\mathrm{H}_{2} \mathrm{O}$, assisted by Pt. To summarize, we need to precise our previous conclusion on the 
reaction pathway for WGS on $\mathrm{PtZrO}_{2}$ via "formate and redox regeneration" [1], in the sense that the redox step is limited to structural defect sites on zirconia.

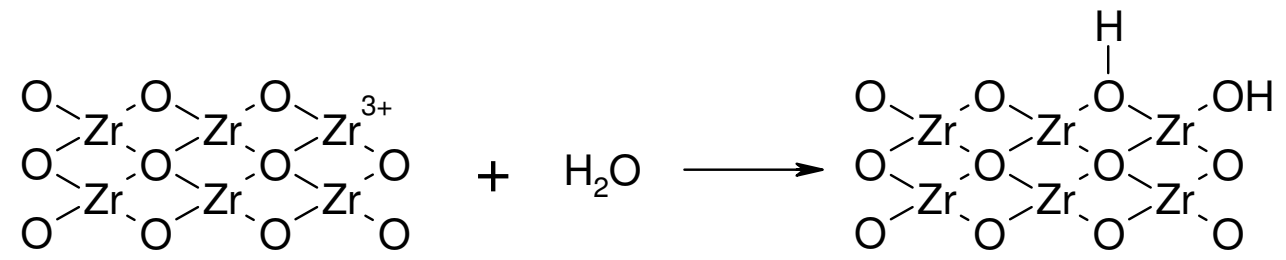

Scheme 6.2: Proposed regeneration of surface hydroxyl and simultaneous reoxidation of $\mathrm{ZrO2}$, taking place on structural defects

The regeneration of the hydroxyl groups on $\mathrm{ZrO}_{2}$ is also depicted more schematically in Scheme 6.1 (step 3). This leads to the following overall reaction steps in WGS: First, CO reacts with one mono hydroxyl group to form formate which is subsequently converted with a multi-coordinated hydroxyl group to $\mathrm{H}_{2}$ and $\mathrm{CO}_{2}$ in the presence of Pt. Finally, the hydroxyl groups on the $\mathrm{ZrO}_{2}$ surface are regenerated by water dissociation.

In this mechanism $\mathrm{CO}$ activation on $\mathrm{Pt}$ is not required to produce formate on $\mathrm{ZrO}_{2}$ (Figures 6.2, 6.3 and 6.4). Identical formate species were detected in presence of $\mathrm{Pt}$ (Figure 6.5). Figure 6.6 shows that high $\mathrm{CO}$ coverage on $\mathrm{Pt}$ can be expected below $300^{\circ} \mathrm{C}$. Starting at $300^{\circ} \mathrm{C}$, the intensity of adsorbed $\mathrm{CO}$ on Pt decreased, indicating a lower surface coverage. Exactly at the same temperature, formation of gas phase products was initiated. This demonstrates that adsorption of carbon monoxide on platinum could have a negative influence on water gas shift reaction, occupying $\mathrm{Pt}$ sites and preventing formate decomposition below $300^{\circ} \mathrm{C}$. At temperatures above $300^{\circ} \mathrm{C}$, the lower $\mathrm{CO}$ coverage on $\mathrm{Pt}$ increases accessibility of Pt sites, enhancing formate decomposition to $\mathrm{H}_{2}$ and $\mathrm{CO}_{2}$. 


\subsection{Conclusion}

The main goal of this study was to determine the reactivity of hydroxyl groups on $\mathrm{Pt} / \mathrm{ZrO}_{2}$ in the water gas shift reaction. It was shown in this paper that two types of hydroxyl groups are present on monoclinic zirconia: mono- and multi-coordinated hydroxyls. Mono-coordinated hydroxyls are involved in formate formation, while multi-coordinated hydroxyls are needed for formate decomposition. Platinum is not involved in the formation of formate, in contrast, Pt is needed to enable formate decomposition, resulting in formation of $\mathrm{CO}_{2}$ and $\mathrm{H}_{2}$. These results imply that the reactivity of formate species depend on the distance to Pt particles.

In addition to the formate mechanism with redox regeneration proposed earlier for WGS on $\mathrm{Pt} / \mathrm{ZrO}_{2}$ by Azzam [1], it was found in this study that reduction of the support was limited to structural defective zirconia sites at edges and kinks. These sites can be regenerated with water, implying that the role of water in the WGS mechanism is regeneration of hydroxyl groups and simultaneous re-oxidation of $\mathrm{ZrO}_{2}$. 


\subsection{References}

[1] K.G. Azzam, I.V. Babich, K. Seshan, L. Lefferts, Journal of Catalysis 251 (2007) 153-162.

[2] W.C. Lattin, V.P. Utgikar, International Journal of Hydrogen Energy 32 (2007) 3230-3237.

[3] K.B. Prater, Journal of Power Sources 51 (1994) 129-144.

[4] W. Ruettinger, O. Ilinich, R.J. Farrauto, Journal of Power Sources 118 (2003) 61-65.

[5] J.-H. Wee, Renewable and Sustainable Energy Reviews 11 (2007) 1720-1738.

[6] F. Mueller-Langer, E. Tzimas, M. Kaltschmitt, S. Peteves, International Journal of Hydrogen Energy 32 (2007) 3797-3810.

[7] T.V. Choudhary, D.W. Goodman, Catalysis Today 77 (2002) 65-78.

[8] K. Takanabe, K.-i. Aika, K. Inazu, T. Baba, K. Seshan, L. Lefferts, Journal of Catalysis 243 (2006) 263-269.

[9] K. Ledjeff-Hey, J. Roes, R. Wolters, Journal of Power Sources 86 (2000) 556561.

[10] J.M. Pigos, C.J. Brooks, G. Jacobs, B.H. Davis, Applied Catalysis A: General 328 (2007) 14-26.

[11] D. Tibiletti, F.C. Meunier, A. Goguet, D. Reid, R. Burch, M. Boaro, M. Vicario, A. Trovarelli, Journal of Catalysis 244 (2006) 183-191.

[12] T. Bunluesin, R.J. Gorte, G.W. Graham, Applied Catalysis B: Environmental 15 (1998) 107-114.

[13] D.C. Grenoble, M.M. Estadt, D.F. Ollis, Journal of Catalysis 67 (1981) 90-102.

[14] P. Panagiotopoulou, A. Christodoulakis, D.I. Kondarides, S. Boghosian, Journal of Catalysis 240 (2006) 114-125.

[15] X. Wang, R.J. Gorte, Applied Catalysis A: General 247 (2003) 157-162.

[16] K. Takanabe, K.-i. Aika, K. Seshan, L. Lefferts, Journal of Catalysis 227 (2004) 101-108.

[17] S.Y. Choung, M. Ferrandon, T. Krause, Catalysis Today 99 (2005) 257-262.

[18] H. Iida, A. Igarashi, Applied Catalysis A: General 303 (2006) 48-55.

[19] T. Shido, Y. Iwasawa, Journal of Catalysis 141 (1993) 71-81.

[20] F.C. Meunier, D. Tibiletti, A. Goguet, D. Reid, R. Burch, Applied Catalysis A: General 289 (2005) 104-112.

[21] Z.-Y. Ma, C. Yang, W. Wei, W.-H. Li, Y.-H. Sun, Journal of Molecular Catalysis A: Chemical 231 (2005) 75-81.

[22] A.A. Tsyganenko, V.N. Filimonov, Journal of Molecular Structure 19 (1973) 579-589.

[23] P.A. Agron, E.L. Fuller, H.F. Holmes, Journal of Colloid and Interface Science 52 (1975) 553-561.

[24] X. Chen, S. Huang, D. Cao, W. Wang, Fluid Phase Equilibria 260 (2007) 146152.

[25] C.K. Loong, J.W. Richardson, M. Ozawa, Journal of Catalysis 157 (1995) 636644.

[26] T. Merle-Méjean, P. Barberis, S.B. Othmane, F. Nardou, P.E. Quintard, Journal of the European Ceramic Society 18 (1998) 1579-1586.

[27] B. Bachiller-Baeza, I. Rodriguez-Ramos, A. Guerrero-Ruiz, Langmuir 14 (1998) 3556-3564. 
[28] S.T. Korhonen, M. Calatayud, A.O.I. Krause, J. Phys. Chem. C 112 (2008) 6469-6476.

[29] P.O. Graf, B.L. Mojet, J.G. van Ommen, L. Lefferts, Applied Catalysis A: General 332 (2007) 310-317.

[30] E. Knozinger, K.H. Jacob, S. Singh, P. Hofmann, Surface Science 290 (1993) 388-402.

[31] P. Pillonel, S. Derrouiche, A. Bourane, F. Gaillard, P. Vernoux, D. Bianchi, Applied Catalysis A: General 278 (2005) 223-231.

[32] S.T. Korhonen, M. Calatayud, A.O.I. Krause, J. Phys. Chem. C (2008).

[33] A. Ignatchenko, D.G. Nealon, R. Dushane, K. Humphries, Journal of Molecular Catalysis A: Chemical 256 (2006) 57-74.

[34] Z. Jianjun, S. Albertsma, J.G. van Ommen, L. Lefferts, Journal of Physical Chemistry B 109 (2005) 9550-9555. 


\section{Chapter}

\section{Conclusions}

\subsection{Introduction}

The research discussed in this thesis and the parallel work by Tymen Tiemersma evaluated the possibilities of combining the oxidative coupling and reforming of methane in one multifunctional reactor. Several aspects related to catalyst and reactor development were investigated and are described in the two $\mathrm{PhD}$ theses. The main conclusions are summarized in this chapter, leading to ideas for further research and future reactors in oxidative coupling and reforming. Figure 7.1 summarizes the reactions taking place in the combined process.

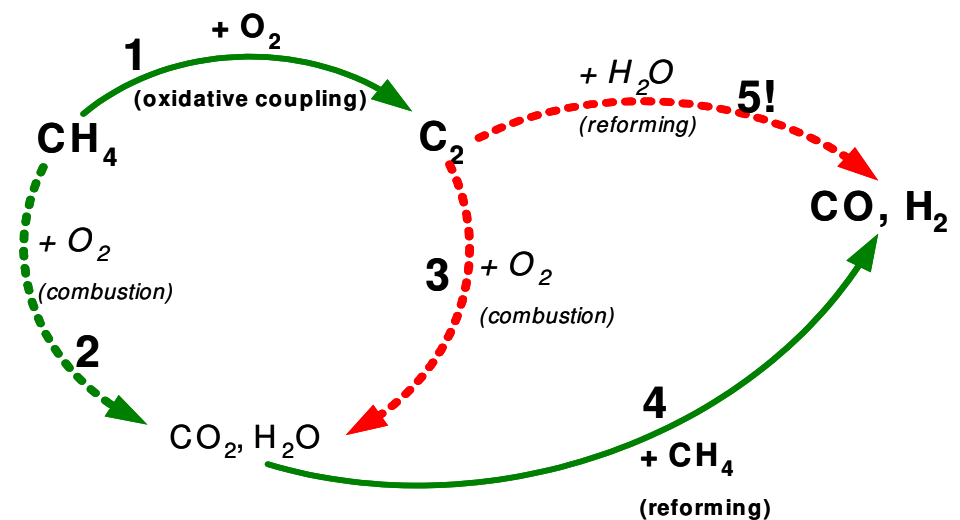

Figure 7.1: Reactions occurring in combined process of methane coupling and steam reforming

Methane coupling produces C2 hydrocarbons (ethane and ethylene) and water (1). The side combustion reactions of methane (2) and C2-hydrocarbons (3) produce water and $\mathrm{CO}_{2}$, which can react with the remaining methane through steam or dry reforming 
to $\mathrm{CO}$ and $\mathrm{H}_{2}$ (4). The main challenge in the reaction concept is to suppress steam/dry reforming of ethane and ethylene (5!) in order to avoid complete reaction to synthesis gas. The main topics covered in the project were:

(i) development of steam reforming catalyst able to reform only methane selectively in presence of ethane and ethylene

(ii) optimization of oxidative coupling process and catalyst formulation

(iii) development of a reactor concept based on the insights gained in both processes

(iv) the mechanism of activation of water on zirconia was investigated, using water gas shift as a model reaction

\subsection{Reforming competition (chapter 2, 3 and 4)}

Chapter 2 discussed a comparative study of methane, ethane and ethylene steam reforming on $\mathrm{Pt}, \mathrm{Rh}$ and $\mathrm{Pd}$ on YSZ (yttrium-stabilized zirconia). The intention was to develop a methane selective steam reforming catalyst, showing low reactivity towards ethane and ethylene. Both, reactivity and composition of products varied depending on the reforming catalyst. The order of activity of separate hydrocarbons on Rh was $\mathrm{C}_{2} \mathrm{H}_{6}>\mathrm{C}_{2} \mathrm{H}_{4}>\mathrm{CH}_{4}$. On $\mathrm{Pt}$, methane reacted faster than the $\mathrm{C} 2$ hydrocarbons: $\mathrm{CH}_{4}>\mathrm{C}_{2} \mathrm{H}_{6} \approx \mathrm{C}_{2} \mathrm{H}_{4}$. Concerning the target process of methane coupling combined with reforming, $\mathrm{Pt}$ is considered the most promising metal because $\mathrm{C} 2$ hydrocarbons are converted less than methane. Additionally, PtYSZ was the most stable catalyst. The higher reactivity of $\mathrm{Rh}$ towards $\mathrm{C} 2$ hydrocarbons relates to findings in literature; $\mathrm{Rh}$ shows a higher binding strength of carbon atoms than $\mathrm{Pt}$, indicating a higher reactivity in C-C scission reactions $[1,2]$. On PtYSZ, the steam reforming reactions resulted in synthesis gas exclusively. It was shown that both synthesis gas and methane were formed during steam reforming of ethane on RhYSZ. Hydrogenolysis of ethane occurred on this catalyst as a consecutive reaction, consuming hydrogen produced in ethane steam reforming via hydrogenolysis of unconverted ethane. This showed that effective steam reforming of higher hydrocarbons can only be achieved when the activity for hydrogenolysis is limited, avoiding production of methane.

Reforming experiments with mixtures of methane/ethylene showed that preferential conversion of ethylene occurred on PtYSZ. It was also found that in methane/ethane 
mixtures, methane and ethane competed for active sites on Pt. It was found that ethane provides a high surface coverage of $\mathrm{C}_{\mathrm{x}} \mathrm{H}_{\mathrm{y}}$ fragments in steam reforming of methane and ethane mixtures. In mixtures of methane and ethane water activation is the rate limiting step in the mechanism on PtYSZ, in contrast to the mechanism for methane reforming as reported by Wei with hydrocarbon activation as the rate limiting step [35]. The addition of potassium to PtYSZ (chapter 3 and 4) resulted in weaker adsorption of methane and ethane on the Pt surface, indicated by weakened adsorption of $\mathrm{CO}$ in FT-IR TPD on Pt4K700. With potassium addition the hydrocarbon activation on Pt became rate determining for mixtures of methane and ethane, induced by low surface coverage of methane and ethane in this case, in agreement with the results of Wei [3-5]. As a result, competition effects of methane and ethane were diminished on potassium modified PtYSZ, enabling simultaneous conversion of methane and ethane. Unfortunately, ethane conversion is not suppressed by the addition of potassium. A catalyst that clearly suppresses ethane conversion would be needed to make the overall concept of oxidative coupling combined with steam reforming applicable in one reactor compartment. In conclusion it can be said that it is unlikely that a methane selective catalyst for the steam reforming process can be developed.

\subsection{Role of hydroxyl groups in water shift on $\mathrm{PtZrO}_{2}$ (chapter 6)}

The activation of water on zirconia was investigated, using water gas shift as a model reaction (chapter 6). It was shown that water induces the presence of two types of hydroxyl groups on monoclinic zirconia: mono- and multi-coordinated hydroxyls. Both types are active in the water gas shift mechanism, but they have different functionalities. Mono coordinated hydroxyls are involved in reaction with $\mathrm{CO}$ to the intermediate formate, while multi coordinated hydroxyls play a role in formate decomposition. Platinum was not necessary for formate formation and was found to play a role in formate decomposition/product formation. The reaction products, $\mathrm{CO}_{2}$ and $\mathrm{H}_{2}$ were formed on $\mathrm{Pt} / \mathrm{ZrO}_{2}$ when subjected to $\mathrm{CO}$, even in the absence of water. In addition to the formate mechanism with redox regeneration for WGS on $\mathrm{Pt} / \mathrm{ZrO}_{2}$ as proposed by Azzam [6], it was found in this study that reduction of the support was limited to structural defective zirconia sites at edges and kinks, hosting the mono- 
coordinated hydroxyl groups. The mechanistic insights gained in this study provide new possibilities to improve water gas shift catalysts by optimizing the availability of mono- and multi-coordinated groups on the support. Also, application of a metal with low affinity towards CO-adsorption and the ability to efficiently decompose formate, could improve reaction rates in water gas shift.

\subsection{Catalyst and reactor optimization oxidative coupling}

Extensive tests on the $\mathrm{Mn} / \mathrm{Na}_{2} \mathrm{WO}_{4} / \mathrm{SiO}_{2}$ oxidative coupling catalyst in both co-feed and membrane reactors were performed in the parallel project by Tymen Tiemersma and are described in detail in his $\mathrm{PhD}$ thesis [7]. In co-feed tests a maximum C2-yield of only $12 \%$ was obtained, lower than comparable to yields reported in literature on the same catalyst [8-12]. Use of a membrane reactor was a challenging issue: the currently available ceramic membranes deliver too high oxygen fluxes and showed stability problems at temperatures around $850^{\circ} \mathrm{C}$. This shows that development of new membranes is required for optimal operation of oxidative coupling. However, already with the current membranes selectivity to $\mathrm{C} 2$ products could be increased from $60 \%$ in co-feed operation to $65 \%$ in the membrane reactor, induced by lower oxygen partial pressure and better temperature control. As a result, C2 yield was increased to $20 \%$. The main advantage of operation in a membrane reactor is energy production over the entire length of the reactor, instead of instantaneous steep temperature increase at the reactor entrance, occurring in co feed operation because of higher oxygen concentration at the reactor entrance. This offers interesting possibilities to combine a coupling reactor for oxidative coupling with a steam reforming reactor. 


\subsection{Reactor concepts (chapter 5)}

The type of reactor concept that can be used strongly depends on the following issues.

The main conclusions obtained are shortly mentioned for each issue:

1. Oxidation reactions of hydrocarbons on steam reforming catalyst should be prevented.

- Avoiding combustion reactions on (metal) steam reforming catalysts seems too difficult and therefore no research was performed on this topic. This means that a reactor or catalyst concept that avoids contact between oxygen and the reforming catalyst is required.

2. Reforming activity of ethane and ethylene can convert the complete mixture to synthesis gas and has to be limited.

- Development of a steam reforming catalyst that selectively converts methane was not successful. This means that a suitable reactor concept or catalyst configuration has to be chosen, in order to avoid contact between C2 hydrocarbons and the reforming catalyst.

3. The overall process combines the highly exothermic coupling and combustion reactions with the endothermic reforming, requiring optimized heat transfer between both processes.

- Combining both processes in one catalyst particle or using one multifunctional catalyst can provide autothermal operation, if a support material with good conductive properties is used.

- Heat transfer in separate reactions zones or reactor compartments can be optimized by limiting the distance between exothermic and endothermic zones, e.g. using small reactor tubes or even micro reactor systems.

4. High oxygen concentration leads to unselective oxidation reactions in the OCM section, producing $\mathrm{CO}_{2}$ and $\mathrm{H}_{2} \mathrm{O}$. To increase $\mathrm{C} 2$ yield and minimize combustion reactions a low oxygen partial pressure is needed in the OCM section.

- It was demonstrated that use of a membrane reactor with distributed oxygen feeding can significantly increase selectivity and yield of ethylene and distribute energy production in oxidative coupling more evenly over the reactor. 
Based on the results summarized above, Figure 7.2 shows two promising reactor concepts selected from the options as discussed in the Introduction section (Figure 1.2) to combine the oxidative coupling and steam reforming of methane. Both concepts will be discussed more in detail here.
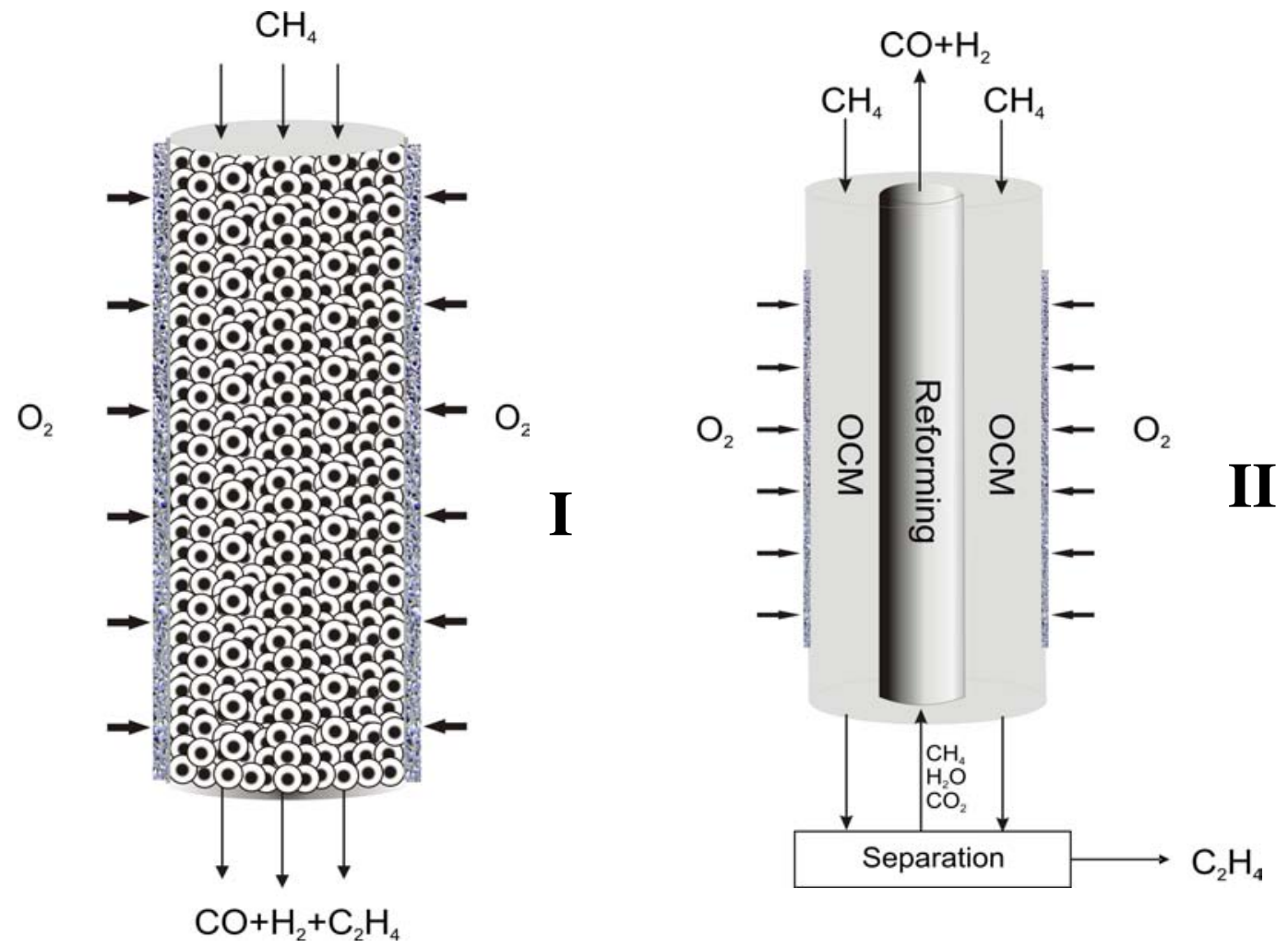

Figure 7.2: Selected reactor concepts for integration of oxidative coupling and reforming of methane, using combined catalyst particles (I) or combination of processes on reactor scale (II)

In the first concept, an eggshell catalyst is applied (Figure 7.2-I) to avoid contact between oxygen and the hydrocarbons on the reforming catalyst, eliminating combustions reactions on the reforming catalyst. The oxidative coupling catalyst is placed in the shell and the reforming function in the core of the catalyst. Oxygen present in the gas phase should be consumed in the outer layer of the particle to avoid diffusion to the core. In the core, in principle a methane selective reforming catalyst is required to avoid reforming of ethane and ethylene. This shell and core system enables excellent heat exchange between the processes, requiring support materials with good conductivity. However, the development of a methane selective catalyst was not successful, meaning that ethane and ethylene should not reach the particle 
center. To reduce diffusion of these components to the particle center a catalyst particle with the structure indicated in Figure 7.3 is needed.

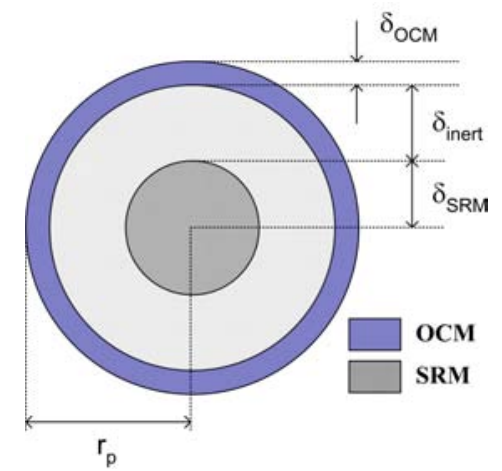

Figure 7.3: Schematic view of multifunctional catalyst particle, consisting of an outer layer of oxidative coupling catalyst (OCM), a diffusion layer and a core of methane steam reforming catalyst (SRM).

The reforming function (inner layer) and the oxidative coupling function (outer layer) are combined with an inert layer in one catalyst particle. Due to a higher diffusion coefficient of $\mathrm{CH}_{4}$, methane will reach the particle more easily than $\mathrm{C} 2$ hydrocarbons. As a result the amount of $\mathrm{C} 2$ hydrocarbons reformed will be relatively low. The combined catalyst particle should convert methane and oxygen to ethylene and synthesis gas. Numerical modelling of such a catalyst particle was performed using the kinetic model by Stansch [13] for oxidative coupling and reforming kinetics of $\mathrm{Xu}$ [14]. The possibility of auto thermal operation and net production of ethylene was demonstrated [7]. For low ethylene gas phase concentrations, it was shown that additional methane conversion to synthesis gas through steam reforming can consume energy produced in oxidative coupling, without significant consumption of ethane or ethylene. This concept only works at low $\mathrm{C} 2$ yield, because of much higher methane concentration, as compared to ethylene concentration. At high gas phase concentrations of ethylene, combustion reactions limit ethylene yields in oxidative coupling. The practical feasibility of synthesizing these catalyst particles and experimental demonstration of this concept offer challenging possibilities for future work. 
As shown in figure 7.2 II, the oxidative coupling and reforming processes can also be separated on reactor scale by using separate reactor compartments. The advantage of concepts coupled on reactor scale is the higher flexibility in terms of intermediate reactions and separation steps: after the oxidative coupling process ethylene can be separated from the product mixture before the steam reforming section of the process (Figure 7.2 II), accepting that selective reforming of methane is not possible in presence of ethylene.

A possible concept was discussed more in detail in chapter 5 involving reactive separation of ethylene to ethylbenzene (equation 7.1):

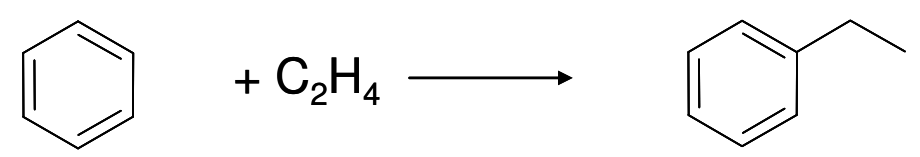

Figure 7.4 schematically shows a process scheme of the proposed concept. The oxidative coupling is carried out in a membrane reactor, producing $\mathrm{C}_{2} \mathrm{H}_{4}$ and $\mathrm{C}_{2} \mathrm{H}_{6}$ (1). The membrane reactor secures high selectivity to ethylene. Production of ethane should be avoided here: ethane is not reactive with benzene and is eventually lost to synthesis gas in the reforming step (4). The product mixture also contains remaining $\mathrm{CH}_{4}$ and produced $\mathrm{CO}, \mathrm{CO}_{2}, \mathrm{H}_{2} \mathrm{O}$ and small amounts of $\mathrm{H}_{2}$. Excess benzene is added to this stream to react with ethylene to ethylbenzene around $360^{\circ} \mathrm{C}$ (2). Yields of EB up to $90 \%$ were found at $95 \%$ conversion and $90 \%$ selectivity at $360^{\circ} \mathrm{C}$ on ZSM-5. Methane and ethane present in the feed were not converted and can be used for steam reforming. None of the additional components present in the effluent gas of oxidative coupling $\left(\mathrm{CO}, \mathrm{CO}_{2}, \mathrm{CH}_{4}, \mathrm{C}_{2} \mathrm{H}_{6}\right.$ and $\left.\mathrm{H}_{2} \mathrm{O}\right)$ influences activity or selectivity of the alkylation catalyst. Stability of ZSM-5 is also not influenced by the added components, with the exception of water, which even improves stability. 


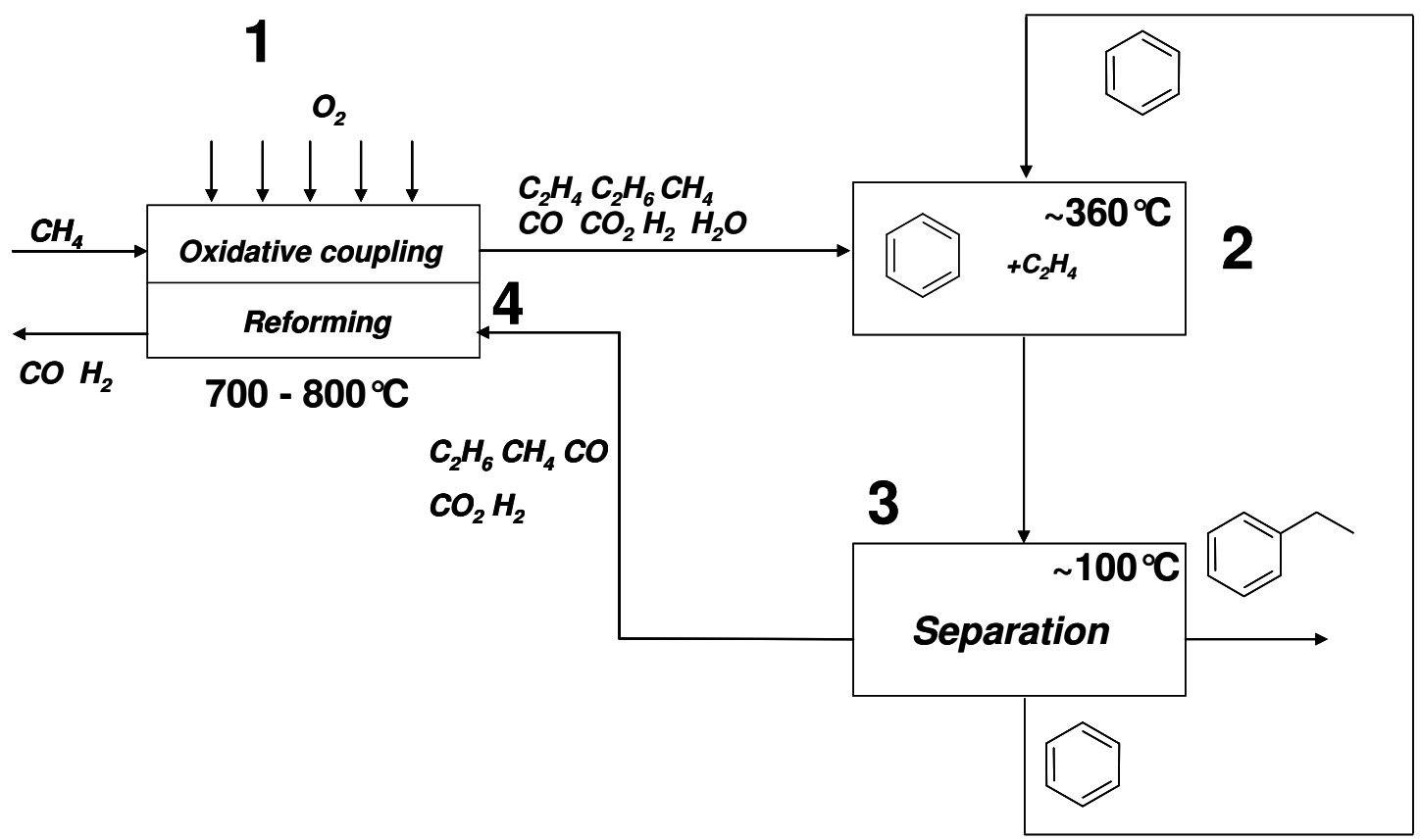

Figure 7.4: Possible process scheme of combined oxidative coupling and reforming of methane with ethylene reactive ethylene separation via alkylation of benzene

After the alkylation reaction, benzene and ethylbenzene are separated from the reaction mixture by distillation, recycling benzene to reactor (2). The remaining stream is fed to the reforming reactor (4), consuming the excess heat generated in the coupling process. The steam reforming catalyst needs to show high activity towards both methane and ethane, intending to convert all remaining hydrocarbons. An inexpensive commercial $\mathrm{Ni}$ catalyst could be an option, as deactivation through coking is less pronounced after removal of ethylene. The total process will convert methane and oxygen to synthesis gas and ethylbenzene. Efficient heat exchange between reactant and product streams is needed to make this concept feasible.

A remaining question in this concept is how to combine the oxidative coupling and reforming efficiently in one reactor. Performing oxidative coupling with distributed oxygen feeding proved to be beneficial [7] for ethylene selectivity and avoided the highly exothermic combustion reactions to a large extent. An additional advantage of using distributed feeding is that low oxygen partial pressure guarantees smaller temperature gradients and energy production over the entire length of the reactor, instead of instantaneous steep increase of temperature at the reactor entrance. Reverse 
flow operation of oxidative coupling could provide low temperature inlet and outlet streams $[15,16]$.

A possible configuration with oxidative coupling in horizontal tubes and reforming in the fluidized bed is shown in Figure 7.5. The processes are only coupled in terms of heat exchange between the endothermic reforming and exothermic oxidative coupling. With its excellent heat transfer properties, a fluidized bed reactor for the parallel steam reforming could provide an ideal heat sink for the reverse flow membrane reactor. The proposed total reactor concept consisting of reverse flow membrane tubes for oxidative coupling and a fluidized bed for steam reforming is schematically depicted in Figure 7.5. Numerical simulation [7] demonstrated the possibility of applying this concept and experimental demonstration of the concept is a challenging task for future research.

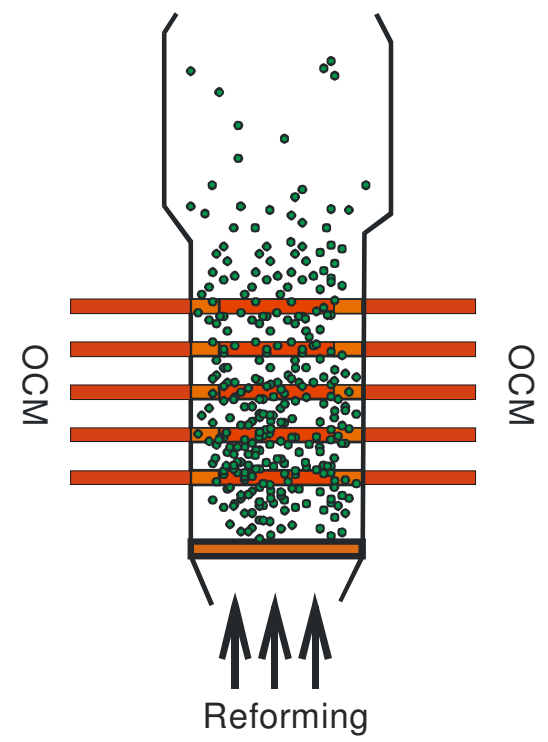

Figure 7.5: Schematic view of reactor concept with reverse flow membrane tubes for oxidative coupling of methane, integrated with fluidized bed for steam reforming 


\subsection{References}

[1] A.V. Zeigarnik, R.E. Valdes-Perez, O.N. Myatkovskaya, Journal of Physical Chemistry B 104 (2000) 10578.

[2] E.H.v. Broekhoven, V. Ponec, Progress in Surface Science 19 (1985) 351.

[3] J. Wei, E. Iglesia, Journal of Physical Chemistry B 108 (2004) 4094-4103.

[4] J.M. Wei, E. Iglesia, Journal of Catalysis 225 (2004) 116.

[5] J.M. Wei, E. Iglesia, Physical Chemistry Chemical Physics 6 (2004) 3754.

[6] K.G. Azzam, I.V. Babich, K. Seshan, L. Lefferts, Journal of Catalysis 251 (2007) 153-162.

[7] T. Tiemersma, PhD thesis, University of Twente, to be published (2009).

[8] S.F. Ji, T.C. Xiao, S.B. Li, L.J. Chou, B. Zhang, C.Z. Xu, R.L. Hou, A.P.E. York, M.L.H. Green, Journal of Catalysis 220 (2003) 47.

[9] A. Malekzadeh, M. Abedini, A.A. Khodadadi, M. Amini, H.K. Mishra, A.K. Dalai, Catalysis Letters 84 (2002) 45.

[10] S. Pak, J.H. Lunsford, Applied Catalysis A: General 168 (1998) 131.

[11] S. Pak, P. Qiu, J.H. Lunsford, Journal of Catalysis 179 (1998) 222.

[12] A. Palermo, J.P.H. Vazquez, A.F. Lee, M.S. Tikhov, R.M. Lambert, Journal of Catalysis 177 (1998) 259.

[13] Z. Stansch, L. Mleczko, M. Baerns, Industrial \& Engineering Chemistry Research 36 (1997) 2568-2579.

[14] J. Xu, G.F. Froment, AIChE Journal 35 (1989) 88-96.

[15] M. van Sint Annaland, W.P.M. van Swaaij, H.A.R. Scholts, J.A.M. Kuipers, Chemical Engineering Science 57 (2002) 833-854.

[16] M. van Sint Annaland, W.P.M. van Swaaij, H.A.R. Scholts, J.A.M. Kuipers, Chemical Engineering Science 57 (2002) 855-872. 



\section{Dankwoord \\ Acknowledgements}

De afgelopen 4 jaar heb ik op de Universiteit Twente gewerkt aan mijn promotieonderzoek in de vakgroep katalytische processen en materialen. In deze tijd heb ik veel geleerd en me verder ontwikkeld op zowel vakkennis als op persoonlijk vlak. Ik ben iedereen die mij op welke manier dan ook heeft geholpen zeer dankbaar.

Leon, ik wil je bedanken voor de begeleiding gedurende dit onderzoek. Jouw kritische kijk op het onderzoek en precisie bij het schrijven van publicaties hebben dit werk wetenschappelijk naar een hoger niveau getild. Het was erg prettig om steeds snel reactie op documenten, posters en presentaties te krijgen.

Barbara, ontzettend bedankt voor alle hulp en ondersteuning in dit onderzoek. Ik vind het ontzettend knap hoe je steeds voor me klaar stond en heb erg van onze samenwerking genoten. Jouw enthousiaste inbreng en creativiteit zijn van onschatbare waarde voor het eindresultaat. Ik heb echt veel van je geleerd! Ook het samen verzorgen van onderwijs was erg prettig. Spontaan komt ook het weekje in Grenoble bij me op, waar het uiteindelijk toch wel erg gezellig was, ondanks dat EXAFS niet gauw mijn favoriete bezigheid zal worden...

Jan, ik waardeer jouw bijdrage aan dit onderzoek heel erg. Jouw positieve kijk op onderzoeksvragen en kennis op allerlei gebieden waren zeer waardevol en hebben tot leuke discussies en gesprekken geleid.

Tymen, bedankt voor de uitstekende en zeer prettige samenwerking en de mooie resultaten die je op jouw deel van het onderzoek hebt neergezet. Voor mijn gevoel vulden we elkaar uitstekend aan en hebben we echt iets moois van dit onderzoek gemaakt. Het gaf een heel sterk gevoel om bij presentaties en conferenties als duo op te treden en samen ons onderzoek te vertegenwoordigen. Verder denk ik ook met plezier terug aan de gezellige avonden op meetings en cursussen. Mijn dank gaat ook 
naar je begeleiders Hans en Martin, voor hun bijdrage en de aangename en productieve samenwerking.

Dennis, ik wil je graag bedanken voor de uitstekende prestaties tijdens je afstuderen en de prettige samenwerking gedurende het laatste jaar. Ik weet zeker dat je de komende 4 jaar succesvol aan je promotie zal werken! Jordi, thanks for your contribution to my work. It is not described in this thesis but it gave very valuable information!

Lianne, uiteraard bedankt voor de secretariële ondersteuning, maar veel belangrijker ook bedankt voor het steeds klaar staan voor gesprekken over allerlei andere dingen, het helpen met van alles en nog wat en voor jouw gezellige inbreng in het dagelijks leven in onze groep en daarbuiten!

Bert, naast de uitstekende technische ondersteuning ook mijn dank voor de gezellige tijd tijdens koffiepauzes, borrels, beurzen en andere festiviteiten. Ook jij was van enorm belang voor de gezelligheid in de groep! Verder kom ik ook steeds op je hulp en adviezen rekenen bij allerlei vragen betreffende klusjes aan de auto, het huis, de fiets en andere kwesties in het leven.

Seshan, hartelijk bedankt voor alle hulp en discussies en je inbreng en begeleiding op water gas shift en op het gebied van wateractivering.

Jeroen, het was erg prettig om je bijna 3 jaar als collega te hebben. Bedankt voor de technische hulp en de hele fijne tijd! Hans, bedankt voor de 4 aangename jaren samen bij CPM, alle cursussen en conferenties waar we ons altijd uitstekend vermaakt hebben en ik met jou steeds een aangename kamergenoot had. Karin en Louise, bedankt voor alle ondersteuning op het lab en analyses van mijn samples.

A special thanks to my officemates during the 4 years for the nice time and talks we had together: Sune, Sergio, Miriam and Son. I would like to thank all present and former group members and colleagues for the nice time that we had during coffee breaks, lunches, dinners, courses, conferences, excursions, parties, soccer matches, Zhu, Jiang, Nabeel, Valer, Khalid, Dejan, Daryl, Igor (still remember our great victory of the NIOK cup), Berta (I always enjoyed your enthusiastic and outgoing personality), Iris (schitterende discussies, waren we het ooit ergens over eens?:)), 
Cristiano (really like our friendship), Davide (our great defender, liked our dinners at Antica Villa), Vijay, Gacia, Hrudya, Marijana, Kazu, Kumar (what a great week we had in Korea!), all other (exchange) students, all other members of our CPM soccer team.

Martin Pijl van Varian, Gerard Wiecherink en Frans Arts van Bronkhorst en Huub Raterink van Brooks bedank ik voor de zeer prettige samenwerking en de gezellige borrels op de Instrumenten beurs.

Mark, Herman, Marinus, Ivo, Bas, Willem, Danny, Patricia, Elke, bedankt voor de etentjes, squashpartijen, stapavonden, weekendjes weg, enz.. de ontzettend gezellige tijd hier in Enschede, die wat mij betreft nog even doorgaat! Alle leden van ons zaalvoetbal team in Enschede!

Maurice, Koen, Raimond, Olaf, Rudi, Cyriel, Wouter, Hans, Hennie, Toonen, Jim en alle andere "Limburgers" die mij ontzettend mooie en gezellige weekenden hebben opgeleverd bij en rond de tafeltennisclub Kluis en op allerlei andere plekken zoals Eindhoven, Enschede, Warschau, Düsseldorf, enz. Een speciale dank ook aan Lia en Jos voor alle gezelligheid en ondersteuning.

Daniel en Inge, bedankt voor alle steun die ik van jullie heb gehad en alle andere leuke dingen die we samen hebben ondernomen.

Papa, Renate und Oma, ich moechte mich bei Euch fuer die Unterstuetzung waehrend der Promotion bedanken und ich bin immer gerne zu Besuch bei Euch!

Mam, ik waardeer heel erg dat jij er altijd voor me stond en me steeds ondersteund hebt! Het voelde heel prettig om in Beek steeds "thuis" te komen tijdens vakanties en weekenden. 



\section{Publications}

P.O. Graf, B.L. Mojet, J.G. van Ommen, and L. Lefferts, Comparative study of steam reforming of methane, ethane and ethylene on $\mathrm{Pt}, \mathrm{Rh}$ and $\mathrm{Pd}$ supported on yttriumstabilized zirconia, Applied Catalysis A: General 332 (2007) 310-317

P.O. Graf, B.L. Mojet, and L. Lefferts, Influence of potassium on the competition between methane and ethane in steam reforming over Pt supported on yttriumstabilized zirconia, Applied Catalysis A: General 346 (2008) 90-95.

P.O. Graf and L. Lefferts, Reactive separation of ethylene from the effluent gas of methane oxidative coupling via alkylation of benzene to ethylbenzene onZSM-5, submitted to Chemical Engineering Science

P.O. Graf, B.L. Mojet and L. Lefferts, The effect of potassium addition to $\mathrm{Pt}$ supported on YSZ on steam reforming of mixtures of methane and ethane, Applied Catalysis A: General in preparation

P.O. Graf, D.J.M. de Vlieger, B.L. Mojet, L. Lefferts, New insights in the water gas shift mechanism on $\mathrm{Pt} / \mathrm{ZrO}_{2}$ : the role of hydroxyl groups elucidated, submitted to Journal of Catalysis 


\section{Posters \& Presentations}

Patrick Graf, Tymen Tiemersma, Martin van Sint Annaland, Barbara Mojet, Hans Kuipers \& Leon Lefferts, Simultaneous production of ethylene and synthesis gas: combining coupling and reforming of methane, Oral presentation at Netherlands Process Technology Symposium (NPS), 2007

Patrick Graf, Barbara Mojet \& Leon Lefferts, Influence of potassium on Pt-catalysts in steam reforming of ethane and methane, Oral presentation at Netherlands' Catalysis and Chemistry Conference (NCCC), 2007

Patrick Graf, Barbara Mojet and Leon Lefferts, Influence of potassium on Pt-catalysts in steam reforming of methane \& ethane, Poster Presentation at 14th International Catalysis Congress, July 13-18 2008, Seoul Korea

Patrick Graf: Poster presentations at Netherlands Catalysis and Chemistry Conference (NCCC 2006 and 2008) 


\section{Curriculum Vitae}

Patrick Graf werd op 19 augustus 1979 geboren in Aachen (Duitsland). Na bezoeken van basisschool de Stutensee (Duitsland) verhuisde hij met zijn moeder en broertje naar Beek in Nederland en bezocht het gymnasium St Michiel in Geleen. Na het behalen van het diploma in 1998 begon hij met de opleiding Chemische technologie aan de TU Eindhoven. De bedrijfsstage bij Roche in Basel (Zwitserland) en het afstudeerproject bij de vakgroep Chemical Reactor Engineering waren de belangrijkste studieonderdelen. De studie werd in 2003 afgerond, waarna Patrick nog aan zijn afstudeerproject verder werkte als toegevoegd onderzoeker. Op 1 september 2004 begon Patrick aan zijn promotieonderzoek in de vakgroep Catalytic Processes and Materials aan de Universiteit Twente. De belangrijkste resultaten van dit onderzoek staan beschreven in dit proefschrift. Vanaf 15 oktober 2008 werkt Patrick als Basic Design Engineer bij Zeton BV in Enschede. 


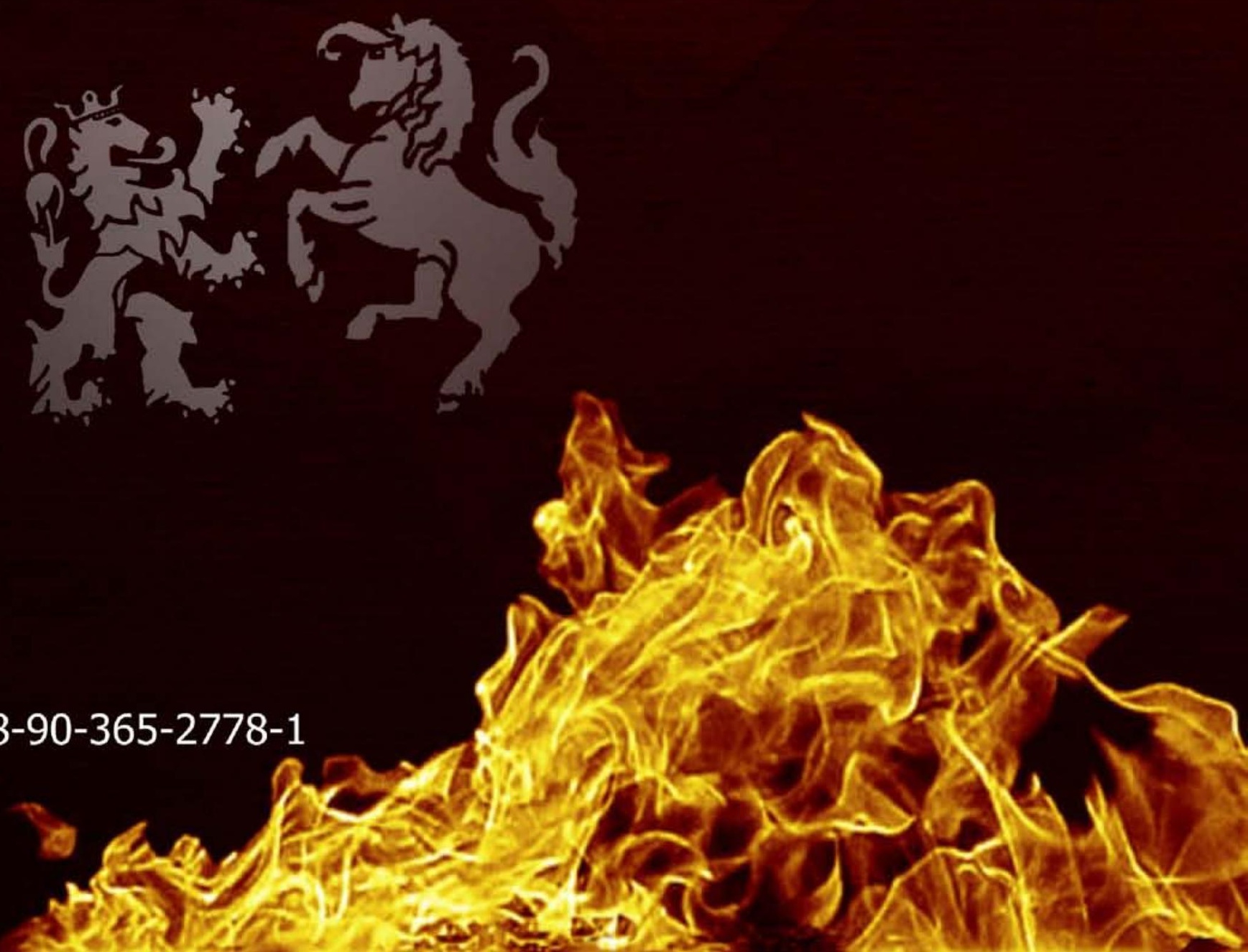

ISBN: 978-90-365-2778-1 